\title{
De diagnostiek van gebroken vliezen
}

Citation for published version (APA):

Offermans, J. P. M. (1991). De diagnostiek van gebroken vliezen. [Doctoral Thesis, Maastricht University]. Datawyse / Universitaire Pers Maastricht. https://doi.org/10.26481/dis.19911018jo

Document status and date:

Published: 01/01/1991

DOI:

10.26481/dis.19911018jo

Document Version:

Publisher's PDF, also known as Version of record

\section{Please check the document version of this publication:}

- A submitted manuscript is the version of the article upon submission and before peer-review. There can be important differences between the submitted version and the official published version of record.

People interested in the research are advised to contact the author for the final version of the publication, or visit the DOI to the publisher's website.

- The final author version and the galley proof are versions of the publication after peer review.

- The final published version features the final layout of the paper including the volume, issue and page numbers.

Link to publication

\footnotetext{
General rights rights.

- You may freely distribute the URL identifying the publication in the public portal. please follow below link for the End User Agreement:

www.umlib.nl/taverne-license

Take down policy

If you believe that this document breaches copyright please contact us at:

repository@maastrichtuniversity.nl

providing details and we will investigate your claim.
}

Copyright and moral rights for the publications made accessible in the public portal are retained by the authors and/or other copyright owners and it is a condition of accessing publications that users recognise and abide by the legal requirements associated with these

- Users may download and print one copy of any publication from the public portal for the purpose of private study or research.

- You may not further distribute the material or use it for any profit-making activity or commercial gain

If the publication is distributed under the terms of Article $25 \mathrm{fa}$ of the Dutch Copyright Act, indicated by the "Taverne" license above, 
De diagnostiek van gebroken vliezen 


\section{DE DIAGNOSTIEK VAN GEBROKEN VLIEZEN}

PROEFSCHRIFT

ter verkrijging van de graad van doctor aan de Rijksuniversiteit Limburg te Maastricht op gezag van de Rector Magnificus, Prof. Mr. M.J. Cohen, volgens het besluit van het College van Dekanen, in het openbaar te verdedigen op vrijdag 18 oktober 1991 om 14.00 uur

door

Joseph Paul Marie Offermans

geboren te Amstenrade in 1951 
Promotores: $\quad$ Prof. Dr. J. de Haan

Prof. Dr. P.J. Brombacher

Co-promotores: Dr. L.A. Schellekens

Dr. F. Smits

Beoordelingscommissie: Prof. Dr. J.P.M. Geraedts (voorzitter)

Prof. Dr. I.A. Brosens

Prof. Dr. C.E. Blanco

Prof. Dr. T.K.A.B. Eskes

Prof. Dr. J.A. Knottnerus

CIP-GEGEVENS KONINKLIJKE BIBLIOTHEEK, DEN HAAG

Offermans, Joseph Paul Marie

De diagnostiek van gebroken vliezen /

Joseph Paul Marie Offermans.

- Maastricht: Universitaire Pers. - Ill.

Proefschrift Maastricht. - Met lit. opg.

ISBN 90-5278-013-7

NUGI 742

Trefw.: verloskunde.

Typografische adviezen: G. van Rooy

Druk: Reprografie R.L. 
Aan Yvonne

Thijs

Bart

Mijn ouders 


\section{Inhoudsopgave}

Voorwoord 13

Vraagstelling en opzet van het onderzoek 15

$\begin{array}{lll}1.1 & 15\end{array}$

$\begin{array}{lll}1.2 & \text { Vraagstelling } & 16\end{array}$

$\begin{array}{lll}1.3 & \text { Opzet van het onderzoek } & 17\end{array}$

- Samenstelling van de groepen en de periode waarin het onderzoek plaatsvond 17

- Gouden standaard 18

- Statistische bewerking $\quad 19$

Algemeen literatuuroverzicht $\quad 21$

$\begin{array}{lll}2.1 & 21\end{array}$

$\begin{array}{lll}2.2 & \text { Etiologie van het voortijdig breken van de vliezen } & 21\end{array}$

$2.3 \quad$ Incidentie van voortijdig gebroken vliezen 26

2.4 Complicaties van voortijdig gebroken vliezen 27

$2.5 \quad$ Literatuuroverzicht van diagnostische mogelijkheden 32

- Subjectieve methode $\quad 35$

- Objectieve methoden $\quad 35$

- Invasieve methoden $\quad 40$

- Overige methoden $\quad 40$

- Nieuwe methoden $\quad 43$

De enquête

het onderzoek 45

45

Resultaten van de enquête 46

- Incidentie van twijfel aan het gebroken zijn van de vliezen 46

- Pariteit, leeftijd en amenorroeduur in de enquêtegroep 46

- Klachten van de patienten in de enquêtegroep 47

- Onderzock dat werd verricht in de enquêtegroep 48

Nederlandse gegevens over langdurig gebroken vliezen 53

$4.1 \quad$ Inleiding 53

4.2 Opzet van het onderzoek 53

$\begin{array}{ll}4.3 & \text { Unsluitcriteria voor dit deel van het onderzoek }\end{array}$

- Incidentie van voortijdig gebroken vliezen $\quad 56$

- Duur van het gebroken zijn van de vliezen $\quad 58$

- Leeftijd van de moeder 61

- Langdurig gebroken vliezen en de zwangerschapsduur 61

- De duur van het gebroken zijn van de vliezen en de relatie met pariteit en

amenorrhoeduur $\quad 63$

- Voorafgaande manipulaties aan de cervix uteri 66

- Inleiding van de baring $\quad 67$

- Liggingsafwijkingen 68

- Kunstverlossingen 69

- Geslacht van de geboren kinderen $\quad 69$

- Geboortegewichten $\quad 70$ 
inhoudsopgave

- Neonatale morbiditeit $\quad 71$

- Perinatale mortaliteit $\quad 73$

- Morbiditeit en mortaliteit van de moeder $\quad 73$

Nadelen van twijfel aan het gebroken zijn van de vliezen

$\begin{array}{lll}5.1 & \text { Inleiding } & 77\end{array}$

$\begin{array}{llr}5.2 & \text { Opzet van het onderzoek } & 77\end{array}$

$\begin{array}{lll}5.3 & \text { Resultaten van het onderzoek } & 78\end{array}$

- Kenmerken van de groep met dubieus gebroken vliezen waarbij vocht
werd verzameld

- Vergelijking van de groep met kortdurend gebroken vliezen (S.I.G.), dubieus gebroken vliezen samen met de enquêtegroep (eigen onderzoek) en de groep met $\begin{array}{ll}\text { langer dan } 24 \text { uur gebroken vliezen (S.I.G.) } & 79\end{array}$

- Vroeggeboorten $\quad 80$

- Liggingsafwijkingen $\quad 81$

- Kunstverlossingen $\quad 82$

- Dysmaturiteit $\quad 83$

- Neonatale morbiditeit $\quad 84$

- Perinatale mortaliteit $\quad 85$

- Morbiditeit van de moeder $\quad 86$

Resultaten van bepalingsmethoden bij drie groepen patiënten: waarbij de vliezen zeker gebroken, zeker niet gebroken en niet zeker waren gebroken

6.1

6.2

Inleiding

Opzet van het onderzoek

- grop met zeker staande of gebroken vliezen $\quad 89$

- De groep met een onzekere diagnose

Resultaten van het onderzoek 95

- Eiwitbepaling

$\begin{array}{lr}\text { Varentest } & 97\end{array}$

- Inleiding $\quad 97$

- Uitvoering van de varentest 98

- Eigen resultaten 98

- Resultaten van de varentest in de groep patiënten met een zekcre diagnose 99

- Resultaten van de varentest in de groep patienten met dubieus gebroken vliezen 101

6.5 Opnamefrequentie na het verrichten van de varentest bij dubieus gebroken vliezen 103

$\begin{array}{ll}\text { pH-Bepaling } & 106\end{array}$

$\begin{array}{ll}\text { - Inleiding } & 106\end{array}$

- pH-Bepaling bij patiënten met een zekere diagnose 107

- pH-Bepaling bij patiènten met dubieus gebroken vliezen $\quad 109$

\begin{tabular}{ll}
6.6 & 112 \\
\hline & Nile-blue-sulfaat-test
\end{tabular}

- Inleiding $\quad 112$

- Methode van de Nile-blue-sulfaat-kleuring $\quad 112$

- Nile-blue-sulfaat-kleuring bij patiěnten met een zekere diagnose 112

- Nile-blue-sulfaat-kleuring bij patiënten met dubieus gebroken vliezen 115

$\begin{array}{lll}6.7 & \text { Prolactinebepaling } & 118\end{array}$

$\begin{array}{ll}\text { - Inleiding } & 118\end{array}$

- Bepalingsmethode van prolactine $\quad 120$

- Calibratie van de prolactinebepaling $\quad 121$

- Prolacunebepaling bij patiènten met cen zekere diagnose $\quad 124$ 
- Het vergroten van de betrouwbaarheid van de prolactinebepaling bij dubieus gebroken vliezen

- Prolactinebepaling bij patienten met dubieus gebroken vliezen 130

- Inleiding

- Bepalingsmethode van kreatinine

- Kreatininebepaling bij patiěnten met een zekere diagnose

- Kreatininebepaling bij patiënten met dubieus gebroken vliezen $\quad 137$

Diamine-oxidase-activiteit

- Inleiding

- Bepalingsmethode van DAO-activiteit

- DAO-activiteit bij patiénten met een zekere diagnose

- DAO-activiteit bij patiěnten met dubieus gebroken vliezen 145

- Inleiding

- Bepalingsmethode van AFP

- AFP-bepaling bij patienten met een zekere diagnose

- AFP-bepaling bij patiertten met dubieus gebroken vliezen 151

6.11 Humaan Chorion Gonadotrophine 153

- Inleiding 153

- Bepalingsmethode van hCG 154

- HCG-bepaling bij patienten met een zekere diagnose 155

- Het vaststellen van afkappunten voor het berekenen van de sensitiviteit en specificiteit bij de hCG-bepaling

- HCG-bepaling bij patienten met dubieus gebroken vliezen 158

$\begin{array}{lll}6.12 & \text { Humaan Placental Lactogen } & 160\end{array}$

- Inleiding 160

- Bepalingsmethode van hPL 161

- HPL-bepaling bij patienten met cen zekere diagnose 162

- HPL-bepaling bij patienten met dubieus gebroken vliezen 164

$\begin{array}{lll}6.13 & \text { Glucose- en fructose-bepaling } & 167\end{array}$

$\begin{array}{ll}\text { - Inleiding } & 167\end{array}$

- Methode van glucose- en fructose-bepaling 168

- Glucose-bepaling bij patiënten met een zekere diagnose 168

- Glucose-bepaling bij patiënten met dubieus gebroken vliezen 171

- Fructose-bepaling bij patienten met een zekere diagnose 173

- Fructose-bepaling bij patiënten met dubieus gebroken vliezen 176

- Combinatie van de glucose- en fructosebepaling 177

$\begin{array}{ll}\text { Combinaties van bepalingsmethoden } & 179\end{array}$

$\begin{array}{ll}\text { Algemene discussie } & 181\end{array}$

$\begin{array}{ll}\text { Samenvatting } & 183\end{array}$

$\begin{array}{ll}\text { Summary } & 187\end{array}$

$\begin{array}{ll}\text { Literatuur } & 191\end{array}$

$\begin{array}{ll}\text { Bijlagen } & 209\end{array}$ 


\section{Voorwoord}

Het in dit proefschrift beschreven onderzoek werd uitgevoerd tijdens mijn opleiding tot gynaecoloog in drie opleidingsklinieken: het academisch ziekenhuis te Maastricht, het De Wever-Ziekenhuis te Heerlen en de Sint Elisabeth Kliniek te Heerlen. Het onderzoek werd voor een belangrijk deel bekostigd door het Praeventiefonds te Den Haag.

Het zal duidelijk zijn dat indien een onderzoek in drie klinieken wordt uitgevoerd velen aan het onderzoek hebben meegewerkt en het is derhalve onmogelijk om op deze plaats eenieder te noemen die een (vruchtwater)steentje aan het onderzoek heeft bijgedragen. Daarom wil ik beginnen met iedereen te danken die ik hier niet kan noemen voor de bijdrage die werd geleverd aan het slagen van dit onderzoek.

Speciale dank ben ik verschuldigd aan (in chronologische volgorde):

Dr. F. Roumen, gynaecoloog. Geachte Frans, het protocol van dit onderzoek ontsproot aan jouw brein. Door je positieve instelling kwam het onderzoek van de grond en kreeg ik de mogelijkheid om te worden opgeleid tot gynaecoloog.

Dr. L. Schellekens, gynaecoloog. Geachte Louis, de beminnelijke manier en de nooit aflatende zelfverzekerdheid waarmee je de mensen van het Praeventiefonds toesprak, hebben de realisatie van het onderzoek bewerkstelligd. Ook na je vertrek uit Heerlen belde je regelmatig op om me aan te sporen het onderzoek af te ronden. Prof. Dr. J. de Haan, gynaecoloog en Prof. Dr. P. Brombacher, klinisch chemicus, zorgden door kritische en deskundige opmerkingen voor de wetenschappelijke onderbouwing.

Dr. F. Smits, gynaecoloog. Frans, zonder jouw hulp was dit proefschrift nooit afgekomen. Het is jouw verdienste dat een berg onmogelijk geformuleerde tekst werd omgevormd tot dit proefschrift. Soms boos, soms vertwijfeld, maar ook af en toe niet begrijpend hoe iemand zoiets kon schrijven, ging jij door met corrigeren.

Dr. H. Schouten, statisticus. Geachte Hubert, gaarne wil ik je danken voor de waardevolle adviezen die werden gegeven met betrekking tot de opzet en de statistische onderbouwing van het onderzoek.

Het gezamenlijke personeel van de verloskamers en de poliklinieken van de drie deelnemende ziekenhuizen ben ik dankbaar voor het verzamelen van vruchtwater en andere benodigde vloeistoffen.

Ook alle gynaecologen, assistenten en verloskundigen die vocht verzamelden ben ik dank verschuldigd.

Het isotopenlaboratorium en het klinisch chemisch laboratorium van het De WeverZiekenhuis in casu Harrie Janssen en Jo Marell, produceerden op accurate wijze de uitslagen. Assistentie werd verleend door Cock Bank, die de diamine-oxidasebepalingen uitvoerde en José Martens, die de varentests en de Nile-blue-sulfaattests op diafilm vastlegde.

Mevrouw A. Gerritsen, verloskundige. Geachte Agnes, zowel bij het opstarten als 
voorwoord

bij het uitwerken van het onderzoek was jij in de St. Elisabeth Kliniek mijn steun en toeverlaat.

Dr. L. Peeters, gynaecoloog. Geachte Louis, bij problemen van wetenschappelijke aard was jij steeds bereid mee te denken, waarvoor dank.

Drs. H. de Haan, arts-assistent. Geachte Harm, de varentest was voor jou een uitdaging. Eenvoudig maar zeer doeltreffend toonde jij aan, dat de varentest bij twijfel aan het gebroken zijn van de vliezen geen optimale test is.

Drs. C. de Die-Smulders, klinisch geneticus. Geachte Christine, zonder morren maar uiterst fanatiek haalde jij vele typefouten uit elk concept-manuscript, dat je steeds werd aangeboden als de definitieve versie.

De heer $H$. Wetzelaer. Geachte Harrie, bij problemen die met computers of computerprogramma's te maken hadden wist jij steeds dé oplossing.

De beoordelingscommissie bestaande uit Prof. Dr. J. Geraedts, Prof. Dr. I. Brosens, Prof. Dr. C. Blanco, Prof. Dr. T. Eskes en Prof. Dr. A. Knottnerus wil ik bedanken voor de tijd die ze aan dit proefschrift hebben besteed en voor de waardevolle adviezen die werden gegeven.

Mijn vader en de heer G. van Rooy. Geachte $\mathrm{Pa}$, geachte Guus, jullie wisten de tekst, die op een eenvoudige wijze was opgemaakt, te voorzien van een uitstekende lay-out. Ook aan jullie heel veel dank voor de prettige en deskundige hulp.

Yvonne, Thijs en Bart hartelijk dank voor de vrijheid die jullie me gaven; meer tijd zal voor jullie in de toekomst worden uitgetrokken.

Ook wil ik mijn vrienden en kennissen danken voor het krediet dat ik kreeg; hopelijk breken betere tijden aan.

Tenslotte dank ik nogmaals allen die, op welke wijze dan ook, hulp en steun hebben verleend om dit werk te kunnen voltooien. 


\section{Hoofdstuk 1}

\section{Vraagstelling en opzet van het onderzoek}

\subsection{Inleiding}

Weliswaar gaat aan de geboorte van de meeste kinderen het breken van de vliezen vooraf. Toch is dit breken van de vliezen niet altijd zonder risico's. Deze risico's, voor moeder en/of kind, kunnen het gevolg zijn van het langdurig gebroken zijn of het voortijdig breken van de vliezen. Helaas is het niet steeds eenvoudig om het gebroken zijn van de vliezen met zekerheid aan te tonen. Met name doet dit probleem zich voor als slechts kleine hoeveelheden vocht verzameld kunnen worden. Bovendien zal uit literatuur en eigen onderzoek blijken dat verbetering van de beschikbare diagnostiek zeer gewenst is.

Het stellen van de diagnose: "gebroken vliezen zonder weeënactiviteit" heeft ingrijpende consequenties voor moeder en kind. Als de zwangerschap 37 weken overschrijdt, wordt de baring doorgaans op gang gebracht; is de zwangerschapsduur minder dan 34 weken, dan wordt in de regel getracht de baring uit te stellen. In de tussenliggende periode van 34 tot 37 weken zal de beslissing om de baring in te leiden of de weeënactiviteit te onderdrukken van vele factoren afhankelijk zijn. Voor de patiënte betekent dit in veel gevallen hospitalisatie en van belang is dan ook het stellen van de juiste diagnose.

Het is van belang te weten hoe vaak de diagnose voortijdig gebroken vliezen buiten (paragraaf 2.3) en binnen (hoofdstuk 4.3.1) Nederland wordt gesteld.

In de zestiger en zeventiger jaren werd veel onderzoek verricht op het gebied van de diagnostiek van het gebroken zijn van de vliezen. In de tachtiger jaren werd meer aandacht besteed aan het te voeren beleid bij gebroken vliezen, waarbij verschillende vormen van behandeling werden vergeleken (Fayez e.a. 1978, Varner en Galask 1981, Berkowitz e.a. 1982, Wilson e.a. 1982, Perkins 1982, Duff 1984).

Deze verschuiving in de belangstelling, van diagnostiek naar behandeling, zou er op kunnen duiden dat de diagnostiek geen probleem meer is. Nadere bestudering van de literatuur leert het tegendeel: om de diagnose te stellen worden tests gebruikt waarvan in het verleden (Lange Friedman en McElin 1969) al is geconstateerd dat de betrouwbaarheid niet altijd hoog is (sensitiviteit en specificiteit tussen 73,0 en 97,7\%). Soms gaat de auteur zelfs in het geheel niet in op de betrouwbaarheid van de methoden ter bevestiging van de diagnose (Mead 1980).

In voornoemde studies over de behandeling van gebroken vliezen zullen door de niet geheel betrouwbare diagnostiek van gebroken vliezen ook patiënten aanwezig zijn geweest die geen gebroken vliezen hadden. 
hoofdstuk 1

Het is tegen deze achtergrond van belang methoden te ontwikkelen, die de diagnose "gebroken vliezen" met meer zekerheid kunnen doen stellen of verwerpen (hoofdstuk 6); slechts door enkele onderzoekers werd dit onderkend (Smith 1976, Gibbs en Blanco 1982, Reece e.a. 1984, Feinstein e.a. 1986).

Nieuwe technieken werden ontwikkeld op biochemisch en histologisch gebied. Zelfs werd een intra-amniotische injectie met kleurstof gepropageerd (Atlay en Sutherst 1970, Smith 1976, Cotton e.a. 1984). Hoewel doorgaans de amniocentese wordt beschreven als een ingreep met een te verwaarlozen kans op complicaties (Fairweather 1978), werd in de literatuur ook melding gemaakt van emstige complicaties (Goodlin en Clewell 1974, Gottdiener e.a. 1975, Young e.a. 1977, Hasaart en Essed 1983). De amniocentese bij mogelijk gebroken vliezen blijkt, ook na introductie van de echoscopie, niet zonder gevaar te zijn.

De klinische chemie heeft nieuwe methoden ontwikkeld waarmee het mogelijk werd in zeer kleine hoeveelheden vocht bepalingen uit te voeren en betrouwbare uitslagen te verkrijgen. Toch, zo stellen een aantal auteurs (Smith 1976, Gibbs en Blanco 1982, Reece e.a. 1984 en Feinstein e.a. 1986), heeft elke methode nog steeds een niet te verwaarlozen aantal fout-positieve en fout-negatieve resultaten; dit zal zeker bij een hoge vliesscheur gelden.

Uit de beschikbare literatuuroverzichten (Lange Friedman en Mc Elin 1969, Gunn e.a. 1970) blijkt dat er weliswaar sprake is van toegenomen inzicht omtrent oorzaken en gevolgen van het breken van de vliezen, maar het stellen van de diagnose "gebroken vliezen" levert nog steeds problemen op.

\subsection{Vraagstelling}

De vraagstelling van dit onderzoek is drieledig:

1. Hoe vaak wordt aan de diagnose gebroken vliezen getwijfeld?

In de bestaande literatuur wordt vermeld dat de diagnose gebroken vliezen niet altijd eenvoudig is te stellen (paragraaf 1.1). Maar er is geen literatuur voorhanden die beschrijft hoe vaak men twijfelt aan het gebroken zijn van de vliezen.

2. Zijn aan die twijfel nadelen verbonden?

De morbiditeit en mortaliteit bij langdurig gebroken vliezen werd in het verleden uitvoerig beschreven (paragraaf 2.4). Maar er zijn geen gegevens bekend als men twijfelde aan het gebroken zijn van de vliezen. 
3. Hoe kan die twijfel worden voorkomen?

Als vaak wordt getwijfeld en als dit twijfelen nadelige gevolgen heeft dan is de vraag gerechtvaardigd hoe dit twijfelen kan worden voorkomen. Het antwoord zal een bepalingsmethode zijn die betrouwbaar (hoge sensitiviteit en specificiteit), die noch invasief noch kostbaar is en toepasbaar in elk ziekenhuis.

\subsection{Opzet van het onderzoek}

\subsubsection{Samenstelling van de groepen en de periode waarin het onderzoek plaatsvond}

Om de eerste vraag (frequentie van twijfelen) te beantwoorden werd een enquête gehouden in drie ziekenhuizen in de periode van 01-01-1985 tot 01-01-1986. Wanneer een zwangere patiënte zich meldde bij de afdeling obstetrie van het academisch ziekenhuis Maastricht, het De Wever-Ziekenhuis te Heerlen of de Sint Elisabeth Kliniek te Heerlen en er werd getwijfeld aan het gebroken zijn van de vliezen, dan werd een registratieformulier ingevuld. In het totaal werden 166 registratieformulieren ontvangen (de enquête-groep). De resultaten van de enquête zijn beschreven in hoofdstuk 3.

Om de betekenis van de frequentie van de morbiditeit en mortaliteit in de "twijfelgroep" te kunnen beoordelen (vraagstelling 2), werden enerzijds gegevens verzameld van groepen patiënten met wel en niet langdurig gebroken vliezen in Nederland, anderzijds van patiënten met dubieus gebroken vliezen, in de drie deelnemende klinieken, de "twijfelgroep" (hoofdstuk 4 en 5). Te verwachten is dat de morbiditeit en mortaliteit die optreedt in de "twijfelgroep" ligt tussen de groep met wel en niet langdurig gebroken vliezen.

Ter beantwoording van de tweede vraagstelling werd de medewerking verkregen van de Stichting Informatiecentrum voor de Gezondheidszorg (S.I.G.). De S.I.G. heeft gegevens van een groot gedeelte van de baringen die in ziekenhuizen in Nederland plaatsvinden. Bewerkt werden 3870 registraties van patiënten met langer dan 24 uur gebroken vliezen en 3799 registraties van patiënten met korter of gelijk aan 24 uur gebroken vliezen, bevallen in de periode van 01-01-1985 tot 01-01-1986. Niet alleen werden deze twee groepen vergeleken, ook werden deze S.I.G.-gegevens vergeleken met de klinische gegevens van patiënten van de drie deelnemende klinieken die waren bevallen nadat in de zwangerschap was getwijfeld aan het gebroken zijn van de vliezen. 
hoofdstuk 1

De groep patiënten waarbij tijdens de zwangerschap werd getwijfeld aan het gebroken zijn van de vliezen bestond uit twee sub-groepen: de eerder genoemde enquête-groep en een groep met dubieus gebroken vliezen. De groep met dubieus gebroken vliezen bestond uit patiënten waarbij tijdens de zwangerschap werd getwijfeld aan het gebroken zijn van de vliezen en waarbij vocht werd verzameld in de klinieken die deelnamen aan het onderzoek van 01-01-1986 tot 01-07-1986. In deze laatste groep werd vocht verzameld om de diagnose gebroken vliezen aan te tonen. De enquête-groep bestond uit 166 patiënten; de groep met dubieus gebroken vliezen uit 120 patiënten. De gehele groep waarbij aan het gebroken zijn van de vliezen werd getwijfeld bestond dus uit 286 patiënten.

Aan het eigenlijke onderzoek ter beantwoording van de derde vraag ging een pilot study vooraf (1983). Het doel van deze pilot study was het onderzoeken van de praktische uitvoerbaarheid van de verschillende tests om gebroken vliezen aan te tonen. In deze pilot study werd bij 93 patiënten met staande vliezen vocht uit de vagina verzameld. Ook werd bij 51 patiënten met zeker gebroken vliezen vruchtwater en urine afgenomen. In de verkregen monsters werden een aantal tests verricht. De resultaten, voor zover van belang, zijn beschreven in hoofdstuk 6 .

Op het derde gedeelte van de vraagstelling werd getracht een antwoord te vinden door bij 203 patiënten, bij wie de diagnose staande dan wel gebroken vliezen zeker was, vocht te verzamelen. In het vocht (vruchtwater, serum, urine, fluor vaginalis en cervixslijm) werden een aantal bepalingen uitgevoerd. Ook werden deze bepalingen uitgevoerd in het semen van 5 fertiele mannen.

De resultaten van de bepalingen, verkregen in het vocht bij de groep met een bekende diagnose, werden vergeleken met de resultaten van de bepalingen in het vocht, verkregen in de groep met dubieus gebroken vliezen. Ook deze resultaten worden vermeld in hoofdstuk 6 .

De samenstelling van bovengenoemde groepen in de periode waarin het onderzoek plaatsvond en het aantal patiënten per groep is vermeld in bijlage 1 .

\subsubsection{Gouden standaard}

De diagnose staande dan wel gebroken vliezen kon in de groep met dubieus gebroken vliezen retrospectief met zekerheid worden gesteld door bestudering van de beschikbare patiëntengegevens. Dat wil zeggen dat op grond van klinische parameters eerst na afloop van de baring werd besloten dat op het moment van het dubieuze vruchtwaterverlies de vliezen stonden of waren gebroken. 
De diagnose gebroken vliezen werd zeker geacht indien:

- na de eerste symptomen van gebroken vliezen de patiënte min of meer continu én onwillekeurig vochtverlies hield

- bij het eerste vaginale toucher, na het optreden van de eerste symptomen, geen vliezen werden gevoeld.

De diagnose staande vliezen werd zeker geacht indien:

- na de eerste klacht van de patiënte de zwangerschap minstens 4 weken ongeén compliceerd verliep, zonder onwillekeurig vochtverlies

- bij het eerste vaginale toucher, na het optreden van de klacht, vliezen werden gevoeld.

Indien ook retrospectief niet besloten kon worden of de vliezen, op het moment van de klacht, waren gebroken, dan werden deze patiënten niet opgenomen in dit onderzoek.

\subsubsection{Statistische bewerking}

Bij de statistische bewerkingen werd, tenzij anders vermeld, gebruik gemaakt van de chi-kwadraattoets. Als significantiegrens werd gehanteerd $p<0,05$.

De bruikbaarheid van de verschillende technieken om gebroken vliezen aan te tonen werd geëvalueerd middels de Receiver Operating Characteristic (ROC) methode.

Bij combinatie van de verschillende technieken om gebroken vliezen aan te tonen werd gebruik gemaakt van een logistisch regressie-model (statistische pakket B.M.D.P.).

\section{Discussie}

Indien een zwangere patiënte continu, onwillekeurig, grote hoeveelheden waterig en niet bloederig vocht verliest uit de cervix uteri, dan zullen de vliezen wel gebroken zijn. In zo'n situatie is de diagnose gebroken vliezen eenvoudig met behulp van een speculum zonder verdere hulpmiddelen te stellen. Indien wordt getwijfeld aan het gebroken zijn van de vliezen, is de diagnostiek van het aantonen van vruchtwaterverlies van belang. Dit onderzoek richt zich dan ook voornamelijk op deze patiënten met "dubieus gebroken vliezen", de nadelen die het gevolg zijn van een onjuiste diagnose 
hoofdstuk 1

en de meest geschikte methode om wel tot een diagnose te komen.

In de literatuur is geen enkele methode bekend waarvan wordt aangenomen dat de betrouwbaarheid $100 \%$ is. Zelfs niet als de veiligheid voor de patiënte en haar foetus buiten beschouwing wordt gelaten. Om de diagnostiek van gebroken vliezen toch te kunnen bestuderen werd een retrospectieve "gouden standaard" gedefinieerd waarbij de diagnose aan de hand van klinische parameters werd gesteld. Indien het stellen van de werkelijke diagnose, wel of niet gebroken vliezen, ook retrospectief niet mogelijk was, werden de resultaten van de bepalingen bij die patiënten niet gebruikt. 


\section{Hoofdstuk 2}

\section{Algemeen literatuuroverzicht}

\subsection{Inleiding}

In dit algemeen literatuuroverzicht wordt aangesloten bij de drieledige vraagstelling van dit onderzoek. Daarbij komen de uit de literatuur bekende incidentie van voortijdig gebroken vliezen aan de orde, de nadelen van voortijdig gebroken vliezen en tenslotte een overzicht van de bepalingsmethoden. Deze bepalingsmethoden worden meer in detail, inclusief de geschiedenis ervan, beschreven in samenhang met de resultaten van deze bepalingsmethoden in dit onderzoek (hoofdstuk 6).

Hoewel in strikte zin geen deel uitmakend van dit onderzoek, wordt in dit literatuuroverzicht begonnen met de mogelijke oorzaken van gebroken vliezen. Dit is ook interessant omdat in dit onderzoek een groot aantal patiëntengegevens werden verzameld die het mogelijk zouden kunnen maken een risicogroep aan te wijzen.

\subsection{Etiologie van het voortijdig breken van de vliezen}

Uit de literatuur blijkt dat uiteenlopende oorzaken worden aangegeven voor het breken van de vliezen en dat geen overeenstemming bestaat over dé oorzaak.

Retrospectief bleken weliswaar in bepaalde onderzoekgroepen patiënten met een bepaalde "afwijking" vaker voortijdig gebroken vliezen te hebben, maar het causale verband kon meestal niet worden aangetoond.

De mogelijke oorzaken van het voortijdig breken van de vliezen kunnen schematisch worden verdeeld in:

\section{A. Cervicale oorzaken}

Door chirurgische manipulatie aan de cervix voor of tijdens de zwangerschap is er meer kans op voortijdig gebroken vliezen (Evaldson e.a. 1980, Naeye 1982). Als voorbeelden zijn te noemen: een curettage waarbij de cervix wordt gedilateerd, biopsieën en cerclages. De pathofysiologische achtergrond is niet bekend.

Ook zou cervixinsufficiëntie een rol kunnen spelen (Polishuk e.a. 1964, Eggers e.a. 1979), eventueel in combinatie met meerlingzwangerschap of polyhydramnion. 
hoofdstuk 2

B. Oorzaken gelegen in de vliezen zelf

- Niet-genetisch bepaalde zwakte van de vliezen

Doordat bij het vorderen van de zwangerschap een gedeelte van de cervix wordt opgenomen in het onderste uterussegment neemt de trekkracht op de vliezen toe. Meudt en Meudt (1967) veronderstelden, op grond van microscopisch onderzoek, dat sprake was van een gelei tussen het amnion en het chorion. Indien deze gelei waterig genoeg was dan zou het chorion over het amnion heen kunnen schuiven. Was dat niet het geval, dan braken de vliezen. Door andere onderzoekers (Artal e.a. 1976) werd een verschil in dikte van de vliezen gevonden op de plaats waar de vliezen gebroken waren, ten opzichte van de dikte van de vliezen naast de placenta. Deze onderzoekers vonden ook naast de placenta een lagere elasticteitsmodulus (gedefinieerd als de helling van de curve waarin tegen elkaar is uitgezet de belasting, in gram, tegen de vormverandering, in centimeter, en aldus de stijfheid weergevend) in vergelijking tot de plaats waar de vliezen waren gebroken. Er zijn onderzoekers die de conclusies van Artal e.a. (1976) bevestigden (Parry-Jones en Priya 1976) en anderen die deze conclusies meenden te kunnen weerleggen (Polishuk e.a. 1962, 1964). Weer andere onderzoekers (Al Zaid e.a. 1980) meldden dat de druk die nodig was om vliezen in vitro te breken, bij een groep waarbij de vliezen tijdens de zwangerschap spontaan waren gebroken tussen de 30 en 38 week amenorroe, groter was dan bij een groep waarbij de vliezen spontaan à terme waren gebroken. De druk die nodig was om vliezen in vitro te breken bij een groep waarbij de vliezen artificieel gebroken waren à terme, was groter dan de druk die nodig was bij de groep à terme waarbij de vliezen spontaan waren gebroken. De druk die in vitro nodig was à terme, bij de groep waarbij de vliezen artificieel waren gebroken, was wel lager dan de druk die nodig was om de vliezen in vitro te breken bij de groep met prematuur gebroken vliezen.

Al-Zaid e.a. (1980) vonden geen significant verschil in het aantal collagene vezels dat werd aangetroffen in de vliezen bij de premature groep en de à terme groep. Dit werd door andere onderzoekers bevestigd (Evaldson e.a. 1987). Al Zaid e.a. (1980) concludeerden dat mogelijk een lokaal defect de oorzaak was voor het prematuur breken van de vliezen. De oorzaak van dit defect was mogelijk de aan- of afwezigheid van een enzym (Artal e.a. 1979) of de aanwezigheid van een infectie (Naeye 1979, Sbarra e.a. 1987).

\section{- Genetisch bepaalde zwakte van de vliezen}

Bij erfelijke afwijkingen waarbij collageen niet adequaat wordt aangelegd, zoals bij familiair abnormaal sterke beweeglijkheid van de gewrichten (Thornton e.a. 1988) en het syndroom van Ehlers-Danlos (Blom 1983, Rudd e.a. 1983, Levick 1989) werden verhoogde frequenties van voortijdig gebroken vliezen waargenomen. Daar het echter kleine groepen patiënten betreft is een definitieve conclusie niet verantwoord. 


\section{Vruchtwaterhoeveelheid}

Op theoretische basis is het voorstelbaar dat bij een grote hoeveelheid vruchtwater, polyhydramnion, de druk langzaam toeneemt en op de plaats van de minste weerstand de vliezen breken. Mogelijk is in deze situatie ook sprake van een extra verkorting van de cervix.

Bovendien zouden de vliezen door het toegenomen volume dunner kunnen worden en daardoor voortijdig breken.

\section{Foetale oorzaken}

Het is voorstelbaar dat ook de foetus een actieve rol kan spelen in het proces van het voortijdig breken van de vliezen. Zo was meconium in staat om de vliezen weker te maken in vitro (Meudt en Meudt 1967). Ook werd een verband gelegd tussen het voortijdig breken van de vliezen en de ligging van de foetus (Calkins 1952, Kjessler 1956). Daar in de onderzoeksgroep van laatstgenoemde onderzoekers een groot aantal patiënten voorkwam met een amenorroeduur van minder dan 37 weken, is het de vraag of de toegenomen frequentie van een afwijkende ligging oorzaak of gevolg is; immers de ligging van de foetus vroeg in de zwangerschap is minder stabiel.

Het geslacht van de foetus was van invloed op het voortijdig breken van de vliezen (Seki en Kato 1987). Deze onderzoekers constateerden dat het voortijdig breken van de vliezen frequenter voorkwam indien de foetus van het mannelijke geslacht was (ratio $=1,4$ ). Een verklaring voor dit verschil konden Seki en Kato (1987) niet geven.

\section{E. Intravaginale manipulatie}

Het ontraden van de coïtus tijdens de zwangerschap werd in Nederlandse leerboeken voor obstetrie lang gepropageerd (van der Hoeven 1924, ten Berge 1967). Deze auteurs suggereerden een verband tussen de coïtus en het optreden van een abortus, vaginaal bloedverlies, het voortijdig breken van de vliezen en het ontstaan van endometritis in het kraambed. Later verscheen literatuur waarin men rechtstreeks verband legt tussen de coïtus en het voortijdig breken van de vliezen (Naeye 1979, 1981, Naeye en Ross 1982). De oorzaak zou niet gelegen zijn in het optreden van contracties (Wagner e.a. 1976) of in enzymactiviteit van semen (Lavory en Miller 1981), maar chorioamnionitis kwam bij vrouwen, die seksueel actief waren tijdens de zwangerschap, vaker voor dan bij vrouwen die niet seksueel actief waren tijdens de zwangerschap (Naeye en Ross 1982). Niet alle onderzoekers waren deze laatst genoemde mening toegedaan (Mills en Harlap 1981).

Niet alleen infecties konden de kans op het breken van de vliezen verhogen. Ook de prostaglandinespiegel steeg na intravaginaal manipuleren, zoals bij het gynaecologische onderzoek gebeurt (Mitchell e.a. 1977), terwijl bij het in partu komen een stijging van de prostaglandines werd waargenomen in het vruchtwater (Keirse e.a. 1977). 
hoofdstuk 2

Ook werd een verband gelegd tussen frequent gynaecologisch onderzoek en het breken van de vliezen (Lenihan 1984).

\section{F. Lokale ontsteking}

In de vagina kwam een commensale flora voor die indrukwekkend was wat de verscheidenheid betreft (Larsen 1979). Bij lokale of systemische weerstandsvermindering is het mogelijk dat een bepaalde bacteriestam de overhand krijgt. In de patiëntengroep waarbij de vliezen voortijdig braken kwam een hogere kolonisatiegraad voor (Naeye en Peters 1980 en Creatsas e.a. 1981). Mogelijk speelden hierbij pathogene microorganismen, zoals chlamidia trachomatis en de B-haemolytische streptococ een rol (Blackmore e.a. 1986, Alger e.a. 1988). Ook bij de neonatus, van deze groep zwangeren, werden immunologische veranderingen waargenomen die zo snel na het breken van de vliezen aantoonbaar waren dat een infectie al intrauterien moet hebben bestaan voordat de vliezen braken (Cederqvist e.a. 1979).

Ook zou de baring in gang gezet kunnen worden door verhoogde produktie van phospholipase $A_{2}$ door aanwezige bacteriestammen. Het phospholipase $A_{2}$ kan archidonzure esters vrij maken uit phospholipiden en daardoor de prostaglandinesynthese bevorderen (Bejar e.a. 1981, Evers 1982, Lamont e.a. 1985, Romero e.a. 1986, Lopez Bernal e.a. 1987a, Lopez Bernal e.a. 1987b).

\section{G. Deficiëntie}

Lokale weerstandsvermindering zou veroorzaakt kunnen worden door een systemisch tekort aan bepaalde stoffen. Koper, een metalloenzym, speelt een rol bij de rijping van collageen en elastine. Hoewel koperdeficiëntie zeldzaam is werden er bij patiënten met voortijdig gebroken vliezen significant lagere waarden aangetroffen (Artal e.a. 1979). Ook is de invloed van vitamine $C$ bestudeerd (Wideman e.a. 1964). Bij patiënten met een verlaagde plasmaconcentratie en een verminderde opname van vitamine $C$ constateerde men vaker voortijdig gebroken vliezen. Het voortijdig breken van de vliezen kwam vaker voor in lagere socio-economische delen van de bevolking (Naeye 1979); er waren onderzoekers die zich afvroegen of het verband dat werd gevonden tussen bijvoorbeeld de concentratie van vitamine $\mathrm{C}$ in het plasma en het voortijdig breken van de vliezen hetzelfde was, als het verband tussen dieet of roken en de socio-economische status (Meyer en Tonascia 1977, Naeye 1979).

\section{H. Invloed van prolactine}

De rol van prolactine tijdens de zwangerschap is niet geheel begrepen maar heeft in ieder geval te maken met osmolaliteit, volumeregulatie en electrolytenconcentratie van en in vruchtwater (Ron e.a. 1982, de Bakker 1986). 
Er zijn aanwijzingen dat de prolactineconcentratie in vliezen die voortijdig gebroken zijn, hoger is dan de prolactineconcentratie in vliezen die niet voortijdig gebroken zijn (Ron e.a. 1982).

\section{Barometrische invloeden}

In enige publikaties werd een verband gezocht tussen luchtdrukinvloeden en de frequentie van het voorkomen van voortijdig gebroken vliezen (Millingos e.a. 1978, Marks e.a. 1983, Polansky e.a. 1985). De bevindingen zijn tegenstrijdig. Zo vonden Polansky e.a. (1985) wel een verband tussen het dalen van de luchtdruk en het voortijdig breken van de vliezen, maar konden zij het "omgekeerde" niet bevestigen.

\section{J. Leeftijd van de moeder}

Enkele onderzoekers vonden een verband tussen de leeftijd van de moeder en het voortijdig breken van de vliezen (Gunn e.a. 1970). Op hogere leeftijd zouden de vliezen vaker voortijdig breken. Het hieraan ten grondslag liggende patho-fysiologische mechanisme was mogelijk de pariteit.

K. Invloed van de pariteit

Het voortijdig breken van de vliezen zou gecorreleerd zijn aan het toenemen van de pariteit (Gunn e.a. 1970 en Neaye 1982). Mogelijk is dit fenomeen te verklaren met een cervixfactor. Bij multiparae is de cervix door een fysiologisch proces "opgerekt" bij de vorige baring(en). Bij multiparae wordt doorgaans enige ontsluiting van de cervix gevonden (na de $24^{c}$ week van de zwangerschap). Hierdoor kan de bescherming van de vliezen tegen opstijgende infecties minder zijn bij multiparae.

\section{Conclusies}

1. Het is aannemelijk dat het voortijdig breken van de vliezen multifactorieel wordt bepaald. Hierbij spelen lokale ontsteking, intravaginale manipulaties, deficiëntie, genetische factoren, maternale oorzaken en zelfs weersveranderingen mogelijk een rol.

2. Doordat vele oorzaken een rol kunnen spelen bij het voortijdig breken van de vliezen - en de bijdrage van de afzonderlijke oorzaken niet bekend is - zijn risicogroepen niet aan te geven. 
hoofdstuk 2

2.3 Incidentie van voortijdig gebroken vliezen

Meerdere auteurs geven de incidentie van voortijdig gebroken vliezen verschillend op (tabel 1).

Tabel 1: Incidentie van het voortijdig breken van de vliezen.

\begin{tabular}{lcrr}
\hline & Jaar & $\begin{array}{r}\text { Aantal } \\
\text { patiënten }\end{array}$ & $\begin{array}{r}\text { Incidentie } \\
(\%)\end{array}$ \\
\cline { 2 - 3 } Auteur & & & \\
Calkins & 1952 & & \\
Clark en Anderson & 1964 & 7.243 & 15.2 \\
Lanier e.a. & 1965 & 32.022 & 3,2 \\
Sacks en Baker & 1967 & 7.637 & 6.2 \\
Gunn e.a. & 1970 & 6.269 & 6.6 \\
Bada e.a. & 1977 & 17.562 & 10.7 \\
Evaldson e.a. & 1980 & 19.420 & 4.6 \\
Daikoku e.a. & 1982 & 3.391 & 0.9 \\
Lenihan & 1984 & 2.812 & 23,4 \\
& & 254 & 12,0 \\
\hline
\end{tabular}

De oorzaak van deze verschillen moet worden gezocht in de weinig éénduidige definitie van voortijdig gebroken vliezen. Het voortijdig breken van de vliezen (door de meeste onderzoekers P.R.O.M. genoemd, Premature Rupture Of the Membranes) wordt gedefinieerd als het breken van de vliezen voordat weeënactiviteit optreedt. Nagenoeg alle beschikbare literatuur gaat voorbij aan het rekbare begrip weeënactiviteit. Weeënactiviteit treedt niet plotseling op maar ontstaat geleidelijk en is moeilijk, zonder extra risico's (intra-uteriene drukmeting), te objectiveren. De term P.R.O.M. doet vermoeden dat er een bepaalde amenorroeduur aan is verbonden. Echter de ene onderzoeker laat zich daar niet over uit, terwijl de andere dat nauwkeurig maar niet identiek aan anderen definieert. Ook het aantal uren dat maximaal "mag" verstrijken totdat de weeënactiviteit op gang komt varieert in de definitie van 0 uur tot meer dan 24 uur (Jones e.a. 1975).

Wanneer alleen die literatuurgegevens in beschouwing worden genomen die én grote groepen patiënten omvatten, zonder beperking van de duur tussen breken van de vliezen en weeënactiviteit én, die iedere zwangerschapsduur in het onderzoek opnemen, dan wordt door de meeste onderzoekers een incidentie opgegeven van circa $10 \%$ (Webb 1967, Gunn e.a. 1970, Mead 1980 ). P.R.O.M. is dus een vaak voorkomend probleem. 
literatuuroverzicht

\subsection{Complicaties van voortijdig gebroken vliezen}

De problemen die zich kunnen voordoen zijn:
A. infecties bij moeder en/of kind
B. het ontijdig op gang komen van de baring
C. het optreden van liggingsafwijkingen en het uitzakken van kleine delen of navelstreng
D. het ontstaan van deformaties en/of longhypoplasie bij de foetus.

Dat de consequenties van het voortijdig breken van de vliezen erg groot kunnen zijn bleek uit een onderzoek van Naeye uit 1977. Hij analyseerde 53.518 zwangerschappen. Bij 1 op de 10 gevallen van perinatale sterfte in deze groep was er een relatie met het voortijdig breken van de vliezen.

De ernst van de problemen die zich voordeden was afhankelijk van de duur van de zwangerschap. De complicaties van het voortijdig breken van de vliezen worden derhalve, in de volgende paragraaf, besproken per zwangerschapsduur: de immature periode ( 16 tot 28 weken), de premature periode ( 28 tot 37 weken) en de mature periode ( 37 tot 42 weken).

\section{A. Infecties}

Evenals de literatuur over de incidentie van P.R.O.M. is de literatuur die verschenen is over het voorkomen van infecties bij voortijdig gebroken vliezen nauwelijks onderling vergelijkbaar. De gebruikte criteria, die als bewijs werden gebruikt dat intra-uterien een infectie was opgetreden, liepen zeer uiteen: kweekuitslagen, de aanwezigheid van bacteriën in het vruchtwater (Ledger 1979), histologisch onderzoek van de placenta en vliezen (Naeye en Peters 1980), temperatuurverhoging bij de moeder (Gunn e.a. 1970) en foetale veranderingen (Bada e.a. 1977, Creatsas e.a. 1981).

Hoewel de definities van intra-uteriene infectie verschilden, waren er toch gemeenschappelijke opvattingen (Mead 1980):

1. Verschillende auteurs (Lanier e.a. 1965, Gunn e.a. 1970, Bada e.a. 1977, Miller e.a. 1978, Johnson e.a. 1981) vermeldden een relatie tussen de frequentie van het optreden van intra-uteriene infecties en het tijdsinterval tussen het breken van de vliezen en het begin van weeënactiviteit (de latente periode). Hoe langer de latente periode was, des te meer kans op een intra-uteriene infectie en daardoor zou ook het risico op perinatale sterfte toenemen. Dit laatste werd niet door iedereen onderschreven: sommigen (Johnson e.a. 1981) vonden wel een stijging, maar de gevonden verschillen waren statistisch niet significant. 
hoofdstuk 2

2. Ook de amenorroeduur zou bij het ontstaan van een intra-uteriene infectie een rol spelen. Naeye en Peters gaven in 1980 een overzicht (tabel 2).

Tabel 2: Overzicht van het ontstaan van intra-uteriene infecties naar lengte van de latente periode en zwangerschapsduur (Naeye en Pelers 1980).

\section{patiènten met intra-uteriene infecties per zwangerschapsduur (in weken)}

20-28

(\%)
$29-32$

(\%)
33-37

(\%)

duur gebroken vliezen

$\begin{array}{rlll}\text { afwezig } & 23 & 15 & 11 \\ 1 \text { tot en met } 4 \text { uur } & 48 & 29 & 32 \\ 5 \text { tot en met } 12 \text { uur } & 50 & 25 & 21 \\ 13 \text { tot en met } 24 \text { uur } & 44 & 30 & 28 \\ >24 \text { uur } & 68 & 58 & 44\end{array}$

Door de twee boven beschreven factoren (latente periode en amenorroe) wordt de foetus, indien de vliezen breken voor de $36^{\circ}$ week, meer bedreigd door een intra-uteriene infectie dan wanneer de vliezen breken na de $36^{\circ}$ week.

De genoemde percentages in tabel 2 zijn door andere onderzoekers bevestigd (Kappy e.a. 1979, Johnson e.a. 1981). Ook werd aangegeven dat de frequentie van een intra-uteriene infectie na een sectio ceasarea hoger was dan na een spontane baring (Kappy e.a. 1979, Ledger 1979, Johnson e.a. 1981). Het betrof steeds menginfecties en anaërobe bacteriën werden in $70 \%$ van de gevallen aangetroffen (Ledger 1979). Het optreden van een intra-uteriene infectie zou samenhangen met het aantal malen dat inwendig onderzoek werd verricht (Schutte 1981), waarbij het geen verschil zou maken of er vaginaal of rectaal werd getoucheerd (Maudsley e.a. 1966).

Niet alleen de foetus maar ook de moeder liep gevaar om geïnfecteerd te worden (endometritis). De kans daarop was het grootst als zij beviel bij een amenorroeduur van minder dan 37 weken (Daikoku e.a. 1982). Deze onderzoekers vonden een verhoogde frequentie van het optreden van endometritis bij een latente periode van meer dan 24 uur.

Een intra-uteriene infectie is ook nu nog steeds een van de oorzaken van maternale sterfte (Webb 1967, Gibbs en Locke 1976, Daikoku e.a. 1982). Ondanks het beschikbaar zijn van adequate antibiotica is het behandelen van een intra-uteriene infectie ook post partum nog steeds niet eenvoudig (Koh e.a. 1979). 
B. Het ontijdig op gang komen van de baring

De kans om in partu te komen na het vroegtijdig breken van de vliezen is gerelateerd aan de amenorroeduur (Sacks en Baker 1967).

Ook de lengte van de latente periode is afhankelijk van de amenorroeduur. De kans om snel spontaan in partu te komen stijgt met het toenemen van de amenorroeduur (figuur 1). Er zijn ook raciale invloeden gevonden op het ontijdig breken van de vliezen en mogelijk eveneens geografische verschillen (Lanier e.a. 1965 en Johnson e.a. 1981).

Figuur 1: De kans om binnen 24 uur in partu te komen bij gebroken vliezen per amenorroegroep (naar Sacks en Baker 1967).

De kans in partu te raken binnen 24 uur

Bij gebroken vliezen

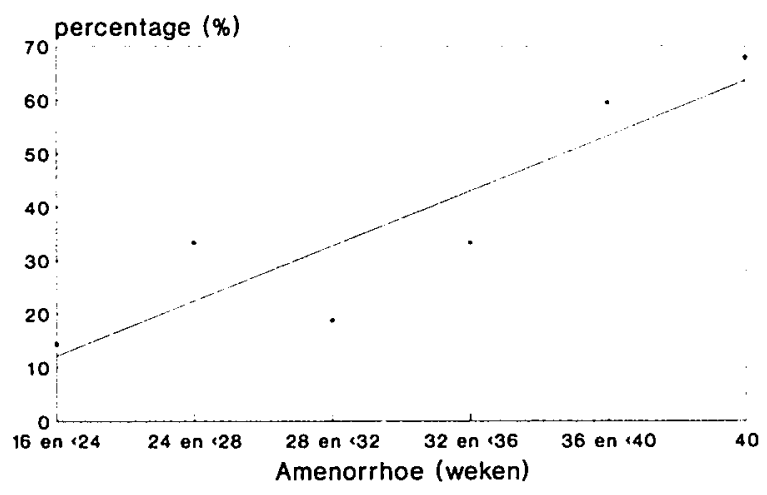

Wanneer de baring op gang komt in het premature tijdperk wordt de foetus bedreigd door een aantal aandoeningen die te maken hebben met onrijpheid.

De meest voorkomende complicatie is het optreden van het Respiratory Distress Syndrome (R.D.S.), vroeger ook wel Hyaliene Membraan Ziekte (H.M.Z.) genoemd. Het optreden van R.D.S. is veruit de belangrijkste oorzaak van morbiditeit en mortaliteit bij het prematuur geboren kind. Andere problemen die kunnen ontstaan zijn: intracerebrale bloedingen en necrotiserende enterocolitis. Deze laatste twee complicaties van onrijpheid van de vrucht worden mogelijk tevens veroorzaakt door het tijdens de baring ontstaan van hypoxie (Quirk e.a. 1979, Nochimson e.a. 1980). 
Hoewel een belangrijke bedreiging voor het te vroeg geboren kind R.D.S. is, zijn er aanwijzingen dat de duur van het gebroken zijn van de vliezen negatief gecorreleerd is met het ontstaan van deze longaandoening. Er zijn onderzoekers die bij langdurig gebroken vliezen de incidentie van R.D.S. niet zagen afnemen (Jones e.a. 1975, Bada e.a. 1977, Kappy e.a. 1979), maar toch werd door dezen in dit opzicht een positief effect van langdurig gebroken vliezen geconstateerd voor de $34^{\mathrm{c}}$ week van de zwangerschap (Yoon en Harper 1973, Richardson e.a. 1974, Bauer e.a. 1974, Sell en Harris 1977, Miller e.a. 1978, Berkowitz e.a. 1978). De versnelde longrijping van kinderen, geboren na langdurig gebroken vliezen, hoeft echter niet het gevolg te zijn van het langdurig gebroken zijn van de vliezen. Factoren die eerder in de zwangerschap een rol hebben gespeeld, mogelijk ook bij het breken van de vliezen, zouden evenzeer aan deze versnelde longrijping hebben kunnen bijdragen (Worthington e.a. 1977). Voorbeelden hiervan zijn: groeivertraging, vaginaal bloedverlies, hypertensie en diabetes mellitus. De literatuur over het voorkomen van R.D.S. bij langdurig gebroken vliezen is niet eensluidend en soms tegenstrijdig. $\mathrm{Na}$ de $28^{e}$ week van de zwangerschap werd vrijwel steeds een stijging van de L/S-ratio (als maat voor de longrijpheid) gevonden (Gluck en Kulovich 1973, Richardson e.a. 1974, Merkus 1974, Berkowitz e.a. 1978, Obladen e.a. 1979, Schutte 1981). In deze publikaties werd echter geen duidelijke afname van de R.D.S.-frequentie beschreven. Deze negatieve bevinding zou verklaard kunnen worden door de samenstelling van de groepen. Vergeleken werden groepen met korter en langer dan 24 uur gebroken vliezen (Jones e.a. 1975), terwijl de versnelde longrijping al binnen 6 uur te constateren was (Richardson e.a. 1974). Ook het gebruik van corticosteroiden zou de resultaten beïnvloed hebben (Papageorgiou 1981 e.a.) evenals het effect van een traumatische baring (Quirk e.a. 1979).

In een ander onderzoek (Berkowitz e.a. 1978) vond men weliswaar een lagere frequentie van R.D.S. bij langdurig gebroken vliezen, maar geen afname van de mortaliteit in de groep met een amenorroeduur van minder dan 33 weken.

Het lijkt waarschijnlijk dat het voortijdig breken van de vliezen de longrijping versnelt: bij een amenorroeduur van 30 tot 34 weken trad, na langdurig gebroken vliezen, R.D.S. slechts op bij 30 procent van de kinderen (Richardson e.a. 1974, Berkowitz e.a. 1978, Papageorgiou e.a. 1981 ) terwijl een percentage van 50 tot $60 \%$ werd gevonden indien een prematuur geboren werd na niet langdurig gebroken vliezen (Schutte 1981).

Een bijkomend probleem bij het effect op de longrijping is de mogelijkheid dat voortijdig gebroken vliezen vaker voorkomen indien de foetus van het mannelijke geslacht is (Seki en Kato 1987). Daar R.D.S. vaker bij jongens dan bij meisjes voorkwam die prematuur werden geboren (Collaborative group on antenatal steroid therapy 1981, Papageorgiou e.a. 1981) is de kans op morbiditeit groter; met name in de groep jongens die prematuur wordt geboren. 
C. Het voorkomen van liggingsafwijkingen en uitzakken van kleine delen of de navelstreng

De incidentie van voortijdig gebroken vliezen wordt veelal opgegeven als $10 \%$ van het totaal aantal baringen (tabel 1). De frequentie van het voortijdig breken van de vliezen voor de $36^{\mathrm{e}}$ week is: $0,9 \%$ (10\% van de patiënten bevallen in de premature periode) van het totaal aantal baringen (Evaldson e.a. 1980). Ook in het verdere verleden werd al gevonden dat de patiëntengroep met gebroken vliezen voor de $37^{c}$ week een vijfde tot een tiende deel uitmaakt van de hele populatie met voortijdig gebroken vliezen (Ekvall e.a. 1961, Lebherz e.a. 1961, Burchell 1964). Voor de $36^{\circ}$ week is de ligging van het kind vaak instabiel: het voorliggende deel is meestal niet ingedaald. Navelstreng en/of ledematen zullen in deze groep relatief vaak uitzakken. In absolute zin is het probleem minder grout omdat veel minder kinderen prematuur worden geboren dan matuur. In tabel 3 zijn literatuurgegevens samengevat voor de twee meest voorkomende problemen in dit opzicht: dwarsligging en uitgezakte navelstreng.

Tabel 3: Overzicht van de frequentie van dwarsligging of uitgezakte navelstreng bij voortijdig gebroken viezen.

\begin{tabular}{rrrrr} 
& Jaar & $\begin{array}{r}\text { Aantal } \\
\text { patiënten }\end{array}$ & $\begin{array}{r}\text { Dwars- } \\
\text { ligging } \\
(\%)\end{array}$ & $\begin{array}{r}\text { Navel- } \\
\text { streng } \\
(\%)\end{array}$ \\
\cline { 2 - 5 } auteur & & & \\
Ekvall e.a. & 1961 & & & \\
Lebherz e.a. & 1961 & 363 & 0.3 & 0.3 \\
Lebherz e.a. & 1961 & 945 & 0.1 & 0.7 \\
Lanier e.a. & 1965 & 3155 & - & 0.7 \\
Sacks en Baker & 1967 & 473 & 0.6 & 0,4 \\
Gunn e.a. & 1970 & 415 & 0.5 & 1,7 \\
Christensen e.a. & 1976 & 1884 & - & 0.8 \\
Miller e.a. & 1978 & 24 & 4,2 & 4,2 \\
Kappy & 1979 & 151 & 2.7 & 2.0 \\
& & 188 & 0.5 & 0,5 \\
\hline
\end{tabular}

Concluderend kan worden gesteld dat dwarsligging ten tijde van het breken van de vliezen en het uitzakken van de navelstreng voorkomt bij minder dan één procent van de zwangeren waarbij de vliezen voortijdig breken.

D. Het ontstaan van deformaties en/of longhypoplasie

Indien een conservatief beleid werd voorgestaan bij het voortijdig breken van de vliezen, werd melding gemaakt van een licht verhoogd aantal afwijkingen bij de foetus (Varner en Galask 1981, Wilson e.a. 1982 en Widjaja 1984). 
hoofdstuk 2

Kinderen kunnen door intrauteriene compressie van de zich ontwikkelende longen post partum overlijden ten gevolge van longhypoplasie (Wilson e.a. 1982). Ook werden kinderen beschreven met afwijkingen aan de extremiteiten na langdurig gebroken vliezen (bijvoorbeeld klompvoeten). Indien de vliezen zeer vroeg breken, voor de $16^{c}$ week, kunnen ernstige afwijkingen voorkomen (buik- en borstwanddefecten, craniofaciale afwijkingen). Deze ernstige afwijkingen worden mogelijk veroorzaakt door amnionstrengen die een disruptie van de normale morphogenese veroorzaken. Deze ernstige afwijkingen werden gevonden bij 1:25.000 partus à terme (Higginbottom e.a. 1979 en Miller 1981).

\section{Conclusies}

1. Wanneer de vliezen breken tussen de $16^{\mathrm{c}}$ en $28^{\mathrm{e}}$ week van de zwangerschap wordt de foetus na de baring bedreigd door zijn onrijpheid. Het R.D.S.-percentage in deze periode is zeer hoog. De baring komt vaak niet op gang. Een intra-uteriene infectie dreigt. Er bestaat verder vaak een afwijkende ligging. Door een lange periode van gebroken vliezen is de kans op deformaties en/of longhypoplasie reëel.

2. Bij het breken van de vliezen tussen de $28^{c}$ en $37^{\circ}$ week van de zwangerschap wordt de foetus bedreigd door het optreden van een intra-uteriene infectie; post partum is de kans op het Respiratory Distress Syndrome aanzienlijk. Na de $34^{\circ}$ week neemt de kans op het ontstaan van R.D.S. sterk af.

3. Na 37 weken amenorroeduur is het optreden van een infectie bij de foetus de meest voorkomende complicatie. Andere complicaties zijn van ondergeschikt belang.

4. Bij voortijdig gebroken vliezen loopt de moeder een verhoogde kans op een endometritis, met name indien de vliezen breken voor de $37^{\mathrm{c}}$ week.

\subsection{Literatuuroverzicht van diagnostische mogelijkheden}

In dit overzicht komt alleen het algemene literatuuroverzicht aan de orde. De specifieke literatuur betreffende de testmethoden is vermeld bij de beschrijving daarvan (hoofdstuk 6).

Vele methoden worden beschreven om de diagnose gebroken vliezen aan te tonen. In grote lijnen worden de volgende methoden onderscheiden (tabel 4): 
Tabel 4: De methoden die in de literatuur beschreven worden en de methoden die zouden kunnen worden gebruikt om de diagnose gebroken vliezen aan te tonen.

Subjectieve methode

- anamnese

Objectieve methoden

- fysische methoden

- cytologische methoden

- chemische methoden

Invasieve methoden

- amniocentese

- onderzoek in speculo

Overige, "theoretische" methoden

- subjectieve methoden

- objectieve methoden

- invasieve methoden

Hoewel in met name de oudere literatuur de betrouwbaarheid veelal niet werd berekend is deze, in de zin van sensitiviteit en specificiteit, voor zover mogelijk zelf berekend.

De resultaten aldus uitgedrukt lopen nogal uiteen (tabel 5). 
hoofdstuk 2

Tabel S: De sensitiviteit en specificireil van de verschillende methoden ter detectie van vruchtwaterverlies zoals berekend uil literatuurgegevens.

\begin{tabular}{|c|c|c|c|c|}
\hline & $\begin{array}{r}\text { aantal } \\
\text { patiënten }\end{array}$ & $\begin{array}{r}\text { sensiti- } \\
\text { tiviteit } \\
(\%)\end{array}$ & $\begin{array}{r}\text { specifi- } \\
\text { citeit } \\
(\%)\end{array}$ & bron \\
\hline \multicolumn{5}{|l|}{ methoden } \\
\hline anamnese & 100 & 90,3 & 88,4 & $\begin{array}{l}\text { Lange Friedman } \\
\text { en McElin } 1969\end{array}$ \\
\hline \multirow[t]{2}{*}{ varentest } & 150 & 73,3 & 88,0 & Langreder 1958 \\
\hline & 509 & 98,7 & 98,1 & Smith 1976 \\
\hline test van Iannetta & 37 & 100,0 & 100,0 & Iannetta 1984 \\
\hline lanugoharen & 65 & 1,5 & - & Volet en Morier 1960 \\
\hline \multirow[t]{2}{*}{ foetale vetcellen } & 65 & 70,8 & 90,2 & Volet en Morier 1960 \\
\hline & 280 & 97,2 & 99,7 & von Numers 1936 \\
\hline \multirow[t]{2}{*}{ vernix caseosa } & 100 & 97,1 & 80,3 & $\begin{array}{l}\text { Lange Friedman en } \\
\text { McElin } 1969\end{array}$ \\
\hline & 111 & 100,0 & 98,2 & $\begin{array}{l}\text { Brosens en } \\
\text { Gordon } 1965\end{array}$ \\
\hline \multirow[t]{2}{*}{ foetale huidcellen } & 130 & 50,0 & 95,0 & Langreder 1958 \\
\hline & 250 & 98,2 & 95,2 & Gall en Spellacy 1964 \\
\hline \multirow[t]{3}{*}{ diamine-oxidase-activiteit } & 65 & 87,0 & 84,0 & Schumacher e.a. 1976 \\
\hline & 272 & 100,0 & 100,0 & Elmfors e.a. 1974 \\
\hline & 146 & 100,0 & 94,0 & Wishart e.a. 1979 \\
\hline \multirow[t]{2}{*}{$\alpha$-foctoproteïne } & 201 & 83.8 & 92,0 & Rochelson c.a. 1987 \\
\hline & 48 & 97,9 & 100,0 & Rochelson e.a. 1987 \\
\hline glucose & 215 & 82,9 & 100,0 & Gorodeski e.a. 1979 \\
\hline fructose & 215 & 80,5 & 50,0 & Gorodeski e.a. 1979 \\
\hline \multicolumn{5}{|l|}{3.32 log glucose +} \\
\hline \multicolumn{5}{|l|}{ humaan Placental } \\
\hline Lactogen & 52 & laag & laag & Huber e.a. 1983 \\
\hline \multirow[t]{2}{*}{ prolactine } & 52 & laag & laag & Huber e.a. 1983 \\
\hline & 20 & 100,0 & 100,0 & Koninckx e.a. 1981 \\
\hline \multirow[t]{3}{*}{$\mathrm{pH}$} & 304 & 78,2 & 98,5 & Volet en Morier 1960 \\
\hline & 319 & 100,0 & 96,7 & Gold 1927 \\
\hline & 100 & 90.3 & 82,6 & $\begin{array}{l}\text { Lange Friedman } \\
\text { en McElin } 1969\end{array}$ \\
\hline $\begin{array}{l}\text { methylcenblauw } \\
\text { /amnionpunctie }\end{array}$ & 18 & 100,0 & 100,0 & $\begin{array}{l}\text { Atlay en } \\
\text { Sutherst } 1970\end{array}$ \\
\hline
\end{tabular}


Wanneer men de geschiedenis van de verschillende bepalingen beziet, dan zijn trends te ontdekken. Tot 1950 is door allerlei onderzoekers wetenschappelijk werk verricht om de betrouwbaarheid te toetsen van de pH-bepaling en cytologische methoden. Tijdens de vijftiger en zestiger jaren werden de fysische methoden aan het scala van mogelijkheden toegevoegd. Gedurende de zeventiger en tachtiger jaren werden vooral de chemische en invasieve methoden gebruikt.

\subsubsection{Subjectieve methode}

- De anamnese

De anamnese van patiënte is, bij het stellen van de diagnose gebroken vliezen, niet weg te denken (Lange Friedman en McElin 1969). Door het verhaal van de patiënte rijst de verdenking dat de vliezen mogelijk gebroken zijn. Omdat dit niet meer dan een verdenking kan zijn moet onderzoek uitgevoerd worden dat de diagnose aantoont dan wel verwerpt.

\subsubsection{Objectieve methoden}

A. Fysische methoden

- Varentest

De meest bekende fysische methode om vruchtwater aan te tonen is de varentest. Toch werd de varentest aanvankelijk niet gebruikt om vruchtwater aan te tonen. De test werd voor het eerst beschreven voor het beoordelen van cervixslijm. Wanneer cervixslijm op een objectglas wordt gebracht en aan de lucht wordt gedroogd, dan ontstaan zoutkristallen. Deze kristallen lijken op varens, wanneer het glaasje onder de microscoop wordt bekeken met een vergroting van 100x (Papanicolaou 1946).

Een voorbeeld van de varentest laat figuur 2 zien.

Later werd duidelijk dat dit fenomeen niet specifiek was voor cervixslijm (Zondek en Rozin 1954, Kovacs 1962, Kroeks 1976). Vruchtwater en vele andere lichaamsvloeistoffen hebben het vermogen om varens te vormen.

Aangetoond werd dat de varens worden gevormd door dendrietvormige uitgroei van $\mathrm{NaCl}$-kristallen. Deze kristalvorming staat onder invloed van geslachtshormonen (oestradiol en oestriol) en verscheidene hoogmoleculaire, oppervlaktespanning verlagende stoffen (Beck e.a. 1971).

Beck e.a. (1971) vonden dat het mogelijk was in vitro oplossingen te maken die, indien op een objectglas gebracht en gedroogd aan de lucht, tot dezelfde kristallisatie in staat 
hoofdstuk 2

waren als vruchtwater. De mooiste varens werden verkregen door $0,2 \mathrm{mg}$ chondroitinesulfaat $\mathrm{A}$ in $0,2 \mathrm{ml}$ van een $0,93 \% \mathrm{NaCl}$ oplossing te mengen en daarna op een objectglas gebracht te laten uitkristalliseren.

Figuur 2: Een voorbeeld van een varentest met vruchiwater.

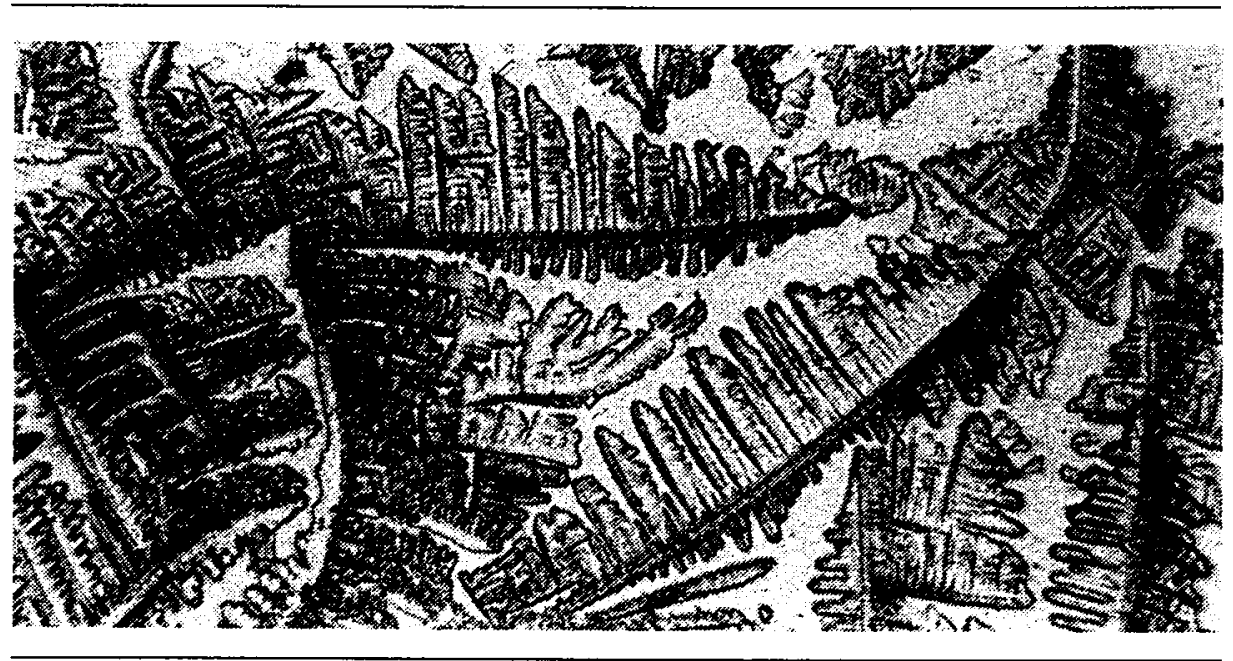

De varentest wordt gebruikt als een visueel en subjectief te herkennen fenomeen. Het is een uiterst snelle, goedkope en eenvoudig te beoordelen methode.

Vele onderzoekers hebben geprobeerd om de varentest te kwantificeren (Zondek 1959, Roland 1971, Moghossi e.a. 1972, Kesserue 1972). Niemand is in dat kwantificeren echt geslaagd (Kroeks 1976). Voor het aantonen van vruchtwater is dat overigens niet van belang en is kwalitatief onderzoek voldoende: er worden varens gezien of niet. $\mathrm{Bij}$ een positieve varentest bestaat de verdenking op tenminste bijmenging van vruchtwater. Wel moet bedacht worden dat vele andere lichaamsvloeistoffen ook in staat zijn tot het vormen van varens, zoals bloed, cervixslijm, semen en urine.

- pH-Bepaling

De pH-bepaling is de oudste (Gold 1927), meest beschreven en meest gebruikte techniek om vruchtwater aan te tonen. De $\mathrm{pH}$ in de vagina varieert tijdens de zwangerschap van circa 3 tot 5 . De $\mathrm{pH}$ van vruchtwater is circa 7 tot 8 , neutraal tot licht basisch.

Er zijn vele methoden om de $\mathrm{pH}$ te bepalen, bijvoorbeeld met behulp van broomthymolblauw (Temesvary 1933), lakmoes-indicatorpapier (Baptisti 1938) en de 
nitrazinetest (Abe 1940). Ook later is onderzoek met deze techniek verricht (Sklovsky en MacLennan 1976 en Mills en Garrioch 1977). De techniek is simpel, goedkoop en snel. Een belangrijk nadeel is dat de $\mathrm{pH}$ van urine alkalisch kan zijn, fluor vaginalis kan bij infecties alkalisch in plaats van zuur zijn. Ook bloedbijmenging en semen kunnen tot een verkeerde diagnose leiden, evenals desinfectantia en glijmiddelen.

- Methode van Iannetta

Een andere fysische methode om vruchtwater aan te tonen is die waarbij materiaal verkregen uit de endocervix wordt aangebracht op een objectglas en gedurende een minuut wordt verhit in een alcoholbrander (Iannetta 1984). Wit worden duidt op vruchtwater, een bruine verkleuring duidt op cervixslijm. Een verklaring voor dit fenomeen heeft de bovengenoemde onderzoeker niet noch is deze waarneming door anderen bevestigd.

\section{B. Cytologische methoden}

\section{- Lanugoharen}

De oudste "cytologische" methode die in verband staat met het aantonen van gebroken vliezen is vinden van lanugoharen (Phillip en Williams 1929). Het voordeel van deze methode is dat vaginaal afgenomen vocht niet behoeft gekleurd te worden alvorens het onder de microscoop te bekijken. Het grote nadeel is het geringe aantal lanugoharen dat men, ook na lang zoeken, kan aantreffen (Avarette e.a. 1963).

\section{- Vetcellen}

Het aantonen van foetale vetcellen kan op verschillende manieren. Eén van de methoden maakt gebruik van de Papanicolaou-kleuring. Dit is poliklinisch een niet makkelijk uit te voeren kleuring en de interpretatie is evenmin eenvoudig (Hopman e.a. 1957). De Vernitest is een test waarbij de vernix caseosa wordt gekleurd met pinacyanole-chloride. Deze kleuring is snel en eenvoudig uit te voeren (Avarette e.a. 1963). Het nadeel is het minimale kleurverschil tussen vaginale en foetale cellen. Vernix caseosa kan ook worden aangetoond met een Sudan-kleuring of de Nile-blue-sulfaattest (Kittrich 1963, Avarette e.a. 1963, Brosens en Gordon 1965). De Nile-blue-sulfaattest heeft de voorkeur door de eenvoud waarmee deze test is uit te voeren. Nile-blue is een oplossing die eosinophiel vet zoals vernix caseosa oranje/geel kleurt en vaginale cellen blauw/paars. Op een objectglas met enig vaginaal vocht wordt een druppel Nile-blue-sulfaat $0,1 \%$ gebracht en onder een microscoop bij een vergroting van $100 \mathrm{x}$ bekeken. De preparaten zijn eenvoudig te beoordelen (figuur 3). 


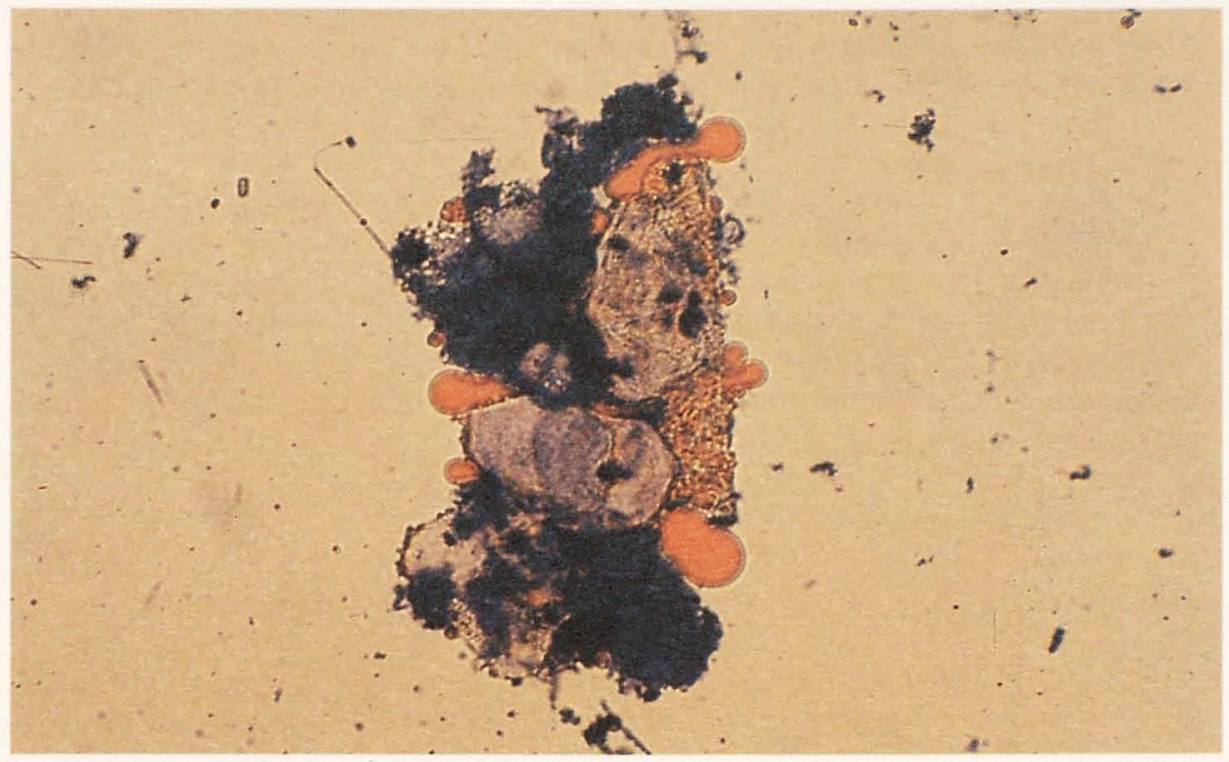

Het grote nadeel van al deze methoden is dat vernix caseosa pas voldoende in het vruchtwater voorkomt na de $34^{\mathrm{e}}$ week. De foetus is dan in staat om te transpireren. Transpiratievocht heeft een emulgerende werking op vernix caseosa. Hierdoor kan deze loslaten en wordt vernix caseosa gesuspendeerd in vruchtwater: vanaf de $34^{\mathrm{e}}$ week ontstaat langzaam de melkachtige verkleuring van vruchtwater (Voets 1975). De kans op fout-negatieve uitslagen voor de $34^{\mathrm{e}}$ week is erg groot.

- Foetale cellen

Reeds lang wordt gezocht naar een methode om specifiek foetale cellen aan te tonen. Een mogelijkheid zou de kleuring met methyleenblauw zijn: slechts gerijpte foetale huidcellen zouden met deze oplossing niet worden gekleurd (Langreder 1958).

Vele andere kleuringen zijn gebruikt, zoals een Masson-trichroom-kleuring (Bourgeois 1942) en acridine-oranje (Kushner e.a. 1964). Cellen van de navelstreng en van foetale organen zijn met deze twee laatste kleurmethoden terug te vinden. Aldus kan met deze methode de diagnose gebroken vliezen worden gesteld (Huisjes 1968). Het grote nadeel van deze methoden is, dat de preparaten alleen zeer ervaren cytologen kunnen beoordelen. 


\section{Chemische methoden}

\section{- Diamine-oxidase}

De eerste chemische test die werd beschreven in de literatuur, om de diagnose gebroken vliezen aan te tonen, maakte gebruik van de hoge concentratie van het enzym diamine-oxidase in vruchtwater (Elmfors e.a. 1974). Diamine-oxidase werd in 1929 ontdekt door Best. Later kreeg dit enzym ook de naam histaminase mee. Ondanks het feit dat deze namen vaak als synoniemen werden gebruikt, zijn het mogelijk verschillende enzymen. Diamine-oxidase voorkomt dat diamines van het kind in de circulatie van de moeder terecht komen.

De concentratie in het vruchtwater ten opzichte van het bloed van de moeder zou tweemaal zo hoog zijn. Het nadeel van deze methode is dat het noodzakelijk is $\mathrm{C}_{14}$-isotopen te gebruiken.

\section{- $\alpha$-Foetoproteïne-concentratie}

De $\alpha$-foetoproteïne-concentratie (AFP) is een parameter die in het vruchtwater uitvoerig is onderzocht. Normaalwaarden in de ongecompliceerde en de gecompliceerde zwangerschap zijn bekend (Seppälä en Ruoslahti 1972, Allan e.a. 1973, Barford ẹ.a. 1985). De bepaling van AFP wordt al geruime tijd gebruikt voor het aantonen van neurale buisdefecten (Allan e.a. 1973, Roberts e.a. 1979). De AFP-concentratie wordt pas recent gebruikt om de diagnose gebroken vliezen te bevestigen (Rochelson e.a. 1983, 1987, Huber e.a. 1983).

In de zeventiger jaren was de AFP-bepaling alleen mogelijk met behulp van Radio-Immuno-Assay-technieken (R.I.A.).

In de tachtiger jaren zijn monoclonale antilichamen beschikbaar gekomen. Hiermee is een test, met een gegeven detectieniveau, eenvoudig uit te voeren. Een belangrijk nadeel is evenwel dat bloedbijmenging na de $34^{e}$ tot $36^{e}$ week van de zwangerschap fout-positieve uitslagen kan geven. Weliswaar is in het begin van de zwangerschap de AFP-concentratie in het vruchtwater vele malen hoger dan die in het matemale bloed (Barford e.a. 1985), maar tegen het einde van de zwangerschap daalt de concentratie in het vruchtwater zodanig dat fout-positieve uitslagen kunnen optreden.

\section{- Glucose en fructose}

Ook glucose- en fructosebepalingen werden gebruikt om de diagnose P.R.O.M. te stellen (Gorodeski e.a. 1979).

Glucose- en fructosebepalingen in cervixslijm werden al eerder beschreven (Weed en Carrera 1970). Het bleek dat de concentratie in cervixslijm ongeveer 7 maal zo hoog is als die in het vruchtwater. Daarmee lijkt de glucose- en fructosebepaling niet geschikt om vruchtwater in positieve zin te onderscheiden van cervixslijm. 
hoofdstuk 2

- Hormoonbepalingen

In de tachtiger jaren kwamen een aantal hormoonbepalingen ter beschikking die betrouwbare resultaten gaven, ook als er maar kleine hoeveelheden vocht beschikbaar waren. Genoemd kunnen worden: humaan Placental Lactogen (hPL) en prolactine (Koninckx e.a. 1981, Huber e.a. 1983). De hierbij gebruikte R.I.A.-bepalingen vergen veel tijd, zijn duur en niet in alle ziekenhuislaboratoria uitvoerbaar. Het laatste bezwaar is vervallen met de komst van fluorescentie-technieken, enzymatische bepalingen en monoclonale antilichaam-bepalingen.

De resultaten van de hPL-bepalingen zijn minder hoopvol daar de spreiding van de concentraties in met name vruchtwater en bloed groot is. Bovendien is het concentratieverschil tussen vruchtwater en maternaal bloed gering. De resultaten van de prolactine-bepalingen zijn daarentegen hoopvol en dit diagnosticum komt in dit onderzoek dan ook nog uitvoerig aan de orde.

\subsubsection{Invasieve methoden}

\section{- Amniocentese}

Het is mogelijk om transabdominaal een weinig kleurstof in de amnionholte te injecteren en aldus het gebroken zijn van de vliezen aan te tonen. De hiervoor benodigde amniocentese werd door een aantal onderzoekers verricht (Atlay en Sutherst 1970, Smith 1976) waarbij kleurstoffen werden gebruikt als: methyleenblauw, Evans-blue en natriumfluoresceine. Voor de neonatale problemen, zoals allergische reacties en haemolytische anaemieën, werd eerst later gewaarschuwd (Cowett e.a. 1976, Kirsch en Cohen 1980).

Een ander nadeel van de invasieve techniek is het niet te verwaarlozen complicatiepercentage van de amniocentese op zich (paragraaf 1.1).

\section{- Het onderzoek in speculo}

Ook het onderzoek in speculo, om het aflopen van vruchtwater te zien, kan beschouwd worden als een invasieve techniek om gebroken vliezen aan te tonen. Complicaties in de vorm van infecties worden beschreven (Schutte 1981).

\subsubsection{Overige methoden}

Enkele methoden zijn als zodanig wel in de literatuur beschreven, maar niet als diagnosticum bij mogelijk gebroken vliezen. 
Omdat deze methoden toch van betekenis zouden kunnen zijn, bij deze diagnostiek, volgt hier een kort overzicht. Ook hier is weer sprake van een verdeling in drie groepen (tabel 6).

Tabel 6: Overige, "theoretische" methoden.

Subjectieve methoden

- het ruiken van vruchtwater

- de echoscopie

Objectieve methoden

- het aantonen van lecithine en sfingomyeline

- het aantonen van phosphatidylglycerol

- het aantonen van vruchtwaterspecifiek alkalisch fosfatase

Invasieve methoden

- het vaginale toucher

- de amnioscopie

\section{A. Subjectieve methoden}

- Het ruiken van vruchtwater

Vruchtwater heeft voor sommigen een karakteristieke geur. Als veel vruchtwater afloopt zal de anamnese en het ruiken van vruchtwater, door personen die dit reukvermogen bezitten, direct de juiste diagnose kunnen opleveren. Dit zou steeds als diagnosticum kunnen worden gebruikt ware het niet dat kleine hoeveelheden aflopend vruchtwater -en daar gaat het bij dubieus gebroken vliezen om- zeer moeilijk aan te tonen zijn op deze wijze.

\section{- Echoscopie}

Met behulp van echoscopie kan de inhoud van de uterus in beeld gebracht worden. De hoeveelheid vruchtwater is te schatten, maar uit onderzoek blijkt dat ongeveer $8 \%$ van de zwangeren vruchtwaterpockets hebben met een doorsnede niet groter dan 2 centimeter (grens voor oligohydramnion). Deze patiënten hoeven uiteraard helemaal 
hoofdstuk 2

geen gebroken vliezen te hebben (Rabe e.a. 1986). Anderzijds zal het duidelijk zijn dat een hoge vliesscheur, waarbij slechts kleine hoeveelheden vruchtwater afgelopen zijn, gemakkelijk kan worden gemist.

\section{B. Objectieve methoden}

- Het aantonen van lecithine en sfingomyeline

Lecithine en sfingomyeline zijn twee oppervlakte-spanning verlagende stoffen die zowel in het vruchtwater als in het bloed van de moeder voorkomen. De bepaling van lecitine en sfingomyeline vindt plaats met behulp van dunnelaag chromatografie.

Niet alleen bloedbijmenging kan tot een verkeerde conclusie leiden, ook kunnen door verontreiniging van vaginaal afgelopen vocht technische problemen optreden. Op de plaats van het chromatogram waar lecithine of sfingomyeline wordt gezien ontstaat dan een opeenhoping van vlekken waardoor het aantonen van beide stoffen moeilijk en de schatting van de hoeveelheid vrijwel is uitgesloten. Indien deze methode mogelijkheden zou bieden, zou een bijkomend voordeel zijn dat informatie beschikbaar komt over de longrijpheid van de foetus.

\section{- Het aantonen van phosphatidylglycerol}

De bepaling van phosphatidylglycerol met de tegenwoordig beschikbare monoclonale antilichamen zou een goede test kunnen zijn. Immers met deze techniek wordt geen hinder ondervonden van verontreiniging. Helaas is phosphatidylglycerol pas aantoonbaar in het vruchtwater als de longen rijp zijn waardoor deze methode niet in de gehele zwangerschap kan worden gebruikt.

- Het aantonen van vruchtwater-specifiek alkalisch fosfatase

Het aantonen van vruchtwater-specifiek alkalisch fosfatase leek hoopgevend. Door verschillende onderzoekers werd geopperd dat het alkalisch fosfatase van het vruchtwater een andere structuur had dan de alkalisch fosfatasen die in andere lichaamsvloeistoffen werden aangetoond (Kellen e.a. 1970, Hahnemann en Sörensen 1974 en Voets 1975). Maar na deze eerste meldingen zijn geen verdere mededelingen gedaan omtrent vruchtwater-specifiek alkalisch fosfatase.

\section{Invasieve methoden}

- Het vaginale toucher

Met behulp van een vaginaal toucher is het vaak mogelijk om de diagnose staande dan wel gebroken vliezen te stellen. Het grote nadeel is het verhoogde risico op een intrauteriene infectie (Schutte 1981). Bovendien is het moeilijk om de aanwezigheid 
van een staande vochtblaas te constateren als de vliezen strak om het hoofd van de foetus zitten. Omgekeerd zal een hoge vliesscheur niet te diagnostiseren zijn.

Het vaginale toucher is dan ook een ongewenst en ongeschikt hulpmiddel bij de diagnostiek van gebroken vliezen.

\section{- Amnioscopie}

Met behulp van een amnioscoop zijn de vliezen zichtbaar te maken. Ook voor deze methodiek geldt het risico op een intrauteriene infectie.

\subsection{Nieuwe methoden}

Recent werd in de literatuur beschreven dat het met behulp van monoclonale antilichamen mogelijk is om vruchtwater-specifieke stoffen aan te tonen, zoals fibronectine en Insuline-like Growth Factor Binding Protein-1 (IGFBP-1). Deze bepalingen zouden voor het stellen van de diagnose gebroken vliezen kunnen worden gebruikt (Casal 1990 en Rutanen 1991). De betrouwbaarheid ervan is evenwel niet bekend bij patiënten met dubieus gebroken vliezen.

\section{Discussie}

Daar de etiologie van het voortijdig breken van de vliezen waarschijnlijk multifactorieel is kan een risicogroep niet worden aangegeven.

Het voortijdig breken van de vliezen komt volgens de literatuur voor bij één op de tien zwangerschappen. Daarmee is het van belang om goede maar ook eenvoudige diagnostische technieken om gebroken vliezen aan te tonen ter beschikking te hebben.

Het breken van de vliezen heeft, zo is af te leiden uit de literatuur, grote consequenties voor zowel moeder, foetus als neonatus. Ook hierdoor zijn goede diagnostische mogelijkheden om gebroken vliezen aan te tonen van groot belang.

In de literatuur worden vele tests beschreven waarmee vruchtwater zou kunnen worden. aangetoond. Op theoretische gronden kunnen nog een aantal diagnostische mogelijkheden worden toegevoegd aan dit arsenaal.

Dit grote aantal doet vermoeden dat de ideale methode nog niet is gevonden. Dit onderzoek poogt dit ideaal meer naderbij te brengen. 



\section{Hoofdstuk 3}

\section{De enquête}

\subsection{Inleiding}

Zoals eerder vermeld (hoofdstuk 1), is het stellen van de diagnose gebroken vliezen niet moeilijk indien een patiënte veel vocht verliest uit de cervix uteri. De incidentie van voortijdig gebroken vliezen is dan ook uit de literatuur bekend. Geen literatuur is echter beschikbaar waarin de incidentie van het twijfelen aan gebroken vliezen wordt beschreven. Bovendien levert het stellen van de diagnose gebroken vliezen als een patiënte weinig vocht verliest doorgaans meer problemen op. Ter inventarisatie van de grootte van dit probleem werd een enquête verricht.

Enige basisgegevens zoals pariteit, leeftijd en amenorroeduur van deze enquêtegroep, waarbij dus werd getwijfeld aan het gebroken zijn van de vliezen, werden bewerkt. Deze gegevens zijn van belang om te kunnen beoordelen in hoeverre deze enquêtegroep verschilt van zowel de groepen patiënten van de S.I.G. (kortdurend en langdurig gebroken vliezen), als de patiëntengroep die werd gebruikt voor de bepaling van de referentiewaarden (zeker staande of gebroken vliezen) als de groep met dubieus gebroken vliezen én van de totale populatie in de 3 deelnemende klinieken.

Het klachtenpatroon van de patiënten werd bestudeerd evenals het verrichte onderzoek en de bijbehorende bevindingen van de hulpverleners. Mogelijk zouden deze gegevens een bijdrage kunnen leveren bij het stellen van de diagnose gebroken vliezen.

\subsection{Opzet van het onderzoek}

Drie verloskundige afdelingen van ziekenhuizen in de regio Zuid-Limburg namen deel aan dit onderzoek:

- het academisch ziekenhuis Maastricht

- het De Wever-Ziekenhuis te Heerlen

- de Sint Elisabeth Kliniek te Heerlen. 
hoofdstuk 3

Van 01-01-1985 tot 01-01-1986 werden door de deelnemende klinieken bij twijfel aan het gebroken zijn van de vliezen, registratieformulieren ingevuld (bijlage 2). Het twijfelen werd als volgt gedefinieerd: na anamnese en eenvoudig onderzoek (onderzoek in speculo, varentest, pH-test) is het niet duidelijk of de vliezen staan dan wel gebroken zijn.

\subsection{Resultaten van de enquête}

\subsubsection{Incidentie van twijfel aan het gebroken zijn van de vliezen}

In de periode van de enquête werden 166 ingevulde formulieren ontvangen: $5,7 \%$ van het aantal patiënten dat in de drie genoemde klinieken beviel (totaal 2903 baringen). De incidentie in de verschillende klinieken varieerde van $4,6 \%$ tot $7,1 \%$.

\subsubsection{Pariteit, leeftijd en amenorroeduur in de enquêtegroep}

Een aantal kenmerken van patiënten in de enquêtegroep werd nader bezien, met name pariteit en leeftijd (het gebruikte registratieformulier en de coderingslijst zijn bijgevoegd als bijlage 3 en 4). In de enquêtegroep was 50\% primigravida, een vergelijkbaar percentage (53\%) werd gevonden in de totale populatie van de drie klinieken. De gemiddelde leeftijd van de patiënten die werden ingebracht in de enquêtegroep was 27 jaar. Dezelfde gemiddelde leeftijd werd gevonden in de totale populatie van patiënten die in de deelnemende klinieken bevielen.

De verdeling van de amenorroeduur in de enquêtegroep is weergegeven in tabel 7.

Tabel 7: De verdeling van het aantal patiënten in de enquêtegroep naar amenorroe in aantallen en percentages.

\begin{tabular}{rrr} 
& $\begin{array}{r}\text { Aantal } \\
\mathrm{n}=166\end{array}$ & $\begin{array}{r}\text { Percentage } \\
(\%)\end{array}$ \\
\cline { 2 - 3 } $\begin{array}{r}\text { amenorroe } \\
\text { (weken) }\end{array}$ & & \\
216 en $<20$ & & 1,8 \\
220 en $<24$ & 3 & 5.4 \\
$\geq 24$ en $<28$ & 9 & 8,4 \\
$\geq 28$ en $<32$ & 14 & 4.2 \\
232 en $<36$ & 7 & 13,9 \\
$\geq 36$ en $\leq 42$ & 23 & 66,3
\end{tabular}


Uit tabel 7 kan worden geconcludeerd dat het twijfelen aan het gebroken zijn van de vliezen weliswaar voorkomt in de gehele onderzochte zwangerschapsperiode, maar vooral in de à terme periode. Toch valt ook op dat relatief vaak (in $34 \%$ van de patiënten van de enquêtegroep) tijdens de immature of premature periode werd getwijfeld aan het gebroken zijn van de vliezen.

Vergelijking van de verdeling van de amenorroeduur van de enquêtegroep met de totale populatie was niet zinvol daar de amenorroeduur bij het twijfelen aan het gebroken zijn van de vliezen meestal niet dezelfde was als de amenorroeduur bij de partus.

\subsubsection{Klachten van de patiënten in de enquêtegroep}

Zoals uit bijlage 2 blijkt, was het voor de onderzoeker mogelijk om de klachten waarmee patiënten zich presenteerden te omschrijven. De genoteerde klachten zijn te verdelen in 7 categorieën (tabel 8).

Tabel 8: Overzicht van de klacht(en) waarmee de patiënten zich presenteerden.

Aantal

\begin{tabular}{rr} 
& Aantal \\
\cline { 2 - 2 } klacht & \\
vochtverlies & \\
blocdverlics & 157 \\
weeénactiviteit & 11 \\
mictieklachten met & 12 \\
vochtverlies & \\
rugklachten & 6 \\
fluorklachten & 3 \\
slijmverlies & 3 \\
& 6
\end{tabular}

Zoals uit tabel 8 blijkt zijn er patiënten die zich met meer dan één klacht presenteerden. Van de 166 patiënten hadden 132 patiënten $(80 \%)$ slechts één klacht: vochtverlies. De duur van de klacht(en) is vermeld in tabel 9. 
Tabel 9: Overzicht van het aantal dagen dat de klacht bestond alvorens de patiënte zich tor haar hulpverlener wendde.

\begin{tabular}{rr}
\hline & Aantal \\
$n=166$ & \\
duur klacht & \\
(dagen) & \\
& \\
$0-1$ & 131 \\
$1-2$ & 13 \\
$2-3$ & 3 \\
$3-4$ & 2 \\
$4-5$ & 4 \\
$5-6$ & 0 \\
$6-7$ & 5 \\
27 & 8 \\
\hline
\end{tabular}

De spreiding in tijd, tussen het optreden van de klacht tot het zoeken van hulp, was groot: er waren patiënten die zich binnen een uur na het optreden van de klacht meldden op de polikliniek, anderen wachtten meer dan een week.

\subsubsection{Onderzoek dat werd verricht in de enquêtegroep}

Het onderzoek dat door de verschillende hulpverleners werd uitgevoerd was niet identiek. Door de meesten werd een onderzoek in speculo uitgevoerd (144 maal), bij 22 patiënten werd daar vanaf gezien (13\%). De bevindingen van het onderzoek in speculo zijn samengevat in tabel 10 .

Tabel 10: Bevindingen bij het onderzoek in speculo bij patiënten van de enquêtegroep.

$\begin{array}{rr}\text { bevinding } & \begin{array}{r}\text { Aantal } \\ n=144\end{array} \\ \text { vocht al dan niet met vlokjes } & \\ \text { bloed uit het ostium } & 45 \\ \text { ruime fluor } & 10 \\ \text { normale bevindingen (geen vocht) } & 36 \\ \text { slijmprop in het ostium } & 30 \\ \text { zichtbaar staande vliezen } & 20 \\ & 3\end{array}$

In totaal werd bij 104 patiënten vocht verkregen (63\%). Bij $37 \%$ van de patiënten werd geen vocht verkregen. $\mathrm{Bij}$ de patiënten waarbij geen vocht kon worden opgezogen is bij 20 patiënten toch een varentest gemaakt. Er werd dan kennelijk een varentest gemaakt van vocht uit de vagina of van cervixslijm. 
Bij patiënten waarbij geen onderzoek in speculo werd uitgevoerd is bij 10 patiënten een minder "invasief" onderzoek verricht: een echoscopie (om de diagnose gebroken vliezen te stellen). Bij 4 van deze 10 patiënten bleef het bij dit onderzoek. Bij 6 patiënten werd hierna een vaginaal toucher uitgevoerd.

In de totale "enquêtegroep" werd bij 35 van de 166 patiënten (21\%), dus bij 25 patiënten op een veel later tijdstip dan het moment van de klacht, een echoscopie verricht. Zoals reeds vermeld, speelde bij slechts 4 patiënten de echo een doorslaggevende rol bij het verder te voeren beleid. Hieruit valt op te maken dat de echoscopie bij de behandelaars een ondergeschikte rol speelt als diagnostische mogelijkheid bij deze "aandoening".

Uit de enquête bleek dat de meeste behandelaars de varentest prefereerden boven andere tests om vruchtwater aan te tonen. Bij 124 patiënten werd een varentest beoordeeld. $\mathrm{Bij} 25 \%$ van de patiënten werd hiervan afgezien. Van deze varentests was het resultaat 84 maal negatief en 38 maal positief. Van twee patiënten was het resultaat niet bekend. Van de 38 patiënten waarbij de varentest positief was werden 36 patiënten opgenomen, één patiënte was al opgenomen en één patiënte werd niet opgenomen. Indien de varentest negatief was ( 84 patiënten) werden 28 patiënten toch opgenomen, 7 patiënten waren reeds opgenomen en 49 patiënten mochten na controle de kliniek verlaten.

De $\mathrm{pH}$ van het aflopende vocht werd bij 63 patiënten (38\%) bepaald. Van de patiënten waarbij een $\mathrm{pH}$ werd bepaald was het resultaat 26 maal $\geq 7$, wijzend op het gebroken zijn van de vliezen. Deze patiënten werden, op één uitzondering na, opgenomen of waren reeds opgenomen. Indien de $\mathrm{pH}<7$ was, werden 16 patiënten opgenomen, 1 patiënte was al opgenomen (totaal $46 \%$ ) en 20 patiënten gingen weer naar huis.

De geënquêteerden noteerden op het formulier (bijlage 2) nog een aantal aanvullende onderzoeken (tabel 11).

Tabel 1l: Aanvullend onderzoek dat werd verricht in de enquêtegroep.

aanvullend onderzoek

bepaling L/S-ratio

cervixkweek

vaginale toucher

amnioscopie

Nile-blue-sulfaat-test 
hoofdstuk 3

observatie-percentage van 59\% van de patiënten waarbij oorspronkelijk aan het gebroken zijn van de vliezen getwijfeld werd.

Bij evaluatie van de patiëntengegevens bleek met behulp van de gouden standaard (hoofdstuk 1) dat 59 patiënten in de enquêtegroep in werkelijkheid gebroken vliezen hadden, 80 patiënten staande vliezen en bij 27 patiënten bleef de diagnose onduidelijk. Uit bovenstaande getallen blijkt dat teveel patiënten klinisch worden geobserveerd.

\section{Conclusies}

1. Het twijfelen aan het gebroken zijn van de vliezen is een relatief frequent voorkomend probleem: per 17 gecontroleerde zwangerschappen werd gemiddeld eenmaal getwijfeld aan het staan van de vliezen. De eerste vraagstelling van dit onderzoek (hoofdstuk 1) is hiermede beantwoord.

2. Patiënten zoeken regelmatig relatief laat hulp: 35 van de 166 patiënten kwamen later dan 24 uur na het begin van de klacht (vochtverlies).

3. Indien een patiënte hulp zocht en aan het gebroken zijn van de vliezen werd getwijfeld, dan werd vaak een onderzoek in speculo verricht: in $87 \%$.

4. De varentest was de meest (124 van de 166) gebruikte diagnostische methode bij twijfel omtrent het gebroken zijn van de vliezen.

5. Het positief zijn van de varentest was kennelijk een alarmsignaal voor de onderzoeker: $97,5 \%$ van de patiënten werd verder klinisch geobserveerd.

6. De pH-bepaling werd veel minder frequent uitgevoerd: bij 63 van de 166 werd een $\mathrm{pH}$ bepaald.

7. Als de $\mathrm{pH} \geq 7$ was werd dit klaarblijkelijk als een "bewijs" voor het gebroken zijn van de vliezen beschouwd: $96 \%$ van de patiënten werd verder klinisch geobserveerd.

8. De echoscopie werd bij twijfel aan het gebroken zijn van de vliezen niet als belangrijk gezien.

9. Een vaginaal toucher werd niet zelden (20,5\%) uitgevoerd bij twijfel aan het gebroken zijn van de vliezen. 
enquête

Discussie

Bij ruim 5\% van alle zwangerschappen werd getwijfeld aan het gebroken zijn van de vliezen. Of dit percentage ook voor "niet-geënquêteerde zwangerschappen" in geheel Nederland geldt is de vraag. Er kan sprake zijn van een lichte onder- of overschatting. Immers:

De deelnemers kunnen, ondanks uitvoerige instructies, zijn beïnvloed door de definitie van "twijfel". Als definitie werd genomen: "het niet duidelijk zijn van de continuïteit van de vliezen na anamnese en eenvoudig onderzoek". Als voorbeelden van eenvoudig onderzoek werden genoemd: het onderzoek in speculo, de varentest, het bepalen van de $\mathrm{pH}$. Ten onrechte kunnen sommigen hebben gedacht dat eerst al deze onderzoeksmethoden moesten hebben plaats gevonden alvorens aan de diagnose gebroken vliezen mocht worden getwijfeld.

- De mate van respons bleef deels oncontroleerbaar: er kon aan het gebroken zijn van de vliezen getwijfeld worden zonder een enquêteformulier in te vullen. 



\section{Hoofdstuk 4}

\section{Nederlandse gegevens over langdurig gebroken vliezen}

\subsection{Inleiding}

Hoewel in de literatuur is aangetoond (hoofdstuk 2) dat aan het langdurig gebroken zijn van de vliezen nadelen zijn verbonden leek het zinvol dit te toetsen aan de Nederlandse situatie. Tevens konden de verkregen resultaten van de Nederlandse patiënten met langdurig, respectievelijk kortdurend gebroken vliezen, worden vergeleken met de resultaten van de enquêtegroep en de groep met dubieus gebroken vliezen van de steekproef in Zuid-Limburg.

De Nederlandse gegevens van patiënten met langdurig (langer dan 24 uur) gebroken vliezen werden vergeleken met gegevens van patiënten met kortdurend (korter of gelijk aan 24 uur) gebroken vliezen. Het doel van het vergelijken van deze twee groepen was het onderzoeken of ook in Nederland een verhoogde morbiditeit of mortaliteit bij moeder en/of kind voorkwamen als de vliezen langdurig waren gebroken. Op deze wijze kan het belang van diagnostiek, bij twijfel aan de diagnose staande of gebroken vliezen, worden bevestigd.

Gekozen is voor de vergelijking van de groep met korter of gelijk aan 24 uur gebroken vliezen en de groep met langer gebroken vliezen, omdat wordt aangenomen dat geen grote nadelen aan het kortdurend gebroken zijn van de vliezen zijn verbonden (paragraaf 2.4).

\subsection{Opzet van het onderzoek}

In Nederland zijn er twee instanties die zich bezighouden met het landelijk verzamelen en statistisch bewerken van verloskundige gegevens.

Deze instanties zijn:

- Centraal Bureau voor de Statistiek (C.B.S.)

- Stichting Informatiecentrum voor de Gezondheidszorg (S.I.G.).

Met beide instanties werd contact gezocht, alleen de S.I.G. bleek over gedetailleerde gegevens te beschikken van in ziekenhuizen geboren kinderen. In Nederland nemen een groot aantal ziekenhuizen deel aan de centrale registratie die deze stichting aanbiedt. De deelname hieraan is op vrijwillige basis. Totaal werden in 1985 in Nederland 178.136 kinderen geboren. 
hoofdstuk 4

De S.I.G. registreerde in 1985 in totaal 65.023 geboorten. Dit komt overeen met ruim $36 \%$ van het totaal aantal kinderen en $77 \%$ van de in ziekenhuizen geboren kinderen. Uit het gehele bestand werden de gegevens van die geboorten geselecteerd waarbij de vliezen langer dan 24 uur waren gebroken. Een aselecte steekproef werd genomen uit de groep met niet langdurig gebroken vliezen. Deze groep diende als aselecte controlegroep en werd ongeveer even groot genomen als de groep met langer dan 24 uur gebroken vliezen.

Vergeleken werden twee groepen:

Groep K: Uit het gehele bestand, uitgezonderd de registraties met langer dan 24 uur gebroken vliezen, nam het S.I.G. een aselecte steekproef. Deze groep bestond uit 4890 registraties.

Groep L: alle registraties die bij de S.I.G. zijn ontvangen in het jaar 1985 en waarbij de vliezen langer dan 24 uur waren gebroken. Deze groep bestond uit 4895 registraties.

Het S.I.G.-formulier (bijlage 5) bestaat uit 7 onderdelen:

1. Het identificatiegedeelte

2. Een gedeelte met anamnestische gegevens van de moeder

3. Gegevens van de huidige zwangerschap

4. Gegevens van de partus

5. Gegevens over het kind

6. Bijzonderheden over het kraambed

7. Eigen coderingen.

Het eerste gedeelte is niet gebruikt ter bescherming van de privacy.

De delen 2 tot en met 6 werden bewerkt voor dit onderzoek.

Een aantal gegevens die in het zevende deel kunnen worden ingevuld is voor dit onderzoek uitermate interessant. Te noemen zijn: het hebben van een abortus provocatus in de anamnese, congenitale uterusanomalie al dan niet geopereerd, exconisatie en/of portioamputatie, nicotinemisbruik in de graviditeit, weeënremming met opname, bloedverlies eerste helft, bloedverlies tweede helft, cerclage en het hebben van een geinfecteerde uterusinhoud voor de geboorte van het kind.

Dit zijn echter facultatief in te vullen gegevens, aan de volledigheid van dit soort gegevens moet om die reden worden getwijfeld. Dit blijkt ook uit het feit dat maar zelden van de geboden mogelijkheid werd gebruik gemaakt. 


\subsubsection{Insluitcriteria voor dit deel van het onderzoek}

Bij de bewerking van de gegevens bleek dat deze niet altijd voldeden aan de voorwaarden die er vooraf aan werden gesteld. Daarom werden insluitcriteria gedefinieerd.

\section{Insluitcriterium 1: $\geq 16$ weken amenorroe.}

Indien geen amenorroeduur was ingevuld, of de amenorroe niet bekend was, werd de registratie uit het bestand verwijderd.

Aantallen registraties die niet voldeden aan insluitcriterium 1:

$\begin{array}{rr}\text { groep K } & \text { groep L } \\ \text { (niet langdurig } & \text { (wel langdurig } \\ \text { gebroken vliezen) } & \text { gebroken vliezen) } \\ 52 \text { registraties } & 30 \text { registraties }\end{array}$

Insluitcriterium 2: $\leq 42$ weken amenorroe.

Aantallen registraties die niet voldeden aan insluitcriterium 2:
groep $\mathrm{K}$
272 registraties
groep L
201 registraties

\section{Insluitcriterium 3: Zekerheid van de amenorroe.}

Indien de à terme datum als "onzeker" was aangegeven werd de registratie uit het bestand verwijderd.

Aantallen registraties die niet voldeden aan insluitcriterium 3:
groep $\mathrm{K}$
674 registraties
groep L
720 registraties

Insluitcriterium 4: Alleen eenlingen werden in het onderzoek opgenomen.

Aantallen registraties die niet voldeden aan insluitcriterium 4:

groep $\mathrm{K}$

227 registraties groep L

181 registraties 
hoofdstuk 4

Alleen eenlinggraviditeiten werden geaccepteerd daar de meerlinggegevens vaak niet compleet waren (tabel 12).

Tabel 12: Overzicht van de verdeling van het aantal meerlingen in de groep met $\leq 24$ uur gebroken vliezen en de groep met $>24$ uur gebroken vliezen.

\begin{tabular}{rrrr}
\hline & groep K & groep L \\
eerste kind tweeling & 122 & eerste kind tweeling & 116 \\
tweede kind tweeling & 104 & tweede kind tweeling & 63 \\
derde kind drieling & 1 & derde kind drieling & 1 \\
vierde kind vierling & 0 & & \\
vijfde kind vijfling & 0 & & \\
zesde kind zesling & 1 & & \\
\hline
\end{tabular}

Het ontbreken van 53 tweede kinderen van een meerling, in groep L, kan misschien worden verklaard doordat is aangenomen dat indien de vliezen van een kind bij een meerling gebroken zijn de vliezen van het andere kind korter dan 24 uur gebroken kunnen zijn.

Moeilijker is de verklaring voor het ontbreken van 18 tweede kinderen van een meerling en het ontbreken van het vierde en het vijfde kind van een zesling in de groep met kortdurend gebroken vliezen. Deze 18 kinderen en het vierde en vijfde kind van een zesling zouden dan geboren zijn nadat de vliezen langdurig gebroken waren.

De aselecte steekproef (groep K) bestond aanvankelijk uit 4890 registraties en de groep met langdurig gebroken vliezen (groep L) uit 4895 registraties.

$\mathrm{Na}$ toepassing van de insluitcriteria zijn de aantallen:

groep $\mathrm{K}$

3799 registraties

\subsection{Uitkomsten van het onderzoek}

\subsubsection{Incidentie van voortijdig gebroken vliezen}

Uit de S.I.G.-gegevens is het mogelijk een indruk te verkrijgen omtrent het voorkomen van voortijdig gebroken vliezen. Vermeld wordt het begin van de baring (spontaan of inleiding, begin met weeën of een spontane vliesscheur; hier konden ook combinaties, maximaal 2, worden aangegeven) en het tijdstip van het geboren worden van het kind. Dit incidentiecijfer is van belang voor dit onderzoek. 
Tabel 13: Hel aantal registraties in de groep met korter of gelijk aan 24 uur gebroken vliezen (groep K) en in de groep met langer dan 24 uur gebroken vliezen (groep L) naar het begin van de baring.

\begin{tabular}{rrrrr}
\hline & $\begin{array}{r}\text { groep K } \\
\mathrm{n}=3799\end{array}$ & $\%$ & $\begin{array}{r}\text { groep L } \\
\mathrm{n}=3870\end{array}$ & $\%$ \\
\cline { 2 - 4 } & & & & \\
begin van de baring & & & 967 & 25.0 \\
Spontane weeèn & 2467 & 64.9 & 2472 & 63.9 \\
spontane vliesscheur & 589 & 15.5 & 110 & 2,8 \\
inleiding amniotomie & 262 & 6.9 & 258 & 6.7 \\
inleiding chemisch & 290 & 7.6 & 37 & 1,0 \\
prim. sectio caesarca & 179 & 4,7 & 26 & 0.7 \\
onbekend & 12 & 0.3 & & \\
\hline
\end{tabular}

Uit tabel 13 is de incidentie van het voortijdig breken van de vliezen in de door de S.I.G. geregistreerde patiëntengegevens als volgt te berekenen.

We nemen aan dat groep $\mathrm{K}$ een representatieve steekproef is van de patiëntengegevens die door de S.I.G. zijn geregistreerd. In het S.I.G.-bestand, exclusief de patiënten met langdurig gebroken vliezen, zullen dan bij 9320 patiënten de vliezen voortijdig gebroken zijn. In de groep met langdurig gebroken vliezen is de incidentie $63,9 \%$ of 3128 patiënten. In het gehele S.I.G.-bestand zullen dan bij 12.448 patiënten de vliezen voortijdig zijn gebroken. De incidentie van het voortijdig breken van de vliezen is in de S.I.G.-gegevens: $19,1 \%$. Dit percentage mag hoog worden genoemd in vergelijking met de literatuurgegevens (paragraaf 2.3 ).

De vergelijking van de samenstelling van de groep met kortdurend gebroken vliezen en die met langdurig gebroken vliezen leert dat de verschillen tussen de groepen significant zijn $(\mathrm{p}<0,0001)$. Zoals te is verwachten blijkt dat in de groep met langer dan 24 uur gebroken vliezen in een hoog percentage $(63,9 \%)$ dit breken der vliezen optreedt voor de weeënactiviteit begint. Aan te nemen is dat deze patiënten relatief laat hulp zullen zoeken, zeker wanneer het weinig vochtverlies betreft. In de groep met kortdurend gebroken vliezen is de frequentie van het voorkomen van een vliesscheur voordat weeënactiviteit optreedt uiteraard lager $(15,5 \%)$.

In de groep met minder of gelijk aan 24 uur gebroken vliezen werd $6,9 \%$ van de baringen door een amniotomie ingeleid. In de groep met langer dan 24 uur gebroken vliezen is dat $2,8 \%$.

Dit verschil is significant met behulp van de chi-kwadraat-toets $(p<0,0001)$ en zeer wel als complicatie te beschouwen van iatrogene interventies. 
hoofdstuk 4

In de groep met meer dan 24 uur gebroken vliezen werd significant minder $(p<0,0001)$ vaak een primaire sectio caesarea verricht. Mogelijk is de verklaring simpel en wel gelegen in het feit dat velen een primaire sectio caesarea en het spontaan breken van de vliezen als een contradictio in terminis beschouwen.

\subsubsection{Duur van het gebroken zijn van de vliezen}

Er is een verband te leggen tussen de duur van de latente periode (de tijd tussen het breken van de vliezen en het in partu komen) en de amenorroeduur bij het breken van de vliezen. Ook wordt een verband gevonden tussen de duur van de latente periode en het optreden van mortaliteit en morbiditeit (paragraaf 2.4).

Helaas is uit de S.I.G.-gegevens die voorhanden zijn niet te achterhalen hoe lang de latente fase duurt: het moment waarop de vliezen braken is weliswaar bekend, maar niet het moment waarop de weeën begonnen.

Als afspiegeling van de latente fase is de duur van het gebroken zijn van de vliezen te beschouwen. De frequentie-verdeling van de duur van het gebroken zijn van de vliezen is weergegeven in de tabellen 14 en 15 voor groep $\mathrm{K}$ respectievelijk groep $\mathrm{L}$.

Tabel 14: Frequentieverdeling van de duur van het gebroken zijn van de vliezen in de groep met minder dan of gelijk aan 24 uur gebroken vliezen (groep $K$ ) en het percentage ten opzichte van de gehele groep $K$.

\begin{tabular}{rrr} 
& $\begin{array}{r}\text { Groep K } \\
\text { Aantal registraties } \\
\mathrm{n}=3799\end{array}$ \\
\cline { 2 - 2 } duur gebroken vliezen & & $\%$ \\
(uren) & & \\
& & \\
$>00$ en $\leq 04$ & 994 & 26.2 \\
$>04$ en $\leq 08$ & 1594 & 42,0 \\
$>08$ en $\leq 12$ & 594 & 15,6 \\
$>12$ en $\leq 16$ & 294 & 7.7 \\
$>16$ en $\leq 20$ & 163 & 4,3 \\
$>20$ en $\leq 24$ & 86 & 2,3 \\
& 74 & 1,9 \\
\hline
\end{tabular}

Uit tabel 14 blijkt dat in de groep met kortdurend gebroken vliezen, groep K, 68,2\% van de baringen binnen 4 uur plaatsvindt. 
Tabel 15: Frequentieverdeling van de duur van hes gebroken zijn van de vliezen in de groep met langdurig gebroken vliezen (groep $L$ ) en het percentage ten opzichte van de gehele groep $L$.

\begin{tabular}{|c|c|c|}
\hline \multirow[b]{2}{*}{$\begin{array}{l}\text { duur gebroken } \\
\text { vliczen (uren) }\end{array}$} & $\begin{array}{r}\text { Groep L } \\
\text { Aantal registraties } \\
n=3870\end{array}$ & $\%$ \\
\hline & & \\
\hline$>024$ en $\leq 048$ & 2434 & 62,9 \\
\hline$>048$ en $\leq 096$ & 563 & 14.5 \\
\hline$>096$ en $\leq 144$ & 127 & 3,3 \\
\hline$>144$ en $\leq 192$ & 61 & 1.6 \\
\hline$>192$ en $\leq 240$ & 43 & 1.1 \\
\hline$>240 \mathrm{en} \leq 288$ & 52 & 1.3 \\
\hline$>288$ en $\leq 336$ & 17 & 0.4 \\
\hline$>366$ en $\leq 384$ & 14 & 0.4 \\
\hline$>384$ en $\leq 432$ & 10 & 0,3 \\
\hline$>432$ en $\leq 480$ & 7 & 0.2 \\
\hline$>480$ en $\leq 528$ & 11 & 0.3 \\
\hline$>528$ cn $\leq 576$ & 4 & 0.1 \\
\hline$>576$ en $\leq 624$ & 4 & 0.1 \\
\hline$>624$ en $\leq 672$ & 5 & 0.1 \\
\hline$>672$ en $\leq 720$ & 20) & 0.5 \\
\hline$>720$ en $\leq 768$ & 74 & 1.9 \\
\hline$>768$ en $\leq 816$ & 5 & 0.1 \\
\hline$>816$ en $\leq 864$ & 4 & 0.1 \\
\hline$>864$ en $\leq 912$ & 1 & 0.0 \\
\hline$>912$ en $\leq 960$ & 3 & 0.1 \\
\hline$>960$ en $\leq 999$ & 411 & 10.6 \\
\hline
\end{tabular}

In tabel 15 is te zien dat ruim $77 \%$ van de baringen met langdurig gebroken vliezen binnen 96 uur plaatsvindt.

Opvallend is dat bij 10,6\% van de patiënten de vliezen tussen de 960 en 999 uren gebroken zouden zijn. Nadere bestudering leert dat hier vrijwel steeds "999" werd aangegeven. Aangenomen moet worden dat hiermee bedoeld werd "onbekende duur".

De duur van het gebroken zijn van de vliezen wordt mogelijk beïnvloed door de zwangerschapsduur. Ter nadere bestudering wordt de zwangerschap verdeeld -en daarmee de populatie- in: de immature, de premature en de mature periode (tabel 16). 
hoofdstuk 4

Tabel 16: Het aantal registraties ingedeeld naar amenorroe en duur gebroken vliezen van de langdurig gebroken vliezen groep (groep $L$ ) en het percentage van het geheel binnen iedere amenorroeklasse op het moment van de baring.

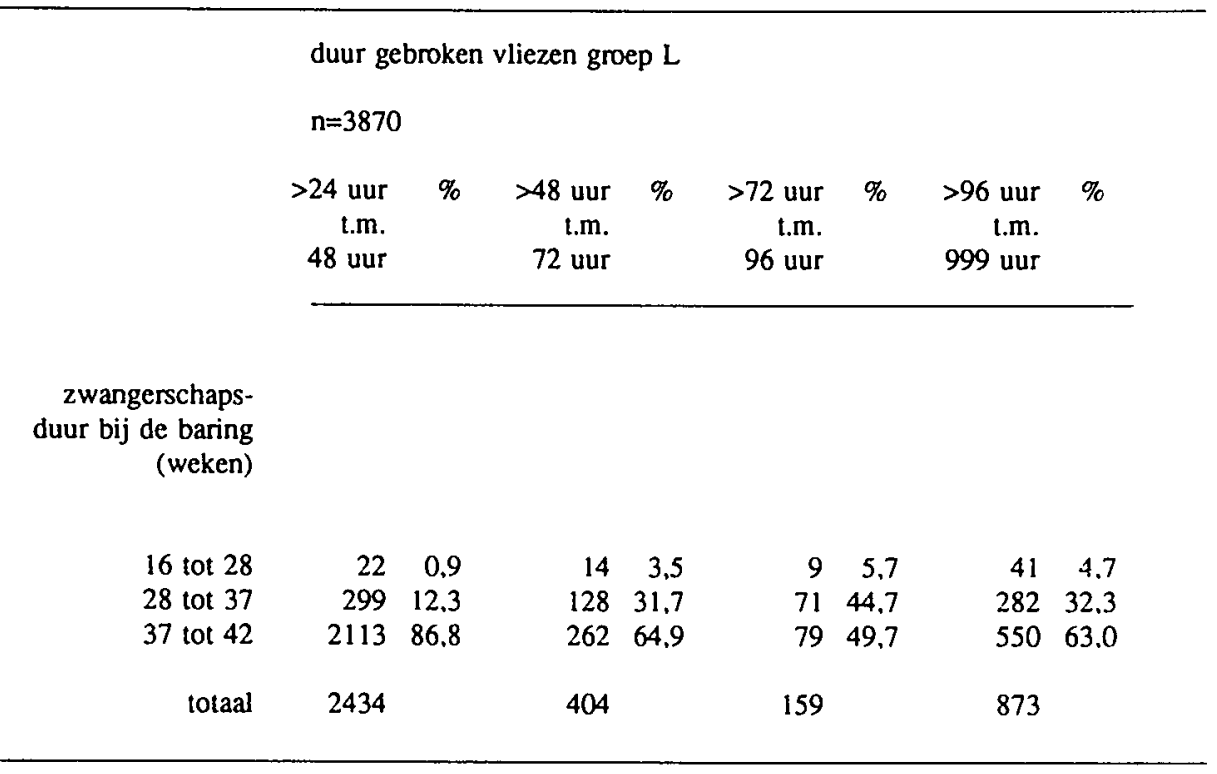

In tabel 16 is te zien dat er een verband is tussen de zwangerschapsduur en de duur van het gebroken zijn van de vliezen in de groep met langdurig gebroken vliezen (groep L). Met de toename van de latente periode is er een toename van het percentage registraties in de immature en premature periode ten opzichte van de mature periode. Dit geldt niet voor de periode van 96 tot en met 999 uur gebroken vliezen. Het aantal registraties in de groep tot en met 48 uur gebroken vliezen verschilt in alle amenorroeklassen significant ten opzichte van de groepen met langer dan 48 uur gebroken vliezen $(p<0,0001)$. Weeënremming respectievelijk weeënstimulering zal hierop onder andere van invloed zijn geweest. 


\subsubsection{Leeftijd van de moeder}

Ook de leeftijd van de moeder, in cohorten van 5 levensjaren, werd in dit onderzoek betrokken (tabel 17).

Tabel 17: De leeftijaisverdeling van de moeders in de groep met korter of gelijk aan 24 uur gebroken vliezen (K) en in de groep met langer dan 24 uur gebroken vliezen (L).

$\begin{array}{rr}\text { aantal registraties } & \text { aantal registraties } \\ \text { groep K } & \text { groep L } \\ n=3799 & n=3870\end{array}$

leeftijd

(jaren)

$>10$ en $\leq 15$

$>15$ en $\leq 20$

$>20$ en $\leq 25$

$>25$ en $\leq 30$

$>30$ en $\leq 35$

$>35$ en $\leq 40$

$>40$ en $\leq 45$

$>45$ en $\leq 50$

$>50$

$\begin{array}{rr}0 & 1 \\ 154 & 166 \\ 985 & 1044 \\ 1537 & 1625 \\ 868 & 825 \\ 214 & 188 \\ 40 & 19 \\ 1 & 2 \\ 0 & 0\end{array}$

De leeftijdsverdeling laat geen opvallende verschillen zien $(p=0,99)$.

\subsubsection{Langdurig gebroken vliezen en de zwangerschapsduur}

Uiteraard is ook de verdeling van de amenorroeduur in de groep met kortdurend gebroken vliezen en de groep met langdurig gebroken vliezen bestudeerd (tabel 18). 
hoofdstuk 4

Tabel 18: De verdeling naar zwangerschapsduur in weken in de beide onderzoeksgroepen ( $K$ en $L$ ).

\begin{tabular}{|c|c|c|}
\hline & $\begin{array}{r}\text { Aantal registraties } \\
\text { in groep K } \\
n=3799\end{array}$ & $\begin{array}{r}\text { Aantal registraties } \\
\text { in groep } L \\
n=3870\end{array}$ \\
\hline \multicolumn{3}{|l|}{$\begin{array}{r}\text { amenorroe } \\
\text { (weken) }\end{array}$} \\
\hline 16 & 1 & 2 \\
\hline 17 & 5 & 1 \\
\hline 18 & 4 & 4 \\
\hline 19 & 3 & 5 \\
\hline 20 & 6 & 3 \\
\hline 21 & 1 & 6 \\
\hline 22 & 7 & 12 \\
\hline 23 & 8 & 7 \\
\hline 24 & 7 & 7 \\
\hline 25 & 3 & 13 \\
\hline 26 & 7 & 12 \\
\hline 27 & 11 & 14 \\
\hline 28 & 7 & 17 \\
\hline 29 & 6 & 20 \\
\hline 30 & 13 & 22 \\
\hline 31 & 21 & 30 \\
\hline 32 & 19 & 62 \\
\hline 33 & 20 & 72 \\
\hline 34 & 41 & 129 \\
\hline 35 & 81 & 187 \\
\hline 36 & 137 & 241 \\
\hline 37 & 272 & 322 \\
\hline 38 & 549 & 546 \\
\hline 39 & 885 & 762 \\
\hline 40 & 1027 & 858 \\
\hline 41 & 605 & 471 \\
\hline 42 & 53 & 45 \\
\hline
\end{tabular}

Hoewel de samenstelling van de groep met kortdurend gebroken vliezen en de groep met langdurig gebroken vliezen als geheel niet significant verschilt $(p=0,67)$ is wel duidelijk dat in de groep met langer dan 24 uur gebroken vliezen veel meer patiënten voorkomen met een amenorroeduur van minder dan 37 weken. Dit wordt nog duidelijker wanneer een verdeling in de immature, de premature en de mature periode wordt gemaakt (tabel 19). Het verschil zal mede zijn bepaald door het al dan niet remmen of stimuleren van weeënactiviteit (paragraaf 4.3.1 en tabel 16). 
Tabel 19: De verdeling naar zwangerschapsduur, verdeeld in de immature, de premature en de mature periode.

$\begin{array}{lrr} & \begin{array}{r}\text { Aantal registraties } \\ \text { groep K } \\ n=3799\end{array} & \begin{array}{r}\text { Aantal registraties } \\ \text { groep L } \\ n=3870\end{array} \\ \text { amenorroe } & & \\ \text { (weken) } & & 86 \\ 28 \text { weken } & 63 & 780 \\ 37 \text { weken } & 345 & 3004 \\ 42 \text { weken } & 3391 & \end{array}$

Bij vergelijking van de samenstelling van de groepen $K$ en $L$ blijkt dat deze verschillen significant $(p<0,0009)$ zijn. Uit tabel 19 is ook af te leiden dat in de groep met langer dan 24 uur gebroken vliezen meer $(p<0,0001)$ premature baringen voorkomen dan in de groep met minder of gelijk aan 24 uur gebroken vliezen.

4.3.5 De duur van het gebroken zijn van de vliezen en de relatie met pariteit en amenorroeduur

In tabel 20 is de samenstelling weergegeven van de groep met kortdurend gebroken vliezen en de groep met langdurig gebroken vliezen, onderscheiden naar pariteit (primigravida of multigravida) en amenorroeduur.

Tabel 20: Het aantal primigravidae en multigravidae in beide groepen ( $K$ en $L$ ) ingedeeld in klassen van amenorroe.

\begin{tabular}{|c|c|c|c|c|}
\hline & $\begin{array}{l}\text { primi- } \\
\text { gravidae } \\
\text { groep } \mathrm{K}\end{array}$ & $\begin{array}{rr}\begin{array}{r}\text { multi- } \\
\text { gravidae }\end{array} \\
\text { groep K } \\
\mathrm{n}=3799 \quad\end{array}$ & $\begin{array}{l}\text { primi- } \\
\text { gravidae } \\
\text { groep L }\end{array}$ & $\begin{array}{r}\begin{array}{r}\text { multi- } \\
\text { gravidae } \\
\text { groep L }\end{array} \\
\mathrm{n}=3870 \quad \text {. }\end{array}$ \\
\hline \multicolumn{5}{|l|}{$\begin{array}{r}\text { amenorroe } \\
\text { (weken) }\end{array}$} \\
\hline$\geq 16$ en $<20$ & 1 & 12 & 3 & 9 \\
\hline 220 en $<24$ & 11 & 11 & 8 & 20 \\
\hline 224 en $<28$ & 10 & 18 & 5 & 41 \\
\hline 228 en $<32$ & 27 & 20 & 28 & 61 \\
\hline 232 en $<36$ & 78 & 83 & 211 & 239 \\
\hline 236 en $\leq 42$ & 1408 & 2120 & 1801 & 1444 \\
\hline totaal & 1535 & 2264 & 2056 & 1814 \\
\hline
\end{tabular}


hoofdstuk 4

In tabel 21 is de onderverdeling voor wat betreft de amenorroeduur beperkt tot de immature, premature en mature periode.

Tabel 21: Het aantal primigravidae en multigravidae in beide groepen ( $K$ en $L$ ) verdeeld in de immature. premature en mature periode.

\begin{tabular}{|c|c|c|}
\hline & $\begin{array}{r}\text { groep K } \\
\mathrm{n}=3799 \\
\text { primi- } \\
\text { gravidae }\end{array}$ & $\begin{array}{r}\text { groep L } \\
\mathrm{n}=3870 \\
\text { primi- } \\
\text { gravidac }\end{array}$ \\
\hline \multicolumn{3}{|l|}{$\begin{array}{r}\text { amenorroe } \\
\text { (weken) }\end{array}$} \\
\hline $\begin{array}{l}16 \text { tot } 28 \text { weken } \\
28 \text { tot } 37 \text { weken } \\
37 \text { tot } 42 \text { weken }\end{array}$ & $\begin{array}{r}22 \\
166 \\
1347\end{array}$ & $\begin{array}{r}16 \\
357 \\
1683\end{array}$ \\
\hline \multirow[t]{2}{*}{ totaal } & 1535 & 2056 \\
\hline & $\begin{array}{r}\text { groep K } \\
\text { multi- } \\
\text { gravidae }\end{array}$ & $\begin{array}{r}\text { groep L } \\
\text { multi- } \\
\text { gravidae }\end{array}$ \\
\hline \multicolumn{3}{|l|}{$\begin{array}{r}\text { amenorroe } \\
\text { (weken) }\end{array}$} \\
\hline 16 tot 28 weken & 41 & 70 \\
\hline 28 tot 37 weken & 179 & 423 \\
\hline 37 tot 42 weken & 2044 & 1321 \\
\hline totaal & 2264 & 1814 \\
\hline
\end{tabular}

Bij vergelijking van de samenstelling van de groepen $\mathrm{K}$ en $\mathrm{L}$ bij de primigravidae in de drie amenorroegroepen blijkt dat deze niet significant verschillend zijn $(p=0,09)$.

Uit tabel 21 blijkt evenwel ook dat in het geheel meer primigravidae $(p<0,0001)$ voorkomen in de groep met langdurig gebroken vliezen. Het percentage multigravidae in de verschillende amenorroegroepen verschilt wel significant $(p<0,0001)$. Bij de multigravidae komt het langdurig gebroken zijn van de vliezen vaker $(p<0,01)$ voor in de periode van 16 tot 37 weken amenorroe. In de periode van 37 tot 42 weken daarentegen komen meer $(p<0,0001)$ multigravidae voor in de groep met kortdurend gebroken vliezen. 
Het is denkbaar dat een verband te leggen is tussen het aantal graviditeiten dat een patiënte heeft doorgemaakt en het voortijdig breken van de vliezen (paragraaf 2.2). Dit verband werd nader bestudeerd (tabel 22).

Tabel 22: De verdeling van het aantal registraties naar het aantal zwangerschappen (inclusief de huidige) in de groep met kortdurend en de groep met langdurig gebroken vliezen (K en $L$ ).

\begin{tabular}{rrr}
\hline & $\begin{array}{r}\text { Aantal registra- } \\
\text { ties groep K } \\
\mathrm{n}=3799\end{array}$ & $\begin{array}{r}\text { Aantal registra- } \\
\text { ties groep L } \\
\mathrm{n}=3870\end{array}$ \\
\cline { 2 - 4 } $\begin{array}{r}\text { aantal } \\
\text { zwanger- }\end{array}$ & & \\
schappen & & \\
& & \\
1 & $1535(40 \%)$ & \\
2 & 1193 & $2056 \quad(53 \%)$ \\
3 & 628 & 980 \\
4 & 235 & 482 \\
5 & 113 & 195 \\
6 & 49 & 82 \\
7 & 18 & 37 \\
8 & 13 & 16 \\
9 & 9 & 9 \\
10 & 4 & 6 \\
11 & 1 & 5 \\
30 & & 2 \\
& 1 & 0 \\
\hline
\end{tabular}

Uit tabel 22 kan worden geconcludeerd, evenals uit tabel 21 , dat significant meer primigravidae voorkomen in de groep met langdurig gebroken vliezen $(p<0,0001)$. Een voor de hand liggende verklaring is de tragere ontsluiting bij een primigravida.

De aantallen die betrekking hebben op multigravidae ( $>1$ graviditeit doorgemaakt) werden statistisch bewerkt met de chi-kwadraat test voor een lineaire trend. Geen significante verschillen worden gevonden tussen de groepen $\mathrm{K}$ en $\mathrm{L}$. In dit onderzoek wordt geen verband aangetoond tussen het aantal doorgemaakte zwangerschappen bij multigravida en het langdurig gebroken zijn van de vliezen.

De conclusie moet luiden: het langdurig gebroken zijn van de vliezen komt bij primigravidae significant vaker voor. Zowel bij primigravidae als multigravidae komen langdurig gebroken vliezen met name voor in de premature periode. 
hoofdstuk 4

Als mogelijke oorzaken voor dit laatste zijn te noemen:

- de baring komt in het premature tijdperk langzamer op gang (figuur 1)

- de foetus wordt bedreigd door een premature baring, daarom zal worden getracht de baring uit te stellen.

\subsubsection{Voorafgaande manipulaties aan de cervix uteri}

Het voortijdig breken van de vliezen is mogelijk een gevolg van voorafgaande manipulatie aan de cervix (paragraaf 2.2). Hieronder worden niet alleen verstaan een curettage maar ook proefbiopten en een cervixcerclage. Wordt naar de anamnese gekeken, dan blijkt dat de Nederlandse cijfers, wat betreft het aantal abortus (spontaan of arte provocatus), waarbij veelal dilatatie van de cervix plaatsvindt het volgende beeld geven (tabel 23):

Tabel 23: Overzicht van het aantal abortus in de voorgeschiedenis in groep $K$ en $L$.

\begin{tabular}{rrr}
\hline & $\begin{array}{r}\text { Aantal } \\
\text { registraties } \\
\text { groep K } \\
\mathrm{n}=3799\end{array}$ & $\begin{array}{r}\text { Aantal } \\
\text { registraties } \\
\text { groep L } \\
\mathrm{n}=3870\end{array}$ \\
\cline { 2 - 3 } aantal & & \\
abortus & & \\
& & \\
0 & 1641 & 1755 \\
1 & 583 & 553 \\
2 & 164 & 144 \\
3 & 37 & 43 \\
4 & 14 & 14 \\
5 & 5 & 2 \\
6 & 1 & 0 \\
7 & 0 & 2 \\
\hline
\end{tabular}

Uit tabel 23 kan worden geconcludeerd dat patiënten met langdurig gebroken vliezen niet vaker een abortus, spontaan of arte provocatus, in de anamnese hebben. Helaas kan uit de S.I.G.-gegevens geen betrouwbare informatie worden verkregen betreffende andere vormen van manipulatie aan de cervix (paragraaf 4.2). 


\subsubsection{Inleiding van de baring}

Het aantal inleidingen en primaire sectiones caesareae in groep $\mathrm{L}$ is 1308 , in groep $\mathrm{K}$ 911. Het verschil is significant $(p<0,0001)$. Anderzijds blijkt dat in de groep met langdurig gebroken vliezen bij 66,2\% (2562 patiënten) is gewacht met ingrijpen: althans er is noch ingeleid noch een primaire sectio caesarea verricht. Als onder ingrijpen ook het toedienen van oxytocine of prostaglandine, zonder uitdrukkelijke vermelding van "inleiding", wordt begrepen is dit percentage lager (38\%), maar nog steeds aanzienlijk. In Nederland geldt dit ook voor de à terme periode: bij langdurig gebroken vliezen wordt niet altijd ingegrepen in de zin van inleiding of primaire sectio caesarea.

\section{Conclusie}

Weliswaar wordt, blijkens de gegevens van de S.I.G., bijna een kwart van de baringen ingeleid, bij langdurig gebroken vliezen wordt dit niet zelden nagelaten $(37,7 \%$ in de à terme periode).

Tabel 24 laat een overzicht van het aantal inleidingen en het aantal primaire sectiones caesareae zien. Ook de indicatie tot de inleiding of primaire sectio caesarea is weergegeven.

Tabel 24: Overzicht van het aantal inleidingen in de groepen ( $K$ en $L$ ) en de indicaties tol een selectieve primaire sectio caesarea of een selectieve inleiding in beide groepen.

$\begin{array}{rrr} & \begin{array}{r}\text { Grocp K } \\ n=911\end{array} & \begin{array}{r}\text { Grocp L } \\ n=1308\end{array} \\ & & \\ \text { soor } & & 383 \\ \text { electief } & 358 & 925\end{array}$

indicatic voor het selectief inleiden of het verrichten van een primaire sectio caesarea

$\begin{array}{rrr}\text { conditie kind } & 228 & 410 \\ \text { conditic moeder } & 150 & 95 \\ \text { conditie moeder en kind } & 175 & 420 \\ & & \\ \text { totaal } & 553 & 925\end{array}$


hoofdstuk 4

In tabel 24 wordt onder electieve inleiding verstaan het aantal inleidingen waarvoor geen medische indicatie bestond. Onder een selectieve inleiding wordt verstaan een inleiding waarvoor een medische reden bestond.

Uit tabel 24 kan worden geconcludeerd dat in de groep met langdurig gebroken vliezen veel vaker selectief wordt ingeleid dan in de groep met kortdurend gebroken vliezen $(p<0,0001)$. Dit verschil is niet onverwacht.

\subsubsection{Liggingsafwijkingen}

Zoals vermeld is in paragraaf 2.2 wordt bij de etiologie van het voortijdig breken van de vliezen ook steeds de afwijkende ligging genoemd; een causaal verband wordt betwijfeld. Het frequenter voorkomen van liggingsafwijkingen is geen oorzaak maar zeer waarschijnlijk gevolg van het bevallen in de immature of premature periode. De S.I.G.-gegevens over 1985 betreffende de liggingsafwijkingen laten het volgende zien (tabel 25):

Tabel 25: De frequentieverdelingen van de verschillende liggingen in de groep met korter of gelijk aan 24 uur gebroken vliezen (groep $K$ ) en in de groep met langer dan 24 uur gebroken vliezen (groep $L$ ) en hel percentage dat elk cohort vertegenwoordigt binnen de gehele groep.

\begin{tabular}{rrrrr}
\hline & $\begin{array}{r}\text { Groep K } \\
\mathrm{n}=3799\end{array}$ & $\%$ & $\begin{array}{c}\text { Groep L } \\
\mathrm{n}=3870\end{array}$ & $\%$ \\
\cline { 2 - 4 } ligging & & & & \\
achterhoofdsligging & 3240 & 85.3 & 3382 & 87.4 \\
kruinligging & 107 & 2.8 & 132 & 3.4 \\
aangezichtsligging & 10 & 0.3 & 10 & 0.3 \\
hoofdligging anders & 47 & 1.2 & 54 & 1.4 \\
dwarsligging & 24 & 0.6 & 18 & 0.5 \\
volkomen stuitligging & 92 & 2.4 & 71 & 1.8 \\
onvolkomen stuitligging & 237 & 6.2 & 162 & 4.2 \\
stuitligging anders & 24 & 0.6 & 13 & 0.3 \\
overige & 3 & 0.1 & 10 & 0.3 \\
onbekend & 15 & 0.4 & 18 & 0.5 \\
\hline
\end{tabular}

Liggingsafwijkingen komen bij langdurig gebroken vliezen dus niet vaker voor. Stuitliggingen komen in de groep met kortdurend gebroken vliezen merkwaardigerwijs vaker $(\mathrm{p}<0,001)$ voor. 


\subsubsection{Kunstverlossingen}

De S.I.G.-gegevens over 1985 tonen wat de kunstverlossingen betreft het volgende (tabel 26):

Tabel 26: Het aantal kunstverlossingen in de groep met korter of gelijk aan 24 uur gebroken vliezen (K) in de groep met langer dan 24 uur gebroken vliezen $(L)$.

\begin{tabular}{rrr}
\hline & $\begin{array}{r}\text { Groep K } \\
n=3799\end{array}$ & $\begin{array}{r}\text { Groep L } \\
\mathrm{n}=3870\end{array}$ \\
\cline { 2 - 3 } & & \\
soort kunstverlossing & & \\
vacuümextractie & 320 & 399 \\
forcipale extractie & 181 & 168 \\
versie en extractic & 1 & 6 \\
probleem bij schouders & 48 & 10 \\
probleem nakomend hoofd & 7 & 8 \\
primaire stuitextractic & 15 & 373 \\
secundaire sectio caesarea & 223 & 15 \\
overige & 11 & 92 \\
onbekend & 173 & 1100 \\
totaal & & \\
\hline
\end{tabular}

In de groep met langdurig gebroken vliezen wordt in het algemeen niet vaker een kunstverlossing verricht. Bij onderverdeling blijkt dat bij langdurig gebroken vliezen vaker dan bij kortdurend gebroken vliezen een vacuümextractie $(p<0,01)$ of sectio caesarea $(p<0,001)$ wordt verricht.

\subsubsection{Geslacht van de geboren kinderen}

Het "Respiratory Distress Syndrome" komt bij jongens die prematuur worden geboren vaker voor dan bij meisjes (paragraaf 2.4). Ook is het denkbaar dat de foetus een rol speelt bij het voortijdig breken van de vliezen (paragraaf 2.2 ). De mortaliteit en morbiditeit zouden dan ook kunnen worden beïnloed doordat de geslachtsverdeling in de groepen niet gelijk is. In de S.I.G.-gegevens is de ratio jongens/meisjes 1,18; dit geldt voor de gehele groep. Voor de groep met langdurig gebroken vliezen voor de $37^{\mathrm{c}}$ week, is de ratio 1,30; het verschil met de gehele groep is significant $(p<0,001)$. In de groep met kortdurend gebroken vliezen is dit verschil voor de $37^{*}$ week ten opzichte van de gehele groep met kortdurend gebroken vliezen iets minder duidelijk, ratio 1,27, maar nog steeds significant $(p<0,02)$. 
hoofdstuk 4

Concluderend kan worden gesteld: er is geen duidelijk verschil gevonden tussen de twee groepen (K en L) wat de geslachtsverdeling van de geboren kinderen betreft. Wel worden in de premature periode significant meer jongens geboren.

\subsubsection{Geboortegewichten}

Het geboortegewicht van een pasgeborene kan een weerspiegeling zijn van de situatie van het kind in de uterus. Evenwel het geboortegewicht alleen heeft een beperkte waarde. De percentielen, waarbij de relatie geboortegewicht/zwangerschapsduur tot uiting komt, geven de intra-uteriene groei van het kind beter weer. De onderzochte groepen ( $\mathrm{K}$ en $\mathrm{L}$ ) werden vergeleken met de Amsterdamse groeicurven (Arts en Kloosterman 1985). De verdeling van de percentielen wordt gegeven in tabel 27.

Tabel 27: De indeling van het geboortegewicht in klassen van percentielen in de groep met kortdurend (K) en langdurig (L) gebroken vliezen.

\begin{tabular}{|c|c|c|}
\hline & $\begin{array}{r}\text { Groep K } \\
n=3799\end{array}$ & $\begin{array}{r}\text { Groep L } \\
n=3870\end{array}$ \\
\hline \multicolumn{3}{|l|}{ Percentiel } \\
\hline$>0,0$ en $<2,3$ & 81 & 57 \\
\hline$\geq 2,3$ en $<5,0$ & 118 & 66 \\
\hline$\geq 5,0$ en $<10,0$ & 190 & 160 \\
\hline$\geq 10,0$ en $<25,0$ & 532 & 521 \\
\hline$\geq 25.0$ en $<50,0$ & 881 & 957 \\
\hline$\geq 50,0$ en $<75,0$ & 903 & 954 \\
\hline$\geq 75,0$ en $<90,0$ & 572 & 623 \\
\hline$\geq 90,0$ en $<95,0$ & 201 & 220 \\
\hline$\geq 95.0 \mathrm{en}<97.7$ & 158 & 130 \\
\hline$>97.7$ & 116 & 128 \\
\hline onbekend & 47 & 54 \\
\hline
\end{tabular}

De verdeling van de kinderen over de percentielklassen blijkt in beide groepen niet significant verschillend te zijn. Wel komen dysmature kinderen (in dit onderzoek gedefinieerd als geboortegewichten onder de $2,3^{\mathrm{e}}$ percentiel) in de groep met langdurig gebroken vliezen minder vaak $(p<0,04)$ voor dan in de groep met kortdurend gebroken vliezen. Een verklaring hiervoor zou kunnen zijn het eerder inleiden van de baring bij het vermoeden op groeiachterstand.

Macrosomie (gedefinieerd als het geboortegewicht groter dan de $97,7^{\mathrm{e}}$ percentiel) komt niet vaker voor bij langdurig gebroken vliezen. 


\section{Conclusie}

Bij langdurig gebroken vliezen komt noch dysmaturitas noch macrosomie frequenter voor.

\subsubsection{Neonatale morbiditeit}

Zoals eerder is vermeld, ontbreken helaas betrouwbare gegevens over het voorkomen van R.D.S. en neonatale infecties. Uit de S.I.G.-gegevens kunnen slechts Apgarscore en ziekenhuisverblijf van de pasgeborene, als afspiegeling van neonatale morbiditeit, als betrouwbare parameter worden verkregen.

De betekenis van de Apgarscore, als parameter voor de morbiditeit op langere termijn, is echter tenminste omstreden (M. Dijxhoorn, 1986). Tabel 28 geeft een overzicht van de Apgarscore in beide groepen.

Tabel 28: De verdeling in klassen van Apgarscores na vijf minuten in de onderzoeksgroepen $K$ en $L$.

Groep K
$n=3799$$\quad \begin{array}{r}\text { Groep L } \\ n=3870\end{array}$

Apgarscore

$\begin{array}{rrr}\geq 00 \text { en } \leq 04 & 103 & 113 \\ >04 \text { en } \leq 06 & 39 & 67 \\ >07 \text { en } \leq 08 & 229 & 350 \\ >09 \text { en } \leq 10 & 3401 & 3319 \\ \text { onbekend } & 27 & 21\end{array}$

De procentuele verdeling van de apgarscore binnen de groep met kortdurend gebroken vliezen vergeleken met die in de groep met langdurig gebroken vliezen is niet significant verschillend.

In de groep met langdurig gebroken vliezen werden vaker $(p<0,0001)$ kinderen geboren met een lage ( $\leq 8)$ Apgarscore na 5 minuten.

De duur en de plaats van het verblijf in het ziekenhuis van het kind zijn weergegeven in tabel 29. 
Tabel 29: Ziekenhuisverblijf en pediatrische zorg in de groep met kortdurend $(K)$ respectievelijk langdurig $(L)$ gebroken viiezen.

\begin{tabular}{rrr} 
& $\begin{array}{r}\text { Groep K } \\
n=3799\end{array}$ & $\begin{array}{r}\text { Groep L } \\
n=3870\end{array}$ \\
\cline { 2 - 3 } verblijf in ziekenhuis & & \\
$\leq 2$ dagen na geboorte & & 1423 \\
naar huis & 1943 & \\
$>2$ dagen in ziekenhuis & 990 & 978 \\
met de moeder & 611 & 1130 \\
naar pediatrie acuut & 139 & 214 \\
naar pediater later & 116 & 125 \\
onbekend & &
\end{tabular}

De samenstelling van de groepen $\mathrm{K}$ en $\mathrm{L}$ zijn bij vergelijking met de chi-kwadraattest significant verschillend $(\mathrm{p}<0,004)$.

Kinderen die na langdurig gebroken vliezen werden geboren gingen later $(p<0,0001)$ naar huis en moesten zich vaker $(p<0,0001)$ pediatrische zorg laten welgevallen.

Tevens werd onderzocht of een dergelijk verschil ook tot uiting komt in het "met de moeder mee naar huis gaan". Hiermee wordt gedoeld op het ziekenhuisverblijf van de pasgeborene (tabel 30).

Tabel 30: De verdeling van het aantal kinderen dat al dan niet met de moeder het ziekenhuis verlaat in de groepen $K$ en $L$.

\begin{tabular}{rrr} 
& $\begin{array}{r}\text { Groep K } \\
n=3799\end{array}$ & $\begin{array}{r}\text { Groep L } \\
n=3870\end{array}$ \\
\cline { 2 - 2 } conditie kind & & \\
mee naar huis & 3133 & 2787 \\
niet mee naar huis & 387 & 733 \\
onbekend & 279 & 350
\end{tabular}

De samenstelling van de groep met kortdurend gebroken vliezen verschilt significant ten opzichte van de groep met langdurig gebroken vliezen $(p<0,02)$. Uit tabel 30 blijkt dat in groep $L$ significant minder kinderen met de moeder het ziekenhuis verlaten.

Uit tabel 29 en tabel 30 blijkt tevens dat bij langdurig gebroken vliezen er een grotere $(p<0,0001)$ kans is dat het kind langdurig van de moeder wordt gescheiden. 


\subsubsection{Perinatale mortaliteit}

De verdeling over de twee groepen laat de volgende tabel zien:

Tabel 31: De verdeling naar het tijdstip van het overlijden van de kinderen in de groep met korter of gelijk aan 24 uur gebroken vliezen en de groep met langer dan 24 uur gebroken vliezen (groep $K$ en $L$ ).

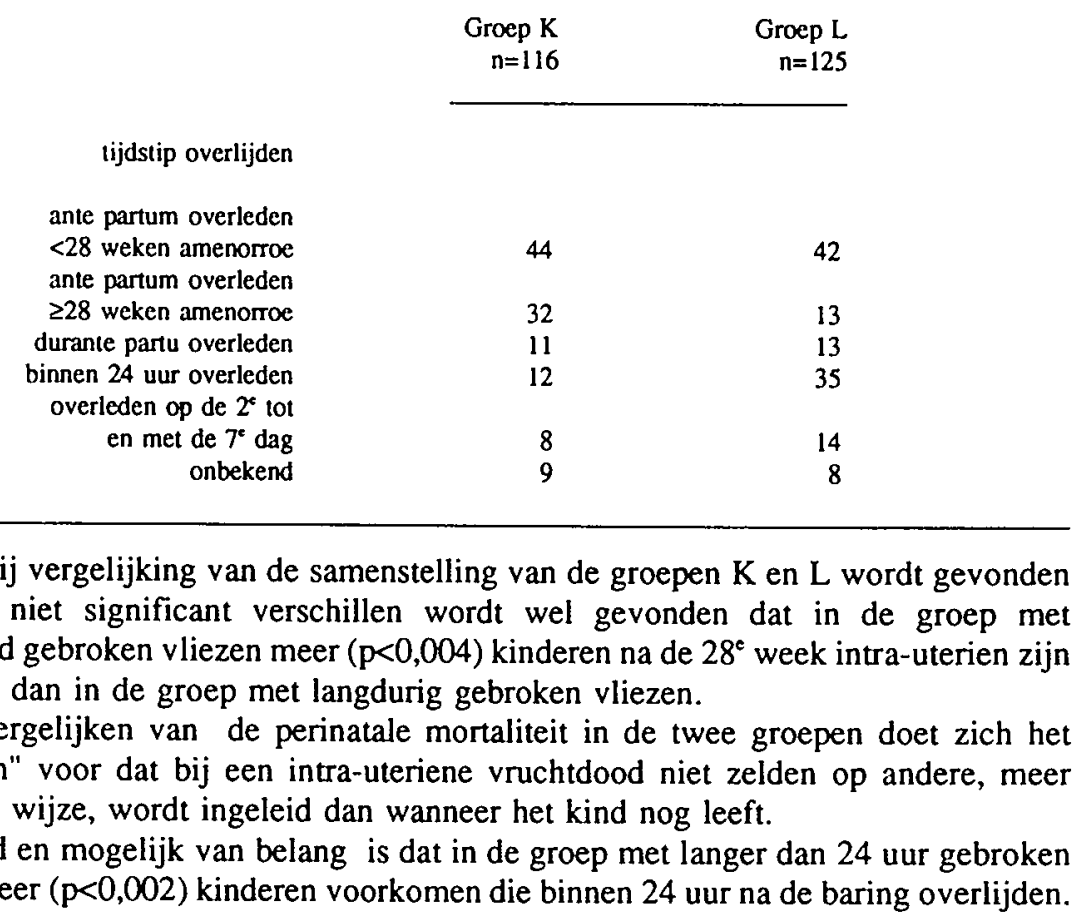

Hoewel bij vergelijking van de samenstelling van de groepen $\mathrm{K}$ en $\mathrm{L}$ wordt gevonden dat deze niet significant verschillen wordt wel gevonden dat in de groep met kortdurend gebroken vliezen meer $(p<0,004)$ kinderen na de $28^{c}$ week intra-uterien zijn overleden dan in de groep met langdurig gebroken vliezen.

Bij het vergelijken van de perinatale mortaliteit in de twee groepen doet zich het "probleem" voor dat bij een intra-uteriene vruchtdood niet zelden op andere, meer effectieve wijze, wordt ingeleid dan wanneer het kind nog leeft.

Opvallend en mogelijk van belang is dat in de groep met langer dan 24 uur gebroken vliezen meer $(p<0,002)$ kinderen voorkomen die binnen 24 uur na de baring overlijden.

\subsubsection{Morbiditeit en mortaliteit van de moeder}

De S.I.G.-gegevens die in dit kader bruikbaar zijn, zijn de kraambedgegevens, de duur van het verblijf in het ziekenhuis van de moeder en de moederlijke mortaliteit.

Als een van de uitingen van verhoogde morbiditeit bij de moeder werden de kraambedgegevens onderzocht. Hierbij werden geen opvallende verschillen gevonden (tabel 32). 
hoofdstuk 4

Tabel 32: Verloop van het kraambed in groep $K$ en $L$.

\begin{tabular}{rrr}
\hline & $\begin{array}{r}\text { Groep K } \\
n=3799\end{array}$ & $\begin{array}{c}\text { Groep L } \\
n=3870\end{array}$ \\
\cline { 2 - 3 } & & \\
verioop krambed & & \\
geen bijzonderheden & 2847 & 2863 \\
afwijkend & 289 & 339 \\
onbekend & 663 & 668 \\
\hline
\end{tabular}

Als uiting van maternale morbiditeit werd ook de duur van het ziekenhuisverblijf na de baring in de twee groepen vergeleken (tabel 33).

Tabel 33: Ziekenhuisverblijf van de moeder na de partus in de groep met kortdurend en de groep met langdurig gebroken vliezen (groep $K$ en $L$ ).

\begin{tabular}{rrr}
\hline & $\begin{array}{r}\text { Groep K } \\
\mathrm{n}=3799\end{array}$ & $\begin{array}{r}\text { Groep L } \\
n=3870\end{array}$ \\
\cline { 2 - 2 } & & \\
opnameduur & & \\
& & 521 \\
0 dagen & 574 & 841 \\
1 dag & 1185 & 478 \\
2 dagen & 488 & 285 \\
3 dagen & 216 & 198 \\
4 dagen & 117 & 147 \\
5 dagen & 109 & 180 \\
6 dagen & 133 & 342 \\
7 dagen & 305 & 878 \\
$>7$ dagen & 672 & \\
\hline
\end{tabular}

Bij vergelijking van de groep met kortdurend gebroken vliezen en de groep met langdurig gebroken vliezen bleek, wat betreft het ziekenhuisverblijf na de baring, dat er geen significant verschil was.

$\mathrm{Na}$ het langdurig gebroken zijn van de vliezen bleek de moeder wel vaker $(p<0,0001)$ langdurig (meer dan 3 dagen) in het ziekenhuis te moeten worden opgenomen.

Maternale sterfte: in de groep met langer dan 24 uur gebroken vliezen kwam geen maternale sterfte voor, in de groep met korter dan 24 uur gebroken vliezen werd één maal een maternale sterfte geregistreerd. 


\section{Conclusies}

1. Het breken van de vliezen voordat weeënaktiviteit optreedt komt frequent voor: zelfs in de groep met kortdurend gebroken vliezen is dit 15,5\%; in de groep met langdurig gebroken vliezen is dit uiteraard veel hoger.

2. Langdurig gebroken vliezen kwam procentueel in de immature en premature periode vaker voor dan in de mature periode.

3. De leeftijd van de moeder leek geen verband te hebben met langdurig gebroken vliezen.

4. Langdurig gebroken vliezen kwam vaker voor bij primigravida.

5. Geen verband werd aangetoond tussen een abortus (spontaan of arte provocatus) in de anamnese, als voorbeeld van manipulatie aan de cervix uteri, en langdurig gebroken vliezen.

6. Niet zelden werd het voorkómen van langdurig gebroken vliezen, door het inleiden van de baring of een sectio caesarea, nagelaten.

7. In de groep met langdurig gebroken vliezen kwamen niet meer afwijkende liggingen voor dan in de groep met kortdurend gebroken vliezen.

8. Bij langdurig gebroken vliezen werd vaker een vacuümextractie of een secundaire sectio caesarea verricht.

9. Er is geen verband gevonden tussen het breken van de vliezen en het geslacht van het kind. Wel werden in de premature periode significant meer jongens geboren.

10. Dysmaturitas (geboortegewicht kleiner dan de $2,3^{\mathrm{e}}$ percentiel volgens de Amsterdamse groeicurven) noch macrosomie (geboortegewicht groter dan de $97,7^{\circ}$ percentiel volgens de Amsterdamse groeicurven) kwamen vaker voor in de groep met langdurig gebroken vliezen.

11. De Apgarscore van de kinderen in de groep met langdurig gebroken vliezen is gemiddeld lager dan in de groep met minder of gelijk aan 24 uur gebroken vliezen.

12. In de groep met langdurig gebroken vliezen gingen binnen 2 dagen significant minder kinderen naar huis dan in de groep met kortdurend gebroken vliezen. 
hoofdstuk 4

13. In de groep met langdurig gebroken vliezen werden de kinderen door een langere ziekenhuisopname significant vaker van de moeder gescheiden.

14. Een verhoogde neonatale sterfte in de eerste 24 levensuren werd gevonden in de groep met langdurig gebroken vliezen.

15. Bij langdurig gebroken vliezen bleef de moeder ook na de baring langer in het ziekenhuis opgenomen.

\section{Discussie}

In de literatuur wordt vermeld dat tot en met 24 uur gebroken vliezen geen invloeden aan het gebroken zijn van de vliezen mogen worden verbonden. Toch zijn binnen die 24 uur zowel positieve als negatieve effecten van het gebroken zijn van de vliezen te noemen. Zo kan versnelde longrijping reeds na 6 uur gebroken vliezen optreden. Afweerreactie van de foetus worden beschreven (tegen infecties) die vóor het breken van de vliezen moeten zijn opgetreden. Voor de morbiditeit van de pasgeborene heeft dat consequenties en daarom moet de scheidingslijn van 24 uur gebroken vliezen arbitrair worden genoemd.

Uit groep $\mathrm{K}$ werden door de insluitcriteria 1091 patiëntenregistraties niet in het onderzoek opgenomen. In groep L waren er dat 1025. Insluitcriterium 3 (zekerheid van amenorroe) is door het onderzoek zelf gegeven. Insluitcriterium 1 ( $\geq 16$ weken amenorroe), insluitcriterium 3 ( $\leq 42$ weken amenorroe) en insluitcriterium 4 (alleen eenlingen werden in het onderzoek opgenomen) maakt dat de resultaten met enige voorzichtigheid dienen te worden bezien. Het feit dat uit beide groepen een vrijwel even groot aantal patiënten niet kon worden opgenomen in dit onderzoek, maakt dit voorbehoud mogelijk van minder belang. 


\section{Hoofdstuk 5}

\section{Nadelen van twijfel aan het gebroken zijn van de vliezen}

\subsection{Inleiding}

Indien aan het gebroken zijn van de vliezen wordt getwijfeld zal een patiënte mogelijk over- of onder worden behandeld. Deze over- of onderbehandeling op zich kan nadelig zijn. Om de mate van over- of onderbehandeling te inventariseren werden de Nederlandse gegevens van patiënten met kortdurend en langdurig gebroken vliezen vergeleken met de eigen onderzoeksgegevens van patiënten uit de enquêtegroep en de groep met dubieus gebroken vliezen. Verwacht mag worden dat, indien de incidentie van het werkelijk gebroken zijn van de vliezen in de twijfelgroep $50 \%$ is, de resultaten van de patiënten met dubieus gebroken vliezen tussen de resultaten van de patiënten met kortdurend en die met langdurig gebroken vliezen in liggen.

\subsection{Opzet van het onderzoek}

In de periode van 01-01-1986 tot 01-07-1986 werd in de eerder genoemde ziekenhuizen (paragraaf 3.2), bij twijfel aan het gebroken zijn van de vliezen, vaginaal afgelopen vocht onderzocht. Voor de uniforme registratie van de voor dit onderzoek meest relevante gegevens werd een speciaal formulier ontworpen (bijlage 6). In die periode werd bij 120 patiënten vocht verkregen.

Deze 120 patiënten vormden $8,2 \%$ van het totaal aantal baringen (1469 in genoemde periode in de klinieken die aan dit onderzoek deelnamen). Dit percentage is iets hoger dan het eerder genoemde percentage van de enquêtegroep: 5,7\% (aantal patiënten waarbij een enquêteformulier werd ingevuld bij twijfel aan het gebroken zijn van de vliezen). In de gehele onderzoeksperiode (01-01-1985 tot 01-07-1986) werd dus bij één op de vijtien patiënten die in de deelnemende klinieken bevielen, op enig moment tijdens de zwangerschap aan het gebroken zijn van de vliezen getwijfeld. Dit is derhalve een frequent voorkomend probleem. 
hoofdstuk 5

\subsection{Resultaten van het onderzoek}

5.3.1 Kenmerken van de groep met dubieus gebroken vliezen waarbij vocht werd verzameld

Van 4 van de 120 patiënten waren geen klinische gegevens beschikbaar. Derhalve was het mogelijk om de klinische gegevens van 116 patiënten voor dit gedeelte van het onderzoek te bewerken.

De gemiddelde leeftijd van de patiënten met dubieus gebroken vliezen was 26,8 jaar. Dit is vergelijkbaar met de gemiddelde leeftijd van de enquêtegroep ( 27 jaar). De groep met dubieus gebroken vliezen waarbij vocht werd verzameld bevat 58 primigravidae en 58 multigravidae. Deze verdeling is procentueel identiek met die in de enquêtegroep.

De amenorroeduur, op het moment van de eerste uiting van de klacht, laat het volgende beeld zien (tabel 34 ):

Tabel 34: Overzicht van de amenorroeduur op het moment van de klacht en het aantal patiënten.

\begin{tabular}{rrr}
\hline & $\begin{array}{r}\text { Aantal } \\
n=116\end{array}$ & $\begin{array}{r}\text { Percentage } \\
(\%)\end{array}$ \\
\cline { 2 - 2 } amenorroe & & \\
(weken) & & \\
$\geq 16$ en $<20$ & & 2.6 \\
$\geq 20$ en $<24$ & 3 & 5.2 \\
$\geq 24$ en $<28$ & 2 & 1,7 \\
$\geq 28$ en $<32$ & 7 & 6.0 \\
$\geq 32$ en $<36$ & 22 & 19.0 \\
$\geq 36$ en $\leq 42$ & 76 & 65.5 \\
\end{tabular}

Net als in de enquêtegroep was het ook in deze groep opvallend dat een aantal patiënten laat hulp zoekt (tabel 35). 
nadelen van twijfel

Tabel 35: Overzicht van het tijdsverloop tussen het optreden van de klacht en het zoeken van hulp in de groep met dubieus gebroken vliezen.

\begin{tabular}{rrr}
\hline & $\begin{array}{r}\text { Aantal } \\
\mathrm{n}=116\end{array}$ & $\begin{array}{r}\text { Percentage } \\
(\%)\end{array}$ \\
\cline { 2 - 3 } & & \\
duur van de klacht & & \\
(dagen) & & 83,6 \\
01 & 97 & 5,2 \\
02 & 6 & 3,4 \\
03 & 4 & 0,0 \\
04 & 0 & 0,9 \\
05 & 1 & 0,0 \\
06 & 0 & 2.6 \\
07 & 3 & 4,3 \\
$>07$ & 5 & \\
\hline
\end{tabular}

Uit de groep met dubieus gebroken vliezen werden 73 patiënten opgenomen (63\%), 38 werden poliklinisch vervolgd (33\%) en 5 patiënten waren reeds opgenomen (4\%). Dat betekent dat $67 \%$ van de patiënten, met dubieus gebroken vliezen, verder klinisch werden geobserveerd. Dit percentage lijkt hoger dan dat in de enquêtegroep (59\%), maar het verschil is niet significant.

5.3.2 Vergelijking van de groep met kortdurend gebroken vliezen (S.I.G.), dubieus gebroken vilezen samen met de enquêtegroep (eigen onderzoek) en de groep met langer dan 24 uur gebroken vliezen (S.I.G.)

Voor de vergelijking van de klinische gegevens kunnen twee groepen worden samengevoegd: de enquêtegroep en de groep met dubieus gebroken vliezen. Bij beide groepen wordt immers getwijfeld aan het gebroken zijn van de vliezen. Het "verschil" tussen de twee groepen is dat de enquêtegroep alleen is gebruikt ter inventarisatie van de grootte van het probleem dubieus gebroken vliezen; bij de zogenaamde groep "dubieus gebroken vliezen" is ook vocht verzameld om de diagnose staande of gebroken vliezen, te stellen. De twee groepen samen kunnen worden gebruikt om het effect van het mogelijk gebroken zijn van de vliezen op moeder en kind te bestuderen. 
hoofdstuk 5

Drie groepen kunnen aldus onderscheiden en worden vergeleken:

1. De S.I.G-groep met kortdurend gebroken vliezen is bevallen in 1985 (de aselecte steekproef, $n=3799$ ). Deze groep wordt groep $K$ genoemd (identiek aan groep $K$ in hoofdstuk 4).

2. De groep met dubieus gebroken vliezen (166 patiènten) samen met de enquêtegroep (116 patiënten), exclusief meerlingen $(n=9)$, de groep patiënten die vergelijkbaar is met de S.I.G.-groepen: 273 patiënten. Verzamelperiode: 01-01-1985 tot 01-07-1986. Deze groep wordt groep D genoemd.

3. De groep met langdurig gebroken vliezen ( $n=3870$ ), geselecteerd door het S.I.G. eveneens met behulp van gegevens verkregen in 1985 (hoofdstuk 4). Deze groep wordt L genoemd en is identiek aan de gelijknamige groep in hoofdstuk 4.

De gemiddelde leeftijd in de drie groepen verschilt niet significant (respectievelijk 27,4 jaar, 26,9 jaar en 27,7 jaar). Ook het gemiddeld aantal doorgemaakte graviditeiten verschilt niet significant (respectievelijk $1,9,2,3$ en 2,1 ).

Verwacht mag worden dat de groep waarbij wordt getwijfeld aan het staan van de vliezen qua morbiditeit en mortaliteit van moeder en kind zich "bevindt" tussen de groep met kortdurend gebroken vliezen en de groep met langdurig gebroken vliezen. Aangenomen wordt immers dat na 24 uur de kans op complicaties van langdurig gebroken vliezen toeneemt (paragraaf 2.4). De volgende morbiditeitsitems werden bestudeerd:

- vroeggeboorten

- liggingsafwijkingen

- kunstverlossingen

- dysmaturiteit

- neonatale morbiditeit

- perinatale mortaliteit

- morbiditeit van de moeder.

\subsubsection{Vroeggeboorten}

In tabel 36 is de verdeling van de amenorroeduur weergegeven in de drie groepen. 
Tabel 36: Amenorroeduur bij de baring in de groepen $K, D$ en $L$ en het percentage ten opzichte van de gehele groep.

\begin{tabular}{rrrrrrr}
\hline & $\begin{array}{r}\text { groep K } \\
\mathrm{n}=3799\end{array}$ & $\%$ & $\begin{array}{r}\text { groep D } \\
\mathrm{n}=273\end{array}$ & $\%$ & $\begin{array}{r}\text { groep L } \\
\mathrm{n}=3870\end{array}$ & $\%$ \\
\cline { 2 - 6 } & & & & & & \\
amenorroe & & & & & & \\
(weken) & 13 & 0,3 & 4 & 1,5 & 12 & 0,3 \\
& 22 & 0,6 & 5 & 1,8 & 28 & 0,7 \\
$16 \cot 20$ & 28 & 0,7 & 3 & 1,1 & 46 & 1,2 \\
20 tot 24 & 47 & 1,2 & 7 & 2,6 & 89 & 2,3 \\
24 tot 28 & 161 & 4,2 & 20 & 7,3 & 450 & 11,6 \\
28 tot 32 & 3475 & 91,5 & 207 & 75,8 & 3200 & 82,7 \\
32 tot 36 & 53 & 1,4 & 27 & 9.9 & 45 & 1,2 \\
36 tot 42 & & & & & & \\
242 & & & & & & \\
\hline
\end{tabular}

In groep $D$, de groep van patiënten met dubieus gebroken vliezen, bevielen meer vrouwen in de immature periode dan in de groep met kortdurend of langdurig gebroken vliezen $(p<0,03)$.

In tabel 36 is te zien dat in groep D meer patiënten bevielen in de premature periode van 28 tot 37 weken, dan in de groep met kortdurend gebroken vliezen: respectievelijk 14,3 en $6,9 \%$. Dit verschil is significant $(p<0,004)$. Het verschil met de groep met langdurig gebroken vliezen is niet significant.

Concluderend kan gesteld worden:

in groep D, de groep van patiënten met dubieus gebroken vliezen, bevielen significant meer patiënten in het immature en premature tijdperk vergeleken met de kortdurend gebroken vliezen groep (groep $\mathrm{K}$ ). In groep $\mathrm{D}$ bevielen ook significant meer patiënten in de immature periode dan in de groep met langdurig gebroken vliezen (groep L).

\subsubsection{Liggingsafwijkingen}

Tabel 37 geeft de verdeling van de ligging van de kinderen bij de geboorte. 
hoofdstuk 5

Tabel 37: De ligging van de kinderen bij de baring in de drie onderzoeksgroepen $K, D, L$.

\begin{tabular}{rrrrrrr}
\hline & $\begin{array}{r}\text { groep K } \\
\mathrm{n}=3799\end{array}$ & $\%$ & $\begin{array}{r}\text { groep D } \\
\mathrm{n=273}\end{array}$ & $\%$ & $\begin{array}{r}\text { groep L } \\
\mathrm{n=3870}\end{array}$ & $\%$ \\
\cline { 2 - 7 } ligging & & & & & & \\
schedelligging & 3404 & 89,6 & 250 & 91,6 & 3578 & 92,5 \\
dwarsligging & 24 & 0,6 & 1 & 0,4 & 18 & 0,5 \\
$\begin{array}{r}\text { volkomen stuitligging } \\
\text { onvolkomen stuitligging }\end{array}$ & 92 & 2,4 & 4 & 1,5 & 71 & 1,8 \\
overige stuitliggingen & 24 & 6,2 & 18 & 6,6 & 162 & 4,2 \\
overige liggingen & 18 & 0,6 & 0 & 0,0 & 13 & 0,3 \\
\end{tabular}

De verschillen in bovenstaande tabel zijn gering en niet significant. In groep $D$, de groep van patiënten met dubieus gebroken vliezen, kwamen niet meer liggingsafwijkingen voor dan in groep $\mathrm{K}$, de groep met patiënten met kortdurend gebroken vliezen, of groep L, de groep patiënten met langdurig gebroken vliezen.

\subsubsection{Kunstverlossingen}

De frequentie van kunstverlossingen in de drie onderzoeksgroepen is vermeld in tabel 38.

Tabel 38: Overzicht van het aantal kunstverlossingen in de drie onderzoeksgroepen (K, $D$ en $L)$.

\begin{tabular}{|c|c|c|c|c|c|c|}
\hline & $\begin{array}{l}\text { groep K } \\
n=3799\end{array}$ & $\%$ & $\begin{array}{r}\text { groep D } \\
n=273\end{array}$ & $\%$ & $\begin{array}{l}\text { groep L } \\
\mathrm{n}=3870\end{array}$ & $\%$ \\
\hline \multicolumn{7}{|l|}{ aard kunstverlossing } \\
\hline vacuümextractie & 320 & 8,4 & 11 & 4,0 & 399 & 10,3 \\
\hline forcipale extractie & 181 & 4,8 & 22 & 8.1 & 168 & 4,3 \\
\hline versie en extractie & 1 & 0,0 & 1 & 0,4 & 6 & 0.2 \\
\hline problemen schouders & 48 & 1,3 & 1 & 0,4 & 29 & 0,7 \\
\hline problemen nakomend hoofd & 7 & 0,2 & 1 & 0,4 & 10 & 0,3 \\
\hline primaire stuitextractie & 15 & 0,4 & 3 & 1,1 & 8 & 0.2 \\
\hline secundaire sectio & 223 & 5.9 & 20 & 7,3 & 373 & 9.6 \\
\hline ovetige & 11 & 0.3 & 0 & 0,0 & 15 & 0,4 \\
\hline onbekend & 173 & 4.6 & 0 & 0,0 & 92 & 2,4 \\
\hline totaal & 979 & 25.8 & 59 & 21,6 & 1100 & 28,4 \\
\hline
\end{tabular}

Het totaal aantal kunstverlossingen dat in groep D werd uitgevoerd is niet significant 
nadelen van twijfel

Uit tabel 38 blijkt ook dat in groep D minder vaak ( $p<0,02$ en $p<0,003$ ten opzichte van kortdurend respectievelijk langdurig gebroken vliezen) vacuümextracties werden verricht. Daarentegen werd vaker een forcipale extractie uitgevoerd in groep $D(p<0,03$ en $\mathrm{p}<0,008)$. Mogelijke verklaringen voor dit verschil zijn:

- Zuidlimburgse gynaecologen kiezen, bij een vaginale kunstverlossing, vaker voor de forceps dan hun lager wonende collegae.

- In groep D treedt vaker een verloskundige situatie op waarbij de geboorte van het kind snel en dus met behulp van een forceps moet worden gerealiseerd.

Omdat een geografisch verschil in geaardheid van gynaecologen meer aannemelijk is dan een geografisch verschil in het vórkomen van foetale nood komt de eerste verklaring meer in aanmerking dan de tweede.

Ook versie en extractie komt in groep $D$, de groep van patiënten met dubieus gebroken vliezen, vaker voor dan in de kortdurend gebroken vliezen groep $(p<0,02)$. Het gaat hier echter om zeer kleine aantallen en de relevantie van het verschil is dubieus.

\subsubsection{Dysmaturiteit}

Zoals in paragraaf 4.3 .11 reeds is vermeld heeft het geboortegewicht een beperkte waarde bij het bepalen van het dysmatuur of macrosoom zijn. Daarom zijn alleen de percentielen bewerkt (tabel 39).

Tabel 39: Verdeling in geboortegewichipercentielen in de drie onderzoeksgroepen (K, $D$ en $L$ ).

\begin{tabular}{|c|c|c|c|c|c|c|}
\hline & $\begin{array}{l}\text { groep K } \\
\mathbf{n}=3799\end{array}$ & $\%$ & $\begin{array}{r}\text { groep D } \\
n=273\end{array}$ & $\%$ & $\begin{array}{l}\text { groep L } \\
n=3870\end{array}$ & $\%$ \\
\hline \multicolumn{7}{|l|}{ percentiel } \\
\hline$>0$ en $<2,3$ & 81 & 2,1 & 11 & 4,0 & 57 & 1.5 \\
\hline 22,3 en $<5$ & 118 & 3,1 & 9 & 3,3 & 66 & 1.7 \\
\hline$\geq S$ en $<10$ & 190 & 5,0 & 17 & 6.2 & 160 & 4,1 \\
\hline 210 en $<25$ & 532 & 14.0 & 45 & 16.5 & 521 & 13,5 \\
\hline 225 en $<50$ & 881 & 23.2 & 65 & 23.8 & 957 & 24,7 \\
\hline 250 en $<75$ & 903 & 23.8 & 58 & 21,2 & 954 & 24,7 \\
\hline 275 en $<90$ & 572 & 15,1 & 32 & 11,7 & 623 & 16.1 \\
\hline 290 en $<95$ & 201 & 5,3 & 12 & 4,4 & 220 & 5.7 \\
\hline 295 en $<97.7$ & 158 & 4.2 & 5 & 1,8 & 130 & 3.4 \\
\hline$>97,7$ & 116 & 3,1 & 9 & 3.3 & 128 & 3,3 \\
\hline onbekend & 47 & 1,2 & 10 & 3.7 & 54 & 1.4 \\
\hline
\end{tabular}


hoofdstuk 5

Het aantal "onbekenden" in de groep met dubieus gebroken vliezen (groep D) is groter en significant verschillend ten opzichte van de groepen $K$ en $L(p<0,005)$. De verklaring voor het vaker onbekend zijn van de percentielen in deze groep is dat bij een aantal zwangerschappen de amenorroeduur minder dan 25 weken bedroeg en voor deze termijn zijn geen geboortepercentielen bekend.

De verklaring voor het significant zijn van het verschil tussen groep $K$ en groep $L$ in de immature periode wat betreft de percentielen is dat men in de immature periode mogelijk eerder zal twijfelen aan het gebroken zijn van de vliezen. Immers in de immature periode breken de vliezen zelden en zal men bij tekenen die op het gebroken zijn van de vliezen wijzen toch eerder geneigd zijn de diagnose in twijfel te trekken. Het aantal kinderen in groep D waarvan het geboortegewicht onder de $2,3^{\circ}$ percentiel (in dit onderzoek gedefinieerd als dysmaturitas) ligt is significant hoger dan in de langdurig gebroken vliezen groep ( $p<0,001)$. Een verklaring hiervoor zou kunnen zijn dat bij een oligohydramnion, een situatie die bij dysmaturitas vaak wordt aangetroffen, wordt getwijfeld aan het gebroken zijn van de vliezen.

\subsubsection{Neonatale morbiditeit}

Een van de weinige voor alle drie de groepen beschikbare parameters voor neonatale morbiditeit is de Apgarscore na 5 minuten (tabel 40).

Tabel 40: De Apgarscore in de drie onderzoeksgroepen.

\begin{tabular}{|c|c|c|c|c|c|c|}
\hline & $\begin{array}{r}\text { groep K } \\
\mathrm{n}=3799\end{array}$ & $\%$ & $\begin{array}{r}\text { groep D } \\
n=273\end{array}$ & $\%$ & $\begin{array}{c}\text { groep L } \\
n=3870\end{array}$ & $\%$ \\
\hline \multicolumn{7}{|l|}{ Apgarscore } \\
\hline$\geq 0$ en $\leq 4$ & 103 & 2,7 & 11 & 4,0 & 113 & 2.9 \\
\hline$>4$ en $\leq 6$ & 39 & 1.0 & 1 & 0,4 & 67 & 1.7 \\
\hline$>6$ en $\leq 8$ & 229 & 6.0 & 17 & 6.2 & 350 & 9.0 \\
\hline$>8$ en 10 & 3401 & 89.5 & 244 & 89,4 & 3319 & 85,8 \\
\hline onbekend & 27 & 0.7 & 0 & 0,0 & 21 & 0,5 \\
\hline
\end{tabular}

De verschillen in Apgarscore zijn gering en niet significant.

Een andere parameter voor de perinatale morbiditeit is het aantal kinderen dat moest worden opgenomen op de afdeling neonatologie. De gegevens hieromtrent zijn weergegeven in tabel 41 . 
Tabel 41: Opnamen op de afdeling neonatologie.

\begin{tabular}{rrrrrr}
$\begin{array}{r}\text { groep K } \\
\mathrm{n}=3799\end{array}$ & $\%$ & $\begin{array}{r}\text { groep D } \\
\mathrm{n}=273\end{array}$ & $\%$ & $\begin{array}{c}\text { groep L } \\
\mathrm{n}=3870\end{array}$ & $\%$ \\
\hline 750 & 19,7 & 122 & 44,7 & 1340 & 34,6
\end{tabular}

Het aantal kinderen in groep $D$ dat werd opgenomen op de afdeling neonatologie is significant hoger dan in groep $K$ of groep $L(p<0,0001$ en $p<0,03)$.

Dit verschil kan worden verklaard door een "voorzichtig" beleid. Daar niet met zekerheid bekend is of de vliezen langdurig of kortdurend gebroken zijn geweest wordt het kind ter observatie opgenomen op de afdeling neonatologie (31 van de 122 kinderen).

Geconcludeerd kan worden dat het aantal kinderen met een sub-optimale Apgarscore in groep D, de combinatiegroep van patiënten met dubieus gebroken vliezen, niet verhoogd is ten opzichte van de groepen met kortdurend respectievelijk langdurig gebroken vliezen maar in groep D worden wel significant meer kinderen opgenomen op de afdeling neonatologie ten opzichte van groep $\mathrm{K}$ en $\mathrm{L}$.

\subsubsection{Perinatale mortaliteit}

De perinatale mortaliteit is vermeld in tabel 42 .

Tabel 42: De perinatale mortaliteit in de drie onderzoeksgroepen.

\begin{tabular}{|c|c|c|c|c|c|c|}
\hline & $\begin{array}{l}\text { groep K } \\
n=3799\end{array}$ & $\%$ & $\begin{array}{r}\text { groep D } \\
n=273\end{array}$ & $\%$ & $\begin{array}{l}\text { groep L } \\
n=3870\end{array}$ & $\%$ \\
\hline \multicolumn{7}{|l|}{ groep } \\
\hline $\begin{array}{r}\text { ante partum overleden } \\
<28 \text { weken }\end{array}$ & 44 & 1.2 & 8 & 2,9 & 42 & 1,1 \\
\hline $\begin{array}{r}\text { ante partum overleden } \\
\qquad 28 \text { weken }\end{array}$ & 32 & 0.8 & 2 & 0,7 & 13 & 0,3 \\
\hline durante partu overleden & 11 & 0,3 & 0 & 0.0 & 13 & 0.3 \\
\hline binnen 24 uur overleden & 12 & 0,3 & 1 & 0,4 & 35 & 0,9 \\
\hline overleden $\boldsymbol{Z}$ tot $\boldsymbol{T}$ dag p.p. & 8 & 0,2 & 0 & 0,0 & 14 & 0,4 \\
\hline onbekend & 9 & 0.2 & 0 & 0.0 & 8 & 0,2 \\
\hline lotaal & 116 & 3.1 & 11 & 4.0 & 125 & 3.2 \\
\hline
\end{tabular}


hoofdstuk 5

In groep $D$ overleden meer kinderen ante partum voor de $28^{\mathrm{e}}$ week dan in de groepen $K$ en $L(p<0,02$ en $p<0,009)$. De verklaring hiervoor zou kunnen zijn dat in de groep van 16 tot 28 weken bij het constateren van een dan nog onverklaarde intrauteriene vruchtdood eerder wordt getwijfeld aan het gebroken zijn van de vliezen.

\subsubsection{Morbiditeit van de moeder}

In tabel 43 is het al dan niet afwijkende verloop van het kraambed in de verschillende groepen weergeven.

Tabel 43: Het verloop van het kraambed in de drie onderzoeksgroepen $K, D$, en $L$.

\begin{tabular}{rrrrrrr}
\hline & $\begin{array}{r}\text { groep K } \\
\mathrm{n}=3799\end{array}$ & $\%$ & $\begin{array}{r}\text { groep D } \\
\mathrm{n}=273\end{array}$ & $\%$ & $\begin{array}{c}\text { groep L } \\
\mathrm{n}=3870\end{array}$ & $\%$ \\
\cline { 2 - 6 } verloop & & & & & & \\
geen afwijkingen & 2847 & 74,9 & 183 & 67,0 & 2863 & 74,0 \\
afwijkend verloop & 289 & 7,6 & 38 & 13,9 & 339 & 8,8 \\
onbekend & 663 & 17,5 & 52 & 19,0 & 668 & 17,3 \\
\hline
\end{tabular}

Als afwijkend werd aangemerkt een temperatuurverhoging boven de 38 graden Celsius gedurende tenminste één dag (21 patiënten), of toediening van antibiotica en ermetrine (17 patiënten) wegens riekende lochia zonder temperatuurverhoging.

Het aantal malen dat het kraambed niet normaal verloopt is significant hoger in groep $D$, de groep van patiënten met dubieus gebroken vliezen, ten opzichte van de groepen met kortdurend (groep $\mathrm{K}$ ) respectievelijk langdurig (groep L) gebroken vliezen $(p<0,001$ en $p<0,02)$.

De groep "onbekend" bestaat voor een groot deel uit patiënten die poliklinisch bevielen en dus enige uren na de baring de kliniek verlieten.

Als uiting van maternale morbiditeit kan ook het aantal klinische verpleegdagen na de baring worden gezien. Dit is vermeld in tabel 44 . 
Tabel 44: De duur van het klinisch kraambed in de drie onderzoeksgroepen.

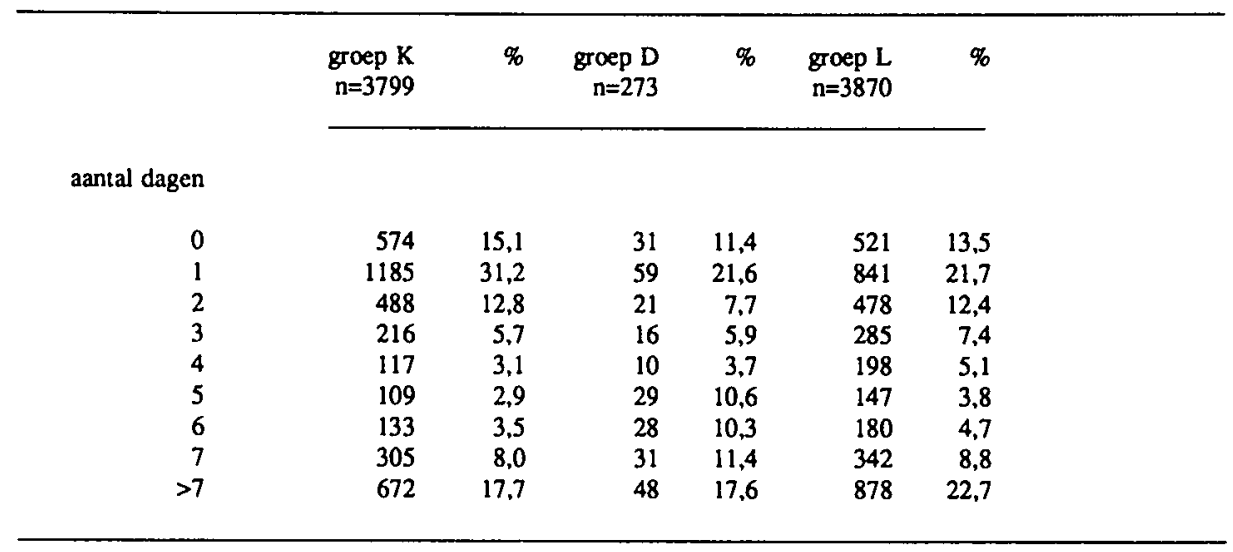

In groep $D$ verblijven opvallend veel patiënten 5 tot 7 dagen in het ziekenhuis en de verschillen met groep $K$ en $L$ zijn significant ( $p<0,001$ respectievelijk $p<0,004)$. De overige verschillen zijn niet significant.

Geconcludeerd kan worden dat in groep D, de groep van patiënten met dubieus gebroken vliezen, het kraambed vaker afwijkend verloopt vergeleken met de groep met kortdurend respectievelijk de groep met langdurig gebroken vliezen ( $<<0,0001$ en $p<0,02)$. In groep $D$ komt een klinisch kraambed van 5 of 6 dagen significant vaker voor dan in de twee andere groepen.

Samenvattend kan worden geconcludeerd dat het twijfelen aan het gebroken zijn van de vliezen vaker samengaat met nadelige consequenties voor moeder en kind. De complicaties die werden geregistreerd in de groep patiënten met dubieus gebroken vliezen zijn meer vergelijkbaar met de groep met langdurig gebroken vliezen dan met de groep met kortdurend gebroken vliezen. Zelfs bleek de groep met dubieus gebroken vliezen in sommige opzichten ongunstiger uitkomsten te hebben dan de groep met langdurig gebroken vliezen. Bij twijfel aan het gebroken zijn van de vliezen dient een zwangere patiënte dan ook te worden behandeld als een "high risk"-patiënte.

\section{Conclusies}

1. In de groep patiënten met dubieus gebroken vliezen bevielen meer patiënten in het immature tijdperk ten opzichte van de groep met kortdurend gebroken vliezen. In de groep met dubieus gebroken vliezen bevielen meer patiënten in het prema- 
hoofdstuk 5

ture tijdperk ten opzichte van zowel de groep met kortdurend als de groep met langdurig gebroken vliezen.

2. In de groep met dubieus gebroken vliezen komen evenveel liggingsafwijkingen voor als in de groep met kortdurend of langdurig gebroken vliezen.

3. In de groep patiënten waarbij aan het gebroken zijn van de vliezen wordt getwijfeld wordt niet vaker een kunstverlossing uitgevoerd dan in de groep met kortdurend of langdurig gebroken vliezen.

4. In de groep patiënten waar wordt getwijfeld aan het gebroken zijn van de vliezen wordt vaker een dysmatuur $\left(<p_{2,3}\right)$ kind geboren dan in de groep met langdurig gebroken vliezen.

5. De kinderen die zijn geboren in de groep met langdurig gebroken vliezen worden na de geboorte vaker opgenomen op de afdeling neonatologie dan de kinderen die geboren zijn na kortdurend gebroken vliezen.

6. Bij een intrauteriene vruchtdood vóór de $28^{e}$ week van de zwangerschap is het voorstelbaar dat vaak aan het staan van de vliezen wordt getwijfeld.

7. Bij twijfel aan het gebroken zijn van de vliezen verloopt het kraambed van de moeder vaker afwijkend en verblijft de moeder vaker 5 tot 7 dagen in het ziekenhuis in vergelijking met patiënten met kortdurend respectievelijk langdurig gebroken vliezen.

\section{Discussie}

Groep D bestaat uit patiënten met dubieus gebroken vliezen in drie Zuidlimburgse klinieken in de periode van 01-01-1985 tot 01-07-1986. De groepen K en L bestaan uit patiënten met kortdurend en langdurig gebroken vliezen uit de periode 01-01-1985 tot 01-01-1986, verzameld door de S.I.G.. Groep D is eigenlijk een subgroep van het S.I.G.-bestand, daar alle drie de klinieken aan de S.I.G. rapporteerden in 1985.

De leeftijd van de patiënten uit groep D evenals het aantal graviditeiten dat zij doormaakten is vergelijkbaar met groep $\mathrm{K}$ en $\mathrm{L}$ en deze twee kenmerken kunnen eventuele verschillen niet verklaren. Van de eigen onderzoeksgroep zijn veel meer gegevens bekend dan waarvan in dit hoofdstuk gebruik werd gemaakt. De door de S.I.G. verzamelde gegevens vormen de beperkende factor: alleen die gegevens die ook door de S.I.G. op betrouwbare wijze konden worden verzameld, werden vergeleken. 


\section{Hoofdstuk 6}

\section{Resultaten van bepalingsmethoden bij drie groepen patiënten: waarbij de vliezen zeker gebroken, zeker niet gebroken en niet zeker waren gebroken}

\subsection{Inleiding}

De bepalingen werden eerst verricht bij patiënten met een bekende en zekere diagnose (staande of gebroken vliezen) ter vaststelling van de referentiewaarden. Nadat deze bepalingen waren uitgevoerd werden deze ook uitgevoerd in vaginaal afgelopen vocht van patiënten waarbij aan het gebroken zijn van de vliezen werd getwijfeld. Het doel van dit deel van het onderzoek was het vinden van een methode waarmee het mogelijk was bij dubieus gebroken vliezen tot een meer zekere en snellere diagnose te komen en aldus het twijfelen aan het gebroken zijn van de vliezen zo veel mogelijk te beperken.

In dit hoofdstuk wordt tevens de historie van de verschillende bepalingen besproken.

\subsection{Opzet van het onderzoek}

\subsubsection{De groep met zeker staande of gebroken vliezen}

In de periode van 01-01-1985 tot 01-01-1986 werden in de klinieken zoals genoemd in paragraaf 3.2 monsters (vocht) verzameld van patiënten waarvan klinisch met zekerheid bekend was of de vliezen stonden of waren gebroken.

De insluitcriteria voor dit gedeelte van het onderzoek waren:

1. De diagnose, staande dan wel gebroken vliezen moet zeker zijn.

2. De amenorroeduur moet eveneens zeker zijn en langer of gelijk aan 16 weken en korter of gelijk aan 42 weken.

Aangenomen werd dat de vliezen bij een patiënte stonden indien:

- anamnestisch geen redenen aanwezig waren om aan te nemen dat de vliezen waren gebroken (bij patiënten die voor een normale zwangerschapscontrôle de polikliniek bezochten) 
hoofdstuk 6

of

- bij onderzoek in speculo staande vliezen werden gezien zonder waarneembaar vochtverlies.

Aangenomen werd dat de vliezen gebroken waren indien:

- de vliezen artificieel waren gebroken

of

- veel, niet bloederig vocht uit de cervix uteri komend, werd gezien.

Bij 26 patiënten werd vruchtwater verkregen door middel van een amnionpunctie. In alle monsters werd een aantal bepalingen uitgevoerd ter vaststelling van de "normaalwaarden" c.q. referentiewaarden. Het gebruikte registratieformulier is bijgevoegd als bijlage 7 .

De zwangerschapsduur werd als zeker beschouwd als een vroege echoscopie (tussen de $8^{\circ}$ en $12^{c}$ week verricht) een zwangerschapsduur opleverde die in overeenstemming (minder dan een week verschil) was met de amenorroeduur. Als de zwangerschapsduur niet conform de echoscopisch bepaalde zwangerschapsduur was, werd de echoscopisch bepaalde "zwangerschapsduur" als zeker beschouwd indien tenminste twee echoscopische metingen met elkaar in overeenstemming waren. De zwangerschapsduur werd vervolgens bepaald volgens de uitslag van deze twee echoscopieën.

In de groep met een zekere diagnose werd gedurende de zwangerschap een aantal soorten vocht, anders dan vruchtwater, verzameld die vaginaal kunnen aflopen en daardoor gedurende de zwangerschap twijfel kunnen veroorzaken of de vliezen staan dan wel gebroken zijn. Deze soorten vocht zijn:

1. urine

2. bloed

3. cervixslijm

4. fluor vaginalis

5. semen.

Bij elke patiënte werd zoveel mogelijk van de boven genoemde soorten vocht verzameld. De bepaling van de referentiewaarden van semen werd uitgevoerd in het semen van 5 fertiele mannen.

Het verzamelen van het vocht verliep als volgt:

- Vruchtwater werd opgezogen uit de fornix posterior, waarbij een speculum werd gebruikt.

- Urine werd via catheterisatie verkregen indien de vliezen waren gebroken. Indien de vliezen stonden werd midstream urine opgevangen. 
diagnostiek

- Bloed werd verkregen via een venapunctie.

- Cervixslijm werd opgezogen tijdens het onderzoek in speculo. Ter vermijding van mogelijke complicaties werd alleen het buiten de endocervix gelegen slijm verzameld, in het algemeen na de $36^{\circ}$ week van de zwangerschap.

- Fluor vaginalis werd eveneens opgezogen tijdens het onderzoek in speculo. De diagnose staande vliezen moest hier, evenals bij het verzamelen van het cervixslijm, zeker zijn.

De analyse van deze soorten vocht was gericht op de beantwoording van het derde deel van de vraagstelling: hoe kan twijfel aan de diagnose gebroken vliezen worden voorkomen. Gekozen is voor objectieve methoden, die niet invasief zijn en die volgens de literatuur een sensitiviteit en specificiteit hebben van meer dan $70 \%$.

Door bovenstaande selectie resteren de volgende bepalingsmethoden (tabel 45 ).

Tabel 45: De bepalingen die zijn uitgevoerd om de diagnose gebroken vliezen te stellen of uit te sluiten.

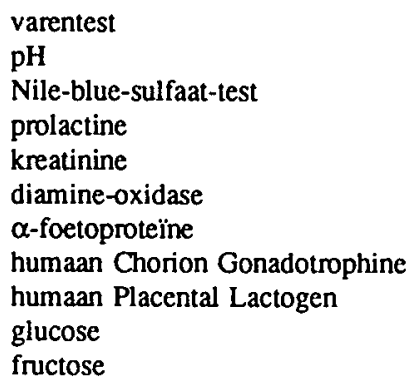

De pH-bepaling, varentest en de Nile-blue-sulfaat-test werden direct uitgevoerd. Het resterende deel van het vocht werd bewaard bij een temperatuur van -30 graden Celsius om later de overige bepalingen uit te kunnen voeren. De resultaten worden in dit hoofdstuk beschreven.

Samenstelling van de groep met een zekere diagnose

In totaal werd bij 203 patiënten met een zekere diagnose vocht verzameld. Bij 123 patiënten met zeker gebroken vliezen werd vruchtwater verkregen en bij 24 patiënten met aanvankelijk staande vliezen werd zowel vruchtwater als fluor vaginalis verzameld. Bij 80 patiënten met zeker staande vliezen werd fluor vaginalis afgenomen; bij 18 van hen tevens cervixslijm. Van de gehele groep met een zekere diagnose werd 201 maal serum verkregen en 198 urinemonsters. 
hoofdstuk 6

De verdeling van de patiënten over de amenorroeduurklassen is gegeven in tabel 46 .

Tabel 46: De verdeling naar amenorroeduurklassen bij patiënten met een zekere diagnose, waarbij vocht werd afgenomen.

\begin{tabular}{|c|c|c|c|c|c|}
\hline & $\begin{array}{r}\text { aantal } \\
\text { vruchtwater }\end{array}$ & $\begin{array}{l}\text { aantal } \\
\text { serum }\end{array}$ & $\begin{array}{r}\text { aantal } \\
\text { urine }\end{array}$ & $\begin{array}{r}\text { aantal } \\
\text { fluor }\end{array}$ & $\begin{array}{c}\text { aantal } \\
\text { cervixslijm }\end{array}$ \\
\hline \multicolumn{6}{|l|}{$\begin{array}{r}\text { amenorroe } \\
\text { (weken) }\end{array}$} \\
\hline$\geq 16$ en $<20$ & 12 & 19 & 18 & 11 & 1 \\
\hline$>20$ en $<24$ & 10 & 19 & 19 & 9 & 0 \\
\hline$\geq 24$ en $<28$ & 14 & 20 & 20 & 7 & 0 \\
\hline$\geq 28$ en $<32$ & 12 & 26 & 26 & 15 & 1 \\
\hline$\geq 32$ en $<36$ & 25 & 32 & 33 & 12 & 2 \\
\hline$\geq 36$ en $\leq 42$ & 74 & 85 & 82 & 26 & 14 \\
\hline Totaal & 147 & 201 & 198 & 80 & 18 \\
\hline
\end{tabular}

Bij alle patiënten werden de direct uit te voeren bepalingen verricht (varentest, pH-bepaling en Nile-blue-test). De later uit te voeren bepalingen konden niet bij allen worden verricht: een klein aantal monsters ging ten gevolge van het invriezen verloren. Met name bleken de hardplastic spuiten, waarin fluor vaginalis werd bewaard, niet bestand tegen het invriezen. De juiste aantallen patiënten per bepaling zijn steeds in de betreffende paragrafen vermeld.

\subsubsection{De groep met een onzekere diagnose}

Bij patiënten met dubieus gebroken vliezen werd alleen het onbekende vocht afgenomen. Dit gebeurde in de periode van 01-01-1986 tot 01-06-1986 in de drie eerder genoemde klinieken (paragraaf 3.2).

Samenstelling van de groep met dubieus gebroken vliezen

De bepalingen (tabel 45) in de groep met dubieus gebroken vliezen werden uitgevoerd bij 120 patiënten. Bij deze patiënten waarbij het niet duidelijk was of de vliezen stonden dan wel waren gebroken werd vaginaal afgelopen vocht opgevangen. Het registratieformulier is bijgevoegd als bijlage 7 .

De diagnose staande dan wel gebroken vliezen kon in deze groep met zekerheid retrospectief worden gesteld door bestudering van de beschikbare patiëntengegevens. 
Dat wil zeggen dat op grond van klinische parameters, na afloop van de baring, kon worden vastgesteld of op het moment van het dubieuze vruchtwaterverlies de vliezen stonden of waren gebroken. De gegevens van patiënten waarbij deze "gouden standaard" niet kon worden toegepast, werden bij de uiteindelijke verwerking van de resultaten van de bepalingsmethoden niet meegenomen.

De diagnose gebroken vliezen werd gesteld indien:

- Patiënte na de eerste symptomen van gebroken vliezen, min of meer continu onwillekeurig vochtverlies hield,

én

bij het eerste vaginale toucher, na het optreden van de eerste symptomen, geen vliezen werden gevoeld.

De diagnose staande vliezen werd gesteld indien:

- de zwangerschap, na de eerste klacht van patiënte, minstens 4 weken ongecomplién ceerd verliep, zonder dat onwillekeurig vochtverlies optrad,

bij het eerste vaginale toucher na het optreden van de klacht vliezen werden gevoeld.

Van 4 van de 120 patiënten waren onvoldoende gegevens beschikbaar, van 16 anderen waren de gegevens onvoldoende eenduidig om met zekerheid te kunnen beslissen of de vliezen hadden gestaan of waren gebroken. Er bleven dus 100 patiënten over waarbij op het moment van de klacht onzekerheid bestond over het staan van de vliezen, maar waarbij achteraf kon worden bepaald dat de vliezen hadden gestaan (61 patiënten) of waren gebroken (39 patiënten). Het retrospectieve onderzoek, waarbij op grond van de eerder omschreven parameters werd bepaald of de vliezen waren gebroken of hadden gestaan, vond plaats nadat de periode van het verzamelen van de monsters was verstreken en de bepalingen in deze monsters waren uitgevoerd. Dit om beinvloeding van de onderzoeksresultaten te voorkomen. Ook werd een vermoedelijke diagnose niet medegedeeld aan de behandelaar om beïnvloeding van het obstetrische beleid te voorkomen.

De verdeling van de amenorroeduur in de groep met dubieus gebroken vliezen die volgens de hierboven beschreven criteria geschikt was voor verder onderzoek, is gegeven in figuur 4. 
hoofdstuk 6

Figuur 4: De verdeling van de amenorroeduur in de groep met dubieus gebroken vliezen ( $n=100)$.

\section{Frequentie van voorkomen \\ dubieus gebroken vliezen}

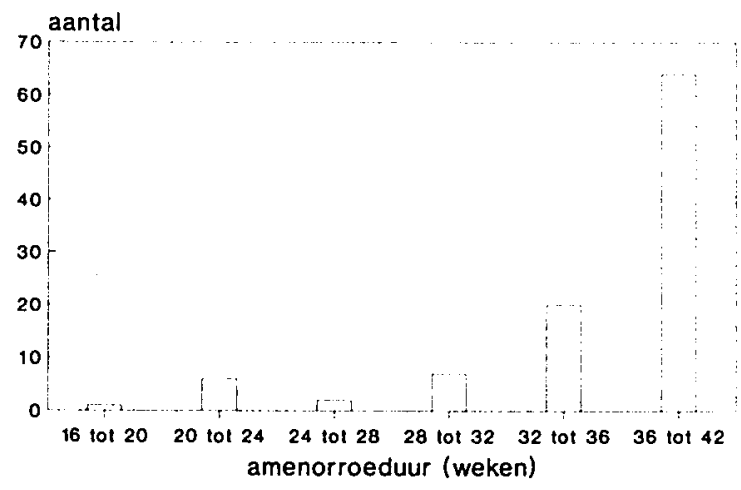

Uit figuur 4 blijkt dat het twijfelen aan het staan van de vliezen zelden voorkomt in de immature periode $(11 \%)$, relatief frequent in de premature periode $(25 \%)$ en het meest frequent $(64 \%)$ in de mature periode.

Met behulp van de reeds verkregen waarden van de bepalingen uitgevoerd bij patiënten met een zekere diagnose werd de diagnostische betrouwbaarheid van de verschillende bepalingsmethoden onderzocht. 


\section{- Resultaten van het onderzoek}

\subsubsection{Eiwitbepaling}

Bepalingen in vruchtwater, serum, urine en semen konden zonder voorbewerking worden uitgevoerd. Dit bleek niet mogelijk te zijn voor fluor vaginalis en cervixslijm, evenmin bij een aantal monsters verkregen bij patiënten met dubieus gebroken vliezen. Deze secreten waren zo viskeus dat bepalingen eerst mogelijk bleken na voorbewerking. Het beschikbare slijm werd daartoe gewogen en met een bekende hoeveelheid fysiologische zoutoplossing overgoten. Hierna werd gedurende 5 minuten intensief gemengd met een vortexmixer. Vervolgens werd het mengsel twee minuten ultrasoon getrild en nogmaals twee minuten behandeld met de vortexmixer. $\mathrm{Na} 10$ minuten te hebben gecentrifugeerd bij $5.000 \mathrm{~g}$. werd in de heldere bovenstaande vloeistof de analyse uitgevoerd. Uit proeven waarbij de behandeltijd werd gevarieerd bleek dat deze tijd optimaal was. Langere behandeltijd van het vocht resulteerde niet in hogere concentraties.

De bepaling van de totale hoeveelheid eiwit per verkregen vocht is uitgevoerd met behulp van de biureet-methode (Roche Diagnostica).

Omdat de eiwitbepaling als laatste werd uitgevoerd bleek niet steeds voldoende vocht over te zijn om een eiwitbepaling te kunnen uitvoeren. Het totale aantal eiwitbepalingen en de gemiddelde eiwitconcentratie bij patiënten met een zekere diagnose met de bijbehorende standaarddeviatie en dit voor vruchtwater, serum, fluor en cervixslijm is weergegeven in tabel 47.

Tabel 47: De gemiddelde concentratie van eiwit (gem. eiwil conc.) \pm de standaard-deviatie (S.D.) in klassen van amenorroeduur in vruchtwater (vrw.), serum. fluor vaginalis (fluor) en cervixslijm en het aantal eiwitbepalingen (aantal) dat is uitgevoerd per vocht bij patiënten met een zekere diagnose.

\begin{tabular}{|c|c|c|c|c|}
\hline & $\begin{array}{r}\text { gem eiwit } \\
\text { conc. vrw. } \\
\pm \text { S.D. } \\
(g / 1)\end{array}$ & $\begin{array}{r}\text { gem. eiwit } \\
\text { conc. serum } \\
\pm S . D . \\
(\mathrm{g} / \mathrm{l})\end{array}$ & $\begin{array}{r}\text { gem eiwit } \\
\text { conc. fluor } \\
\pm \text { S.D. } \\
(\mathrm{g} / \mathrm{l})\end{array}$ & $\begin{array}{r}\text { gem eiwit } \\
\text { conc. cervix- } \\
\text { slijm } \pm \text { S.D. } \\
(\mathrm{g} / \mathrm{A})\end{array}$ \\
\hline \multicolumn{5}{|l|}{$\begin{array}{r}\text { amenorroe } \\
\text { (weken) }\end{array}$} \\
\hline 16 tot 20 & $7,3 \pm 4,9$ & $63,7 \pm 6,7$ & $1,1 \pm 0,9$ & 0,6 \\
\hline 20 tot 24 & $9.1 \pm 6.8$ & $65.5 \pm 6.6$ & $1,0 \pm 1,0$ & - \\
\hline 24 tot 28 & $7.2 \pm 3.7$ & $62,1 \pm 5,2$ & $0,7 \pm 0,4$ & - \\
\hline 28 tot 32 & $5,3 \pm 2,3$ & $59,8 \pm 5,7$ & $0.8 \pm 0.6$ & - \\
\hline 32 tot 36 & $4,0 \pm 2,1$ & $57,6 \pm 6,2$ & $0,8 \pm 0,9$ & 0,0 \\
\hline 36 tot 42 & $2,8 \pm 1,2$ & $58,6 \pm 7,0$ & $3,0 \pm 3,4$ & $5,2 \pm 2,4$ \\
\hline Aantal & 129 & 126 & 59 & is \\
\hline
\end{tabular}


hoofdstuk 6

De uitkomsten in urine zijn niet weergegeven in tabel 47 daar met de in dit onderzoek gebruikte bepalingsmethode géén ( 152 van de 167 monsters) of slechts zeer weinig (15 van de 167 monsters) eiwit kon worden aangetoond.

In semen komen concentraties eiwit voor die vergelijkbaar zijn met serum: in 5 semenmonsters van fertiele mannen gemiddeld $53,6 \mathrm{~g} / \mathrm{l}$.

De concentraties van de verschillende stoffen die werden gebruikt om de diagnose staande of gebroken vliezen te stellen werden vervolgens gedeeld door de concentratie $(\mathrm{g} / \mathrm{l})$ totaal eiwit. Het voordeel van deze methode is dat geen rekening moet worden gehouden met het verdunnen van het slijm dat nodig is om de bepalingen te kunnen uitvoeren. Deze methode heeft verder als voordeel dat eventueel aanwezig bloed in vaginaal afgelopen lichaamsvloeistoffen, door de relatief hoge eiwitconcentratie in serum, geen invloed meer heeft op de betrouwbaarheid van de verschillende bepalingen (paragraaf 6.7.5). 


\section{- Resultaten van het onderzoek}

\subsection{Varentest}

\subsubsection{Inleiding}

De varentest is sinds 1945 bekend (paragraaf 2.5.2) en is in combinatie met het onderzoek in speculo en de pH-bepaling een vaak gebruikte test om de diagnose gebroken vliezen te stellen (Garite e.a. 1981, Stedman e.a. 1981, Berkowitz e.a. 1982, Perkins 1982). Ook bij onderzoek naar de effectiviteit van antibiotica en weeënremmers wordt de varentest gebruikt om de diagnose gebroken vliezen zeker te stellen. Niet alleen in de literatuur wordt een belangrijke betekenis toegekend aan de varentest: in de enquêtegroep van dit onderzoek (paragraaf 3.3.4) bleek bij 97,4\% een positieve varentest van beslissende betekenis te zijn geweest voor klinische zorg.

Tabel 48 geeft een literatuuroverzicht van de betrouwbaarheid van de varentest (de sensitiviteit en specificiteit is, met behulp van de resultaten door de auteurs gegeven, berekend).

Tabel 48: Overzicht van de betrouwbaarheid van de varentest bij het stellen van de diagnose gebroken vliezen.

\begin{tabular}{rrrrr} 
jauteur & aantal & $\begin{array}{r}\text { sensitivi- } \\
\text { teit (\%) }\end{array}$ & $\begin{array}{r}\text { specifici- } \\
\text { teit (\%) }\end{array}$ \\
\cline { 2 - 5 } & & & & \\
Kardos en Tamasi & 1955 & 160 & 96,8 & - \\
Neuhaus & 1956 & 500 & 100,0 & 100.0 \\
Paavola & 1958 & 264 & 99.2 & 97.4 \\
Langreder & 1958 & 150 & 73,3 & 88,0 \\
Ruck & 1959 & 273 & 97.1 & 77.2 \\
Volet en Morier & 1960 & 301 & 89.6 & 94,5 \\
Smith en Callagan & 1962 & 509 & 98.7 & 98.1 \\
Kovacs & 1962 & 224 & 96,3 & 96,9 \\
Ferron en Bilodeau & 1963 & 192 & 95.0 & 96.4 \\
Tricomi e.a. & 1966 & 233 & 95,8 & 95.6 \\
Lange Friedman en & & & & 94.2 \\
McElin & 1969 & 100 & 87,1 & \\
\hline
\end{tabular}

Blijkbaar is er alle reden om aan de varentest een grote betekenis toe te kennen: verschillende onderzoekers vinden een hoge tot zeer hoge sensitiviteit en specificiteit voor de varentest (tabel 48). Toch moet bij een aantal onderzoekers twijfel hebben bestaan over de betrouwbaarheid van de varentest. Dit is af te leiden uit het feit dat 
hoofdstuk 6

ook andere diagnostische tests, om de diagnose gebroken vliezen aan te tonen, werden gebruikt (Elmfors e.a. 1974, Gorodeski e.a. 1979, Koninckx e.a. 1981, Huber e.a. 1983, Rochelson e.a. 1983, 1987, Hjertberg e.a. 1987). In deze meer recente literatuur komt tot uiting dat de varentest als minder betrouwbaar moet worden beschouwd. Niet duidelijk is overigens waar deze conclusie, minder betrouwbaar, op gebaseerd is.

\subsubsection{Uitvoering van de varentest}

Zoals in paragraaf 6.1 en 6.2 is beschreven werd zowel bij patiënten bij wie de diagnose bekend was als bij een groep patiënten waar aan het staan van de vliezen werd getwijfeld vocht verzameld. In de groep met een zekere diagnose werd, ter bepaling van de referentiewaarden, vruchtwater, bloed, urine, fluor vaginalis en cervixslijm afgenomen. In de groep met dubieus gebroken vliezen werd éénmalig vaginaal afgelopen vocht verzameld.

Van alle monsters werd direct na het verzamelen een varentest gedaan op de volgende wijze:

op een objectglaasje, met een codenummer, werd in een cirkel met een straal van 0,5 $\mathrm{cm}, 20$ microliter vocht aangebracht. Het objectglaasje werd op een warmhoudplaatje met een temperatuur van 37 graden Celsius gelegd en zo aan de lucht gedroogd.

Nadat de preparaten waren gemaakt, werden de glaasjes bekeken door een microscoop met een vergroting van 100 maal. Bij het zien van een of meerdere varens (figuur 2) werd het preparaat als positief beoordeeld. Als in het hele preparaat geen enkele varen te zien was werd het als negatief afgegeven. Het aantal varens en de grootte van het gebied met varens was niet van belang daar van kwantificering van de varentest is afgezien. Het niet kunnen kwantificeren van de varentest is immers aangetoond (Roland 1971).

In een latere fase werd de code verbroken.

\subsubsection{Eigen resultaten}

Pilot study

Al eerder (1983) werd een pilot study verricht. Van 93 patiënten met staande vliezen, die voor een zwangerschapscontrole de polikliniek bezochten, werd van vocht, verkregen uit de baarmoedermond, een varentest gedaan zoals beschreven in paragraaf 6.4.2 en beoordeeld door een onderzoeker. Van 51 andere patiënten met zeker gebroken vliezen kon van vruchtwater een varentest worden verricht. Als controle werd van deze 51 patiënten catheter-urine afgenomen en ook hiervan werd een varentest uitgevoerd. De resultaten zijn vermeld in tabel 49. 
Tabel 49: Resultaten varentest van de pilotstudy (1983): bij staande vliezen van vruchtwater en urine.

\begin{tabular}{|c|c|c|c|c|c|c|}
\hline & \multicolumn{2}{|c|}{$\begin{array}{r}\text { staande vliezen } \\
\text { cervixslijm }(n=93) \\
\text { varentest }\end{array}$} & \multicolumn{2}{|c|}{$\begin{array}{r}\text { gebroken vliezen } \\
\text { vruchtwater }(n=51) \\
\text { varentest }\end{array}$} & \multicolumn{2}{|c|}{$\begin{array}{r}\text { gebroken vliezen } \\
\text { urine }(n=51) \\
\text { varentest }\end{array}$} \\
\hline & + & - & + & - & + & - \\
\hline \multicolumn{7}{|l|}{$\begin{array}{r}\text { amenorroe } \\
\text { (weken) }\end{array}$} \\
\hline 16 tot 20 & 2 & 7 & 1 & 0 & 0 & 1 \\
\hline 20 tot 24 & 1 & 7 & 1 & 0 & 0 & 1 \\
\hline 24 tot 28 & 4 & 17 & 1 & 0 & 0 & 1 \\
\hline 28 tot 32 & 5 & 14 & 1 & 0 & 0 & 1 \\
\hline 32 tot 36 & 2 & 15 & 7 & 0 & 0 & 7 \\
\hline 36 tot 42 & 2 & 17 & 39 & 1 & 6 & 34 \\
\hline totaal & 16 & 77 & 50 & 1 & 6 & 45 \\
\hline
\end{tabular}

Uit de resultaten in tabel 49 kan de sensitiviteit worden berekend: $98 \%$. De specificiteit is: $82,8 \%$. Deze resultaten komen goed overeen met de resultaten zoals die in de literatuur zijn beschreven. Deze resultaten zijn echter verkregen bij patiënten met een zekere diagnose. De opzet van een dergelijk onderzoek geeft echter geen antwoord op de vraag: hoe betrouwbaar is de varentest indien wordt getwijfeld aan het staan van de vliezen? De varentest dient derhalve te worden getoetst als het onduidelijk is of vruchtwaterverlies bestaat of niet.

Uit tabel 49 blijkt bovendien dat urine een bron van fout-positieve resultaten kan zijn.

6.4.4 Resultaten van de varentest in de groep patiënten met een zekere diagnose

In het voorliggende onderzoek werd ook de varentest verricht bij patiënten met een zekere diagnose: zeker staande of zeker gebroken vliezen, in de eerder genoemde (paragraaf 6.2.1) soorten vocht.

De preparaten werden door één en dezelfde onderzoeker beoordeeld. Figuur 5 geeft het aantal varentests dat per amenorroegroep is gemaakt: in totaal 636. 
hoofdstuk 6

Figuur 5: Het aantal varentests dat verricht werd per klasse van amenorroe en per soort vocht.

Aantal uitgevoerde varentesten

patiënten met een zekere diagnose

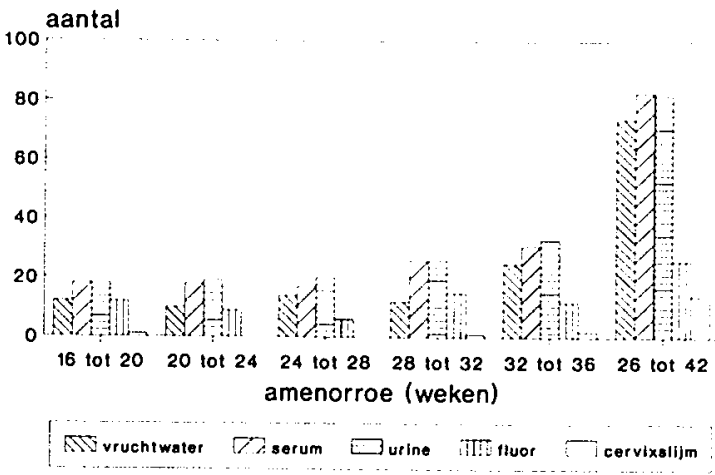

Indien de varentest een goede test voor de detectie van gebroken vliezen is zouden alleen de varentests van vruchtwater positief zijn, en van de niet-vruchtwatermonsters negatief. De resultaten van de varentest zijn samengevat in tabel 50.

Tabel 50: De resultaten van de varentests van vruchtwater, serum, urine. fluor vaginalis en cervixslijm.

\begin{tabular}{|c|c|c|c|}
\hline $\begin{array}{l}\text { vrucht- } \\
\text { water }\end{array}$ & serum & urine & $\begin{array}{r}\text { fluor } \\
\text { vaginalis }\end{array}$ \\
\hline
\end{tabular}

resultaat

$\begin{array}{lrrrrr}\text { positief } & 138 & 62 & 16 & 8 & 9 \\ \text { negatief } & 9 & 131 & 182 & 72 & 9 \\ \text { totaal } & 147 & 193 & 198 & 80 & 18\end{array}$

Uit tabel 50 blijkt dat 147 varentests van vruchtwater zijn gemaakt, maar 233 tests werden beoordeeld als positief. Geconcludeerd moet worden dat de varentest vaak fout-positief is. De helft van de preparaten van cervixslijm werd positief gescoord en $32 \%$ van de serumpreparaten.

De varentests van urine gaven in $8,1 \%$ een fout-positieve uitslag en $10 \%$ van de varentests van fluor vaginalis is positief. 
Bovendien werden in één van de 5 preparaten van semen varens aangetroffen.

Als wordt aangenomen dat het vocht afkomstig van patiënten met een zekere diagnose afkomstig is van twee groepen patiënten, de vruchtwatermonsters vertegenwoordigen de groep met gebroken vliezen en de rest van de monsters vertegenwoordigen de groep met staande vliezen, dan is het ook in dit onderdeel van het onderzoek mogelijk om de sensitiviteit en specificiteit van de varentest te berekenen. De sensitiviteit is dan $138 / 147=93,9 \%$ en de specificiteit $394 / 489=80,6 \%$. Ook deze resultaten zijn vergelijkbaar met de sensitiviteit en specificiteit van de varentest, als diagnosticum bij gebroken vliezen, zoals in de literatuur werden vermeld en in overeenstemming met de eerder genoemde pilot study.

\section{Conclusie}

In dit deel van het onderzoek bij patiënten met een zekere diagnose was de sensitiviteit van de varentest $93,9 \%$ en de specificiteit $80,6 \%$. Deze waarden komen overeen met die welke in de literatuur worden gevonden en met de eigen pilot study.

\subsubsection{Resultaten van de varentest in de groep patiënten met dubieus gebroken vliezen}

Een geheel andere groep patiënten is die met dubieus gebroken vliezen. De samenstelling van deze groep is beschreven in paragraaf 6.2. Met name in deze groep is de betrouwbaarheid van de varentest van belang.

De 120 preparaten werden beoordeeld door 30 "onderzoekers", verdeeld in drie categorieën: 10 gynaecologen, 10 arts-assistenten gynaecologie/obstetrie en 10 coassistenten. De "onderzoekers" werd verzocht op een formulier in te vullen of hij/zij varens zag (+), geen varens zag (-) of het niet wist (?). Vervolgens moest worden aangegeven of op grond van deze gegevens patiënte al dan niet moest worden opgenomen.

Nadat een "onderzoeker" 120 preparaten had beoordeeld, werden de preparaten at random in een andere volgorde gezet voor de volgende "onderzoeker". Zoals eerder vermeld bleven 100 patiënten over ter beoordeling van wie er 39 gebroken vliezen en 61 staande vliezen hadden ten tijde van de afname van het te onderzoeken vocht. Voor elke "onderzoeker" kan een sensitiviteit en specificiteit worden berekend (bijlage 8). Deze sensitiviteit en specificiteit verschillen aanzienlijk tussen de "onderzoekers". De sensitiviteit varieert van 18,0 tot $69,2 \%$ en de specificiteit van 44,3 tot $88,5 \%$.

Dit is belangrijk daar literatuur gegevens meestal tot stand komen door de resultaten weer te geven van één onderzoeker. 
hoofdstuk 6

In tabel 51 zijn de gemiddelde sensitiviteit en specificiteit van de verschillende categorieën onderzoekers weergegeven, en het gemiddelde van het totaal.

Tabel 51: Sensitiviteit en specificileit van de verschillende categorieën onderzoekers en de gemiddelde sensitiviteit en specificiteit van de gehele groep.

\begin{tabular}{lrcrc}
\hline & $\begin{array}{c}\text { Gynae- } \\
\text { cologen }\end{array}$ & $\begin{array}{c}\text { Assis- } \\
\text { tenten }\end{array}$ & $\begin{array}{r}\text { Co-assis- } \\
\text { tenten }\end{array}$ & $\begin{array}{r}\text { Gemid- } \\
\text { delden }\end{array}$ \\
\cline { 2 - 5 } & & & & \\
Sensitiviteit (\%) & 48,0 & 49.0 & 57,2 & 51,4 \\
Specificiteit (\%) & 75,1 & 70.5 & 66.4 & 70.7 \\
\hline
\end{tabular}

De sensitiviteit en specificiteit zijn in dit deel van het onderzoek dus beduidend lager en niet in overeenstemming met literatuurgegevens.

De prevalentie van gebroken vliezen in de groep dubieus gebroken vliezen is $39 \%$. De voorspellende waarde van een positieve test is dan $52,6 \%$. Hiermee draagt een positieve varentest nauwelijks bij aan een verantwoorde beslissing dat de vliezen werkelijk zijn gebroken boven het prevalentie-cijfer $(39 \%)$. De voorspellende waarde van een negatieve varentest is $69,4 \%$.

De varentest lijkt een eenvoudige test en er lijkt geen reden aanwezig om te veronderstellen dat specifieke kennis noodzakelijk is voor de beoordeling van de varentest. Om deze hypothese te toetsen werd een niet medicus gevraagd de preparaten ook te bekijken. Het hoofd van de technische dienst behaalde een sensitiviteit van $23,1 \%$ en een specificiteit van $78,7 \%$. Dit percentage is vergelijkbaar met het percentage gescoord door het hoofd van de afdeling obstetrie en gynaecologie van het academisch ziekenhuis Maastricht (sensitiviteit: $28,2 \%$ en specificiteit: $77,1 \%$ ).

Voor de berekening van de inter-waarnemer variatie is de uiteindelijke diagnose niet van belang. Daarom konden bij de 30 onderzoekers alle 120 preparaten worden beschouwd. De kappawaarden zijn berekend, zoals voorgesteld door Schouten (1986). De kappa is een maat van overeenstemming, gecorrigeerd voor toevallige overeenstemming. De "standaard jackknife technique" werd gebruikt om de standaardfout van kappa te berekenen en om de gecorrigeerde kappa-waarden te vergelijken.

De kappa-waarden zijn samengevat in tabel 52 . Ook zijn de verschillen in de mate van overeenstemming tussen de groepen waarnemers weergegeven in tabel 52. 
Tabel 52: Overzicht van de overeenstemming in beoordeling tussen de gemiddelden van de groepen onderzoekers.

Waamemer $\quad$ Kappa \pm S.D. $\quad$ Verschillen
Overeenkomst

Groep

Gynaecologen (G)

Assistenten (A)

Co-assistenten (C)

$\begin{array}{ll}0,80 & 0,60 \pm 0,04 \\ 0,68 & 0.41 \pm 0,04 \\ 0,73 & 0,53 \pm 0,03\end{array}$

G-A: $p<0,001$

G-C: $p<0,050$

A-C: $p<0,001$

De kappa-waarden geven een substantiële overeenstemming aan (Fleiss 1981), maar gemiddeld bij een op de vier patiënten zijn twee beoordelaars het niet met elkaar eens. Dit laatste blijkt uit de waarnemer overeenkomst.

\section{Conclusies}

1. Alleen bij een "zekere" diagnose is de varentest een snelle, goedkope en redelijk betrouwbare methode om aan te tonen dat inderdaad vruchtwater wordt verloren.

2. De betrouwbaarheid van de varentest is echter laag indien deze wordt gebruikt als diagnosticum, voor het al dan niet staan van de vliezen, bij dubieus gebroken vliezen.

3. De waarde van de varentest wordt bovendien ongunstig beïnvloed door de interwaarnemer variatie.

Uit bovenstaande conclusies volgt:

De varentest is ongeschikt om bij patiënten met dubieus gebroken vliezen vruchtwater aan te tonen.

6.4.6 Opname-frequentie na het verrichten van de varentest bij dubieus gebroken vliezen

Zoals in de vorige paragraaf is vermeld gaf de waarnemer ook aan of hij/zij patiënte klinisch wilde observeren, naar aanleiding van de varentest, of haar voor verdere contrôle naar de polikliniek verwees. 
hoofdstuk 6

Als er van wordt uitgegaan dat het terecht is om iemand met gebroken vliezen op te nemen dan kan voor de varentest het aantal malen dat klinisch moest worden geobserveerd en het aantal opnames dat overbodig was worden berekend. De resultaten voor de verschillende onderzoekersgroepen zijn weergeven in tabel 53.

Tabel 53: De gemiddelde opnames die terecht plaats vonden en de klinische observaties die overbodig waren per onderzoekersgroep en het gemiddelde aantal opnames terecht of overbodig voor alle onderzoekers.

\begin{tabular}{rrrrr} 
& Gynaecoloog & Assistent & Co-assistent & Gemiddelden \\
\cline { 2 - 4 } Opname & & & & \\
Terecht(\%) & & & & \\
Overbodig(\%) & 53,9 & 63,3 & 58,0 & 58,4 \\
& 23,6 & 27,4 & 32,6 & 27,9 \\
\hline
\end{tabular}

Tabel 53 geeft weer het percentage patiënten met dubieus gebroken vliezen dat, na beoordeling van alleen de varentest, terecht is opgenomen: gemiddeld iets meer dan de helft.

Ook staat in deze tabel vermeld het percentage patiënten dat wegens dubieus gebroken vliezen is opgenomen, maar bij nader inzien geen gebroken vliezen bleek te hebben. Benadrukt dient te worden dat het een groep patiënten betreft waarbij het voor de onderzoeker onduidelijk is of de vliezen staan dan wel gebroken zijn. Het positief of negatief zijn van deze test geeft dan vaak de doorslag bij het verder te volgen beleid.

Voor het al dan niet opnemen is de mate van overeenstemming berekend. De kappawaarden werden wederom vergeleken volgens de standaard "jackknife technique" beschreven door Schouten (1986).

De mate van overeenstemming is samengevat in tabel 54.

Tabel 54: Mate van overeenstemming van de groepen met betrekking tot het al dan niet opnemen van de patiënte naar aanleiding van het beoordelen van de varentest.

\begin{tabular}{rrrr}
\hline & $\begin{array}{r}\text { waamemer } \\
\text { overeenkomst }\end{array}$ & kappa \pm S.D. & verschil \\
\cline { 2 - 3 } Groep & & & \\
Gynaecologen (G) & 0,85 & $0,67 \pm 0,04$ & G-A: p<0.001 \\
Assistenten (A) & 0,75 & $0,48 \pm 0,04$ & G-C: $p<0,05$ \\
Co-assistenten (C) & 0,79 & $0,58 \pm 0,04$ & A-C: $p<0,01$ \\
\hline
\end{tabular}

De verschillen tussen de mate van overeenstemming zijn significant zoals weergegeven in tabel 54. De gynaecologen hebben de hoogst gemiddelde mate van overeenstem- 
ming, dan volgen de co-assistenten en tenslotte de assistenten. De mate van overeenstemming boven het toeval is teleurstellend. In $20 \%$ van de gevallen bestaat geen overeenstemming. Voor de praktijk betekent het dat bij 1 op de 5 patiënten aan de uitslag een, per onderzoeker, verschillende consequentie wordt verbonden.

Gezien deze resultaten is in dit onderzoek afgezien van het bepalen van de intrawaarnemer variatie.

Uit dit onderzoek blijkt (hoofdstuk 3) het twijfelen aan het staan van de vliezen bij zwangeren (na de $16^{\mathrm{c}}$ week) in ongeveer $5 \%$ voor te komen. In Nederland worden ongeveer 180.000 kinderen per jaar geboren. Van deze 180.000 kinderen wordt bij benadering $55 \%$ geboren onder leiding van de verloskundige of huisarts; ongeveer 80.000 kinderen, worden in het ziekenhuis geboren onder leiding van de gynaecoloog. Bij deze 80.000 partus zou tijdens de zwangerschap bij 4.000 zwangeren (incidentie dubieus gebroken vliezen $5 \%$ ) aan het staan van de vliezen worden getwijfeld. Als verder wordt aangenomen dat de frequentie van het werkelijk gebroken zijn van de vliezen, in de groep met dubieus gebroken vliezen $40 \%$ is, dan zijn in Nederland per jaar 1600 patiënten met werkelijk gebroken vliezen in de dubieuze groep. Van deze patiënten zouden, bij gebruikmaking van de varentest, bijna 320 patiënten (20\%) niet worden opgenomen. De onbekende consequenties van deze foutieve beslissing zouden zeer groot kunnen zijn. Anderzijds hebben bijna 450 patiënten geen gebroken vliezen, van de gehele groep patiënten waarbij men aan het staan van de vliezen twijfelt. Van de groep met staande vliezen wordt immers $28 \%$ ten onrechte opgenomen. Als ook wordt aangenomen dat deze patiënten gemiddeld 5 dagen klinisch worden geobserveerd (met een verpleegprijs van fl $500,--$ per dag) dan kost dit meer dan fl $1.000 .000,--$ per jaar.

\section{Conclusies}

1. De inter-waarnemer variatie beïnvloedt de betrouwbaarheid van de varentest negatief. De consequenties die door een clinicus aan een uitslag van de varentest worden verbonden is bij $20 \%$ van de patiënten afhankelijk van die clinicus.

2. In de groep patiënten met dubieus gebroken vliezen wordt op basis van de varentest niet zelden een verkeerde beslissing genomen. Alleen al de financiële consequenties van die verkeerde beslissing zijn aanzienlijk. 
hoofdstuk 6

\section{- Resultaten van het onderzoek}

\section{$6.5 \mathrm{pH}$-Bepaling}

\subsubsection{Inleiding}

De pH-bepaling wordt samen met de varentest het meest genoemd als betrouwbare test om gebroken vliezen aan te tonen. De aan de $\mathrm{pH}$-bepaling ten grondslag liggende theorie is: in de vagina bestaat een zuur milieu ( $\mathrm{pH} 3$ tot 4 ) en vruchtwater heeft een $\mathrm{pH} \geq 7,0$. Indien vaginale fluor wordt gemengd met vruchtwater dan zal de $\mathrm{pH}$ dus stijgen.

De pH-bepaling, als techniek om gebroken vliezen aan te tonen, is relatief oud en kent vele varianten:

- lakmoespapier

- nitrazinetest

- temesvarytest

- modern pH-indicatorpapier

- pH-meter.

\section{Lakmoespapier}

Het gebruik van lakmoespapier ( $\mathrm{pH}$-indicatorpapier met een omslagpunt van rood naar blauw bij een $\mathrm{pH}=7$ ) om vruchtwater aan te tonen werd voor het eerst in 1927 beschreven (Gold).

Op grond van de resultaten van Gold kan een sensitiviteit worden berekend die gelijk is aan $100 \%$ en een specificiteit van $96,7 \%$. Als bron voor fout-positieve en fout-negatieve uitslagen ziet Gold (1927) desinfectiemiddelen, urine en bloed.

\section{Nitrazinetest}

Ook de nitrazinetest is een reeds lang bekende $\mathrm{pH}$-indicatortest beschreven door Baptisti in 1938. Hij beschrijft het gebruik van papiertjes die gedrenkt zijn in natrium-dinitro-phenylozonaphthol-disulfonaat als test om gebroken vliezen aan te tonen. Het is een $\mathrm{pH}$-indicator die bij een $\mathrm{pH}$ van 6 omslaat van geel naar blauw. De sensitiviteit die kan worden berekend met behulp van de resultaten van Baptisti: 90,9\% en de specificiteit: $100 \%$. 
De Temesvarytest is een indicatortest waarbij gebruik wordt gemaakt van een oplossing van broom-thymol-blauw in alcohol (Temesvary 1933). Deze indicator geeft een omslag van geel naar blauw bij een $\mathrm{pH}=7$.

Modern pH-indicator-papier

Tegenwoordig is $\mathrm{pH}$-indicatorpapier in de handel dat niet een bepaald omslagpunt heeft, zoals de hierboven beschreven tests, maar waarmee binnen een beperkte nauwkeurigheid de actuele $\mathrm{pH}$ kan worden gemeten (Thomason e.a. 1990). Dit is mogelijk daar een aantal pH-indicatoren op een strook zijn aangebracht. De $\mathrm{pH}$ kan aldus met een nauwkeurigheid van $0,2 \mathrm{pH}$-eenheden eenvoudig worden bepaald. Deze methode werd voor dit onderzoek gebruikt.

$\mathrm{pH}$-meter

Het is mogelijk om met een elektronische $\mathrm{pH}$-meter de $\mathrm{pH}$ in het cervicale kanaal te meten. Het nadeel van deze techniek is tweeledig:

- de plaats van de meting kan de uitslag beïnvloeden

- het is een invasieve techniek.

\subsection{2 pH-Bepalingen bij patiënten met een zekere diagnose}

In de groep met een zekere diagnose werd in vaginaal afgelopen vruchtwater, serum. urine. fluor vaginalis en cervixslijm de $\mathrm{pH}$ gemeten met behulp van indicatorpapier. In dit onderzoek werd gebruik gemaakt van "Pehanon" indicatorpapier (Macherey Nagel, Düren, Duitsland). Met behulp van dit papier kan de $\mathrm{pH}$, door kleurvergelijking in het traject van $\mathrm{pH}=1,8$ tot $\mathrm{pH}=12$, in stappen van $0,2 \mathrm{pH}$-eenheden worden gemeten.

De aantallen van de $\mathrm{pH}$-bepaling in de verschillende soorten vocht en de amenorroeduur zijn beschreven in paragraaf 6.2. Daar de $\mathrm{pH}$ van vruchtwater in het verloop van de zwangerschap niet verandert, is in figuur 6 de gemiddelde $\mathrm{pH}$ voor de gehele zwangerschap en de standaarddeviatie weergegeven. 
hoofdstuk 6

Figuur 6: De gemiddelde $\mathrm{pH}$ gemeten in vaginaal afgelopen vruchtwater, serum, urine, fluor vaginalis en cervixslijm met de standaarddeviatie bij 203 patiënten waarbij de diagnose gebroken of staande vliezen zeker is.

\section{Gemiddelde $\mathrm{pH}$}

patiënten met een bekende diagnose

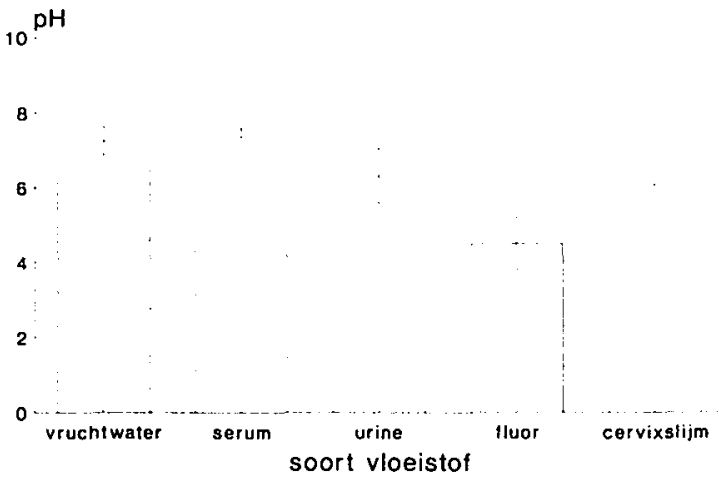

Figuur 6 laat zien dat de $\mathrm{pH}$ van serum vergelijkbaar is met die van vruchtwater. Bloedbijmenging zou dus de oorzaak kunnen zijn van fout-positieve uitslagen. Ook urine kan de betrouwbaarheid van de test negatief beïnvloeden.

In tabel 55 is de frequentieverdeling van $\mathrm{pH}$-waarden van de verschillende lichaamsvloeistoffen vermeld.

Tabel 55: Frequentieverdeling van de pH in klassen van 0.5 pH-eenheden in de verschillende lichaamsvloeistoffen en het aantal uirgevoerde bepalingen.

\begin{tabular}{|c|c|c|c|c|c|}
\hline & $\begin{array}{l}\text { vrucht- } \\
\text { water }\end{array}$ & serum & urine & $\begin{array}{r}\text { fluor } \\
\text { vaginalis }\end{array}$ & cervixslijm \\
\hline \multicolumn{6}{|l|}{$\mathrm{pH}$} \\
\hline$>3,5$ en $\leq 4,0$ & 0 & 0 & 1 & 7 & 1 \\
\hline$>4,0$ en $\leq 4,5$ & 0 & 0 & 0 & 48 & 3 \\
\hline$>4,5$ en $\leq 5,0$ & 0 & 0 & 4 & 12 & 2 \\
\hline$>5.0$ en $\leq 5,5$ & 1 & 0 & 37 & 5 & 0 \\
\hline$>5,5$ en $\leq 6,0$ & 2 & 0 & 26 & 5 & 2 \\
\hline$>6,0$ en $\leq 6,5$ & 1 & 0 & 64 & 0 & 0 \\
\hline$>6,5$ en $<7,0$ & 20 & 0 & 24 & 1 & $\mathbf{i}$ \\
\hline$=7,0$ & 9 & 3 & 3 & 2 & 4 \\
\hline$>7.0$ en $\leq 7.5$ & 93 & 118 & 29 & 0 & 4 \\
\hline$>7.5$ en $\leq 8.0$ & 20 & 70 & 7 & 0 & 1 \\
\hline$>8,0$ en $\leq 8,5$ & 1 & 2 & 3 & 0 & 0 \\
\hline Totaal & 147 & 193 & 198 & 80 & 18 \\
\hline
\end{tabular}


Als wordt verondersteld dat bij staande vliezen vaginaal afgelopen vloeistof een $\mathrm{pH}$ heeft lager dan 7,0 dan is uit tabel 55 te concluderen dat 24 maal deze veronderstelling onjuist is.

Het serum heeft in alle gevallen een pH die hoger of gelijk is aan 7,0. 42 Maal is de $\mathrm{pH}$ van urine hoger of gelijk aan 7,0. Bij fluor vaginalis is dat 2 maal het geval en bij cervixslijm 9 maal. Ook de 5 semenmonsters hadden een $\mathrm{pH}$ die hoger is dan 7,0 (gemiddeld 7,4).

Uit tabel 55 kan ook worden geconcludeerd dat vaginaal afgelopen vloeistoffen, ook als het geen vruchtwater betreft, niet zelden een $\mathrm{pH}$ hebben die hoger of gelijk is aan 7,0 . Tevens is uit tabel 55 af te leiden dat, indien een afkappunt wordt gekozen dat lager is dan $\mathrm{pH}=7$, de sensitiviteit van de methode toeneemt maar ook het aantal fout-positieve uitslagen.

\subsection{3 pH-Bepaling bij patiënten met dubieus gebroken vliezen}

Zoals is beschreven in paragraaf 6.2 bestond de groep met dubieus gebroken vliezen uit 100 patiënten. De pH van het bij deze patiënten afgelopen vocht is weergegeven in tabel 56.

Tabel 56: De frequentieverdeling van de $\mathrm{pH}$ in stappen van $0.5 \mathrm{pH}$-eenheden van vaginaal afgelopen vochs van de groep patiënten met de aanvankelijke diagnose: dubieus gebroken vliezen.

\begin{tabular}{rrr}
\hline & $\begin{array}{r}\text { Staande } \\
\text { vliezen }\end{array}$ & $\begin{array}{r}\text { Gebroken } \\
\text { vliezen }\end{array}$ \\
\cline { 2 - 3 } & & \\
& & \\
$>3.5$ en $\leq 4.0$ & & 0 \\
$>4,0$ en $\leq 4,5$ & 1 & 2 \\
$>4.5$ en $\leq 5.0$ & 18 & 1 \\
$>5,0$ en $\leq 5.5$ & 9 & 2 \\
$>5.5$ en $\leq 6.0$ & 3 & 1 \\
$>6.0$ en $\leq 6.5$ & 4 & 0 \\
$>6.5$ en $<7,0$ & 4 & 15 \\
$=7.0$ & 8 & 0 \\
$>7,0$ en $\leq 7.5$ & 0 & 18 \\
$>7.5$ en $\leq 8.0$ & 11 & 0 \\
aantal & 3 & 39 \\
\end{tabular}

Met behulp van de gegevens van tabel 56 is de sensitiviteit en specificiteit te berekenen als bij gebroken vliezen wordt verondersteld dat de $\mathrm{pH}$ van het afgelopen vocht hoger of gelijk is aan 7: 
hoofdstuk 6

Sensitiviteit $=18 / 39 \times 100 \%=46,2 \%$

Specificiteit $=47 / 61 \times 100 \%=77,0 \%$.

De sensitiviteit is zeer laag en de specificiteit is matig. De predictieve waarde van een positieve testuitslag is: $56,3 \%$ en de predictieve waarde van een negatieve testuitslag is: $69,1 \%$. De prevalentie van gebroken vliezen is, in dit onderzoek, $39 \%$. Als de $\mathrm{pH}$ in het afgelopen vocht wordt bepaald en de uitslag is hoger of gelijk aan 7 dan neemt de kans dat de juiste diagnose wordt gesteld toe ten opzichte van het toeval: 56,3\%. De prevalentie van staande vliezen is, in dit onderzoek, $61 \%$ en na de $\mathrm{pH}$-bepaling neemt de kans, dat de juiste diagnose wordt gesteld ten opzichte van de prevalentie toe, naar $69,1 \%$.

Het afkappunt $(\mathrm{pH}=7)$ moet wellicht anders worden gekozen. Om een beter inzicht te krijgen kan men de sensitiviteit en specificiteit tegen elkaar uitzetten bij verschillende afkappunten. Een "Receiver Operating Characteristic"-curve (ROC-curve) van de pH is weergegeven in figuur 7.

Figuur 7: ROC-curve van $p H$ bij de afkappunten: 3,5 tot 8 met intervallen van 0.5 pH-eenheden.

ROC-curve van de $\mathrm{pH}$

dubieus gebroken vliezen

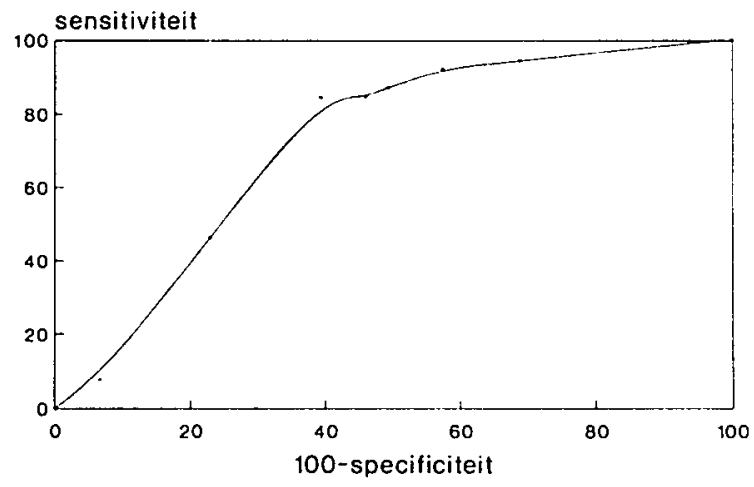

Het optimale afkappunt, gedefinieerd als grootste som van sensitiviteit en specificiteit (Conell en Koepsell 1985), ligt bij pH=6,8. Echter ook bij dit afkappunt wordt een matige sensitiviteit en specificiteit gevonden $(<70 \%)$. Het meten van de $\mathrm{pH}$ is derhalve niet geschikt om de diagnose staande dan wel gebroken vliezen, bij een patiënte met dubieus gebroken vliezen, te stellen. 
diagnostiek

\section{Conclusies}

1. Het meten van de $\mathrm{pH}$ als diagnosticum bij dubieus gebroken vliezen kan ongunstig worden beïnvloed door bijmenging van: bloed, urine, fluor vaginalis, cervixslijm en semen.

2. De sensitiviteit van de $\mathrm{pH}$-bepaling bij dubieus gebroken vliezen is bij een vaak gebruikt afkappunt van 7,0: $46,2 \%$, de specificiteit: $77,0 \%$.

De predictieve waarde van een positieve test bij een afkappunt van $\mathrm{pH} \geq 7,0$ is slechts: 56,3\%; de predictieve waarde van een negatieve test bij een afkappunt van $\mathrm{pH}<7,0: 69,1 \%$.

Uit bovenstaande volgt: het meten van de $\mathrm{pH}$ is ongeschikt om de diagnose staande dan wel gebroken vliezen, in een groep met dubieus gebroken vliezen, te stellen. 
hoofdstuk 6

- Resultaten van het onderzoek

6.6 Nile-blue-sulfaat-test

\subsubsection{Inleiding}

De Nile-blue-sulfaat-kleuring van vruchtwater is gebaseerd op het aantonen van neutraal vet, mogelijk vernix caseosa; dit vet kleurt met Nile-blue geel/oranje (Brosens en Gordon 1965). De test werd voor het eerst beschreven in 1963 (Kittrich) (paragraaf 2.5.2). Kittrich, Brosens en Gordon vermeldden een sensitiviteit en specificiteit die hoger is dan 95\%; zij beschreven groepen patiënten waar men zeker was van de diagnose staande dan wel gebroken vliezen.

Ondanks de hoge sensitiviteit en specificiteit gaven Kittrich, Brosens en Gordon aan dat vernix caseosa pas na de $32^{\mathrm{e}}$ week van de zwangerschap in vruchtwater voorkomt. Dit betekent dat de Nile-blue-kleuring voor de $32^{\circ}$ week vaak negatief zal zijn. Ook zien de auteurs contaminatie van fluor vaginalis als een mogelijke bron van verkeerde uitslagen.

Deze test is, merkwaardigerwijs, bijna alleen terug te vinden in overzichtsartikelen die de diagnostiek van het gebroken zijn van de vliezen beschrijven (Lange Friedman en McElin 1969, Gunn e.a. 1970 en Smith 1976). Andere onderzoekers zijn blijkbaar niet overtuigd van de waarde van de test.

\subsubsection{Methode van de Nile-blue-sulfaat-kleuring}

Van het te onderzoeken vocht wordt I druppel op een objectglas gebracht en gemengd met een druppel van een $0,1 \%$ oplossing van Nile-blue-sulfaat. Na het aanbrengen van een dekglas kan het preparaat, zonder fixatie, onder de microscoop bij een vergroting van 100 maal of meer worden bekeken. Een preparaat wordt positief genoemd als minstens én oranje "cel" zonder kern (mogelijk een vetbol) wordt gezien (figuur 3 ). Als deze "cel" niet wordt aangetroffen is het preparaat negatief.

De hele procedure is goedkoop, simpel en kost weinig tijd (10 minuten).

\subsubsection{Nile-blue-sulfaat-kleuring bij patiënten met een zekere diagnose}

Van vruchtwater, serum, urine, fluor vaginalis en cervixslijm, verkregen bij patiënten waarbij de diagnose staande of gebroken vliezen zeker was, is een Nile-bluesulfaat-kleuring uitgevoerd. De preparaten moesten direct worden gemaakt en beoordeeld zoals beschreven in paragraaf 2.5.2. 
Het meest representatieve gedeelte van het preparaat werd fotografisch vastgelegd. De resultaten zijn samengevat in tabel 57.

Tabel 57: Resultaten van de Nile-blue-sulfaat-kleuring in vruchtwater (vrw.), serum (ser.), urine (uri.), fluor vaginalis (flu.) en cervixslijm (cerv.) bij verschillende amenorroeklassen en het aantal uitgevoerde bepalingen.

\begin{tabular}{|c|c|c|c|c|c|c|c|c|c|c|}
\hline \multirow[b]{2}{*}{$\begin{array}{r}\text { amenorroe } \\
\text { (weken) }\end{array}$} & \multirow[t]{2}{*}{$\begin{array}{c}\text { vrw. } \\
+\end{array}$} & \multirow[t]{2}{*}{$\begin{array}{r}\text { vrw. } \\
-\end{array}$} & \multirow[t]{2}{*}{$\begin{array}{r}\text { ser. } \\
+\end{array}$} & \multirow[t]{2}{*}{$\begin{array}{r}\text { ser. } \\
-\end{array}$} & \multirow[t]{2}{*}{$\begin{array}{r}\text { uri. } \\
+\end{array}$} & \multirow[t]{2}{*}{$\begin{array}{r}\text { uri. } \\
-\end{array}$} & \multirow[t]{2}{*}{$\begin{array}{r}\text { flu. } \\
+\end{array}$} & $\begin{array}{r}\text { flu. } \\
-\end{array}$ & + & erv. \\
\hline & & & & & & & & & & \\
\hline 16 tot 20 & 2 & 10 & 0 & 18 & 0 & 18 & 0 & 12 & 0 & 1 \\
\hline 20 tot 24 & 4 & 6 & 0 & 18 & 0 & 19 & 0 & 9 & 0 & 0 \\
\hline 24 tot 28 & 4 & 10 & 0 & 17 & 0 & 20 & 0 & 6 & 0 & 0 \\
\hline 28 tot 32 & 10 & 2 & 0 & 26 & 0 & 26 & 0 & 15 & 0 & 1 \\
\hline 32 tot 36 & 19 & 6 & 0 & 31 & 0 & 33 & 0 & 12 & 0 & 2 \\
\hline 36 tot 42 & 73 & 1 & 1 & 82 & 0 & 82 & 2 & 24 & 0 & 14 \\
\hline Totaal & 112 & 35 & 1 & 192 & 0 & 198 & 2 & 78 & 0 & 18 \\
\hline
\end{tabular}

Uit tabel 57 blijkt dat er weinig fout-positieve en fout-negatieve uitslagen zijn, alleen voor de $28^{c}$ week wordt vruchtwater vaak fout-negatief beoordeeld.

Dit laatste fenomeen is als volgt te verklaren. De troebeling van het vruchtwater, die meestal ontstaat na de $34^{\mathrm{c}}$ tot $35^{\mathrm{c}}$ week van de zwangerschap, loopt parallel aan de ontwikkeling van de zweetklieren. Immers door zweetproduktie kan vernix caseosa emulgeren en eerst dan in vruchtwater worden aangetoond. Zweetklieren kunnen vanaf de $13^{\mathrm{c}}$ tot $16^{\mathrm{c}}$ week worden aangetoond op de handpalmen en voetzolen van de foetus; vanaf de $28^{\mathrm{c}}$ tot $32^{\mathrm{c}}$ week krijgen de secretoire cellen hun karakteristiek volwassen aspect. De neurotransmitter voor de zweetklieren is acetylcholine; functioneel zijn zweetklieren dus cholinergische structuren, die door anticholinergica worden geremd. Een onverklaarde paradox is dat deze cholinergische eccriene zweetklieren ook door intradermale toediening van adrenaline tot secretie kunnen worden gebracht. Derhalve kan door een directe werking van circulerende catecholaminen de secretie door zweetklieren worden verklaard. Deze werking is dosis- c.q. concentratie-afhankelijk (Voets 1975). 
hoofdstuk 6

Het voorkomen van positieve Nile-blue-sulfaat-kleuringen voor de $30^{\circ}$ week van de zwangerschap zou kunnen worden verklaard door een hoge concentratie van catecholaminen, vroeg in de zwangerschap.

Bij een partus immaturus of prematurus kan de concentratie van catecholaminen inderdaad verhoogd zijn, door stress. Maar ook bij dysmaturitas, ten gevolge van een placenta-insufficiëntie, bestaat de mogelijkheid dat de catecholamines bij de foetus, ten gevolge van stress, toenemen. Ook speelt de concentratie van moederlijke catecholaminen een rol bij de prikkelbaarheid van de uterus (Amy en Karim 1978). Deze verhoogde catecholaminen kunnen mogelijk de zweetklieren van de foetus beïnvloeden.

Indien ervan wordt uitgegaan dat eerst vanaf 28 weken amenorroe de zweetklieren kunnen functioneren, dan is het uiterst merkwaardig dat in de groep onder de 28 weken toch positieve Nile-blue-sulfaat kleuringen van vruchtwater worden gevonden. De verklaring zou kunnen zijn dat onder invloed van stress de rijping van de foetus, en ook van de zweetklieren, sneller verloopt dan normaal. Dit onderzoek bevestigt de bovenstaande hypothese:

in de groep met een negatieve Nile-blue-sulfaat-kleuring voor de $28^{e}$ week van de zwangerschap (26 patiënten) zijn 3 kinderen in utero overleden; zes kinderen in deze groep overleden durante partu, 17 maal trad geen perinatale sterfte op. In de groep met een positieve Nile-blue-sulfaat-kleuring van vruchtwater (10 patiënten) zijn 7 kinderen intra-uterien overleden; twee kinderen overleden durante partu, slechts eenmaal trad geen perinatale sterfte op.

Het geringe aantal patiënten laat statistische bewerking niet toe.

Tabel 57 laat verder zien dat er in andere lichaamsvloeistoffen dan vruchtwater nauwelijks fout-positieve Nile-blue-sulfaat-kleuringen worden gevonden (slechts 3 maal).

De Nile-blue-kleuring werd verricht bij een groep patiënten waarbij de vliezen of waren gebroken (de bepaling werd verricht in vruchtwater) of zeker niet waren gebroken (de bepaling werd verricht in een ander vocht). De volgende sensitiviteit en specificiteit kan dan worden berekend:

sensitiviteit $=112 / 147=76,2 \%$

specificiteit $=486 / 489=99,4 \%$.

De oorzaak van de relatief lage sensitiviteit werd hierboven verklaard; het verband met de amenorroeduur wordt in figuur 8 zichtbaar gemaakt. 
Figuur 8: Het aantal positieve en negatieve Nile-blue-kleuringen bij verschillende amenorroeklassen.

\section{Nile-blue-sulfaat-test \\ resultaten versus amenorroe}

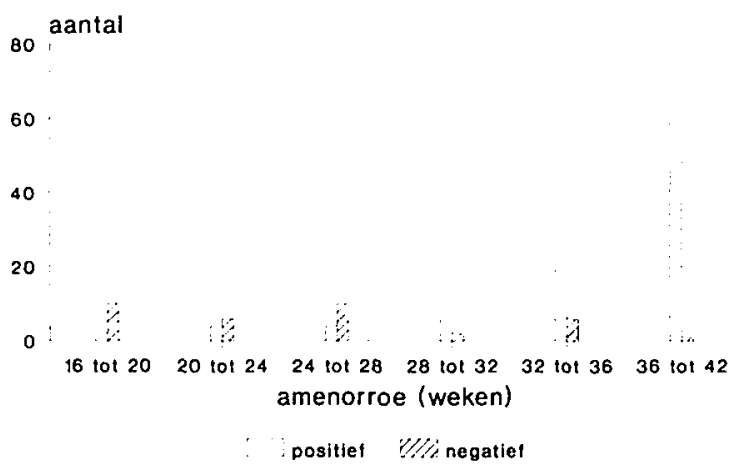

Voor de $36^{\mathrm{c}}$ week is het aantal fout-negatieve uitslagen hoog (sensitiviteit in deze subgroep: $53,4 \%$ ). Doordat na de $36^{\mathrm{e}}$ week het aantal fout-negatieven laag is $(1,4 \%)$ is de sensitiviteit in die periode hoog $(98,6 \%)$. De specificiteit voor en na de $36^{\mathrm{C}}$ week is 100 , respectievelijk $98,5 \%$. In de gehele groep (voor en na de $36^{\mathrm{e}}$ week) is de sensitiviteit $76,2 \%$ en de specificiteit $99,4 \%$ (figuur 8 ).

\section{Conclusie}

De Nile-blue-sulfaat-kleuring heeft bij een zekere diagnose een redelijke betrouwbaarheid: sensitiviteit $76,2 \%$, specificiteit $99,4 \%$. De betrouwbaarheid is echter sterk afhankelijk van de amenorroeduur: vóor de $36^{\circ}$ week is de sensitiviteit $53,4 \%$ en de specificiteit 100\%; nà de $36^{\circ}$ week is de sensitiviteit $98,6 \%$ en specificiteit is $98,5 \%$. De Nile-blue-sulfaat-kleuring zou na de $36^{\mathrm{c}}$ week een betrouwbaar diagnosticum kunnen zijn, ook bij dubieus gebroken vliezen.

\subsubsection{Nile-blue-sulfaat-kleuring bij patiënten met dubieus gebroken vliezen}

De resultaten van de Nile-blue-sulfaat-test in deze groep, bestaande uit de eerder vermeldde (paragraaf 6.2) 100 patiënten zijn als volgt (tabel 58): 
hoofdstuk 6

Tabel 58: Uitslagen van de Nile-blue-sulfaal-kleuring (N.b.-lest) bij patiënten met dubieus gebroken viezen bij de verschillende amenorroeklassen en het aantal uitgevoerde bepalingen.

\begin{tabular}{lrlr}
\multicolumn{1}{r}{$\begin{array}{c}\text { staande } \\
\text { vliezen }\end{array}$} & & \multicolumn{2}{c}{$\begin{array}{l}\text { gebroken } \\
\text { vliezen }\end{array}$} \\
positieve & negatieve & positieve & negatieve \\
N.b.test & N.b.test & N.b.-test & N.b.-test \\
\hline
\end{tabular}

amenorroe

(weken)

16 tot 20

20 tot 24

24 tot 28

28 tot 32

32 tot 36

36 tot 42

$\begin{array}{lr}0 & 0 \\ 0 & 3 \\ 0 & 1 \\ 0 & 6 \\ 1 & 10 \\ 2 & 38\end{array}$

0

3

1

6

10

38

3

58

$\begin{array}{rr}1 & 0 \\ 1 & 2 \\ 0 & 1 \\ 0 & 1 \\ 6 & 3 \\ 15 & 9\end{array}$

aantal

23

16

Uit tabel 58 is de sensitiviteit en specificiteit te berekenen. Voor de gehele groep met dubieus gebroken vliezen zijn de resultaten voor de Nile-blue-sulfaat-kleuring:

sensitiviteit: $23 / 39 \times 100 \%=59,0 \%$

specificiteit: $58 / 61 \times 100 \%=95,1 \%$

De voorspellende waarde van een positieve test is dan: $88,5 \%$ en van een negatieve test: $78,4 \%$.

De sensitiviteit voor de $36^{\mathrm{c}}$ week is $53,3 \%$ de specificiteit: $95,2 \%$. Na de $36^{\mathrm{c}}$ week zijn deze waarden: $62,5 \%$ en $95,0 \%$. De voorspellende waarde van een positieve uitslag van de kleuring na de $36^{\text {c }}$ week is: $88,2 \%$ en de voorspellende waarde van een negatieve test is $80,9 \%$. Met name de sensitiviteit na de $36^{\circ}$ week valt tegen, als de resultaten van de bepalingen in ogenschouw worden genomen zoals beschreven in de vorige paragraaf. Een verklaring voor dit verschil zou kunnen zijn de herkomst van het hier onderzochte vocht (van patiënten met dubieus gebroken vliezen). 
diagnostiek

Conclusies

1. De sensitiviteit van de Nile-blue-sulfaat-kleuring is $59,0 \%$, de specificiteit $95,1 \%$. De voorspellende waarde van een positieve test is $88,5 \%$ die van een negatieve test $78,4 \%$.

2. De Nile-blue-sulfaat-kleuring heeft na de $36^{\mathrm{e}}$ week nauwelijks een hogere sensitiviteit. 
hoofdstuk 6

- Resultaten van het onderzoek

\subsection{Prolactinebepaling}

\subsubsection{Inleiding}

Hoewel dierlijk prolactine al langer bekend was, is het humane prolactine eerst sinds 1971 betrouwbaar aan te tonen (Hwang e.a. 1971). Aanvankelijk kon prolactine alleen door middel van een Radio-Immuno-Assay-bepaling (R.I.A.) worden aangetoond. De R.I.A.-bepalingen zijn arbeidsintensief, duur en alleen met speciale voorzorgsmaatregelen uit te voeren. Sinds 1985 worden er ook I.R.M.A.(Immuno-RadioMetrische Assay)-bepalingen gebruikt. Deze onderscheiden zich vooral van de R.I.A.-bepalingen doordat hierbij het antilichaam is gelabeld in plaats van het antigeen. Inmiddels is het ook mogelijk om het prolactine te bepalen zonder gebruik te maken van radioactieve isotopen (b.v. Enzyme Linked Immunosorbent Assay en ImmunoFluorimetrische Assay). Het voordeel van deze laatstgenoemde bepalingen is dat zij in elk ziekenhuislaboratorium kunnen worden uitgevoerd.

Prolactine komt in vruchtwater voor (Tyson, e.a. 1972) en kan hierin worden aangetoond vanaf de achtste week van de zwangerschap. De concentratie stijgt daarna sterk en bereikt de hoogste waarde rond de $15^{\circ}$ tot $20^{\circ}$ week van de zwangerschap. Daarna daalt de concentratie om na de dertigste week een constante waarde (plateau-waarde) te bereiken (Schindler 1982, de Bakker 1986).

De concentratie van prolactine in vruchtwater heeft geen relatie met de concentratie die wordt gevonden in het serum van de moeder of van de foetus (Andersen 1982, Biswas 1976, Botta e.a. 1982, Fang en Kim 1975, Friesen e.a. 1972, Josimovich e.a. 1974, Luciano en Varner 1984, Rigg en Yen 1977, Schenker e.a. 1975, Soria e.a. 1977).

De serum prolactine-concentraties bij moeder en foetus stijgen gedurende de zwangerschap. De hoogste waarde wordt, bij zowel moeder als kind, gemeten rond de veertigste zwangerschapsweek.

Hoewel de concentratie van het prolactine in het vruchtwater daalt na de $20^{\circ}$ week en de serumwaarden bij moeder en kind blijven stijgen, blijft er altijd een ruim verschil (steeds meer dan een factor 2) in concentratie ten voordele van het vruchtwaterprolactine bestaan (Luciano en Vamer 1984, Schenker e.a. 1975, Soria e.a. 1977). De serum-concentraties van prolactine bij moeder en foetus in het verloop van de zwangerschap zijn weergegeven in figuur 9. 
Figuur 9: Concentratie van prolactine in het vruchtwater, maternaal serum en serum van de foetus (Schindler 1982).

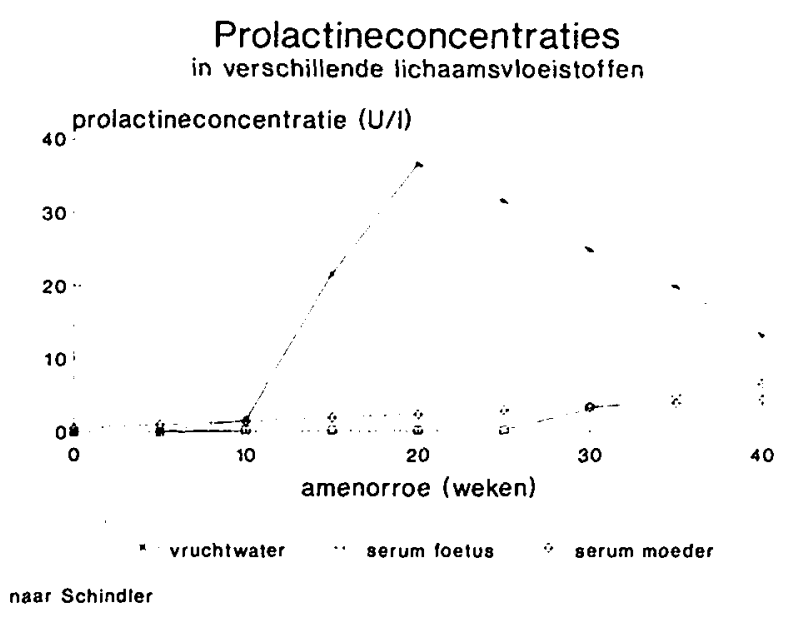

Aangenomen wordt dat het prolactine in het vruchtwater wordt geproduceerd door de decidua (Bender Braverman e.a. 1984, Frame e.a. 1979, Fukamatsu e.a. 1984, Golander e.a. 1978, Healy e.a. 1977 en 1979, Handwerger e.a. 1984, Kasai e.a. 1982, Kubota e.a. 1981, McCoshen e.a. 1982b, McCoshen en Barc 1985, Riddick e.a. 1978, Riddick en Daly 1982, Rosenberg e.a. 1980).

Prolactine kan het chorion- en amnionvlies niet passief passeren; er is een actief transport van het prolactine vanuit de deciduacel naar de amnionholte. Het bewijs hiervoor werd geleverd met in vitro experimenten (Schenker e.a. 1979, Riddick en Maslar 1981, McCoshen e.a. 1982a); welke processen hiervoor verantwoordelijk zijn is tot heden niet bekend.

Bovenstaande gegevens, gecombineerd met de wetenschap dat in urine nooit en in fluor vaginalis en cervixslijm slechts in geringe concentraties prolactine aantoonbaar zijn (paragraaf 6.7.4), maken op theoretische basis de bepaling van het prolactine tot een geschikte test om aan te tonen of de vliezen staan dan wel zijn gebroken. Deze diagnostische mogelijkheid is door andere auteurs reeds beschreven (Koninckx e.a. 1981, Huber e.a. 1983, Phocas e.a. 1989). Huber e.a. (1983) vonden bij hun onderzoek naar de betrouwbaarheid van de prolactine-concentratie in vaginaal afgelopen vocht ook bij staande vliezen een concentratie prolactine die zou kunnen wijzen op gebroken vliezen. Deze verhoogde concentraties kunnen worden veroorzaakt door bloedbijmenging. Anderzijds vonden zij bij patiënten met gebroken vliezen lage concentraties prolactine in vaginaal afgelopen vocht. Dit zou kunnen worden veroorzaakt door een verdunningseffect. Immers kleine hoeveelheden vruchtwater worden dan vermengd met fluor vaginalis en/of urine. 
hoofdstuk 6

\subsubsection{Bepalingsmethode van prolactine}

Het principe van de prolactine-bepaling

De prolactine-bepalingen, uitgevoerd in dit onderzoek, zijn verricht met een Immuno-Fluori-Metrische Assay (I.F.M.A.). Het voordeel van deze methode is, dat ook deze in elk ziekenhuislaboratorium is uit te voeren. Als label wordt een element uit de Lanthanide reeks, Europium, gebruikt. Dit element kenmerkt zich bij fluorescentie door een grote Stokes-shift (het verschil tussen de golflengte van de ingestraalde energie en het uitgezonden licht). Verder treedt in zeker opzicht fosforescentie op: na het wegvallen van de excitatie houdt de emissie nog enige tijd aan. Aangezien nietspecifieke fluorescenties slechts van zeer korte duur zijn is het mogelijk om deze te onderscheiden van de fluorescentie die van het Europium afkomstig is. Door combinatie van deze twee eigenschappen wordt een zeer goede signaal/ruis verhouding bereikt. De techniek wordt veelal aangeduid met de term "Delfia", hetgeen staat voor "Dissociation Enhanced Lanthanide Fluoricent Immuno Assay". De Delfia prolactinebepaling maakt gebruik van de sandwich-techniek: een eerste monoclonaal antilichaam is covalent gekoppeld aan een vaste drager. Dit antilichaam is gericht tegen een epitoop op het prolactine-molecuul. Verder wordt een tweede monoclonaal antilichaam gebruikt dat is gericht tegen een ander epitoop op het prolactine-molecuul, zodat het prolactine-molecuul als het ware is ingesloten tussen twee antilichamen (vandaar de naam "sandwich"-techniek). Tevens draagt het tweede antilichaam het Europium-label. In figuur 10 is de sandwich-reactie weergegeven.

Figuur 10: De schematische weergave van het reactiepatroon bij de prolactine-(PRL)bepaling.

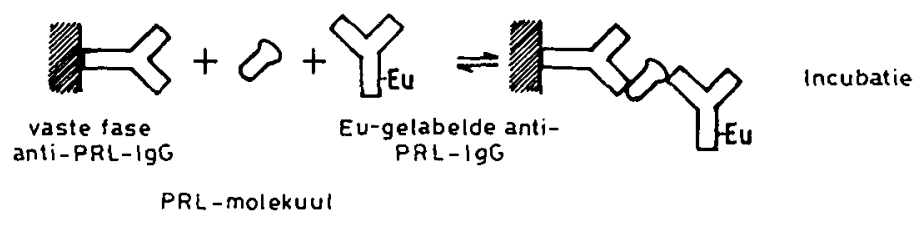

Bij de analyse wordt een "simultane" procedure gevolgd: dat wil zeggen de benodigde reagentia en het te analyseren monster worden gelijktijdig aan het reactiemedium toegevoegd. Na afloop van de incubatieperiode worden de micro-titer-strips gewassen. Vervolgens wordt met behulp van een specifieke oplossing (de "enhanced solution") het $\mathrm{Eu}^{3+}$ gedissocieerd van de gelabelde antilichamen. Daardoor worden fluorescerende chelaten in de oplossing gevormd (figuur 11). 
Figuur 11: De schematische weergave van het tweede deel van de prolactine-bepaling.

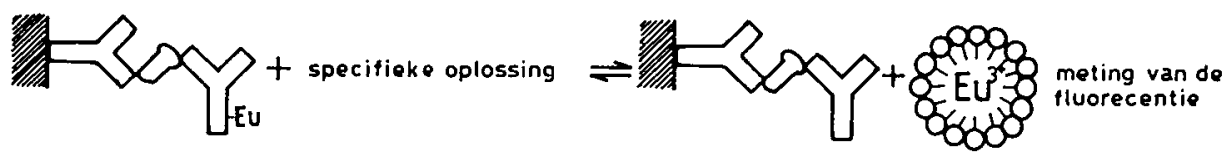

In een speciaal ontworpen fluorescentie-meter ("time resolved" fotometer, type Arcus, firma Pharmacia) wordt de fluorescentie gemeten.

\subsubsection{Calibratie van de prolactinebepaling}

De prolactine-waarden worden berekend met behulp van de meegeleverde standaardreeks. Deze bestaat uit 7 standaarden in het bereik van 0 tot 9 U/1. Deze standaarden zijn geijkt versus het eerste W.H.O.-referentiepreparaat, het Medical Research Counsel (MRC) 75/504. Bij controle van deze calibratie werd gevonden dat de regressiecoëfficiënt significant afwijkt van $1,00(p<0,01)$. De asafsnede blijkt niet significant verschillend van nul te zijn. Er zou dan ook geconcludeerd mogen worden dat de prolactineconcentraties $24 \%$ te hoog worden gevonden. In figuur 12 is de lineaire regressie tussen de theoretische en de gevonden waarden van de verdunningen van dit referentiepreparaat grafisch weergegeven.

Figuur 12: Theoretische prolactine concentraties versus (MRC 75/504) gemeten concentraties prolactine bij verdunning in humane matrix.

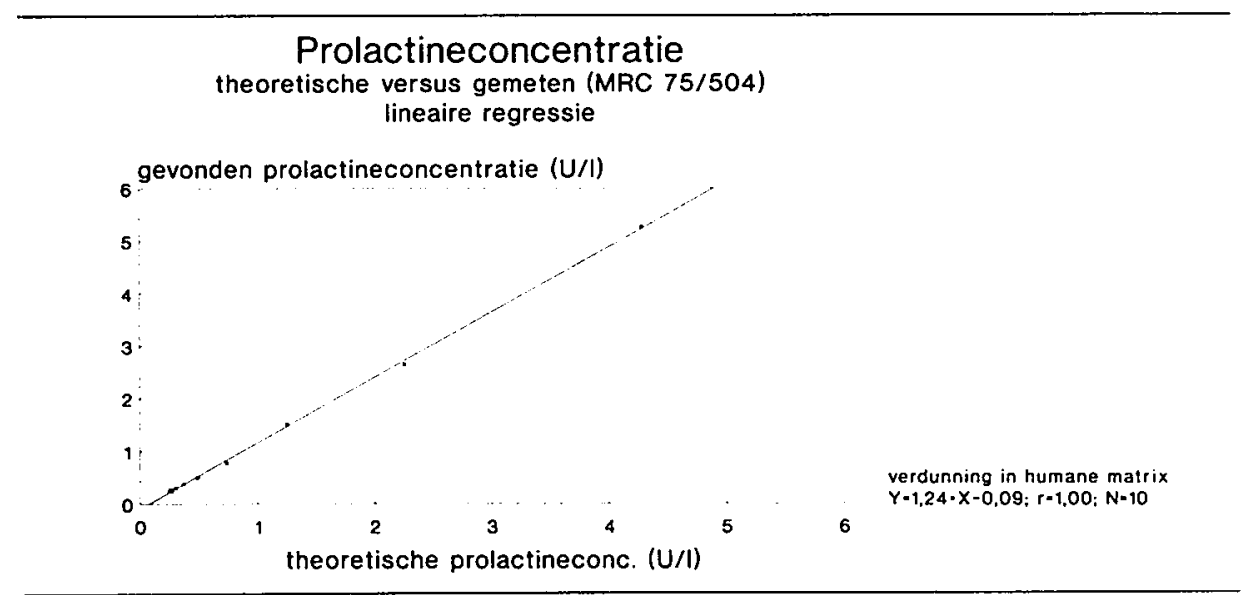


hoofdstuk 6

Vanwege het gevonden calibratie-verschil is ook een verdunningsreeks ingezet met het nieuwe W.H.O.-referentie-preparaat MRC 81/541 (figuur 13).

Figuur 13: Theoretische concentraties prolactine (MRC 81/54I) versus gevonden concentraties prolactine bij verdunning in humane matrix.

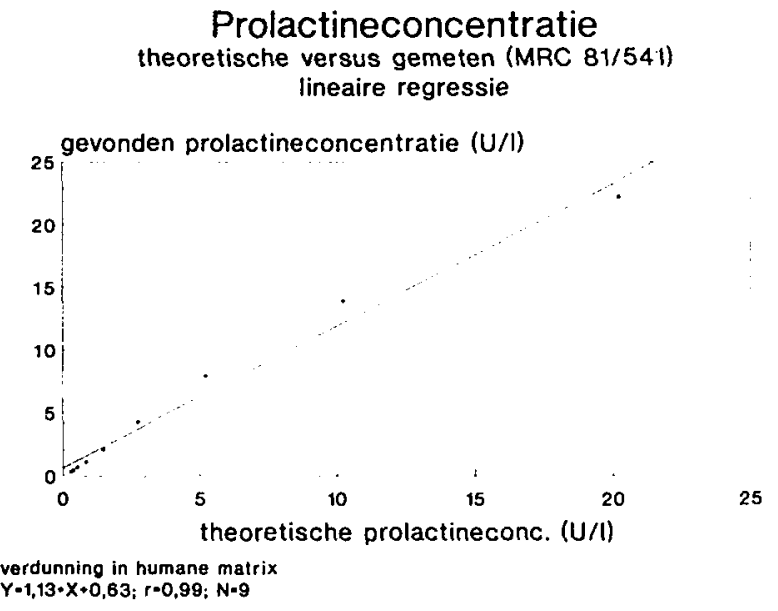

Het betrouwbaarheidsinterval van de regressiecoëfficiënt van de calibratie versus MRC $81 / 504\{1,242<\mathrm{r}(\mathrm{MRC} 75 / 504)<1,244\}$ vertoont een overlap met dat van de calibratie versus MRC 81/541 $\{1,007<\mathrm{r}(\mathrm{MRC75/541)}<1,256\}$ waarbij $\mathrm{p}=0,05$. Hieruit mag worden geconcludeerd dat deze regressies niet significant van elkaar verschillen. Ondanks het feit dat de calibratie van de kit dus mogelijk significant te laag is, is toch besloten om deze niet aan te passen. Reden hiervoor is het feit dat de gevonden waarden bij patiënten met een zekere diagnose waren aangepast aan de kit-calibratie. Uit de variantie in de nul-standaard is de onderste detectiegrens vastgesteld. Deze bleek 0,002 U/1 te bedragen (gemiddelde standaard $0 \pm 3$ S.D.).

Bepalingen van het hier gebruikte type (homogeen systeem) kunnen gemakkelijk worden gestoord door velerlei interferenties. Een daarvan is het zogeheten "high dose hook effect". Hierbij is geen evenredige relatie tussen concentratie van het analyt en de respons van het meetsysteem. De responsparameter wordt kleiner naarmate de concentratie toeneemt en dit leidt tot meting van veel te lage concentraties. Uit de verdunningscurven (figuur 12 en 13) van de MRC-preparaten blijkt dat tenminste tot een niveau van $9 \mathrm{U} / \mathrm{l}$ er voor de prolactine geen sprake is van een high dose hook effect.

Dat bovenstaande conclusie ook geldt voor patiëntenmonsters blijkt uit figuur 14 en 15. In deze figuren zijn de verdunningsreeksen weergegeven van een tweetal patiëntenserummonsters. 
Figuur 14: Patiënte 1: theoretische concentratie versus gevonden concentratie prolactine van een serummonster met een initieel hoge prolactineconcentratie.

\section{Delfia Prolactinebepaling verdunning van een patiëntenmonster}

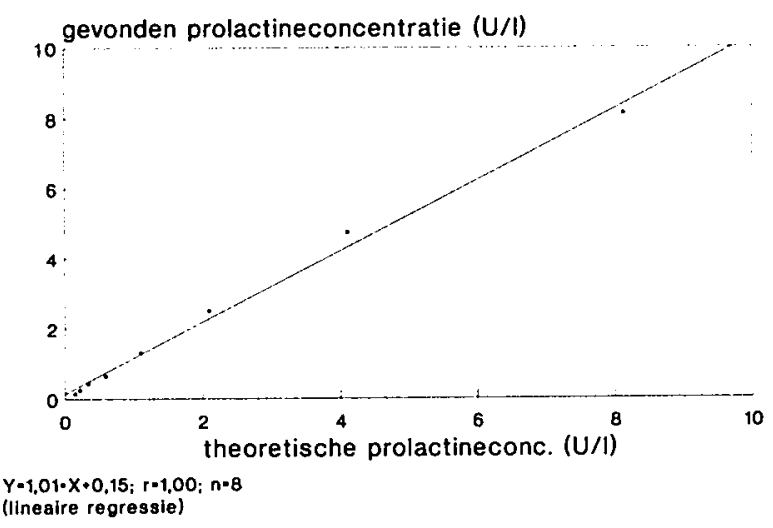

Figuur 15: Patiënte 2: theoretische concentratie versus gevonden concentratie prolactine in een monster met een initieel hoge prolactineconcentratie.

\section{Delfia Prolactinebepaling}

verdunning van een patiëntenmonster

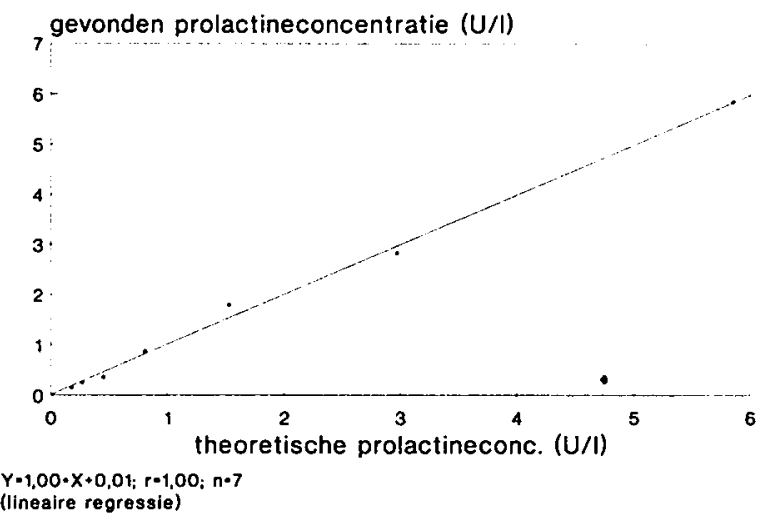

Uit figuur 14 en 15 blijkt dat er een lineaire relatie is tussen de berekende en de gemeten concentraties. Tevens kan worden geconcludeerd dat geen matrixeffecten optreden indien het te bepalen analyt wordt verdund met verschillende media (onder andere urine, vruchtwater, $0,1 \mathrm{M}$ Sörrensenbuffer of $0,9 \% \mathrm{NaCl}$ ). 
hoofdstuk 6

Bij 5 urinemonsters bleek een gemiddelde recovery van $98 \pm 5 \%$ te worden gevonden van de toegevoegde interne prolactinestandaard.

Bij tweepunts-verdunningen $(1: 100 ; 1: 1000)$ van 5 vruchtwatermonsters met een interne standaard was de recovery voor:

0,9\% NaCl-oplossing: $100-103 \%$.

Indien fysiologisch zout gebruikt werd bij serum, fluor vaginalis en cervixslijm traden evenmin matrixeffecten op.

\subsubsection{Prolactinebepaling bij patiënten met een zekere diagnose}

Ter vaststelling van het referentiegebied werd bij patiënten met een zekere diagnose vocht verzameld bij een zekere amenorroeduur.

De aantallen vruchtwater, serum, urine, fluor vaginalis en cervixslijm-monsters voor de prolactinebepaling bij patiënten met een zekere diagnose zijn vermeld in tabel 59.

Tabel 59: Het aantal bepalingen dat in de verschillende amenorroe-intervallen is uitgevoerd ter verkrijging van de referentiewaarden voor prolactine in de verschillende lichaamsvloeistoffen.

\begin{tabular}{crrrrr}
\hline & $\begin{array}{r}\text { vrucht- } \\
\text { water } \\
\mathrm{n}=142\end{array}$ & serum & urine & $\begin{array}{r}\text { fluor } \\
\text { vaginalis } \\
\mathrm{n}=59\end{array}$ & $\begin{array}{r}\text { cervix- } \\
\text { slijm } \\
\mathrm{n}=15\end{array}$ \\
\cline { 2 - 6 } & & & $\mathrm{n}=72$ & & \\
amenorroe & & & & & \\
(weken) & 11 & 17 & 7 & 6 & 1 \\
16 tot 20 & 8 & 18 & 10 & 6 & 0 \\
20 tot 24 & 13 & 17 & 5 & 6 & 0 \\
24 tot 28 & 12 & 26 & 10 & 10 & 1 \\
28 tot 32 & 24 & 31 & 14 & 11 & 1 \\
32 tot 36 & 74 & 82 & 26 & 20 & 12 \\
36 tot 42 & & & & & \\
\hline
\end{tabular}

Tabel 59 laat zien dat het aantal patiënten waarbij cervixslijm kon worden verzameld veel minder is dan het aantal van de andere soorten lichaamsvocht dat werd verzameld. De oorzaak hiervoor is reeds beschreven in paragraaf 6.2.

De resultaten worden weergegeven in figuur 16. 
Figuur 16: De concentraties \pm S.D. van prolactine in her vruchswater, serum, fluor vaginalis en cervixslijm in klassen van amenorroe bij patiënten met een zekere diagnose.

\section{Prolactineconcentratie \\ bij een bekende diagnose}
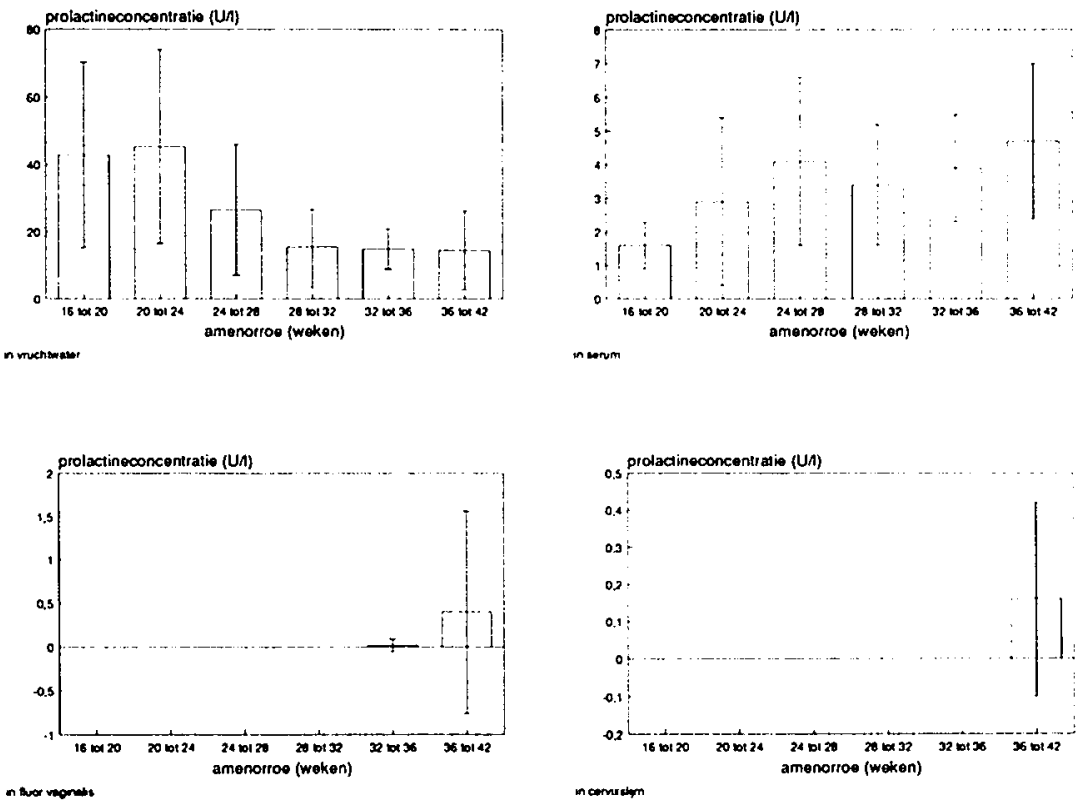

Ook in het semen van 5 fertiele mannen werd prolactine bepaald. Er bleek prolactine aantoonbaar in het semen: laagste concentratie $0,17 \mathrm{U} / 1$ en de hoogste $0,56 \mathrm{U} / \mathrm{l}$.

De prolactineconcentratie in vruchtwater

Uit figuur 16 kan worden geconcludeerd dat de concentratie van prolactine in vaginaal afgelopen vruchtwater zowel in het verloop van de zwangerschap als tussen individuen binnen een amenorroeklasse sterk kan verschillen. De standaarddeviatie is dan ook groot. In totaal werden 142 vruchtwatermonster onderzocht op de aanwezigheid van prolactine; de laagst gevonden waarde was 0,2 U/l, de hoogste $99 \mathrm{U} / \mathrm{l}$. Deze grote concentratieverschillen zouden kunnen worden veroorzaakt door het verdunningseffect 
hoofdstuk 6

van andere lichaamsvloeistoffen (bloed, urine, fluor vaginalis, cervixslijm en semen) bij het verlies van kleine hoeveelheden echt vruchtwater.

In vaginaal afgelopen "vruchtwater" (figuur 16) is dezelfde trend te ontdekken wat betreft de concentratie van prolactine uitgezet tegen de amenorroeduur als die door andere onderzoekers wordt beschreven in "puur" vruchtwater (paragraaf 6.7.1). De concentratie van het prolactine stijgt na de $16^{\mathrm{c}}$ week van de zwangerschap en heeft een piek rond de $20^{\circ}$ tot $24^{\circ}$ week van de zwangerschap; daarna daalt de concentratie van het prolactine naar een plateauwaarde die wordt bereikt tussen de $28^{\mathrm{e}}$ en $32^{\circ}$ week van de zwangerschap. Zelfs de absolute concentraties van prolactine in vaginaal afgelopen vruchtwater zijn vergelijkbaar met puur vruchtwater; maar in het individuele geval is het mogelijk dat de prolactineconcentratie in het "pure" vruchtwater een andere waarde heeft dan in het vaginaal afgelopen vocht. Met name bloedbijmenging kan bij vaginaal afgelopen "vruchtwater" de individuele uitslag sterk beïnvloeden, zeker wanneer het gaat om kleine hoeveelheden vaginaal afgelopen vruchtwater.

De prolactineconcentratie in serum

In totaal werden 191 serummonsters onderzocht. De serumconcentratie van het prolactine neemt gedurende de zwangerschap toe (figuur 16). De resultaten zijn congruent aan de bevindingen van eerdere onderzoekers (Schindler 1982, de Bakker 1986).

Voor elke amenorroeduurklasse geldt: hoewel de spreiding van de serumwaarden minder groot is dan bij de vruchtwatermonsters wordt gevonden, zijn de concentratieverschillen toch groot te noemen.

De prolactineconcentratie in urine

In het totaal werd in 72 urinemonsters prolactine bepaald, per amenorroeklasse minstens 5. Geen enkel monster had een concentratie groter dan 0,002 U/1. Derhalve werd in de andere monsters deze bepaling niet uitgevoerd.

De prolactineconcentratie in fluor vaginalis

Er werden 59 fluormonsters verkregen en onderzocht bij de diagnose staande vliezen. In 54 monsters kon geen prolactine worden aangetoond. In 5 monsters werd meer dan $0,05 \mathrm{U} / \mathrm{(}(0,26$ tot $4,09 \mathrm{U} / \mathrm{l})$ prolactine aangetroffen. Bij deze 5 was tevens bloed in het monster aanwezig.

De prolactineconcentratie in cervixslijm

Het bleek uitermate moeilijk om zuiver cervixslijm te verkrijgen. De slijmprop in het cervicale kanaal is dermate taai dat deze moeilijk is te verwijderen. Bovendien is 
diagnostiek

onbekend wat de gevolgen zijn van het artificieel verwijderen van de slijmprop; er werd dan ook genoegen genomen met slijm gelegen buiten de endocervix. In totaal is aldus 15 maal een cervixslijmmonster onderzocht. Negen maal werd geen prolactine gevonden $(<0,002 \mathrm{U} / \mathrm{l})$, zes maal wel. Indien prolactine aantoonbaar was varieerde de concentratie van 0,07 tot $0,91 \mathrm{U} / /$; evenals bij fluor vaginalis bleek bij deze waarden tevens bloed in het monster aanwezig te zijn.

\section{Conclusies}

1. In vaginaal afgelopen vruchtwater varieert de concentratie prolactine sterk. De hoogste waarde wordt tussen de $20^{\circ}$ en $24^{c}$ week aangetroffen. $\mathrm{Na}$ de $24^{\mathrm{c}}$ week daalt de concentratie om van de $28^{\mathrm{e}}$ tot de $42^{\mathrm{e}}$ week een plateauwaarde te bereiken.

2. Prolactine is in het serum aantoonbaar gedurende de gehele zwangerschap. De concentratie stijgt in de loop van de zwangerschap en is gemiddeld de helft van de vruchtwaterconcentratie.

3. In urine kan geen prolactine worden aangetoond.

4. In fluor vaginalis en cervixslijm kan alleen prolactine worden aangetoond als er bloedbijmenging is.

5. In semen is prolactine aantoonbaar.

6. Als de prolactinebepaling wordt gebruikt om de diagnose gebroken vliezen te stellen zal de betrouwbaarheid van deze bepaling negatief worden beïnloed door bloedbijmenging.

\subsubsection{Het vergroten van de betrouwbaarheid van de prolactinebepaling bij dubieus gebroken vliezen}

Indien de gegevens uit de vorige paragraaf worden gebruikt om de diagnose gebroken vliezen aan te tonen of uit te sluiten, dan ligt het voor de hand grote waarde toe te kennen aan eventuele bijmenging van bloed. Wordt dit nagelaten, dan is de conclusie van Huber e.a. (1983) begrijpelijk dat prolactine niet belangrijk bijdraagt aan de diagnostiek van het gebroken zijn van de vliezen.

Wel kunnen bij de door Koninckx e.a. (1981) en Phocas e.a. (1989) gevonden sensitiviteit en specificiteit van $100 \%$ vraagtekens worden gezet daar weinig vruchtwater met veel fluor verdund een nauwelijks meetbare prolactineconcentratie op kan leveren. Omgekeerd kan bloedbijmenging van fluor vaginalis, toch geen uitzon- 
derlijke verloskundige situatie, een zeer goed meetbare prolactineconcentratie geven. Dit probleem wordt versterkt doordat prolactine in het vruchtwater na de $24^{\mathrm{e}}$ week daalt en prolactine in het bloed gedurende de gehele zwangerschap toeneemt. Het verschil wordt zo gering dat bij bloedbijmenging of verdunning van vruchtwater in fluor vaginalis concentraties kunnen worden gemeten die van dezelfde orde van grootte zijn (figuur 16).

Koninckx e.a. (1981) hebben geprobeerd dit probleem op te lossen door de prolactineconcentratie in vaginaal afgelopen vocht te vergelijken met de concentratie van prolactine in bloed. De achterliggende gedachte is: indien de prolactine in de fluor vaginalis van patiënte hoger is dan de serumconcentratie, dan moet er vruchtwaterbijmenging zijn. Er wordt echter voorbijgegaan aan:

1. de mogelijke verdunning van vruchtwater in de vagina

2. de onafhankelijkheid van de prolactineproduktie door de moederlijke hypofyse enerzijds en de produktie door de decidua anderzijds

3. lekkage van prolactine uit de deciduacel naar vaginaal aflopend bloed.

Aanvankelijk bestond twijfel over de onafhankelijkheid van de prolactineproduktie door de moederlijke hypofyse enerzijds en de produktie door de decidua anderzijds. Het is nu echter zo goed als zeker dat de produktie van prolactine door de decidua, de herkomst van "vruchtwaterprolactine", onafhankelijk is van de hypofyse (Biswas 1976, Freeman e.a. 1976, Soria e.a. 1977, Bigazzi e.a. 1979, Riddick e.a. 1979, Markoff e.a. 1983, Kubota e.a. 1986).

Indien de prolactineproduktie "voor" het vruchtwater onafhankelijk is van de produktie "voor" het serum dan zou de prolactineconcentratie van het serum hoger kunnen zijn. In dit onderzoek bleek bij 125 gepaarde waarnemingen 13 maal de serumconcentratie inderdaad hoger dan die in het vruchtwater. Het is derhalve begrijpelijk dat Huber e.a. (1983) de resultaten van Koninckx e.a. (1981) niet kunnen bevestigen. Phocas e.a. (1989) gaan aan het verschijnsel van fout-positieve en fout-negatieve uitslagen zelfs geheel voorbij.

Het ontwikkelen van een methode om de aanwezigheid van "vruchtwaterprolactine" met meer zekerheid te kunnen uitsluiten of aantonen lijkt van belang. Weliswaar is prolactine in bloed niet geheel identiek, qua molecuulstructuur, (Taguchi e.a. 1985) aan prolactine in vruchtwater, maar de beschikbare prolactinebepalingen differentiëren hiertussen niet. Toch leek het mogelijk een verschil te maken tussen prolactine afkomstig van bloed en van vruchtwater. In bloed is de totale hoeveelheid eiwit namelijk hoog en in vruchtwater, fluor vaginalis en cervixslijm laag. Daarom werd in alle monsters, voor zover mogelijk in tweede instantie, tevens de hoeveelheid eiwit bepaald (paragraaf 6.3 ).

De concentratie van prolactine per gram eiwit (U/g.e.) werd verkregen door de concentratie van prolactine (U/l) te delen door de concentratie van eiwit (g.e./I). De resultaten zijn vermeld in tabel 60 . 
Tabel 60: De gemiddelde prolactineconcentratie (gem. conc.) per gram eiwil \pm S.D., in klassen van amenorroe in vruchrwater (vrw.), serum. fluor vaginalis (fluor) en cervixslijm bij patiënten mel een zekere diagnose en het aantal uitgevoerde bepalingen.

\begin{tabular}{|c|c|c|c|c|}
\hline & $\begin{array}{r}\text { gem. vrw.- } \\
\text { conc. } \pm \text { S.D. } \\
(\text { U/g.e. })\end{array}$ & $\begin{array}{l}\text { gem. serum- } \\
\text { conc. } \pm \text { S.D. } \\
\text { (U/g.e.) }\end{array}$ & $\begin{array}{r}\text { gem. fluor- } \\
\text { conc. } \pm \text { S.D. } \\
\text { (U/g.e.) }\end{array}$ & $\begin{array}{l}\text { gem. cervix- } \\
\text { slijmconc. } \pm \\
\text { S.D. (U/g.e) }\end{array}$ \\
\hline \multicolumn{5}{|l|}{$\begin{array}{l}\text { amenorroe } \\
\text { (in weken) }\end{array}$} \\
\hline 16 tot 20 & $7,71 \pm 4,03$ & $0,03 \pm 0,01$ & $0 \pm 0$ & 0 \\
\hline 20 tot 24 & $5,26 \pm 4,09$ & $0,05 \pm 0,04$ & $0 \pm 0$ & - \\
\hline 24 tot 28 & $3.67 \pm 2.47$ & $0.07 \pm 0.04$ & $0 \pm 0$ & - \\
\hline 28 tot 32 & $3,42 \pm 2,23$ & $0,05 \pm 0,02$ & $0 \pm 0$ & 0 \\
\hline $32 \operatorname{tot} 36$ & $4,24 \pm 1,39$ & $0.07 \pm 0.03$ & $0.01 \pm 0.02$ & 0 \\
\hline 36 tot 42 & $5.76 \pm 5,55$ & $0,09 \pm 0,04$ & $0.10 \pm 0.35$ & $0.02 \pm 0.03$ \\
\hline aantal & 129 & 126 & 59 & 15 \\
\hline
\end{tabular}

Uit tabel 60 blijkt dat de gemiddelde waarden van dit quotiënt in de verschillende lichaamsvloeistoffen bij elke amenorroeklasse ver uit elkaar liggen, daar de standaarddeviatie groot is. Tabel 61 geeft een beter inzicht.

Tabel 61: Frequentie verdeling van het quotiënt prolactine/gram eiwit van vruchtwater, serum, urine, fluor vaginalis en cervixslijm en het aantal uitgevoerde bepalingen.

\begin{tabular}{crrrrr}
\hline & $\begin{array}{c}\text { Vrucht- } \\
\text { water }\end{array}$ & Serum & Urine & $\begin{array}{r}\text { Fluor } \\
\text { vaginalis }\end{array}$ & $\begin{array}{r}\text { Cervix- } \\
\text { slijm }\end{array}$ \\
\cline { 2 - 6 } $\begin{array}{c}\text { concentratie } \\
\text { (U/g.e.) }\end{array}$ & & & & & \\
0.0 & 0 & 105 & 72 & 56 & 15 \\
0.1 & 0 & 20 & 0 & 1 & 0 \\
0.2 & 1 & 1 & 0 & 1 & 0 \\
0.3 & 1 & 0 & 0 & 0 & 0 \\
0.4 & 0 & 0 & 0 & 0 & 0 \\
0.5 & 2 & 0 & 0 & 0 & 0 \\
0.6 & 2 & 0 & 0 & 0 & 0 \\
0.7 & 2 & 0 & 0 & 0 & 0 \\
0.8 & 0 & 0 & 0 & 0 & 0 \\
0.9 & 0 & 0 & 0 & 0 & 0 \\
$>1.0$ & 121 & 0 & 0 & 1 & 0 \\
aantal & 129 & 126 & 72 & 59 & 15 \\
\hline
\end{tabular}


hoofdstuk 6

In tabel 61 valt één "uitbijter" direct op: één fluor vaginalis-monster werd gevonden met een quotiënt prolactine/gram eiwit groter dan $1,0 \mathrm{U} / \mathrm{g} . e$. . Bij bestudering van de betreffende ziektegeschiedenis bleek de verklaring voor dit "fenomeen" niet moeilijk te zijn. De onderzoeker die het monster heeft verzameld was ontgaan dat de vliezen reeds waren gebroken. Deze waarde zou dan ook buiten beschouwing kunnen worden gelaten.

Verder valt op dat er maar 4 waarden van dezelfde orde van grootte zijn in vruchtwater serum en fluor vaginalis. Gelet op dit geringe aantal overlappende waarden moet het quotiënt van de concentraties prolactine/gram eiwit een goede test zijn om de diagnose gebroken vliezen te stellen of met zekerheid te kunnen ontkennen.

In het semen van 5 fertiele mannen bleek de eiwitconcentratie vergelijkbaar met de concentratie in serum (laagste concentratie $50,0 \mathrm{~g} / \mathrm{l}$ en de hoogste $56,5 \mathrm{~g} / \mathrm{l}$ ).

Derhalve kan semen geen substantiële bijdrage leveren aan het quotiënt van prolactine/eiwit daar de concentratie van prolactine laag is (variërend van 0,17 tot 0,56 U/l) en de eiwitconcentratie hoog.

Uit tabel 61 blijkt dat het quotiënt van de concentraties prolactine/gram eiwit het best differentieert tussen het staan of gebroken zijn van de vliezen bij een afkappunt tussen 0,1 en 0,2 U/g.e..

\section{Conclusies}

1. Het quotiënt van de concentraties prolactine/eiwit in vaginaal afgelopen vocht is op basis van de waarden, verkregen bij patiënten met een zekere diagnose potentieël, een goed diagnosticum om het staan of het gebroken zijn van de vliezen aan te tonen.

2. Indien de vliezen staan zal zeer zelden meer dan 0,1 tot $0,2 \mathrm{U}$ prolactine per gram eiwit worden gevonden.

\subsubsection{Prolactinebepaling bij patiënten met dubieus gebroken vliezen}

Tabel 62 laat de frequentieverdeling van concentraties prolactine per gram eiwit zien bij patiënten met staande en gebroken vliezen uit de groep met dubieus gebroken vliezen. 
Tabel 62: De frequentieverdeling van gevonden quotiënten prolactine/g.e. in de groep met dubieus gebroken vliezen, verdeeld naar het aamal patiënten waarbij de vliezen stonden of waren gebroken.

\begin{tabular}{|c|c|c|}
\hline & $\begin{array}{r}\text { Uiteindelijke } \\
\text { diagnose } \\
\text { gebroken vliezen }\end{array}$ & $\begin{array}{r}\text { Uiteindelijke } \\
\text { diagnose }\end{array}$ \\
\hline \multicolumn{3}{|l|}{$\begin{array}{r}\text { prolactine- } \\
\text { concentratie } \\
\text { (U/g.e.) }\end{array}$} \\
\hline$<0,1$ & 5 & 54 \\
\hline $\operatorname{van} 0,1$ tot 0,2 & 0 & 2 \\
\hline van 0,2 tot 0.3 & 2 & 3 \\
\hline $\operatorname{van} 0,3$ tot 0,4 & 0 & 1 \\
\hline van 0.4 tot 0,5 & 2 & 0 \\
\hline van 0,5 tot 0.6 & 3 & 0 \\
\hline $\operatorname{van} 0.6$ tot 0.7 & 3 & 0 \\
\hline $\operatorname{van} 0.7$ tot 0.8 & 0 & 0 \\
\hline $\operatorname{van} 0.8$ tot 0.9 & 1 & 0 \\
\hline $\operatorname{van} 0.9$ tot 1.0 & 1 & 0 \\
\hline$\geq 1.0$ & 22 & 1 \\
\hline totaal & 39 & 61 \\
\hline
\end{tabular}

Uit tabel 62 blijkt dat slechts bij 7 patiënten met staande vliezen een meetbare prolactineconcentratie werd gevonden. Het valt op dat er één patiënte is met staande vliezen die in het vaginaal opgevangen vocht een prolactineconcentratie heeft die zeer hoog is: 10,59 U/g.e.. Gezien de referentiewaarden en de andere uitslagen die worden gevonden bij staande vliezen in de dubieus gebroken vliezen groep kan de diagnose "gebroken vliezen" hier niet juist zijn geweest.

Indien wordt aangenomen (zie paragraaf 6.7.4) dat in vaginaal afgelopen vocht met gebroken vliezen meer dan 0,1 U/g.e. prolactine moet voorkomen dan zijn 5 van de 39 uitslagen fout-negatief wat een sensitiviteit oplevert van: $34 / 39=87,2 \%$.

Bij hetzelfde afkappunt zijn in de groep met staande vliezen 7 uitslagen fout-positief hetgeen een specificiteit oplevert van: $54 / 61=88,5 \%$.

De sensitiviteit en specificiteit bij verschillende afkappunten is uitgezet in figuur 17. 
Figuur 17: ROC-curve van het quotiënt prolactinelg.e. bij de afkappunten: van 0 tot 0.8 U/g.e. met intervallen van 0.1 U/g.e..

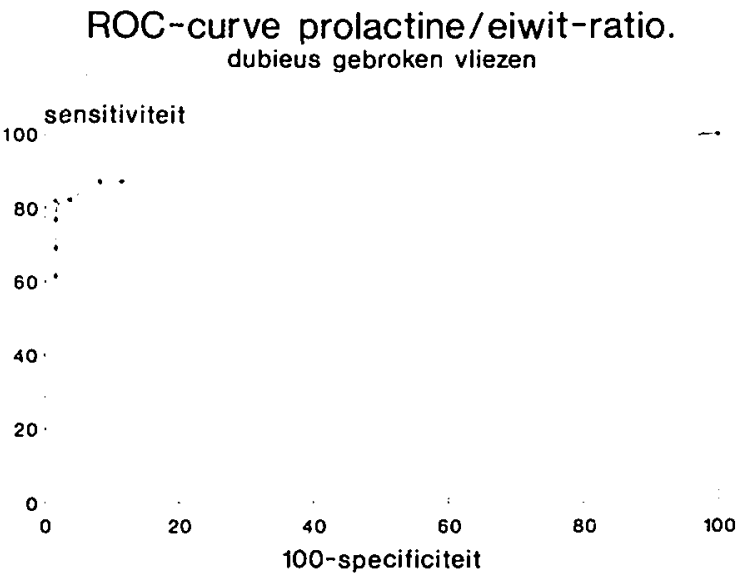

Indien het afkappunt wordt gelegd bij 0,2 U/g.e. dan heeft dit geen effect op de sensitiviteit, terwijl de specificiteit licht verbetert: $87,2 \%$ en $91,8 \%$.

Het afkappunt verhogen naar 0,3 U/g.e. geeft een sensitiviteit van $82,1 \%$ en een specificiteit van $96,7 \%$. Het afkappunt brengen naar $0,4 \mathrm{U} / \mathrm{g}$.e. resulteert in een sensitiviteit en specificiteit van respectievelijk: $82,1 \%$ en $98,4 \%$. Het afkappunt verder verhogen geeft een daling van de sensitiviteit en een specificiteit die gelijk blijft. Gezien deze bevindingen is het meest betrouwbare afkappunt, zoals eerder gedefinieerd (Conell en Koepsell 1985), 0,4 U/g.e.. Klinisch lijkt de hogere sensitiviteit bij het afkappunt $0,2 \mathrm{U} / \mathrm{g}$.e. meer van belang. Dit punt wordt in de verdere berekeningen gehanteerd.

De predictieve waarde van een positieve test (in vaginaal afgelopen vocht wordt tenminste $0,2 \mathrm{U} / \mathrm{g}$.e. prolactine gevonden) bedraagt $87,2 \%$.

De predictieve waarde van een negatieve test (in vaginaal afgelopen vocht wordt minder dan $0,2 \mathrm{U} / \mathrm{g}$.e. prolactine aangetroffen) bedraagt $91,8 \%$.

\section{Conclusies}

1. De sensitiviteit van de prolactinebepaling bij dubieus gebroken vliezen bij het optimale afkappunt van $0,2 \mathrm{U} / \mathrm{g}$.e. is $87,2 \%$, de specificiteit $91,8 \%$.

2. De predictieve waarde van een positieve test bij dit afkappunt is $87,2 \%$, van een negatieve test $91,8 \%$. 


\section{- Resultaten van het onderzoek}

\subsection{Kreatininebepaling}

\subsubsection{Inleiding}

Daar in urine hoge concentraties kreatinine aanwezig zijn, lijkt het eenvoudig om bijmenging van urine in vaginaal afgelopen vocht aan te tonen. Merkwaardigerwijs wordt de bepaling van kreatinine door geen enkele auteur genoemd in overzichtsartikelen waarin de diagnostiek van gebroken vliezen wordt samengevat (Lange Friedman en McElin 1969, Gunn e.a. 1970, Smith 1976). Toch wordt deze bepaling wel gebruikt in Nederland, getuige bijvoorbeeld de handleiding "Klinische Obstetrie" van het Academisch Ziekenhuis te Groningen.

Dit was voldoende reden om de kreatininebepaling als diagnostische mogelijkheid te bezien bij dubieus gebroken vliezen.

\subsubsection{Bepalingsmethode van kreatinine}

Bij de kreatininebepaling wordt gebruik gemaakt van de Jaffé-reactie. Deze reactie gaat uit van het principe dat kreatinine met picrinezuur, in een alkalisch milieu, een geel/rood gekleurd complex vormt. De verandering van absorptie, tussen de $20^{\circ}$ en $80^{c}$ seconde na de samenvoeging, is een maat voor de concentratie.

Gebruikt werden oplossingen van Roche Diagnostica (List no. 0714216) en de bepalingen werden uitgevoerd in een Cobas Bio-systeem.

\subsubsection{Kreatininebepaling bij patiënten met een zekere diagnose}

De bepaling van kreatinine in vruchtwater, serum, urine en semen

In de vloeistoffen die werden verzameld bij patiënten met een zekere diagnose, zoals beschreven in paragraaf 6.2 , werd het kreatinine bepaald. Het aantal bepalingen dat per amenorroeklasse per vocht is uitgevoerd is vermeld in tabel 63 en tabel 66. De gemiddelde kreatininewaarden in de verschillende amenorroeklassen met de bijbehorende standaarddeviatie voor vruchtwater, serum en urine zijn weergegeven in tabel 63. 
hoofdstuk 6

Tabel 63: De gemiddelde kreatinineconcentraties (gem. kreat. conc.) $\pm S . D$. per amenorroeklasse in vruchtwater $(v r w)$, serum, en urine bij patiënten met een zekere diagnose en het aantal uitgevoerde bepalingen.

gem. kreat. conc. vrw \pm S.D. $(\mu \mathrm{mol} / \mathrm{l})$ gem. kreat. conc. serum \pm

S.D. $(\mu \mathrm{mol} / \mathrm{l})$ gem. kreat. conc. urine \pm S.D. $(\mathrm{mmol} / \mathrm{l})$

amenorroe

(weken)

16 10t 20

20 tot 24

24 tot 28

28 tot 32

32 tot 36

36 tot 42

aantal

$\begin{array}{rr}54,8 \pm & 8,8 \\ 83,8 & \pm 32,9 \\ 267.2 & \pm 659,0 \\ 102,5 & \pm 24,3 \\ 459,7 & \pm 1397.6 \\ 200.9 & \pm 183,9\end{array}$

140
$54,5 \pm 5,6$

$54,1 \pm 6,0$

$60,4 \pm 12,6$

$57.9 \pm 6.8$

$54.7 \pm 8.0$

$59,1 \pm 10,9$
$10,5 \pm 5,1$

$7.5 \pm 4.9$

$10.3 \pm 8.1$

$8,8 \pm 4,7$

$9,7 \pm 6,2$

$8,7 \pm 5,8$

198

In tabel 63 is te zien dat de kreatinineconcentratie in urine, zoals verwacht, hoog is en in serum en vruchtwater laag. Deze lage concentratie in vruchtwater maakt het op voorhand geen ideale methode voor de diagnostiek van gebroken vliezen. Toch is onderzocht of de kreatinineconcentratie bij dubieus gebroken vliezen is te gebruiken om gebroken vliezen aan te tonen. Er zijn namelijk geen literatuurgegevens voorhanden betreffende de aanwezigheid van kreatinine in fluor vaginalis en cervixslijm.

In tabel 63 is te zien dat in serum en urine, onafhankelijk van de amenorroeduur, een redelijk constante kreatinine-concentratie voorkomt met een relatief kleine standaarddeviatie. Dit is niet het geval bij kreatinine in vruchtwater. Wel bleek dat in de groepen met een grote standaarddeviatie (zoals in de klassen van 24 tot 28 weken, 32 tot 36 weken en 36 tot 42 weken) één sterk afwijkende uitslag aanwezig was. Bij bestudering van de klinische gegevens van de uitbijter in de verschillende amenorroeklassen werd geen verklaring gevonden voor de afwijkende waarde. In de literatuur worden bij normale en gecompliceerde zwangerschappen dergelijke hoge waarden $(>1500 \mu \mathrm{mol} / \mathrm{l})$ niet beschreven (Pitkin en Zwirek 1967, Roopnarinesingh 1970 en 1973, Harrison 1973 , v. Geuns en v. Kessel 1978). De verhoogde waarden moeten worden toegeschreven aan "verontreiniging" met urine. Als deze drie afwijkende waarden worden weggelaten komen de kreatinineconcentraties in vruchtwater geheel overeen met die welke in de literatuur worden vermeld (Pitkin en Zwirek 1967, Roopnarinesingh 1970 en 1973, Harrison 1973, Josimovich 1978). De gemiddelde aldus "gecorrigeerde" vruchtwater-kreatinine-waarden bij de amenorroeklassen zijn vermeld in tabel 64. 
Tabel 64: De gemiddelde "gecorrigeerde" kreatinineconcentratie in vruchtwater (gem. conc. kreat. vrw.). gemiddelde kreatinineconcentratie in serum (gem. conc. kreat. serum) en de gemiddelde kreatinineconcentratie in urine (gem. kreat. conc. urine) \pm S.D. per amenorroeklasse bij patiënten met een zekere diagnose en het aantal uitgevoerde bepalingen.

\begin{tabular}{|c|c|c|c|}
\hline & $\begin{array}{r}\text { gem. conc. } \\
\text { kreat. vrw. } \pm \\
\text { S.D. }(\mu \mathrm{mol} / /)\end{array}$ & $\begin{array}{r}\text { gem. conc. } \\
\text { kreat. serum } \pm \\
\text { S.D. }(\mu \mathrm{mol} / /)\end{array}$ & $\begin{array}{l}\text { gem. conc. } \\
\text { kreat. urine } \pm \\
\text { S.D. (mmol//) }\end{array}$ \\
\hline \multicolumn{4}{|l|}{$\begin{array}{r}\text { amenorroe } \\
\text { (weken) }\end{array}$} \\
\hline $\begin{array}{l}16 \text { tot } 20 \\
20 \text { tot } 24 \\
24 \text { tot } 28 \\
28 \text { tot } 32 \\
32 \text { tot } 36 \\
36 \text { tot } 42\end{array}$ & $\begin{array}{r}54,8 \pm 8,8 \\
83,8 \pm 32,9 \\
77,0 \pm 8,1 \\
102,5 \pm 24,3 \\
147,7 \pm 81,1 \\
173,0 \pm 42,0\end{array}$ & $\begin{array}{lr}54,5 \pm & 5,6 \\
54,1 \pm & 6,0 \\
60,4 \pm & 12,6 \\
57,9 \pm & 6,8 \\
54,7 \pm & 8,0 \\
59,1 \pm & 10,9\end{array}$ & $\begin{array}{r}10,5 \pm 5,1 \\
7,5 \pm 4,9 \\
10,3 \pm 8,1 \\
8,8 \pm 4,7 \\
9,7 \pm 6,2 \\
8,7 \pm 5,8\end{array}$ \\
\hline aantal & 137 & 198 & 193 \\
\hline
\end{tabular}

Uit tabel 64 blijkt, zoals uit de literatuur bekend was, dat de gemiddelde kreatinineconcentratie in het vruchtwater stijgt met het vorderen van de zwangerschap.

Uit tabel 64 blijkt eveneens dat bij een amenorroe van minder dan 28 weken de kreatinineconcentratie van serum met de kreatinineconcentraties in vruchtwater overeenkomt. Na de $28^{c}$ week stijgt de kreatinineconcentratie in vruchtwater en is hoger dan die in het serum.

De gemiddelde kreatinineconcentratie van semen, gemeten in 5 monsters van fertiele mannen, bedroeg $291 \mu \mathrm{mol} / \mathrm{l}$. De laagste waarde was $166 \mu \mathrm{mol} / \mathrm{l}$, de hoogste 432 $\mu \mathrm{mol} / \mathrm{l}$. De kreatinineconcentratie in semen is derhalve hoog ten opzichte van de concentratie van kreatinine in vruchtwater.

Kreatinine in fluor vaginalis en cervixslijm kan niet direct worden bepaald. Beide substanties zijn te viskeus en eerst moet extractie plaats vinden (paragraaf 6.3). Omdat bij extracties de concentratie wordt berekend per gram aanwezig eiwit zijn de eiwitconcentraties van alle lichaamsvloeistoffen die zijn verzameld van belang. De gemiddelde eiwitconcentraties \pm S.D. per amenorroeklasse zijn reeds vermeld in paragraaf 6.3.1. 
hoofdstuk 6

De kreatinineconcentraties van vruchtwater en serum per gram eiwit zijn weergegeven in tabel 65 .

Tabel 65: De gemiddelde kreatinineleiwit-ratio (gem. kreat. conc.) \pm S.D. in vruchtwater (vrw.) en serum (in umollgram eiwit) per amenorroeklasse en het aantal bepalingen dal werd uitgevoerd.

gem. kreat. conc. vrw.

\pm S.D. $(\mu \mathrm{mol} / \mathrm{g} . \mathrm{e}$. gem. kreat. conc. serum \pm S.D. ( $\mu \mathrm{mol} / \mathrm{g} . \mathrm{e}$.

$\begin{array}{rrr}\begin{array}{r}\text { amenorroe } \\ \text { (weken) }\end{array} & \\ 16 \text { tot } 20 & 10,4 \pm 5,4 & 0,9 \pm 0.1 \\ 20 \text { tot } 24 & 19.6 \pm 22,2 & 0,8 \pm 0.1 \\ 24 \text { tot } 28 & 3,1 \pm 9,7 & 1,0 \pm 0,3 \\ 28 \text { tot } 32 & 24,5 \pm 16,4 & 1,0 \pm 0,1 \\ 32 \text { tot } 36 & 45,5 \pm 33,7 & 1,0 \pm 0,2 \\ 36 \text { tot } 42 & 68,6 \pm 31,0 & 1,1 \pm 0.2 \\ \text { aantal } & 129 & 126\end{array}$

De gemiddelde kreatinine/eiwit-ratio in vruchtwater neemt toe met de amenorroeduur. Zoals te zien is in tabel 65 is de gemiddelde kreatinine/eiwit-ratio van serum laag. Bloedbijmenging zal derhalve geen bijdrage van betekenis leveren aan kreatinine/per gram eiwit in vaginaal afgelopen vocht.

De gemiddelde eiwitconcentratie in semen was in de 5 monsters van fertiele mannen: $53,6 \mathrm{~g} /$. Bijmenging van semen $\mathrm{zal}$ een lage kreatinine/eiwit-ratio veroorzaken in vaginaal afgelopen vocht.

De kreatinineconcentratie in fluor vaginalis en cervixslijm

De gemiddelde kreatinineconcentraties (in $\mu \mathrm{mol} / \mathrm{gram}$ eiwit) en de standaarddeviatie in de amenorroeklassen staan vermeld in tabel 66. 
Tabel 66: De gemiddelde kreatinineleiwit-ratio (gem. kreat. conc.) \pm S.D. in fluor vaginalis en cervixslijm (umollgram eiwit) per amenorroeklasse en het aantal bepalingen dat werd uitgevoerd.

gem. kreat. conc. in fluor vaginalis \pm S.D. $(\mu \mathrm{mol} / \mathrm{g}$. e. $)$ gem. kreat. conc. in cervixslijm \pm S.D. $(\mu \mathrm{mol} / \mathrm{g} . \mathrm{e}$.

amenorroe

(weken)

16 tot 20

20 tot 24

24 tot 28

28 tot 32

32 tot 36

36 tot 42

aantal
$36,3 \pm 39,5$

$21,3 \pm 8,2$

$23,8 \pm 10,9$

$28,2 \pm 26,1$

$49,7 \pm 50,8$

$10,8 \pm 7,1$
$3.6 \pm$ -

- \pm -

- \pm -

$8.9 \pm-$

$5.9 \pm-$

$6,7 \pm 3,9$

Uit tabel 65 en tabel 66 blijkt dat de kreatinineconcentratie per gram eiwit in fluor vaginalis en die in vruchtwater van dezelfde orde van grootte zijn. De kreatininebepaling zal dan ook waarschijnlijk geen bijdrage kunnen leveren aan de diagnostiek bij dubieus gebroken vliezen.

\section{Conclusie}

De kreatininebepaling in vaginaal vocht lijkt alleen geschikt om urine aan te tonen.

\subsubsection{Kreatininebepaling bij patiënten met dubieus gebroken vliezen}

Bij de 100 patiënten met dubieus gebroken vliezen, zoals beschreven in paragraaf 6.2 , werd de kreatinineconcentratie per gram eiwit gebruikt als mogelijk diagnosticum om het staan of het gebroken zijn van de vliezen aan te tonen. Zoals uit bepalingen bij patiënten met een zekere diagnose duidelijk is geworden overlappen de concentratie van kreatinine in vruchtwater en fluor vaginalis elkaar.

$\mathrm{Bij}$ verschillende afkappunten werd de sensitiviteit en specificiteit berekend. De waarden zijn weergegeven in figuur 18: de ROC-curve. 
hoofdstuk 6

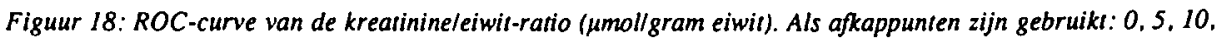
20,40 en 50 mollg.e; als bovengrens werd steeds 1000 molll gehanteerd.

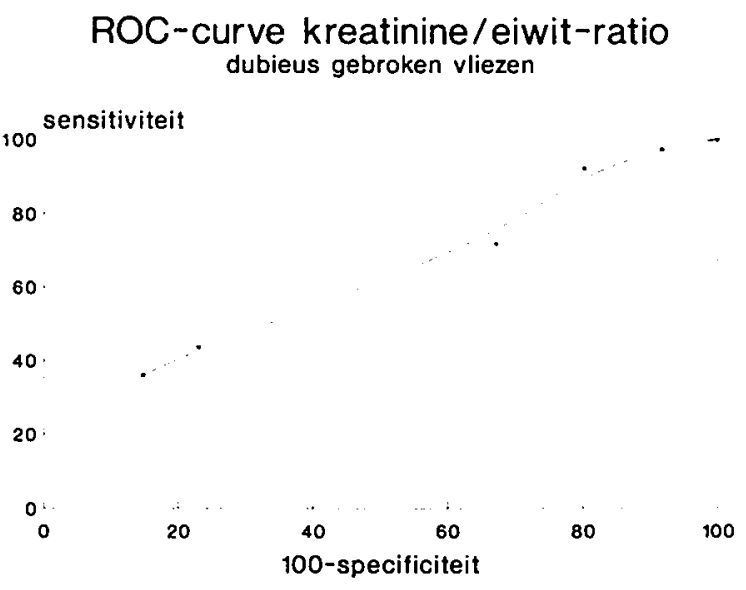

Uit de ROC-curve kan worden bevestigd wat op basis van de bepaling van de kreatinine/eiwit-ratio bij patiënten met een zekere diagnose werd verwacht, namelijk dat de kreatinine-bepaling een verre van ideale test is om te gebruiken bij dubieus gebroken vliezen.

\section{Conclusie}

De kreatininebepaling heeft geen betekenis bij de diagnostiek van dubieus gebroken vliezen. 


\section{- Resultaten van het onderzoek}

\subsection{Diamine-oxidase-activiteit}

\subsubsection{Inleiding}

Diamine-oxidase (DAO: EC 1.4.3.6.) is een enzym dat oxydatie van diamines, zoals histamine, putrescine (1,4-diaminobutaan) en cadaverine (1,5-diaminopentaan) katalyseert. Er wordt bij dit proces een aminoaldehyde gevormd. Het diamine-oxidase (DAO) wordt zeker voor een deel geproduceerd door de decidua (Wishart e.a. 1979). De betekenis van het enzym in de placenta zou zijn, te voorkomen dat diamines in de maternale circulatie terecht komen. Het enzym werkt als een soort "barrière".

Het enzym is in het plasma van zowel zwangeren als niet-zwangeren aanwezig. De concentratie neemt tijdens de zwangerschap toe (Kusche en Lorenz 1986). Het komt in vruchtwater ook voor en de concentratie is in het algemeen lager dan die in plasma van de moeder (Kusche en Lorenz 1986). Volgens dezelfde auteurs stijgt de concentratie van het enzym in het serum van de zwangere vrouw aan het begin van de zwangerschap en bereikt een plateau-waarde tussen de $6^{\mathrm{c}}$ tot $12^{\mathrm{c}}$ week van de zwangerschap. Enige dagen post partum daalt de concentratie van het enzym snel tot zeer lage waarden.

De toename van de DAO-activiteit tijdens de zwangerschap wordt waarschijnlijk veroorzaakt door lysis van de decidua-cellen. Secretie is evenwel niet uitgesloten.

Bij complicaties in de zwangerschap, zoals een dreigende miskraam, hyperemesis gravidarum en toxicose, daalt de DAO-activiteit in het bloed (Kusche en Lorenz 1986). De concentratie, van onder meer histamine, in het bloed van de moeder stijgt hierdoor. De DAO-activiteit kan ook gebruikt worden om placentaresten die nog actief zijn in utero aan te tonen en de DAO-bepaling kan gebruikt worden om na evacuatie van een mola hydatidosa te controleren of de verwijdering compleet is geweest dan wel om een recidief aan te tonen (Kusche en Lorenz 1986).

Kusche en Lorenz (1986) geven aan dat de DAO-activiteit ook kan worden gebruikt als "tumor marker" bij maligne processen van de uterus en de ovaria: corpuscarcinoom, myosarcoom en granulosacel-tumoren. Verder is van belang dat heparine, intraveneus toegediend, een aanzienlijke stijging geeft van de DAO-activiteit, ook bij niet zwangere patiënten.

De DAO-activiteitsbepaling als diagnosticum om vruchtwaterverlies aan te tonen werd voor het eerst beschreven in 1974 (Elmfors e.a.). In tabel 67 zijn de literatuurgegevens betreffende de betrouwbaarheid van de DAO-activiteit bij een zekere diagnose samengevat. 
hoofdstuk 6

Tabel 67: Lileratuuroverzicht van de DAO-bepaling bij een zekere diagnose.

\begin{tabular}{rrrrr}
\hline & $\begin{array}{r}\text { jaar } \\
\text { patienten }\end{array}$ & aantal & $\begin{array}{r}\text { sensitivi- } \\
\text { teit (\%) }\end{array}$ & $\begin{array}{r}\text { specifici- } \\
\text { teit (\%) }\end{array}$ \\
\cline { 2 - 5 } auteur & & & & \\
Elmfors e.a. & 1974 & 200 & 100 & 100 \\
Schumacher e.a. & 1976 & 131 & 97 & 87 \\
Wishart e.a. & 1979 & 146 & 100 & 100 \\
Gahl e.a. & 1982 & 287 & 98 & 99 \\
Vige e.a. & 1984 & 89 & 93 & 92 \\
\hline
\end{tabular}

Gezien deze resultaten lijken de sensitiviteit en specificiteit zoals weergegeven in tabel 67 aan te geven dat het een uiterst betrouwbare test betreft. Echter bij dubieus gebroken vliezen zou de betrouwbaarheid wel eens minder kunnen zijn. De scepsis berust op de volgende feiten:

- de DAO-activiteit in het bloed van de zwangere is hoger dan die in het vruchtwater (Kusche en Lorenz 1986),

- urine-bijmenging stoort de bepaling van de activiteit (Gahl e.a. 1982).

- semen vertoont DAO-activiteit (Gahl e.a. 1982).

\subsubsection{Bepalingsmethode van DAO-activiteit}

Verschillende methoden zijn beschreven om diamine-oxidase aan te tonen:

- spectrofotometrische

- radiometrische

- radioimmunoassay

- chromatografische.

Daar de radiometrische methode, beschreven door Okuyama en Kobayashi (1961) en Kusche en Lorenz (1986), relatief eenvoudig is werd voor deze methode gekozen. In tegenstelling tot de door deze onderzoekers beschreven methode werd gebruik gemaakt van tritium gelabeld 1,4-diaminobutaan als substraat in de assay (Bank e.a. 1990). Door incubatie van diamine-oxidase met putrescine werd door oxydatieve desaminering van putrescine, gamma-aminobuteraldehyde verkregen. Deze component wordt omgezet tot delta-1-pyrroline door spontane niet-enzymatische cyclisatie. Het radioactieve substraat en zijn produkten worden gescheiden door extractie met tolueen. 
De radioactiviteit van de organische fase is een maat voor de DAO-activiteit. De enzym-activiteit wordt uitgedrukt in Internationale Units (IU).

Eén eenheid (IU) resulteert in het uiteenvallen van $1 \mu \mathrm{mol}$ substraat per minuut onder optimale condities (temperatuur 37 graden Celsius en $\mathrm{pH}=7,4$ ).

De hele procedure is uitvoerig beschreven door Bank e.a. (1990).

Het is van belang dat een remming van de DAO-activiteit is te verwachten door urine, meconium en jodium (Gahl 1982). Ook in dit onderzoek bleek dat, na toevoeging van urine aan vruchtwater, een lagere DAO-activiteit werd gemeten.

\subsubsection{DAO-activiteit bij patiënten met een zekere diagnose}

Zoals beschreven in paragraaf 6.2 werd bij patiënten, met zeker staande of zeker gebroken vliezen, vocht verzameld. Het aantal bepalingen van diamine-oxidase dat in de verschillende lichaamsvloeistoffen werd uitgevoerd is weergegeven in tabel 68 en tabel 70.

In urine zijn enkele bepalingen uitgevoerd, maar geen activiteit werd aangetoond. De gemiddelde DAO-activiteit \pm de standaarddeviatie in vruchtwater en serum in de verschillende amenorroeklassen en het aantal bepalingen is weergegeven in tabel 68 .

Tabel 68: De gemiddelde diamine-oxidase(gem. DAO)-activiteit $\pm S . D$. in de verschillende amenorroeklassen in vruchtwater (vrw.) en serum bij patiënten met een zekere diagnose en het aantal uitgevoerde bepalingen.

gem. DAO-activiteit in vrw. \pm S.D. (U/l) gem. DAO-activiteit

in serum \pm S.D. (U/ ) amenorroe

(weken)

16 tot 20

20 tot 24

24 tot 28

28 tot 32

32 tot 36

36 tot 42

aantal
$0,27 \pm 0,21$
$2,32 \pm 4,62$
$1,45 \pm 1,30$
$0,85 \pm 0,54$
$0,72 \pm 0,76$
$0,67 \pm 0,80$

146

$$
\begin{aligned}
& 0,39 \pm 0,24 \\
& 0,64 \pm 0,28 \\
& 0,70 \pm 0,39 \\
& 0,76 \pm 0,40 \\
& 0,67 \pm 0,36 \\
& 0,90 \pm 1,07
\end{aligned}
$$

201

Tabel 68 laat zien dat in de amenorroeklasse van 16 tot 20 weken een activiteit van diamine-oxidase wordt gemeten die beduidend lager is dan na de $20^{\circ}$ week (dit in 
tegenstelling tot de conclusie van Kusche en Lorenz (1986): hoogste waarde van DAO-activiteit in vruchtwater tussen de $6^{\circ}$ en $12^{\circ}$ week van de zwangerschap). Mogelijk is dit verschil te verklaren door de aangepaste bepalingsmethode.

Tussen de $20^{\circ}$ en $28^{\circ}$ week van de zwangerschap wordt, in dit onderzoek, een zeer verschillende activiteit van het enzym diamine-oxidase in vruchtwater gemeten. De gemiddelde DAO-activiteit in vruchtwater in de amenorroegroep van 20 tot 24 weken wordt sterk beïnvloed door én patiënte waarbij een DAO-activiteit werd vastgesteld van 15,3 U/l. De gemiddelde waarde van DAO in deze amenorroegroep na weglaten van deze uitbijter is: $0,56 \pm 0,70 \mathrm{U} / \mathrm{l}$.

In de amenorroegroep van 24 tot 28 weken werd 4 maal een waarde in vruchtwater van rond de $3 \mathrm{U} / \mathrm{h}$ gemeten, ook dit zijn hoge waarden. Eerst na de $28^{\mathrm{e}}$ week werd een relatief constante waarde van de DAO-activiteit in vruchtwater gemeten.

Geconcludeerd moet worden dat de hoogste waarde van de DAO-activiteit in vruchtwater in dit onderzoek wordt gevonden bij een amenorroe van 24 tot 28 weken. $\mathrm{Na}$ de $28^{c}$ week van de zwangerschap neemt de DAO-activiteit in vruchtwater af.

Een verklaring hiervoor kan worden gevonden in het gegeven dat vaginaal afgelopen vruchtwater is onderzocht bij een patiëntenpopulatie waarbij de zwangerschap gecompliceerd verliep (partus immaturus).

Andere mogelijke oorzaken voor een incidenteel verhoogde DAO-activiteit zijn:

- heparinegebruik

- de aanwezigheid van een partiële mola hydatidosa

- een bronchuscarcinoom bij de moeder

- maligniteiten van uterus of ovaria.

Bij het kind wordt een verhoogde diamine-oxidase-activiteit in het serum in verband gebracht met mucoviscoidosis.

Uiteraard werden de klinische gegevens van moeder en kind bestudeerd; geen van de genoemde afwijkingen werd gevonden en de verhoogde waarden zijn onverklaard gebleven.

Met de Student t-toets voor gepaarde waarnemingen wordt geen significant verschil gevonden tussen de vruchtwater- en serum-DAO-activiteit. De tekentoets levert bij 140 gepaarde waarnemingen als resultaat: 87 maal is de activiteit in het serum hoger, 53 maal in het vruchtwater. De serumwaarden zijn significant hoger $(p=0,01)$ dan de vruchtwaterwaarden. Daar in fluor vaginalis en cervixslijm niet direct bepalingen kunnen worden uitgevoerd werd eerst een extractie verricht en dient de DAO-activiteit in Units per gram eiwit te worden uitgedrukt. De gemiddelde eiwitconcentraties zijn weergegeven in paragraaf 6.3.

De DAO-activiteit per gram eiwit per amenorroeklasse is weergegeven in tabel 69 voor vruchtwater en serum. 
Tabel 69: De gemiddelde DAO-activiteit (gem. DAO-act.) per gram eiwit $\pm S . D$. in vruchtwater (vrw.) en serum in de amenorroeklassen en hel aantal uitgevoerde bepalingen.

$\begin{array}{rrr} & \begin{array}{r}\text { gem. DAO-act. } \\ \text { in vrw. } \pm \text { S.D. } \\ \text { U/.g.e. }\end{array} & \begin{array}{r}\text { gem. DAO-act. } \\ \text { in senum } \pm \text { S.D. } \\ \text { U/g.e. }\end{array} \\ \begin{array}{r}\text { amenorroe } \\ \text { (weken) }\end{array} & \\ & & \\ 16 \text { tot } 20 & 0.039 \pm 0,015 & 0,007 \pm 0,004 \\ 20 \text { tot } 24 & 0,362 \pm 0,283 & 0,010 \pm 0,004 \\ 24 \text { tot } 28 & 0,204 \pm 0,181 & 0,010 \pm 0,005 \\ 28 \text { tot } 32 & 0,209 \pm 0,139 & 0,012 \pm 0,007 \\ 32 \text { tot } 36 & 0,189 \pm 0,183 & 0,012 \pm 0.008 \\ 36 \text { tot } 42 & 0,218 \pm 0,252 & 0,018 \pm 0,029 \\ & & \\ \text { aantal } & 129 & 126\end{array}$

Uit tabel 69 blijkt dat de gemiddelde activiteit van DAO per gram eiwit in vruchtwater steeds hoger is dan die in het serum.

De gemiddelde DAO-activiteit per gram eiwit bij patiënten met een zekere diagnose zijn in fluor vaginalis en cervixslijm berekend in het extract (tabel 70). De methode van extraheren is beschreven in paragraaf 6.3.

Tabel 70: De gemiddelde activiteit van DAO (gem. DAO-act.) per gram eiwit \pm S.D. in fluor vaginalis en cervixslijm in de groep met zeker staande vliezen in de verschillende amenorroeklassen en het aantal bepalingen.

\begin{tabular}{|c|c|c|}
\hline & $\begin{array}{r}\text { gem. DAO-act. in } \\
\text { fluor vaginalis } \\
\pm \text { S.D. (U/g.e.) }\end{array}$ & $\begin{array}{r}\text { gem. DAO-act. in } \\
\text { cervixslijm } \\
\pm \text { S.D. (U/g.e.) }\end{array}$ \\
\hline \multicolumn{3}{|l|}{$\begin{array}{r}\text { amenorroe } \\
\text { (weken) }\end{array}$} \\
\hline 16 tot 20 & $0,11 \pm 0,31$ & $0,0 \pm$ \\
\hline 20 tot 24 & $0.0 \pm 0.0$ & . \pm \\
\hline 24 tot 28 & $0,0 \pm 0,0$ & - \pm- \\
\hline 28 tot 32 & $0,0 \pm 0,0$ & $0,0 \pm$ \\
\hline 32 tot 36 & $0,01 \pm 0,05$ & $0,0 \pm$ \\
\hline 36 tot 42 & $0,02 \pm 0,05$ & $0,01 \pm 0,03$ \\
\hline Aantal & 58 & 15 \\
\hline
\end{tabular}

Slechts één bepaling van diamine-oxidase in fluor vaginalis, in de amenorroegroep van 16 tot 20 weken, laat detecteerbare DAO-activiteit zien (1 U/g.e.). Dit is opmerkelijk daar deze waarde zeker niet wordt verklaard door bloedbijmenging: de eiwit- 
hoofdstuk 6

concentratie was laag en bij deze patiënte was de activiteit in het bloed $0,11 \mathrm{U} / \mathrm{g} . \mathrm{e} . . \mathrm{Bij}$ nadere bestudering van de ziektegeschiedenis werd geen verklaring gevonden voor deze afwijkende waarde.

In cervixslijm wordt steeds een lage activiteit van het enzym diamine-oxidase gevonden.

Ook semen bevat diamine-oxidase. Daar de eiwitconcentratie in semen hoog is zal semen geen substantiële bijdrage leveren aan de DAO-activiteit per gram eiwit in vaginaal afgelopen vocht bij twijfel aan het gebroken zijn van de vliezen.

Gezien de resultaten, met een vruchtwater-DAO-activiteit die ligt tussen de 0 en 1 U/g.e. en het gegeven dat in fluor vaginalis en cervixslijm meestal geen DAO-activiteit wordt waargenomen, werd in eerste instantie 0 als afkappunt genomen.

Er zijn 6 waarnemingen in het vruchtwater die geen diamine-oxidase-activiteit te zien geven. De sensitiviteit is bij dit afkappunt: $140 / 146=95,9 \%$. Indien de bepalingen in fluor vaginalis en cervixslijm als één groep worden beschouwd (de groep met staande vliezen), dan is de specificiteit te berekenen (in fluor vaginalis 6 maal diamine-oxidaseactiviteit groter dan nul en bij cervixslijm 5 maal diamine-oxidase-activiteit groter dan nul): $62 / 73=84,9 \%$. Bij deze percentages moet worden bedacht dat bloedbijmenging eigenlijk altijd een fout positieve uitslag geeft.

Met 0,05 U/g.e. als afkappunt is de sensitiviteit $95,2 \%$ en de specificiteit $94,5 \%$. Indien een afkappunt wordt gekozen dat groter is dan 0,05 U/g.e. heeft dit geen verbetering tot gevolg.

\section{Conclusies}

1. Diamine-oxidase komt voor in vruchtwater.

2. Diamine-oxidase-activiteit is in het bloed van de zwangere vrouw significant hoger dan in het vruchtwater.

3. Aanwezigheid van urine remt de bepaling van diamine-oxidase.

4. In fluor vaginalis en cervixslijm wordt een minimale activiteit van diamine-oxidase gevonden.

5. Semen heeft diamine-oxidase-activiteit.

6. Bij een zekere diagnose ligt het afkappunt dat de hoogste sensitiviteit en specificiteit oplevert bij 0,05 U/g.e.. 
diagnostiek

\subsubsection{DAO-activiteit bij patiënten met dubieus gebroken vliezen}

Tabel 71 laat de frequentieverdeling van de DAO-activiteit zien van de patiëntengroep met dubieus gebroken, vliezen verdeeld naar staande dan wel gebroken vliezen.

Tabel 71: De frequentieverdeling van de ratio DAO-activiteit per gram eiwit in de groep met dubieus gebroken vliezen in vaginaal afgelopen vocht verdeeld naar het aantal patiënten waarbij de vliezen waren gebroken of stonden.

\begin{tabular}{rrr} 
& $\begin{array}{r}\text { uiteindelijke diagnose } \\
\text { gebroken vliezen } \\
n=39\end{array}$ & $\begin{array}{r}\text { uiteindelijke diagnose } \\
\text { staande vliezen } \\
n=61\end{array}$ \\
\cline { 2 - 3 } & & \\
DAO-activiteit & & \\
gram eiwit & & \\
(U/g.e.) & 10 & 47 \\
0 & 8 & 10 \\
0,05 & 5 & 2 \\
0,10 & 4 & 0 \\
0,15 & 5 & 1 \\
0.20 & 3 & 0 \\
0,25 & 1 & 0 \\
0.30 & 1 & 0 \\
0.35 & 0 & 0 \\
0,40 & 0 & 0 \\
0.45 & 0 & 1 \\
0.50 & 2 & \\
$>0,50$ & & \\
& & \\
\hline
\end{tabular}

Uit tabel 71 blijkt dat de DAO-activiteit per gram eiwit in vaginaal afgelopen vocht in de groep met gebroken vliezen en de groep met staande vliezen elkaar overlappen.

Op theoretische gronden (paragraaf 6.9.3) zou een afkappunt van 0,05 U/g.e." ideaal" moeten zijn. Bij bewerking van de resultaten van de groep met dubieus gebroken vliezen blijkt evenwel dat het afkappunt: 0 betere resultaten geeft. De sensitiviteit is dan $74,4 \%$ en de specificiteit $77,0 \%$.

Figuur 19 geeft de sensitiviteit en specificiteit weer bij de verschillende afkappunten. 
hoofdstuk 6

Figuur 19: ROC-curve van de diamine-oxidase-activiteit per gram eiwit. De afkappunten zijn: 0, 0,05, 0,1.0.2. 0.3 en 0.4 U/g.e.

\section{ROC-curve DAO/eiwit-ratio}

dubieus gebroken vliezen
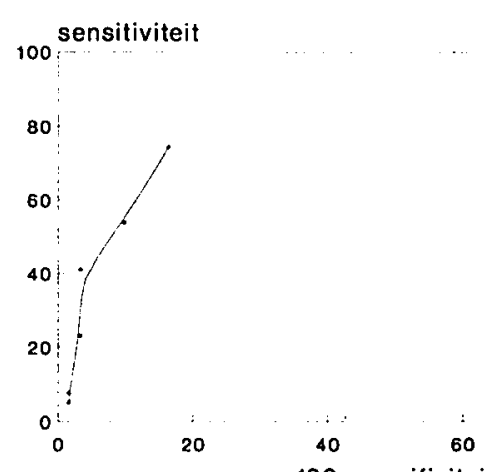

100-specificiteit

Figuur 19 laat zien dat de DAO-activiteit een zeer hoge specificiteit kent ten aanzien van gebroken vliezen maar helaas een lage sensitiviteit.

De voorspellende waarde van een positieve test bij een afkappunt 0 is: $67,4 \%$ en de voorspellende waarde van een negatieve test is dan: $82,5 \%$.

\section{Conclusie}

De sensitiviteit van de DAO-activiteit per gram eiwit bij dubieus gebroken vliezen is bij een afkappunt van $0 \mathrm{U} / \mathrm{g}$.e. $74,4 \%$ en de specificiteit $83,6 \%$. De voorspellende waarde van een positieve test is dan $67,4 \%$ en de voorspellende waarde van een negatieve test $82,5 \%$. De meer positieve literatuurgegevens worden hiermee niet bevestigd. 


\section{- Resultaten van het onderzoek}

\section{$6.10 \alpha$-Foetoproteïne-bepaling}

\subsubsection{Inleiding}

Het $\alpha$-foetoproteïne (AFP) werd ontdekt in 1956 (Bergstrand en Czar 1956) in het serum van immatuur geboren kinderen. AFP is een eiwit dat voornamelijk wordt geproduceerd door de foetale lever. Ook wordt AFP geproduceerd door de dooierzak en het maag-darmstelsel. De produktie van AFP bij de foetus stijgt in het tweede trimester tot $30 \mathrm{mg} / \mathrm{dag}$ (Seppälä e.a. 1978). Sinds de invoering van de radio-immunoassay-bepaling (Ruoslahti en Seppälä 1971) is komen vast te staan dat een verhoogde concentratie van AFP in vruchtwater een relatie heeft met aangeboren afwijkingen zoals neurale buisdefecten (Brock en Sutcliffe 1972, Weiss e.a. 1976a, 1976b en 1977).

Buiten de foetale periode wordt AFP in grote hoeveelheden in het serum van de mens aangetroffen bij een primair levercarcinoom, teratocarcinoom of maligne tumoren die dooierzak-elementen bevatten. Dit is de reden dat AFP ook als "tumor marker" wordt gebruikt.

Het is bekend dat AFP ook fysiologisch bij kinderen en volwassenen in uiterst lage concentraties voorkomt.

In 1983 werd de AFP-bepaling ter bevestiging van de diagnose gebroken vliezen voor het eerst beschreven (Rochelson e.a. 1983). Deze auteurs vermeldden een sensitiviteit en specificiteit van $84 \%$ respectievelijk $94 \%$. Wel dient te worden opgemerkt dat de test werd uitgevoerd bij een groep patiënten met een zekere diagnose. Rochelson e.a. publiceerden in 1987 een monoclonale antilichaamtest waarmee zelfs een sensitiviteit van $98 \%$ en specificiteit van $100 \%$ werd bereikt.

Dergelijk goede resultaten werden niet door iedereen gevonden (Huber e.a. 1983, Hjertberg e.a. 1987).

Deze tegenstrijdige resultaten waren een reden te meer om de AFP-bepaling op te nemen in dit onderzoek.

\subsubsection{Bepalingsmethode van AFP}

Voor de bepaling van het AFP werd gebruik gemaakt van de commerciële AFP-RIA kit van Amersham (IM984). Deze kit is bedoeld om AFP te bepalen in serum en vruchtwater. De bepaling kan worden uitgevoerd bij concentraties die liggen tussen de 0 en $400 \mathrm{ng} / \mathrm{ml}$. De standaard-oplossingen zijn gecalibreerd tegen de International 
hoofdstuk 6

Agency Research on Cancer(IARC)-standaard 72/225. De gevoeligheid van de test is $2 \mathrm{ng} / \mathrm{ml}$. Als concentraties moeten worden bepaald die hoger zijn dan $400 \mathrm{ng} / \mathrm{ml}$ dan moet het te onderzoeken vocht worden verdund. Daar met andere verdunningsmiddelen bij een $\mathrm{pH}$ van 7,4 zoals $0,04 \mathrm{M}$ Sörensenbuffer of $4 \%$ Bovien Serum Albumine (BSA) matrix-effecten optraden werd verdund met serum. Ook bij volwassenen komt AFP in kleine hoeveelheden in het serum voor; voor de daardoor toegevoegde AFP werd gecorrigeerd.

Alvorens de AFP-concentraties, in fluor vaginalis en cervixslijm, konden worden bepaald moest eerst een extractie worden uitgevoerd. De methode van extractie is beschreven in paragraaf 6.3.1.

\subsubsection{AFP-bepaling bij patiënten met een zekere diagnose}

In de groep, waarbij de diagnose bekend was, werden in vruchtwater, serum, urine, fluor vaginalis en cervixslijm AFP-concentraties bepaald. De gemiddelde AFP-concentratie \pm S.D. in het afgenomen vocht bij de verschillende amenorroeklassen en het aantal uitgevoerde bepalingen is vermeld in tabel 72 .

Tabel 72: De gemiddelde concentratie van AFP (gem. AFP-conc.) \pm S.D. (ng/ml) bij patiënten met een zekere diagnose in vruchtwater (vrw.), serum en urine in de verschillende amenorroeklassen en het aantal uitgevoerde bepalingen.

\begin{tabular}{|c|c|c|c|}
\hline & $\begin{array}{r}\text { gem. AFP-conc. } \\
\text { vrw. } \pm \text { S.D. } \\
(\mathrm{ng} / \mathrm{ml})\end{array}$ & $\begin{array}{r}\text { gem. AFP-conc. } \\
\text { serum } \pm \text { S.D. } \\
(\mathrm{ng} / \mathrm{ml})\end{array}$ & $\begin{array}{r}\text { gem. AFP-conc. } \\
\text { urine } \pm \text { S.D. } \\
(\mathrm{ng} / \mathrm{ml})\end{array}$ \\
\hline \multicolumn{4}{|l|}{$\begin{array}{r}\text { amenorroe } \\
\text { (weken) }\end{array}$} \\
\hline 16 tot 20 & $96.317 \pm 97.027$ & $45,1 \pm 23,7$ & $56.6 \pm 16.8$ \\
\hline 20 tot 24 & $22.634 \pm 42.556$ & $132.1 \pm 73,0$ & $100,1 \pm 93,3$ \\
\hline 24 tot 28 & $6.778 \pm 6.207$ & $167.0 \pm 104.8$ & $129,4 \pm 115,5$ \\
\hline 28 tot 32 & $1.716 \pm 580$ & $221.6 \pm 77.8$ & $102.5 \pm 130.7$ \\
\hline 32 tot 36 & $587 \pm$ & $196,2 \pm 83,7$ & $109,7 \pm 143,5$ \\
\hline 36 tot 42 & $277 \pm$ & $118,4 \pm 85,8$ & $63,3 \pm 47,3$ \\
\hline aantal & 142 & 198 & 196 \\
\hline
\end{tabular}

In tabel 72 is te zien dat de concentratie van AFP in vruchtwater daalt met het toenemen van de amenorroeduur. Vanaf de $16^{\mathrm{e}}$ week neemt, in dit onderzoek, het serum-AFP toe om weer te "dalen" na de $36^{e}$ week. De concentratie van AFP in urine is vrijwel constant gedurende de zwangerschap. De gevonden concentraties van AFP, in het vruchtwater, zijn vergelijkbaar met literatuurgegevens (Seppälä en Ruoslahti 
1972, Weiss e.a. 1976a, Barford e.a. 1985). Ook de AFP-serumwaarden en urinewaarden zijn vergelijkbaar met literatuurgegevens (Seppälä 1978, Barford e.a. 1985). De concentratie van AFP in de andere lichaamsvloeistoffen, fluor vaginalis en cervixslijm, is niet direct te bepalen eerst moet een extractie plaatsvinden. Om de concentraties te kunnen vergelijken moeten de concentraties AFP in vruchtwater, serum en urine eerst per gram eiwit woren berekend. De eiwitconcentraties zijn vermeld in paragraaf 6.3. Tabel 73 vermeldt de AFP/eiwit-ratio in vruchtwater en serum.

Tabel 73: De gemiddelde AFPleiwit-ratio (gem.AFP-conc.) \pm S.D. van vruchtwater (vrw.) en serum per amenorroeklasse en het aantal uitgevoerde bepalingen.

gem. vrw. AFP-conc. gem. serum AFP-conc.

\pm S.D. (ng/g.e.) $\quad \pm$ S.D. (ng/g.e.)

amenorroe

(weken)

16 tot 20

20 tot 24

24 tot 28

28 tot 32

32 tot 36

36 tot 42

aantal

$\begin{array}{rr}14.509 \pm 14.146 \\ 1.590 \pm 1.832 \\ 1.852 \pm 3.944 \\ 337 \pm & 104 \\ 164 \pm & 69 \\ 108 \pm & 89\end{array}$

129
$0,7 \pm 0,4$
$2,0 \pm 1,2$
$2,8 \pm 2,0$
$3,8 \pm 1,5$
$3,4 \pm 1,4$
$2,0 \pm 1,5$

126

In tabel 73 ontbreekt de AFP/eiwit-ratio voor urine, met de in dit onderzoek gebruikte methode was immers veelal géen eiwit aantoonbaar. "Verdunning" door urine, in vaginaal afgelopen vloeistof, kan wel een storende invloed hebben op de totale AFP/eiwit-ratio, in de "gemengde" vloeistof.

De AFP/eiwit-ratio in serum wordt door de hoge concentratie van eiwit heel klein.

Vijf semen monsters van gezonde, fertiele mannen leverden niet detecteerbare AFP-concentraties op $(<2 \mathrm{ng} / \mathrm{ml})$.

De AFP/eiwit-ratio in fluor vaginalis en cervixslijm is weergegeven in tabel 74 . 
hoofdstuk 6

Tabel 74: De gemiddelde AFPleiwit-ratio (gem. AFP-conc.) \pm S.D. in fluor vaginalis en cervixslijm per amenorroeklasse en het aantal uilgevoerde bepalingen.

$\begin{array}{rr}\text { gem. AFP-conc. van } & \text { gem. AFP-conc. van } \\ \text { fluor vaginalis } \pm & \text { cervixslijm } \pm \text { S.D. } \\ \text { S.D. (ng/g.e.) } & \text { (ng/g.e.) }\end{array}$

amenorroe
(weken)

16 tot 20

20 tot 24

24 tot 28

28 tot 32

32 tot 36

36 tot 42

$\begin{array}{rlr}128,6 & \pm 162,3 \\ 183,3 & \pm & 80,7 \\ 97,7 & \pm & 59,8 \\ 112,2 & \pm & 76,2 \\ 255,7 & \pm & 249,7 \\ 52,8 & \pm & 60,6\end{array}$

aantal

$\begin{array}{ccc}0.6 & \pm & - \\ - & \pm & - \\ - & \pm & - \\ 0.0 & \pm & - \\ 1,7 & \pm & - \\ 5,5 & \pm & 4,1\end{array}$

15

Uit tabel 74 blijkt dat de AFP/eiwit-ratio van fluor vaginalis nogal wisselt en niet afhankelijk is van de amenorroe. De AFP/eiwit-ratio in vruchtwater is van dezelfde orde van grootte als die in fluor vaginalis vanaf de $28^{e}$ week van de zwangerschap. De cervixslijm AFP/eiwit-ratio is veel lager dan die in het vruchtwater en cervixslijm en zal derhalve de diagnostiek van gebroken vliezen niet beïnvloeden.

\section{Conclusies}

1. Na de $28^{\circ}$ week van de zwangerschap zijn de AFP/eiwit-ratio in vruchtwater en die in fluor vaginalis vrijwel gelijk.

2. Urine kan, bij dubieus gebroken vliezen, een substantieel deel AFP leveren in vaginaal afgelopen vocht indien een weinig eiwit aanwezig is in de urine.

3. Serum, cervixslijm en semen leveren géen substantiële AFP-concentraties in vaginaal afgelopen vocht indien de concentraties worden uitgedrukt als een AFP/eiwit-ratio.

Bestudering van de concentraties in de verschillende vloeistoffen verkregen bij patiënten met een zekere diagnose (tabel 73 en tabel 74) laat zien dat er voor de verschillende klassen van amenorroeduur een verschillend afkappunt zou moeten worden vastgesteld. De vruchtwater AFP/eiwit-ratio is tot 28 weken hoog tot zeer 
hoog, voor deze amenorroeklassen kan een punt worden gekozen tussen de 500 en $1000 \mathrm{ng} / \mathrm{g}$.e.. Voor de amenorroe na 28 weken moet een veel lager afkappunt worden gekozen: tussen de 50 en $200 \mathrm{ng} / \mathrm{g}$.e.. Voor de amenorroe van 36 tot 42 weken is een zeer lage waarde (nabij $0 \mathrm{ng} / \mathrm{g}$.e.) het meest geschikt als afkappunt.

\subsubsection{AFP-bepaling bij patiënten met dubieus gebroken vliezen}

Bij de groep van 100 patiënten met dubieus gebroken vliezen, zoals beschreven in paragraaf 6.2.2, werd de AFP/eiwit-ratio bepaald.

Met behulp van de afkappunten zoals gegeven in de vorige paragraaf werd de sensitiviteit en specificiteit berekend. In figuur 20 is de ROC-curve weergegeven.

Figuur 20: ROC-curve van de AFPleiwit-ratio bij de afkappunten: 0, 50, 100, 150, 200 en 500 ng/g.e..

ROC-curve AFP/eiwit-ratio

dubieus gebroken vliezen

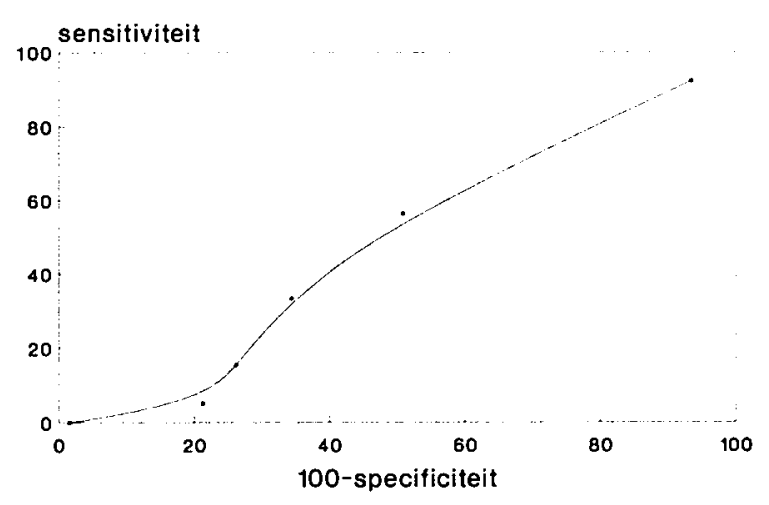

De ROC-curve in figuur 20 laat zien dat de AFP per gram eiwit niet is te gebruiken als betrouwbaar diagnosticum om gebroken vliezen aan te tonen bij patiënten met dubieus gebroken vliezen bij elke amenorroeduur. Hiermee worden de slechte resultaten van de AFP/eiwit-ratio, zoals beschreven in de literatuur (Huber e.a. 1983 en Hjertberg e.a. 1987), bevestigd.

Niet uitgesloten is echter dat vór de $32^{c}$ week deze bepaling wel een bruikbaar diagnosticum is. De aantallen in dit onderzoek laten verificatie van deze laatste conclusie niet toe. 
hoofdstuk 6

Conclusie

De AFP/eiwit-ratio is een onbruikbaar diagnosticum bij dubieus gebroken vliezen. De betekenenis van deze test kon in dit onderzoek vóór de $32^{\mathrm{e}}$ week onvoldoende worden beoordeeld. 


\section{- Resultaten van het onderzoek}

\subsection{Humaan Chorion Gonadotrophine}

\subsection{1 .1 Inleiding}

Humaan Chorion Gonadotrophine (hCG) werd ontdekt in urine van zwangere vrouwen in 1927 door Aschheim en Zondek. Daarna hebben vele onderzoekers aangetoond dat dit een glycoproteïne is dat tijdens de zwangerschap afkomstig is van de placenta. De aanwezigheid van hCG in vruchtwater is bekend sedert 1951 (Bruner). De ontwikkeling van een radio-immunoassay heeft de betrouwbaarheid van de bepalingen vergroot en heeft het mogelijk gemaakt om hCG te bestuderen tijdens de normale en de abnormale zwangerschap.

Het hCG-molecuul bestaat uit twee eiwitketens die alpha- en beta-subunit worden genoemd (Chard en Klopper 1982) en is verwant aan Luteiniserend Hormoon (LH), Follikel Stimulerend Hormoon (FSH) en Thyroid Stimulerend Hormoon (TSH).

Over de biologische functie is veel gefilosofeerd. Samengevat wordt hCG in verband gebracht met (Chard en Klopper 1982):

- het intact houden van het corpus luteum en de steroidproduktie van het corpus luteum (Luteotrope activiteit)

- stimulatie van de progesteronproduktie door de placenta

- stimulatie van de bijnier van de foetus en produktie van dehydroepiandrosteron (DHEA)

- stimulatie van de gonaden van de foetus, met name de produktie van testosteron door de testis

- remming van afstotingsreacties van de moeder gericht tegen het zwangerschapsprodukt.

De hCG-bepaling is, als diagnosticum bij gebroken vliezen, nooit beschreven. Om de hCG-bepaling hiervoor te gebruiken ligt minder voor de hand, omdat de concentratie in vruchtwater laag is in vergelijking tot die in serum en urine.

De concentratie in andere lichaamsvloeistoffen (cervixslijm, fluor vaginalis en semen) is echter nooit bestudeerd. Reden om in dit onderzoek aandacht te schenken aan deze bepaling. 
hoofdstuk 6

\subsubsection{Bepalingsmethode van $h C G$}

HCG werd in dit onderzoek bepaald met behulp van een commerciële immunoassaybepaling van Hybritech: "Tandem-E6". De bepaling is betrouwbaar uit te voeren in het gebied van 0 tot $200 \mathrm{U} / \mathrm{l}$ (gecalibreerd tegen de WHO-standaard MRC 75/537). Bij concentraties groter dan $200 \mathrm{U} / 1$ moet worden verdund. Om matrix-effecten te voorkomen werd vruchtwater verdund met serum van mannen, urine met urine van niet-zwangere vrouwen en serum met serum van mannen.

De betrouwbaarheid van de bepaling is $2 \mathrm{U} / \mathrm{h}$.

De gebruikte immunoassay-bepaling maakt gebruik van twee antilichamen waarbij het eerste gekoppeld is aan de "vaste fase" (plastic bolletjes) en het tweede antilichaam gekoppeld is aan een enzym. Het eerste monoclonale antilichaam is gericht tegen een unieke plaats op het hCG-molecuul. Derhalve wordt de totale hCG-concentratie bepaald. Er bestaat, onder normale omstandigheden, geen kruisreactie met LH, FSH of TSH.

Matrix-effecten met betrekking tot de homogene hCG-bepalingssystemen (1-stapsincubatie) moeten worden uitgesloten. Om dit te kunnen doen werden verdunningscurven van het WHO-referentiepreparaat MRC 73/537 gemaakt. Als verdunningsmedia werden gebruikt: serum (van mannen), urine (van niet zwangere vrouwen) en vruchtwater. De gevonden formules van de regressielijnen zijn weergegeven in tabel 75.

Tabel 75: Verdunningscurven van het WHO-preparaat MRC 751537 met behulp van verschillende verdunningsmedia.

\begin{tabular}{|c|c|c|c|}
\hline \multirow[b]{2}{*}{ medium } & \multicolumn{2}{|c|}{ regressielijn } & \multirow[t]{2}{*}{ r-waarde } \\
\hline & & & \\
\hline \multicolumn{4}{|l|}{ serum } \\
\hline voor waarden $\leq 100 \mathrm{U} / \Lambda$ & $y=0,937 x$ & $+\quad 1.76$ & $r=0,999$ \\
\hline voor waarden $>100 \mathrm{U} / \mathrm{A}$ & $y=0,722 x$ & $+10,30$ & $r=0.998$ \\
\hline \multicolumn{4}{|l|}{ urine } \\
\hline voor waarden $\leq 200 \mathrm{U} / \mathrm{n}$ & $y=1,012 x$ & $+\quad 3,70$ & $r=0,999$ \\
\hline voor waarden $<00 \mathrm{U} / \mathrm{l}$ & $y=0.793 x$ & $+16,20$ & $r=0,984$ \\
\hline \multicolumn{4}{|l|}{ vruchtwater } \\
\hline voor waarden $\leq 150 \mathrm{U} / \mathrm{n}$ & $y=1,028 x$ & - $\quad 0.59$ & $r=0,996$ \\
\hline voor waarden $>150 \mathrm{U} / \mathrm{h}$ & $y=0,604 x$ & $+23,80$ & $r=0,968$ \\
\hline
\end{tabular}

Uit tabel 75 kan worden geconcludeerd dat direct hCG is te bepalen, zonder matrixeffecten, voor serum tot $100 \mathrm{U} / \mathrm{h}$, voor urine tot $200 \mathrm{U} / \mathrm{l}$ en voor vruchtwater tot $150 \mathrm{U} / \mathrm{l}$. 
diagnostiek

\subsubsection{HCG-bepaling bij patiënten met een zekere diagnose}

De patiënten met een zekere diagnose, waarbij vruchtwater, bloed en urine werd afgenomen zijn beschreven in paragraaf 6.2.1. Het aantal bepalingen per amenorroegroep is vermeld in tabel 76.

De gemiddelde hCG-concentraties \pm S.D. bij patiënten met een zekere diagnose in vruchtwater, serum en urine, zijn weergegeven in tabel 76.

Tabel 76: Gemiddelde concentratie \pm S.D. (gem. conc.) van hCG in vruchtwater (vrw.), serum en urine per amenorroeklasse en het aantal bepalingen bij patiënten met een zekere diagnose.

\begin{tabular}{|c|c|c|c|}
\hline & $\begin{array}{l}\text { gem. vrw.-conc. } \\
\pm \text { S.D. (U/I) }\end{array}$ & $\begin{array}{r}\text { gem. serumconc. } \\
\pm \text { S.D. (U/ })\end{array}$ & $\begin{array}{r}\text { gem. urineconc. } \\
\text { 土 S.D. (U/I) }\end{array}$ \\
\hline \multicolumn{4}{|l|}{$\begin{array}{r}\text { amenorroe } \\
\text { (weken) }\end{array}$} \\
\hline 16 tot 20 & $3.120 \pm 1.759$ & $24.712 \pm 13.661$ & $10.303 \pm$ \\
\hline 20 tot 24 & $1.810 \pm 945$ & $17.819 \pm 12.206$ & $6.122 \pm 6.070$ \\
\hline 24 tot 28 & $1.989 \pm 2.072$ & $24.093 \pm 19.625$ & $12.636 \pm 11.531$ \\
\hline $28 \operatorname{tot} 32$ & $829 \pm 633$ & $35.285 \pm 52.211$ & $10.824 \pm 7.881$ \\
\hline $32 \operatorname{tot} 36$ & $1.608 \pm 1.958$ & $31.984 \pm 14.109$ & $8.684 \pm 10.273$ \\
\hline 36 tot 42 & $712 \pm 578$ & $22.453 \pm 14.129$ & $7.438 \pm 7.809$ \\
\hline aantal & 145 & 198 & 196 \\
\hline
\end{tabular}

De gemiddelde hCG-concentratie van vaginaal afgelopen vruchtwater, zoals vermeld in tabel 76, is vergelijkbaar met literatuurgegevens (Wide en Hobson 1967, Berle 1969 , Dawood e.a. 1977, Dattatreyamurty e.a. 1979, Schindler 1982, Chard en Klopper 1982).

De hoge gemiddelde hCG-waarde van vruchtwater in de amenorroegroep van 32 tot 36 weken wordt veroorzaakt door één waarneming. Een verklaring voor deze afwijkende waarde werd niet gevonden. Bij verwaarlozen van deze uitbijter is de gemiddelde hCG-concentratie van vruchtwater in de amenorroeklasse van 32 tot 36 weken: $1194 \pm 892 \mathrm{U} / 1$.

De gemiddelde hCG-concentratie in vruchtwater is veel lager dan die in serum en urine. Dit maakt de hCG-bepaling op voorhand geen ideale methode bij de diagnostiek van gebroken vliezen. In tabel 76 is ook te zien dat een grote standaarddeviatie wordt gevonden bij de hCG-bepaling. 
hoofdstuk 6

De enorm wisselende interindividuele hCG-concentratie in de drie lichaamsvochten zal het vaststellen van afkappunten bemoeilijken. Ook zal dit de betekenis van de hCG-bepaling in de groep met dubieus gebroken vliezen niet ten goede komen.

Bij de hCG-bepaling in fluor vaginalis en cervixslijm moet eerst een extractie worden uitgevoerd. De hCG wordt dan weergegeven in U/gram eiwit (tabel 77). De eiwit-concentraties van vruchtwater en serum zijn weergegeven in paragraaf 6.3.1.

Tabel 77: De gemiddelde hCG/eiwit-ratio (gem.conc.) in vruchtwater (vrw.), serum, fluor vaginalis (fluor) en cervixslijm (cerv.sl.) per amenorroeklasse bij patiënten met cen zekere diagnose en het aantal uitgevoerde bepalingen.

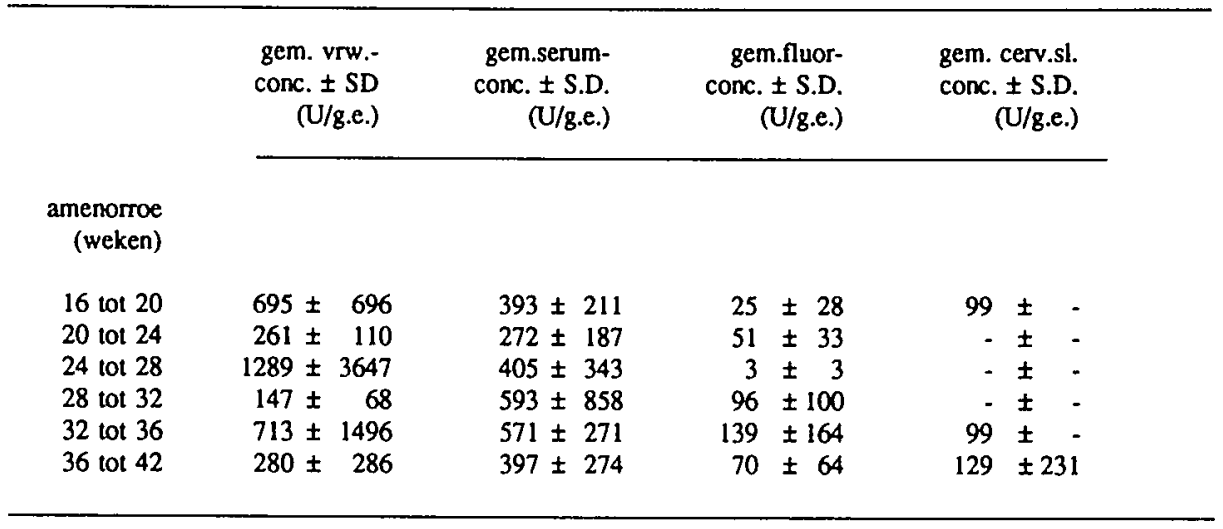

In tabel 77 zijn de hCG-concentraties in urine per gram eiwit niet weergegeven daar eiwit met de in dit onderzoek gebruikte bepaling zelden kan worden aangetoond. Wel kan urine door vermenging met vaginaal afgelopen vocht de eiwit-concentratie verlagen en de hCG-concentratie per gram eiwit sterk doen toenemen. Daarom zal urinebijmenging de diagnostiek van gebroken vliezen door middel van de hCG-bepaling negatief beïnvloeden.

Tabel 77 laat zien dat de concentratie van hCG per gram eiwit in serum vergelijkbaar is met de hCG/eiwit-ratio in vruchtwater. Daarom zal ook bloedbijmenging de betrouwbaarheid van de diagnostiek bij dubieus gebroken vliezen, met behulp van de hCG-bepaling, negatief beïnvloeden.

Uit tabel 77 blijkt tevens dat de gemiddelde hCG/eiwit-ratio in fluor vaginalis en cervixslijm relatief laag is en ligt in het gebied van de vruchtwater-hCG/eiwit-ratio. Daardoor kan ook fluor vaginalis en cervixslijm de diagnostiek, bij dubieus gebroken vliezen met behulp van de hCG-bepaling, negatief beïnvloeden. 
diagnostiek

\section{Conclusies}

1. Het hormoon hCG werd als diagnosticum bij dubieus gebroken vliezen in de literatuur terecht niet eerder beschreven.

2. De hCG-bepaling bij dubieus gebroken vliezen per gram eiwit zal door bloedbijmenging bij vaginaal afgelopen vocht ernstig worden gestoord. Urinebijmenging geeft eveneens problemen. Fluor vaginalis en cervixslijm heeft per gram eiwit een hCG-concentratie die voor een individuele patiënte in het laag-normale "vruchtwatergebied" ligt.

\subsubsection{Het vaststellen van afkappunten voor het berekenen van de sensitiviteit} en specificiteit bij de $h C G$-bepaling

Gezien de grote spreiding van de hCG/eiwit-ratio's in vruchtwater, serum, urine, fluor vaginalis en cervixslijm is het moeilijk om een optimaal afkappunt vast te stellen. Om dit probleem enigermate te vereenvoudigen werd een frequentieverdeling gemaakt (tabel 78).

Tabel 78: Frequentieverdeling van de hCGleiwit-ratio's van vruchtwater (vrw.), serum, urine, fluor vaginalis (fluor) en cervixslijm (cerv.sl.) bij patiënten met een zekere diagnose en het aantal uitgevoerde bepalingen.

\begin{tabular}{rrrrrr} 
& $\begin{array}{r}\text { vrw. } \\
\text { (U/g.e) }\end{array}$ & $\begin{array}{r}\text { serum } \\
\text { (U/g.e.) }\end{array}$ & $\begin{array}{r}\text { urine } \\
\text { (U/g.e.) }\end{array}$ & $\begin{array}{r}\text { fluor } \\
\text { (U/g.e.) }\end{array}$ & $\begin{array}{r}\text { cerv.sl. } \\
\text { (U/g.e.) }\end{array}$ \\
\cline { 2 - 6 } concentratie & & & & & \\
(U/g.e.) & & & & & \\
0 & 0 & 0 & 0 & 1 & 0 \\
$>0$ en $<100$ & 26 & 14 & 1 & 39 & 3 \\
2100 en $<200$ & 31 & 21 & 6 & 11 & 5 \\
$\geq 200$ en $<300$ & 29 & 21 & 1 & 4 & 3 \\
2300 en $<400$ & 13 & 16 & 2 & 0 & 2 \\
2400 en $<500$ & 9 & 12 & 2 & 0 & 0 \\
2500 en $<600$ & 4 & 9 & 4 & 0 & 0 \\
2600 en $<700$ & 2 & 9 & 1 & 1 & 0 \\
$\geq 700$ en $<800$ & 2 & 9 & 1 & 0 & 0 \\
2800 en $<900$ & 1 & 3 & 2 & 0 & 0 \\
$\geq 900$ en $<1000$ & 4 & 4 & 2 & 0 & 14 \\
$\geq 1000$ & 6 & 8 & 176 & 0 & \\
aantal & 127 & 126 & 198 & 56 & \\
\hline
\end{tabular}


hoofdstuk 6

In tabel 78 kan gezien worden dat de meeste hCG/eiwit-ratio's voor vruchtwater liggen tussen de 0 en $500 \mathrm{U} / g . e$. . De ratio's van bloed, fluor vaginalis en cervixslijm liggen in hetzelfde gebied. Gelet op tabel 78 werden de volgende afkappunten als benedengrens genomen: $0,25,50,75,100,200$ en $400 \mathrm{U} / g . e . ;$ als bovengrens: $500 \mathrm{U} / g . e .$.

\subsubsection{HCG-bepaling bij patiënten met dubieus gebroken vliezen}

In het vaginaal afgelopen vocht van de eerder beschreven 100 patiënten, waarbij aan het gebroken zijn van de vliezen werd getwijfeld, is hCG per gram eiwit bepaald. Alvorens hCG kon worden bepaald werd een extractie uitgevoerd, zoals beschreven in paragraaf 6.3 .

Met behulp van de afkappunten die in de vorige paragraaf zijn beschreven werd de sensitiviteit en specificiteit berekend. De resultaten zijn weergegeven in figuur 21 .

Figuur 21: De ROC-curve voor hCG bij de afkappunten 0,25, 50, 75, 100, 200. en $400 \mathrm{U} / \mathrm{g}$.e. in de groep met dubieus gebroken vliezen. Als bovengrens werd $500 \mathrm{U} / \mathrm{g}$. e. genomen.

\section{ROC-curve hCG/eiwit-ratio dubieus gebroken vliezen}

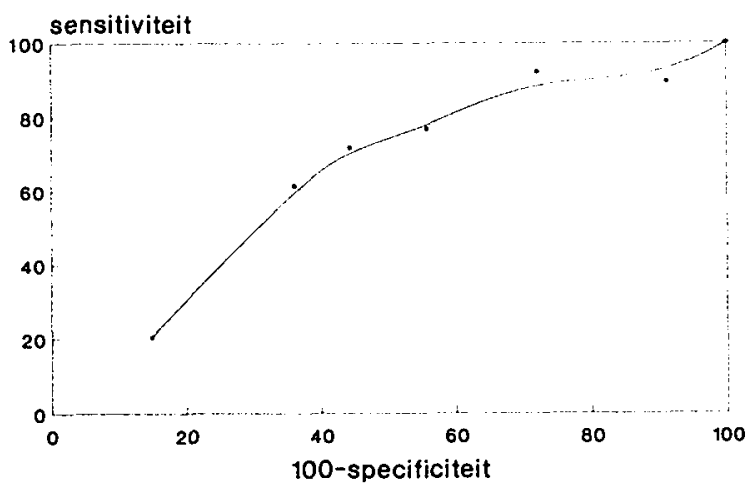

De sensitiviteit en specificiteit, zoals weergegeven in figuur 21 , zijn matig te noemen. De voorspellende waarde van een positieve test en van een negatieve test bij de gebruikte afkappunten zijn weergegeven in tabel 79 . 
Tabel 79: De voorspellende waarde van een positieve test en de voorspellende waarde van een negatieve test bij verschillend afkappunten voor de hCG/eiwit-ratio's.

\begin{tabular}{rrr}
\hline & $\begin{array}{r}\text { voorspellende } \\
\text { waarde pos. test (\%) }\end{array}$ & $\begin{array}{r}\text { voorspellende } \\
\text { waarde neg. test (\%) }\end{array}$ \\
\cline { 2 - 2 } afkappunt & & \\
(U/g.e.) & & 0,0 \\
0 & 39,0 & 60,0 \\
0 tot 500 & 38,9 & 85,0 \\
25 tot 500 & 45,0 & 75,0 \\
50 tot 500 & 46,7 & 75,6 \\
75 tot 500 & 50,9 & 72,2 \\
100 tot 500 & 52,2 & 62,7 \\
200 tot 500 & 47,1 & 60,6 \\
400 tot 500 & 0,0 & \\
\hline
\end{tabular}

De beste voorspellende waarden worden gevonden bij een "afkapgebied" van 75 tot 500 en van 100 tot $500 \mathrm{U} / g . e$. . De voorspellende waarden zijn vergelijkbaar met de voorspellende waarden van de varentest bij dubieus gebroken vliezen.

\section{Conclusie}

De hCG-bepaling werd nog niet eerder in de literatuur beschreven als diagnosticum bij dubieus gebroken vliezen. Deze bepaling blijkt geen doorbraak op te leveren bij de diagnostiek van dubieus gebroken vliezen. De betekenis van de bepaling is vergelijkbaar met andere suboptimale bepalingen die wel in de literatuur zijn beschreven. 
hoofdstuk 6

- Resultaten van de bepalingen

\subsection{Humaan Placental Lactogen}

\subsubsection{Inleiding}

Het humane Placental Lactogen (hPL) is een hormoon dat bekend is sinds de zestiger jaren (Ito en Higashi 1961 en Josimovich en MacLaren 1962). Sinds radio-immunoassay-bepalingen mogelijk zijn kan hPL nauwkeurig worden bepaald. Kruisreakties met andere hormonen treden nauwelijks op (Chard en Klopper 1982).

Als mogelijke functies van hPL kunnen worden genoemd (Chard en Klopper 1982):

- het bevorderen van de groei van de foetus

- mammotrope en lactatie-bevorderende werking

- luteotrope activiteit

- erythropoëtische activiteit

- mobilisatie van vrije vetzuren

- anti-insuline effect op de suikerstofwisseling

- anabole werking op het nitrogeen-metabolisme

- inhibitie van de fibrinolyse

- inhibitie van de afstotingsreactie van de moeder gericht tegen de foetus.

De bepaling van hPL is gebruikt als maat voor de placentafunctie (Schindler 1982). Sinds het beschikbaar komen van meer betrouwbare methoden, met name de cardiotocografie, wordt deze bepaling vrijwel niet meer gebruikt.

De hPL-bepaling is in de literatuur éénmaal beschreven als diagnosticum bij gebroken vliezen (Huber e.a. 1983). Deze auteurs concluderen dat de hPL-bepaling bij dubieus gebroken vliezen niet zinvol is. Er werd geen sensitiviteit en specificiteit berekend, omdat bij zowel staande als gebroken vliezen nauwelijks hPL, in vaginaal afgelopen vocht, werd aangetoond. Daar in het onderhavige onderzoek zoveel mogelijk vocht werd verzameld en het protocol voorzag in een extractiemethode werd de hPL-bepaling, ondanks de slechte resultaten van Huber e.a. (1983), toch in het protocol opgenomen. 


\subsubsection{Bepalingsmethode van $h P L$}

HPL werd, in dit onderzoek, bepaald met behulp van een immunoradiometrische assay (IRMA). Gebruikt werd de commercieel beschikbare kit van Amersham: Amerlex hPL IRMA kit. De kit kan worden gebruikt in het gebied van 0 tot $12,3 \mathrm{mU} / 1$ en is gecalibreerd tegen het WHO-standaardpreparaat MRC 73/545. Het principe van de bepaling is gebaseerd op de gelijktijdige reactie van een radioactief gelabeld anti-hPL antilichaam en een Amerlex anti-hPL antilichaam (als vaste fase: latex-partikels), samengebracht in de te onderzoeken vloeistof. De hoeveelheid 125-I-gelabelde anti-hPL die is gebonden aan de Amerlex hPL is een maat voor de hPL-concentratie in de te onderzoeken vloeistof. Het scheiden van dit complex geschiedde door centrifugeren van de oplossing en te decanteren. Door meting van het radioactieve Jodium, gebonden aan het anti-hPL, en de concentraties te vergelijken met standaard-oplossingen kan de concentratie in de te onderzoeken vloeistof worden berekend.

Matrix-effecten dienen te worden uitgesloten. Verdunningscurven van het WHO-referentiepreparaat $73 / 545$ met als verdunningsmedia urine (van niet zwangere vrouwen die geen hormonale anticonceptiemiddelen of medicamenten gebruikten) en serum (van mannen) werden bepaald: tabel 80 .

Tabel 80: Verdunningscurven van het WHO-referentiepreparaat MRC $73 / 545$ met verschillende verdunningsmedia.

regressielijn r-waarde

medium

voor urine

met als verdunningsmedium urine met als verdunningsmedium serum

$$
\begin{array}{lll}
y=0.6234 x & +0.046 & r=0.9986 \\
y=0.5956 x & -0.039 & r=0,9998
\end{array}
$$

voor vruchtwater

met als verdunningsmedium urine met als verdunningsmedium senum

$$
\begin{array}{lll}
y=0,5956 x & +0,09 & r=0,9978 \\
y=0,6155 x & +0,09 & r=0.996
\end{array}
$$

Uit tabel 80 kan worden geconcludeerd dat de verdunningscurven een lineair karakter hebben en er sprake is van parallellisme. Daar de gevonden waarden zijn gecalibreerd tegen MRC 73/545 (de kit-calibrator was MRC 75/537, maar tijdens de proef niet voorhanden) is als omrekeningsfactor gehanteerd: 
hoofdstuk 6

voor urine:

gevonden waarde $\times 1,52$

voor vruchtwater:

gevonden waarde $\times 1,27$.

Serum als verdunningsmiddel is verworpen, in de plaats werd gekozen voor urine van niet zwangere vrouwen die geen anticonceptiemiddelen of medicamenten gebruikten.

\subsubsection{HPL-bepaling bij patiënten met een zekere diagnose}

In de groep patiënten, zoals beschreven in paragraaf 6.2.1, waarbij de diagnose bekend was, werd in vruchtwater, serum en urine de hPL-concentratie direct bepaald. Bij fluor vaginalis en de cervixslijm-monsters werd eerst een extractiemethode uitgevoerd. Deze extractiemethode is beschreven in paragraaf 6.3. De hPL-concentratie in vruchtwater, serum en urine zijn vermeld in tabel 81 .

Tabel 81: Gemiddelde hPL-concentratie (gem. conc.) (mU/l) in vruchtwater (vrw.), serum (ser.) en urine in de verschillende amenorroeklassen bij patiënten met een zekere diagnose en het aantal uitgevoerde bepalingen.

\begin{tabular}{|c|c|c|c|}
\hline & $\begin{array}{l}\text { gem. vrw.-conc. } \\
\pm \text { S.D. }(\mathrm{mU} / \mathrm{l})\end{array}$ & $\begin{array}{l}\text { gem. ser.-conc. } \\
\pm \text { S.D. }(\mathrm{mU} / \mathrm{l})\end{array}$ & $\begin{array}{l}\text { gem. urine-conc. } \\
\pm \text { S.D. }(\mathrm{mU} / \mathrm{)})\end{array}$ \\
\hline \multicolumn{4}{|l|}{$\begin{array}{r}\text { amenorroe } \\
\text { (weken) }\end{array}$} \\
\hline 16 tot 20 & $0,42 \pm 0,15$ & $1,97 \pm 1.80$ & $0,02 \pm 0,01$ \\
\hline 20 tot 24 & $0,96 \pm 1,05$ & $2,77 \pm 1.21$ & $0.98 \pm 0.26$ \\
\hline 24 tot 28 & $0,65 \pm 0,42$ & $3,29 \pm 1,79$ & $0.09 \pm 0.07$ \\
\hline 28 tot 32 & $0,88 \pm 0,51$ & $5,27 \pm 1,31$ & $0,42 \pm 0,16$ \\
\hline 32 tot 36 & $0,82 \pm 0,36$ & $7,13 \pm 2,14$ & $0,20 \pm 0,14$ \\
\hline 36 tot 42 & $0,71 \pm 0,38$ & $7,60 \pm 3,63$ & $0,19 \pm 0,11$ \\
\hline aantal & 145 & 199 & 196 \\
\hline
\end{tabular}

De concentraties van hPL, zoals gegeven in tabel 81 , zijn vergelijkbaar met de concentraties die zijn vermeld in de literatuur (Chard en Klopper 1982 en Schindler 1982). Uit tabel 81 blijkt dat de vruchtwater-concentratie van hPL ongeveer gelijk blijft gedurende de zwangerschap. De serum-concentratie van hPL neemt toe, bij het vorderen van de zwangerschap. De urineconcentratie van hPL is laag.

Daar de hPL-concentratie in fluor vaginalis en cervixslijm niet direct kon worden bepaald moest eerst een extractie-methode worden uitgevoerd. De concentratie van hPL wordt dan in mUnits/gram eiwit berekend. 
Ook de concentratie hPL in de andere lichaamsvloeistoffen werd omgerekend naar mUnits/gram eiwit (tabel 82).

Tabel 82: De gemiddelde hPL-concentratie (gem. conc.) per gram eiwit $\pm S . D$. in vruchtwater (vrw.) en serum in de verschillende amenorroeklassen bij patiënten met een zekere diagnose en het aantal uitgevoerde bepalingen.

gem. vrw.-conc. \pm

S.D. (mU/g.e.) gem. serumconc. \pm

S.D. (mU/g.e.) amenorroe

(weken)

16 tot 20

20 tot 24

24 tot 28

28 tot 32

32 tot 36

36 tot 42

aantal
$0,07 \pm 0,05$

$0,09 \pm 0,04$

$0,09 \pm 0,07$

$0,17 \pm 0,08$

$0,24 \pm 0,10$

$0,26 \pm 0.13$

129
$0,03 \pm 0,03$
$0,04 \pm 0,02$
$0,05 \pm 0,03$
$0,09 \pm 0,03$
$0,12 \pm 0,04$
$0,13 \pm 0,07$

126

Tabel 82 laat zien dat de hPL-concentratie per gram eiwit in het serum gemiddeld lager is maar, gelet op de standaarddeviatie, in vruchtwater van dezelfde orde van grootte.

Met de gehanteerde methode wordt zelden eiwit in urine aangetoond, maar urine kan door verdunning van vaginaal afgelopen vocht, bij dubieus gebroken vliezen, fout-positieve uitslagen veroorzaken als de hPL-bepaling per gram eiwit wordt gebruikt als diagnosticum bij dubieus gebroken vliezen.

In fluor vaginalis werd in één monster hPL aangetoond: $0,03 \mathrm{mU} / \mathrm{g}$.e.. De andere monsters gaven waarden kleiner dan het detectieniveau van $0,01 \mathrm{mU} / \mathrm{g}$.e.. In cervixslijm werd geen hPL aangetoond. Ook in semen van 5 fertiele mannen werd geen $\mathrm{hPL}$ aangetoond $(<0,01 \mathrm{mU} / \mathrm{l})$.

De afkappunten werden bepaald met behulp van de frequentie-verdeling zoals gegeven in tabel 83. 
hoofdstuk 6

Tabel 83: Frequentieverdeling van de concentraties van hPL per gram eiwit in vruchtwater (vrw.), serum. fluor vaginalis (fuor) en cervixslijm (cerv. sl.) en het aantal uitgevoerde bepalingen.

\begin{tabular}{|c|c|c|c|c|}
\hline & $\begin{array}{l}\text { vrw. } \\
\text { aantal }\end{array}$ & $\begin{array}{l}\text { serum } \\
\text { aantal }\end{array}$ & $\begin{array}{r}\text { fluor } \\
\text { aantal }\end{array}$ & $\begin{array}{r}\text { cerv. sl. } \\
\text { aantal }\end{array}$ \\
\hline \multicolumn{5}{|l|}{$\begin{array}{r}\text { concentratie } \\
\text { hPl (mU/g.e.) }\end{array}$} \\
\hline 0 & 6 & 9 & 55 & 14 \\
\hline$>0$ en $\leq 0.1$ & 22 & 60 & 1 & 0 \\
\hline$>0,1$ en $\leq 0,2$ & 34 & 51 & 0 & 0 \\
\hline$>0,2$ en $\leq 0,3$ & 33 & 6 & 0 & 0 \\
\hline$>0,3$ en $\leq 0,4$ & 24 & 0 & 0 & 0 \\
\hline$>0,4$ en $\leq 0,5$ & 5 & 0 & 0 & 0 \\
\hline$>0.5$ en $\leq 0.6$ & 2 & 0 & 0 & 0 \\
\hline$>0.6$ en $\leq 0.7$ & 1 & 0 & 0 & 0 \\
\hline$>0,7$ en $\leq 0.8$ & 0 & 0 & 0 & 0 \\
\hline$>0,8$ en $\leq 0,9$ & 0 & 0 & 0 & 0 \\
\hline$>0,9$ en $\leq 0,1$ & 0 & 0 & 0 & 0 \\
\hline$>1,0$ & 0 & 0 & 0 & 0 \\
\hline aantal & 127 & 126 & 56 & 14 \\
\hline
\end{tabular}

Beproefd werden de afkappunten: $\geq 0,>0, \geq 0,05, \geq 0,1, \geq 0,2, \geq 0,3$ en $\geq 0,4$.

\section{Conclusie}

De concentratie van hPL in serum is relatief hoog, die in urine is relatief laag; de concentratie van hPL in vruchtwater ligt daar tussen in. Fluor vaginalis en cervixslijm bevatten zelden hPL. Semen bevat geen hPL.

\subsubsection{HPL-bepaling bij patiënten met dubieus gebroken vliezen}

In de groep met dubieus gebroken vliezen, zoals beschreven in paragraaf 6.2, werd na een extractiemethode hPL bepaald. De sensitiviteit en specificiteit bij de verschillende afkappunten voor de hPL-concentraties per gram eiwit werden berekend en zijn weergegeven in een ROC-curve: figuur 22. 
Figuur 22: ROC-curve van de $h P$-concentratie per gram eiwit bij de afkappunten $\geq 0,>0,0, \geq 0,05, \geq 0,2, \geq 0,3$ en $\geq 0,4 \mathrm{mU} / \mathrm{gram}$ eiwil.

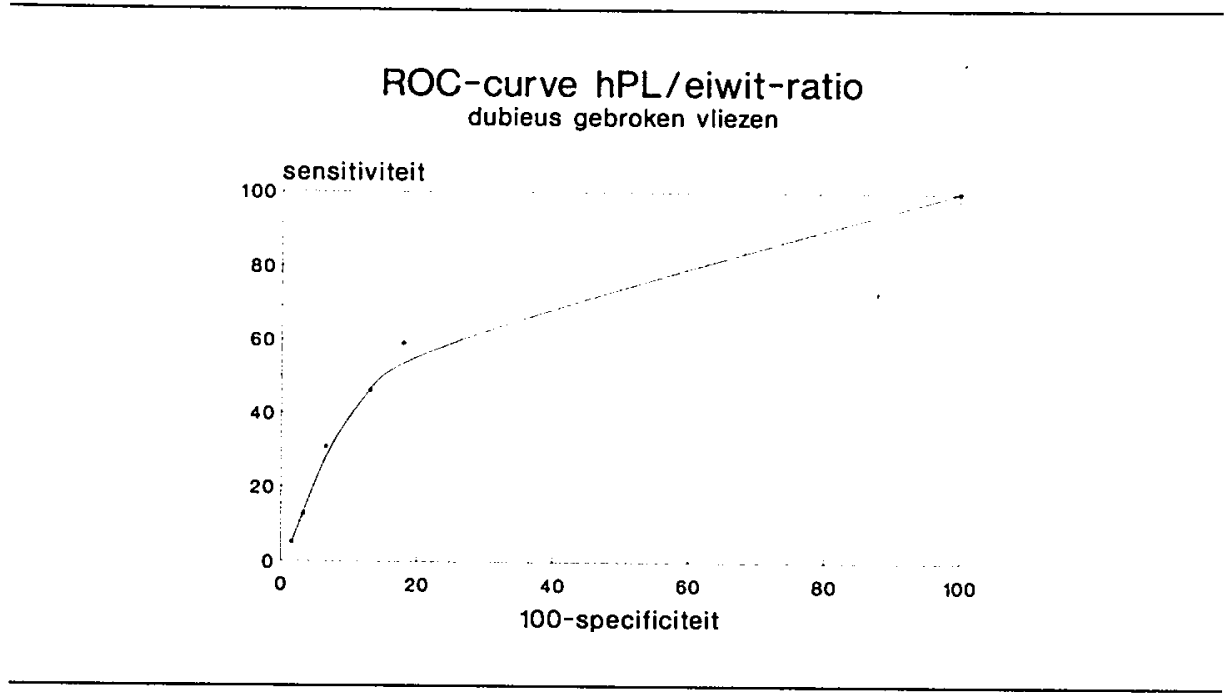

Naast de sensitiviteit en specificiteit bij de bovengenoemde afkappunten werd ook de voorspellende waarde van een positieve en een negatieve test berekend (tabel 84).

Tabel 84: De voorspellende waarde van een positieve test en van een negatieve test bij de verschillende afkappunten voor de ratio hPL/gram eiwit.

\begin{tabular}{rrr} 
& $\begin{array}{r}\text { voorspellende } \\
\text { waarde pos. test } \\
(\%)\end{array}$ & $\begin{array}{r}\text { voorspellende } \\
\text { waarde neg. test } \\
(\%)\end{array}$ \\
\cline { 2 - 3 } $\begin{array}{r}\text { concentratie } \\
\text { (mU/g.e.) }\end{array}$ & & \\
$\geq 0$ & & \\
$>0$ & 39,0 & 0.0 \\
$\geq 0,05$ & 66,7 & 74,6 \\
$\geq 0,1$ & 69.2 & 81,5 \\
$\geq 0,2$ & 75,0 & 67.9 \\
$\geq 0.3$ & 71,4 & 63.4 \\
$\geq 0,4$ & 66.7 & 61.9 \\
& 0.0 & 100,0
\end{tabular}

De hPL-bepaling is het meest betrouwbaar als een afkappunt van $\geq 0,05 \mathrm{mU} / \mathrm{g} . e$. wordt gebruikt. De sensitiviteit is dan $46,2 \%$, de specificiteit $86,9 \%$, de voorspellende waarde van een positieve test 69,2 en de voorspellende waarde van een negatieve test $81,5 \%$. 
hoofdstuk 6

\section{Conclusie}

Het gebruik van de hPL-concentratie per gram eiwit als diagnosticum bij dubieus gebroken vliezen heeft een lage sensitiviteit en een redelijke specificiteit bij een afkappunt van groter of gelijk aan $0,05 \mathrm{mU} /$ gram eiwit. 


\section{- Resultaten van het onderzoek}

\subsection{Glucose- en fructose-bepaling}

\subsubsection{Inleiding}

De bepaling van glucose en fructose als diagnosticum bij dubieus gebroken vliezen werd slechts eénmaal eerder beschreven (Gorodeski e.a. 1979). Deze onderzoekers gaan er van uit dat bij dubieus gebroken vliezen de diagnostiek wordt bemoeilijkt door cervixslijm. Daar cervixslijm veel meer glucose en fructose bevat dan vruchtwater (Kittrich e.a. 1965, Weed en Carrera 1970 en lacobelli e.a. 1971), hebben Gorodeski e.a. (1979) de diagnostische waarde onderzocht van glucose en fructose bij dubieus gebroken vliezen. Met behulp van de glucose- en fructose-concentratie was het voor Gorodeski e.a. mogelijk om bij dubieus gebroken vliezen, met een goede betrouwbaarheid staande vliezen van gebroken vliezen te onderscheiden. Het blijkt dat beide parameters elkaar potentiëren. Met behulp van een stapsgewijze discriminant analyse voor 2 parameters werd een formule gevonden: 3,32 log[concentratie glucose] + $\log$ [concentratie fructose] met een nog grotere betrouwbaarheid. Het onderzoek van Gorodeski bestaat uit 2 groepen patiënten: een groep met een klinisch zekere diagnose en een groep met een klinisch onduidelijke diagnose. 215 Patiënten waren bij het onderzoek betrokken; bij 26 patiënten was de diagnose niet zeker. De resultaten van Gorodeski e.a. (1979) zijn samengevat in tabel 85.

Tabel 85: Resultaten van het onderzoek van Gorodeski e.a. 1979.

\begin{tabular}{|c|c|c|c|}
\hline & $\begin{array}{l}\text { aantal patiënten } \\
\text { diagnose juist }\end{array}$ & $\begin{array}{l}\text { aantal patiënten } \\
\text { diagnose onjuist }\end{array}$ & $\begin{array}{l}\text { totaal aantal } \\
\text { patiënten }\end{array}$ \\
\hline \multicolumn{4}{|l|}{$\begin{array}{r}\text { diagnose zeker } \\
(n=189)\end{array}$} \\
\hline glucose & 180 & 9 & 189 \\
\hline fructose & 173 & 16 & 189 \\
\hline \multirow[t]{2}{*}{$3.32 \log$ glu. $+\log$ fruc. } & 184 & 5 & 189 \\
\hline & $\begin{array}{l}\text { aantal patiènten } \\
\text { diagnose juist }\end{array}$ & $\begin{array}{l}\text { aantal patiènten } \\
\text { diagnose onjuist }\end{array}$ & $\begin{array}{l}\text { totaal aantal } \\
\text { patiẻnten }\end{array}$ \\
\hline \multicolumn{4}{|l|}{$\begin{array}{r}\text { diagnose onzeker } \\
(n=26)\end{array}$} \\
\hline glucose & 22 & 4 & 26 \\
\hline fructose & 21 & 5 & 26 \\
\hline $3,32 \log$ glu. $+\log$ fruc. & 24 & 2 & 26 \\
\hline
\end{tabular}


hoofdstuk 6

Ondanks deze veelbelovende resultaten is het voorstel van de auteurs, glucose- en fructose-concentratie te gebruiken als diagnosticum bij dubieus gebroken vliezen, merkwaardigerwijs door niemand overgenomen. Gezien de door Gorodeski e.a. (1979) behaalde resultaten werd de glucose- en fructose-bepaling in het protocol van dit onderzoek opgenomen.

\subsubsection{Methode van glucose- en fructose-bepaling}

De methode van glucose-bepaling

Gebruikt werd de commercieel beschikbare glucose-bepaling van Boehringer: de Gluco-quanttest. Dit is een bepaling die gebaseerd is op de omzetting van glucose en ATP met behulp van het enzym hexokinase naar glucose-6-phosphaat en ADP.

Uit glucose-6-phosphaat wordt vervolgens met behulp van het enzym 6-phosphaatglucose-dehydrogenase het 6-phosphogluconzuur gevormd, waarbij NADH ontstaat, hetgeen spectrofotometrisch meetbaar is.

De methode van fructose-bepaling

Fructose werd bepaald met behulp van anthron. Bij deze bepaling wordt gebruik gemaakt van het gegeven dat fructose wordt gedehydreerd als het wordt verwarmd met een sterk zuur. Hierbij wordt hydroxymethylfurfural (HMF) gevormd en is de hoeveelheid die hiervan wordt gevormd een maat voor de fructoseconcentratie. Anthron reageert met HMF tot een gekleurd produkt dat colorimetrisch wordt gemeten zodat de fructoseconcentratie kan worden bepaald.

\subsubsection{Glucose-bepaling bij patiënten met een zekere diagnose}

In de groep met een zekere diagnose (eigenschappen van deze groep zijn beschreven in paragraaf 6.2) werd glucose bepaald in vruchtwater, serum en urine (tabel 86). 
Tabel 86: De gemiddelde glucose-concentratie (gem. conc.) \pm S.D. in vruchtwater (vrw.), serum en urine in de verschillende amenorroegroepen en het aantal uitgevoerde bepalingen.

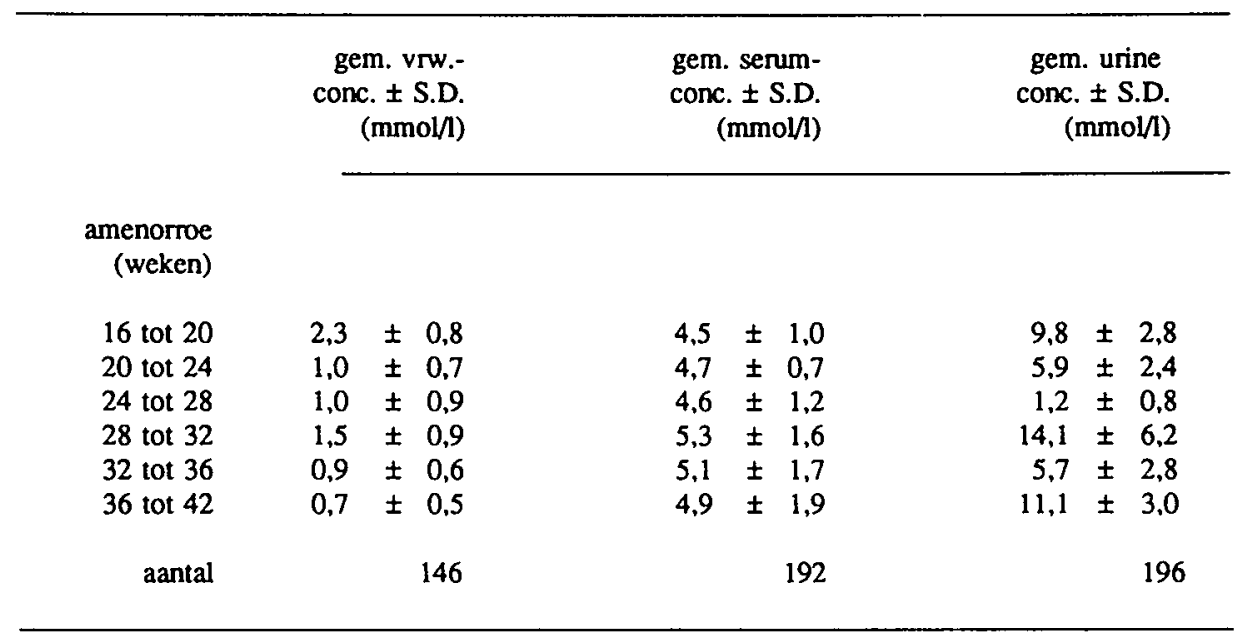

In tabel 86 is te zien dat de gemiddelde glucoseconcentratie in vruchtwater daalt met het vorderen van de amenorroeduur. De serumconcentratie blijft redelijk constant terwijl de urineconcentratie sterk wisselt. De waarden zijn in overeenstemming met literatuurgegevens (Kittrich e.a. 1965). De gevonden concentraties echter zijn niet in overeenstemming met de waarden van Gorodeski e.a. (1979).

De oorzaken hiervan kunnen zijn de andere wijze van afname (afname rechtstreeks uit de cervix) door Gorodeski e.a. (1979) en/of de extractiemethode van vruchtwater die door deze onderzoekers werd toegepast.

Om de concentraties van glucose in vruchtwater, serum en urine te kunnen vergelijken met die in fluor vaginalis en cervixslijm moeten de concentraties per gram eiwit worden berekend (er werd immers een extractie methode bij de bepaling van fluor vaginalis en cervixslijm toegepast, paragraaf 6.3). De concentraties per gram eiwit worden samengevat in tabel 87. 
hoofdstuk 6

Tabel 87: De gemiddelde glucose-concentratie (gem.conc.) per gram eiwit $\pm S . D$. in vruchtwater (vrw.), serum (ser.), fluor vaginalis (fluor) en cervixslijm (cerv. sl.) in de amenorroeklassen en het aantal uitgevoerde bepalingen.

\begin{tabular}{|c|c|c|c|c|}
\hline \multirow[b]{2}{*}{$\begin{array}{r}\text { amenorroc } \\
\text { (weken) }\end{array}$} & \multirow[t]{2}{*}{$\begin{array}{r}\text { gem. vrw.- } \\
\text { conc. } \pm \text { S.D. } \\
(\mathrm{mmol} / \mathrm{g} . \mathrm{e} .)\end{array}$} & \multirow[t]{2}{*}{$\begin{array}{r}\text { gem. ser.- } \\
\text { conc. } \pm \text { S.D. } \\
(\mathrm{mmol} / \mathrm{g} . \mathrm{e} .)\end{array}$} & \multirow[t]{2}{*}{$\begin{array}{r}\text { gem. fluor- } \\
\text { conc. } \pm \text { S.D. } \\
\text { (mmol/g.e.) }\end{array}$} & $\begin{array}{r}\text { gem. cerv. sl. } \\
\text { conc. } \pm \text { S.D. } \\
\text { (mmol/g.e.) }\end{array}$ \\
\hline & & & & \\
\hline 16 tot 20 & $0,5 \pm 0,3$ & $0,07 \pm 0,02$ & $3.8 \pm 4.8$ & $0.4 \pm$ \\
\hline 20 tot 24 & $0.2 \pm 0.2$ & $0.07 \pm 0,01$ & $3,1 \pm 3,2$ & - \pm \\
\hline 24 tot 28 & $0.2 \pm 0.2$ & $0,07 \pm 0,02$ & $0.7 \pm 0.1$ & $-t$ \\
\hline 28 tot 32 & $0,3 \pm 0,3$ & $0,09 \pm 0,03$ & $5.0 \pm 5.5$ & - \pm \\
\hline 32 tot 36 & $0.3 \pm 0.2$ & $0.09 \pm 0.03$ & $6.7 \pm 5.0$ & $0.6 \pm$ \\
\hline 36 tot 42 & $0.3 \pm 0.2$ & $0.09 \pm 0.03$ & $1.9 \pm 2.0$ & $0.6 \pm 0.5$ \\
\hline aantal & 127 & 126 & 56 & 14 \\
\hline
\end{tabular}

Tabel 87 laat zien dat de gemiddelde concentratie van glucose per gram eiwit in vruchtwater redelijk constant is en minstens tweemaal zo hoog is als die in serum. De urineconcentratie van glucose, uitgedrukt per gram eiwit, is niet weergegeven daar urine met de voor dit onderzoek gebruikte bepalingsmethode meestal geen detecteerbare hoeveelheden eiwit bevat. Daar urine wel glucose bevat kan bijmenging van urine bij vaginaal afgelopen vloeistof, de concentratie van glucose per gram eiwit doen toenemen. Bloedbijmenging bij fluor vaginalis zal nauwelijks invloed hebben.

De gemiddelde glucose-concentratie per gram eiwit in fluor vaginalis is hoger dan de glucose-concentratie per gram eiwit in vruchtwater en vertoont een grote variatie. De cervixslijm-concentratie per gram eiwit, zoals in dit onderzoek wordt gevonden, is laag. Deze waarden zijn niet vergelijkbaar met literatuurgegevens daar de glucose concentraties berekend zijn per gram eiwit.

In semen was glucose aantoonbaar. De concentratie varieert van 5,7 tot $7,9 \mathrm{mmol} / \mathrm{l}$. Daar semen een hoge concentratie eiwit $(>50 \mathrm{~g} / \mathrm{h})$ heeft zal semen-bijmenging nauwelijks een negatieve invloed hebben bij het gebruik van de glucose-bepaling als diagnosticum bij dubieus gebroken vliezen.

Om de afkappunten te kunnen vaststellen is een frequentieverdeling gebruikt (tabel 88). 
Tabel 88: Frequentieverdeling van de concentraties van glucose per gram eiwit in vruchtwater (vrw.), serum. urine, fluor vaginalis (fuor) en cervixslijm (cervixsl.) en het aantal uitgevoerde bepalingen.

\begin{tabular}{|c|c|c|c|c|c|}
\hline & $\begin{array}{c}\text { aantal } \\
\text { vrw. }\end{array}$ & $\begin{array}{l}\text { aantal } \\
\text { serum }\end{array}$ & $\begin{array}{c}\text { aantal } \\
\text { urine }\end{array}$ & $\begin{array}{r}\text { aantal } \\
\text { fluor }\end{array}$ & $\begin{array}{r}\text { aantal } \\
\text { cervixsl. }\end{array}$ \\
\hline \multicolumn{6}{|l|}{$\begin{array}{c}\text { concentratie } \\
\text { (mmol/g.e.) }\end{array}$} \\
\hline 0 & 7 & 0 & 0 & 1 & 0 \\
\hline$>0$ en $<0.2$ & 51 & 124 & 3 & 2 & 3 \\
\hline 20,2 en $<0,4$ & 40 & 2 & 3 & 5 & 5 \\
\hline$\geq 0,4$ en $<0,6$ & 16 & 0 & 1 & 3 & 1 \\
\hline$\geq 0.6$ en $<0,8$ & 9 & 0 & 1 & 5 & 0 \\
\hline$\geq 0,8$ en $<1,0$ & 4 & 0 & 0 & 2 & 2 \\
\hline$\geq 1,0$ en $<1,2$ & 0 & 0 & 1 & 1 & 1 \\
\hline 21,2 & 0 & 0 & 189 & 37 & 2 \\
\hline aantal & 127 & 126 & 198 & 56 & 14 \\
\hline
\end{tabular}

In tabel 88 is te zien dat de vruchtwater-concentraties van glucose per gram eiwit liggen tussen de 0 en $1 \mathrm{mmol} / \mathrm{gram}$ eiwit. De afkappunten zijn: $\geq 0,>0$ en $<1 \geq 0,1$ en $<1, \geq 0,2$ en $<1, \geq 0,3$ en $<1, \geq 0,4$ en $<1 \mathrm{mmol} /$ gram eiwit.

\section{Conclusies}

1. Urine en fluor vaginalis kunnen de glucose-bepaling als diagnosticum bij dubieus gebroken vliezen negatief beïnvloeden.

2. Bij het gebruik van de glucose-concentratie per gram eiwit als diagnosticum bij dubieus gebroken vliezen dienen afkappunten te worden gebruikt tussen de 0 en $1 \mathrm{mmol} / \mathrm{gram}$ eiwit.

\subsubsection{Glucose-bepaling bij patiënten met dubieus gebroken vliezen}

In vaginaal afgelopen vocht, dat was verzameld bij 100 patiënten met dubieus gebroken vliezen, werd de glucose-concentratie per gram eiwit bepaald. De amenorroeduur van de patiënten en de eiwitconcentratie van deze vloeistoffen zijn vermeld in paragraaf 6.2 en 6.3. De sensitiviteit en specificiteit zijn zichtbaar in figuur 23. De afkappunten zijn beschreven in paragraaf 6.13 .3 . 
hoofdstuk 6

Figuur 23: ROC-curve van de glucoseconcentratie per gram eiwit in vaginaal afgelopen vocht met de afkappunten: $\geq 0,>0$ en $<1, \geq 0,1$ en $<1, \geq 0,2$ en $<1, \geq 0,3$ en $<1, \geq 0,4$ en $<1$ mmollg.e..

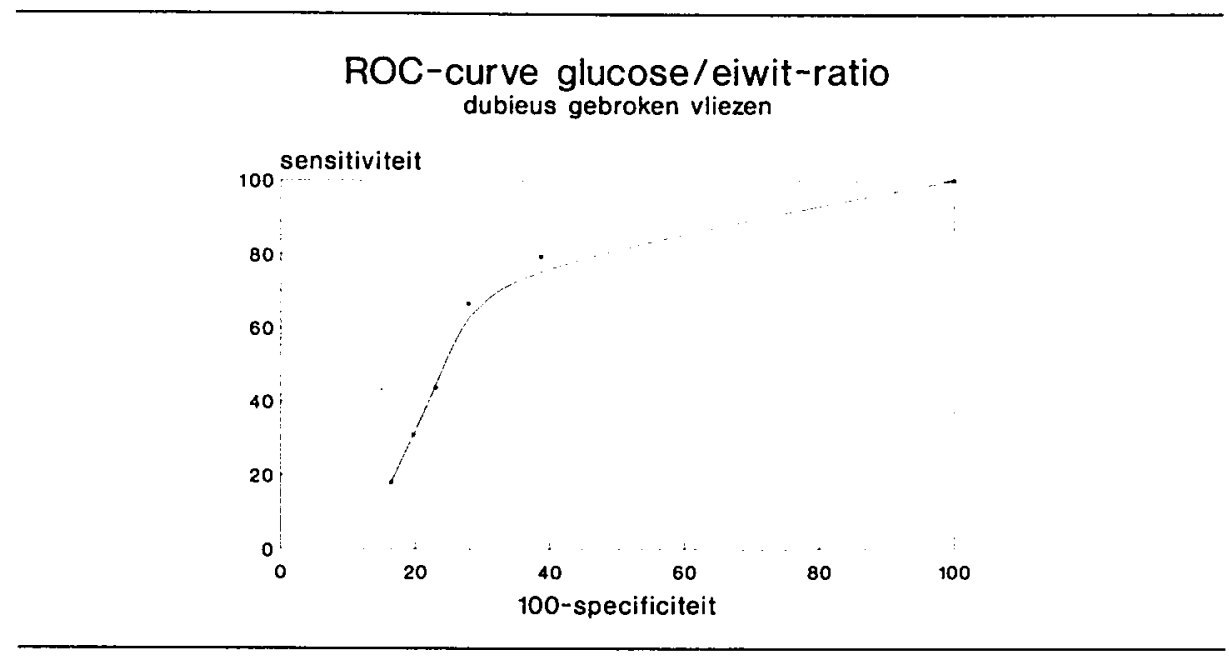

Redelijk voorspellende waarden van een positieve test en van een negatieve test worden gevonden in een gebied met als afkappunten: $>0$ en $<1$ en $\geq 0,1$ en $<1$. De percentages worden gegeven in tabel 89.

Tabel 89: Sensitiviteit, specificiteit en voorspellende (voorsp.) waarde van een positieve respectievelijk negatieve test van de glucoseconcentratie per gram eiwit bij dubieus gebroken vliezen bij verschillende afkappunten.

\begin{tabular}{rrrrr}
\hline & $\begin{array}{r}\text { sensiti- } \\
\text { viteit (\%) }\end{array}$ & $\begin{array}{r}\text { specifi- } \\
\text { citeit (\%) }\end{array}$ & $\begin{array}{r}\text { voorsp. waarde } \\
\text { positieve test (\%) }\end{array}$ & $\begin{array}{r}\text { voorsp. waarde } \\
\text { negatieve test (\%) }\end{array}$ \\
\cline { 2 - 5 } afkappunt \\
(mmol/g.e.) & & & & \\
& & & & \\
$>0$ en $<1$ & 79,5 & 61.3 & 57.4 & 77.6 \\
$\geq 0.1$ en $<1$ & 66.7 & 72,1 & 60.5 & \\
\hline
\end{tabular}

\section{Conclusie}

Indien de glucosebepaling wordt gebruikt als diagnosticum bij dubieus gebroken vliezen wordt een redelijke sensitiviteit en specificiteit gevonden bij afkappunten van $>0$ en $<1 \mathrm{mmol} / \mathrm{g}$.e. of van $\geq 0,1$ en $<1 \mathrm{mmol} / \mathrm{g}$.e.. 


\subsubsection{Fructose-bepaling bij patiënten met een zekere diagnose}

Ook fructose werd bepaald in de vloeistoffen die werden verzameld bij patiënten met een zekere diagnose. Het aantal patiënten en de amenorroeduur is vermeld in paragraaf 6.2. De gemiddelde waarden van fructose in vruchtwater en urine met de standaard-deviatie in de amenorroeklassen zijn vermeld in tabel 90.

Tabel 90: Gemiddelde fructose-concentratie (gem.conc.) \pm S.D. in vruchtwater (vrw.) en urine bij de verschillende amenorroeklassen en het aantal uitgevoerde bepalingen.

$\begin{array}{ll}\text { gem. vrw.-conc. } & \text { gem. urine-conc. } \\ \pm \text { S.D. }(\mathrm{mmol} / \mathrm{l}) & \pm \text { S.D. (mmol/l) }\end{array}$

amenorroe

(weken)

16 tot 20

20 tot 24

24 tot 28

28 tot 32

32 tot 36

36 tot 42

aantal
$0,13 \pm 0,08$

$0,11 \pm 0,12$

$0,06 \pm 0,05$

$0,13 \pm 0,10$

$0,08 \pm 0,05$

$0,11 \pm 0,08$

146

$$
\begin{aligned}
& 1,29 \pm 0,64 \\
& 0,86 \pm 0.38 \\
& 1,40 \pm 1,36 \\
& 1,29 \pm 0,80 \\
& 1,39 \pm 1,03 \\
& 1,18 \pm 0,78
\end{aligned}
$$

198

De gemiddelde fructose-concentratie in vaginaal afgelopen vruchtwater is redelijk constant (tabel 90). De gemiddelde fructose-concentratie in urine is groter dan die in vaginaal afgelopen vruchtwater. Serum bevat geen fructose.

Om de concentraties te kunnen vergelijken met fluor vaginalis en cervixslijm werd ook hier de concentratie berekend per gram eiwit. De resultaten zijn vermeld in tabel 91. 
hoofdstuk 6

Tabel 91: Gemiddelde fructose-concentratie (gem. conc.) per gram eiwit $\pm S . D$. in vruchnvater (vrw.), fluor vaginalis (fluor) en cervixslijm (cerv.sl.) bij de amenorroeklassen en het aantal uitgevoerde bepalingen.

\begin{tabular}{|c|c|c|c|}
\hline & $\begin{array}{c}\text { gem. vrw.- } \\
\text { conc. } \pm \text { S.D. } \\
\text { (mmol/g.e.) }\end{array}$ & $\begin{array}{l}\text { gem. fluor- } \\
\text { conc. } \pm \text { S.D. } \\
\text { (mmol/g.e.) }\end{array}$ & $\begin{array}{l}\text { gem. cerv.sl.- } \\
\text { conc. } \pm \text { S.D. } \\
(\mathrm{mmol} / \mathrm{g} . \mathrm{e} .)\end{array}$ \\
\hline \multicolumn{4}{|l|}{$\begin{array}{r}\text { amenorroe } \\
\text { (weken) }\end{array}$} \\
\hline 16 tot 20 & $0,026 \pm 0,014$ & $0.297 \pm 0,232$ & $0,02 \pm-$ \\
\hline $20 \operatorname{tot} 24$ & $0,018 \pm 0,016$ & $0,209 \pm 0,210$ & - \pm \\
\hline 24 tot 28 & $0,010 \pm 0,008$ & $0.192 \pm 0.072$ & - \pm \\
\hline 28 tot 32 & $0,022 \pm 0,007$ & $0,240 \pm 0,140$ &.- \pm \\
\hline 32 tot 36 & $0,029 \pm 0,019$ & $0,324 \pm 0,294$ & $0,023 \pm$ \\
\hline $36 \operatorname{tot} 42$ & $0,041 \pm 0,032$ & $0.087 \pm 0.065$ & $0,040 \pm 0,043$ \\
\hline aantal & 127 & 56 & 14 \\
\hline
\end{tabular}

Uit tabel 91 blijkt dat de fructose-concentratie in vruchtwater per gram eiwit laag is. De urineconcentraties zijn ook hier niet weergegeven daar urine met de in dit onderzoek gebruikte bepalingsmethode zelden eiwit bevat. Daar urine wel fructose bevat kan bijmenging van urine, bij vaginaal afgelopen vloeistof, de concentratie per gram eiwit doen toenemen.

Uit tabel 91 blijkt ook dat de gemiddelde fructose-concentratie van fluor vaginalis, uitgedrukt per gram eiwit, hoger is dan die in vruchtwater. De concentratie van fructose in cervixslijm is evenwel vergelijkbaar met die in vruchtwater.

In het semen van 5 fertiele mannen wordt zoals verwacht fructose aangetroffen. De laagste concentratie was $20 \mathrm{mmol} / \mathrm{l}$ en de hoogste $28 \mathrm{mmol} / \mathrm{l}$. De eiwit-concentratie is ongeveer $50 \mathrm{~g} / \mathrm{l}$; derhalve is de fructose-concentratie van semen uitgedrukt per gram eiwit vergelijkbaar met die van fluor vaginalis.

Om de afkappunten vast te kunnen stellen is in tabel 92 de frequentieverdeling van de fructose-concentratie weergegeven. 
Tabel 92: Frequentieverdeling van de concentraties fructose per gram eiwit in vruchtwater, urine, fluor vaginalis (fuor) en cervixslijm en het aantal uitgevoerde bepalingen.

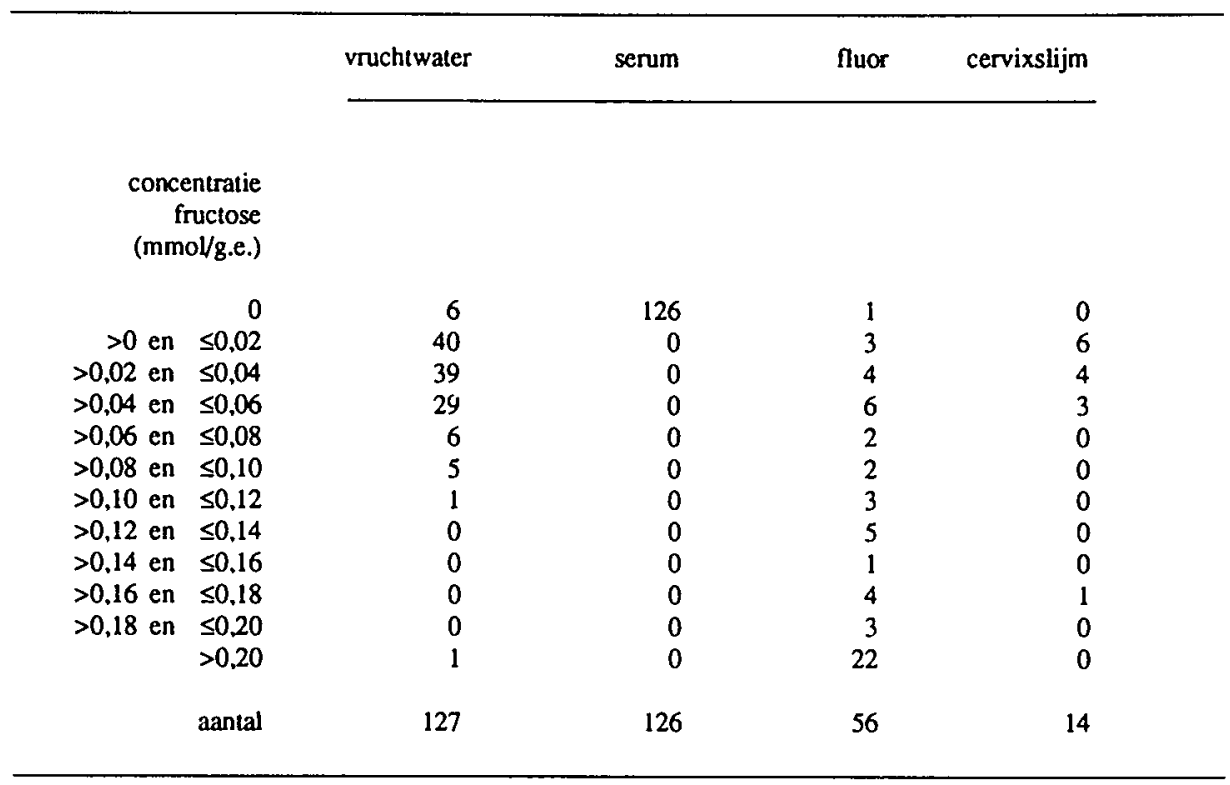

Uit deze frequentieverdeling (tabel 92) is te zien dat de fructose-concentratie per gram eiwit in vruchtwater meestal ligt tussen 0 en $0,12 \mathrm{mmol} / \mathrm{gram}$ eiwit. Als afkappunten werden gekozen: $\geq 0,>0$ en $<0,12, \geq 0,02$ en $<0,12, \geq 0,04$ en $<0,12, \geq 0,06$ en $<0,12$, $\geq 0,08$ en $<0,12$.

Verder is ook te zien dat fluor vaginalis en cervixslijm de betrouwbaarheid van de fructosebepaling als diagnosticum bij dubieus gebroken vliezen negatief kunnen beïnvloeden.

Ook semen zal de diagnostiek negatief beïnvloeden.

\section{Conclusies}

1. Fluor vaginalis, cervixslijm en semen kunnen de bepaling van fructose, als diagnosticum bij dubieus gebroken vliezen, negatief beïnvloeden.

2. Indien de fructose-bepaling wordt gebruikt als diagnosticum bij dubieus gebroken vliezen komen afkappunten tussen 0 en $0,12 \mathrm{mmol} / \mathrm{gram}$ eiwit in aanmerking. 
hoofdstuk 6

\subsubsection{Fructose-bepaling bij patiënten met dubieus gebroken vliezen}

De sensitiviteit en specificiteit werd berekend en weergegeven in figuur 24 als ROC-curve. De afkappunten die werden gebruikt zijn vermeld in paragraaf 6.13.5.

Figuur 24: ROC-curve van de fructoseconcentratie per gram eiwit. Als afkappunten werden gekozen: $0 .>0$ en $<0,12, \geq 0,02$ en $<0,12,20,04$ en $<0,12, \geq 0,06$ en $<0,12, \geq 0,08$ en $<0,12$.

ROC-curve fructose/eiwit-ratio

dubieus gebroken vliezen

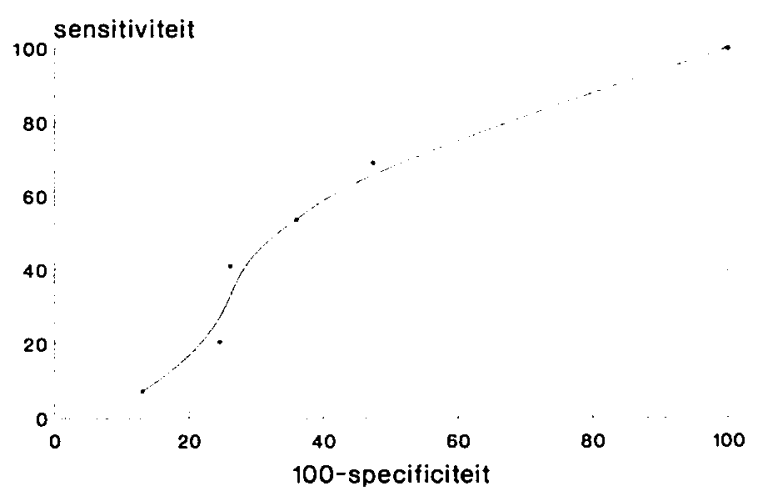

De betrouwbaarheid van de test is het grootst in het gebied met als afkappunten: $>0$ en $<0,12$ of $\geq 0,02$ en $<0,12 \mathrm{mmol} / \mathrm{g}$.e.: tabel 93 .

Tabel 93: De sensitiviteit, specificiteil en voorspellende (voorsp.) waarde van een positieve (pos.) respectievelijk negatieve (neg.) test bij de gegeven afkappunten van de frucloseconcentratie per gram eiwit.

\begin{tabular}{rrrrr}
\hline & $\begin{array}{r}\text { sensiti- } \\
\text { viteit (\%) }\end{array}$ & $\begin{array}{r}\text { specifi- } \\
\text { citeit (\%) }\end{array}$ & $\begin{array}{r}\text { voorsp. waarde } \\
\text { pos. test (\%) }\end{array}$ & $\begin{array}{r}\text { voorsp. waarde } \\
\text { neg. test (\%) }\end{array}$ \\
\cline { 2 - 4 } afkappunt & & & & \\
$(\mathrm{mmol} / \mathrm{g} . \mathrm{e})$. & & & & \\
& & & & \\
$>0$ en $<0,12$ & 69.2 & 42,6 & 43,5 & 68,4 \\
$\geq 0,2$ en $<0.12$ & 53,8 & 63,9 & 63,6 & 68.4 \\
\hline
\end{tabular}


diagnostiek

\section{Conclusie}

1. Als afkappunten, bij het gebruik van de fructoseconcentratie per gram eiwit als diagnosticum bij dubieus gebroken vliezen, moeten worden gebruikt: $>0$ of $\geq 0,02$ $\mathrm{mmol} / \mathrm{g}$.e. en steeds kleiner dan $0,12 \mathrm{mmol} / \mathrm{g} . e$. .

2. De betrouwbaarheid van de fructoseconcentratie bij dubieus gebroken vliezen is matig te noemen.

\subsubsection{Combinatie van de glucose- en fructosebepaling}

In navolging van Gorodeski e.a. (1979) werd met behulp van een logistisch regressiemethode (programma B.M.D.P.) de glucose- en fructose-bepaling per gram eiwit gecombineerd als diagnosticum bij dubieus gebroken vliezen. Dit leverde geen hogere sensitiviteit of specificiteit op. De fructose-bepaling per gram eiwit leverde geen essentiële bijdrage aan de gecombineerde bepaling ten opzichte van enkel de glucose-bepaling per gram eiwit.

De uitkomsten van de formule van Gorodeski leverde een zodanige wolk van punten op dat tussen patiënten met staande en gebroken vliezen niet gedifferentieerd kon worden.

\section{Conclusie}

De gecombineerde glucose- en fructose-bepaling is een matig diagnosticum om gebroken vliezen aan te tonen. De gegevens in de literatuur hieromtrent kunnen niet worden onderschreven.

\section{Discussie}

De in de literatuur meest gebruikte methoden om gebroken vliezen aan te tonen zijn de varentest en de $\mathrm{pH}$-bepaling. De hoge betrouwbaarheid van deze tests die worden beschreven kunnen in dit onderzoek niet worden bevestigd. De oorzaak van dit verschil moet worden gezocht in de samenstelling van de patiëntengroepen waarbij het onderzoek werd verricht. In de literatuur werd steeds gebruik gemaakt van slechts twee groepen, een groep waarbij de vliezen zeker zijn gebroken en een groep waarbij de vliezen zeker staan. In dit onderzoek wordt de betrouwbaarheid tevens bepaald in een groep waarbij niet duidelijk is of de vliezen staan dan wel zijn gebroken. 
hoofdstuk 6

$\mathrm{Na}$ afloop van de zwangerschap, en nàdat de bepalingen waren verricht, kon veelal (100 van de 120) met zekerheid (de gouden standaard) worden bepaald of de vliezen waren gebroken geweest of hadden gestaan.

Het soort vocht dat in de groep met dubieus gebroken vliezen ter beschikking is, is minder makkelijk te verwerken omdat het bestaat uit of verontreinigd is met een viskeuze substantie.

Wat het aantal bepalingen en het aantal te onderzoeken soorten vocht betreft speelden de volgende factoren een ongunstige rol.

- Er werd geprobeerd om bij alle patiënten met een bekende diagnose zoveel mogelijk soorten vocht te verzamelen, voor cervixslijm bleek dit de meeste problemen op te leveren (slechts 18 monsters).

- Per monster werd steeds als laatste de hoeveelheid eiwit bepaald. Helaas was niet altijd voldoende vocht meer beschikbaar om deze bepaling uit te voeren. Bij de eiwitbepalingen zijn de patiënten die veel vocht verloren in sterkere mate vertegenwoordigd. 


\section{Hoofdstuk 7}

\section{Combinaties van bepalingsmethoden}

Het ligt voor de hand te onderzoeken of combinaties van methoden, om gebroken vliezen aan te tonen, betere resultaten opleveren dan de verschillende methoden op zich. Toch is geen goed onderzoek in de literatuur te vinden dat de betrouwbaarheid weergeeft van combinaties van diagnostische mogelijkheden om gebroken vliezen aan te tonen. Wel hebben onderzoekers die het effect van het vroegtijdig breken van de vliezen bestudeerden gebruik gemaakt van combinaties van verschillende diagnostische mogelijkheden om gebroken vliezen aan te tonen (bijvoorbeeld: Fayez e.a. 1978, Varner en Galask 1981, Berkowitz e.a. 1982, Wilson e.a. 1982, Duff 1984). Een bekende combinatie is: anamnese, varentest, $\mathrm{pH}$ en onderzoek in speculo.

Gekozen werd in dit onderzoek voor toetsing door middel van een logistisch regressiemodel (statistisch programma B.M.D.P.). Deze methode heeft het voordeel dat zowel kwantitatieve als kwalitatieve gegevens kunnen worden gebruikt en de kans op het aanwezig zijn van gebroken vliezen kan worden berekend uit anamnestische gegevens van een patiënte en in het bijzonder met behulp van uitslagen van diagnostische tests.

De uitslagen van alle gebruikte diagnostische tests van 100 patiënten met dubieus gebroken vliezen werden bewerkt, met het statistische pakket "B.M.D.P.". Als extra factoren werden toegevoegd amenorroeduur, geslacht, aantal graviditeiten en percentiel van het geboortegewicht van het kind.

Bij stapsgewijze analyse bleek dat de hoogste sensitiviteit en specificiteit was te bereiken met de combinatie van: Nile-blue-sulfaat-test, glucosebepaling, prolactine/eiwit-ratio en amenorroeduur, bij het eerder gedefinieerde optimale afkappunt (hoofdstuk 6). De sensitiviteit is dan $87,2 \%$ en de specificiteit $98,4 \%$. Als dit resultaat, de combinatie van 4 diagnostische mogelijkheden, wordt vergeleken met de betrouwbaarheid van de prolactine-bepaling alleen (sensitiviteit $87,2 \%$ en specificiteit $91,8 \%$ ) dan is het duidelijk dat door het uitvoeren van meer bepalingen de betrouw-baarheid van de diagnostiek maar weinig wordt verbeterd ten opzichte van de prolactinebepaling alleen. De sensitiviteit komt zelfs geheel voor "rekening" van de prolactinebepaling.

\section{Conclusie}

Combinatie van diagnostische mogelijkheden om het staan of het gebroken zijn van de vliezen aan te tonen verhogen de betrouwbaarheid niet wezenlijk ten opzichte van de prolactine-bepaling alleen. 


\section{Hoofdstuk 8}

\section{Algemene discussie}

Uiteraard is het niet zo dat het altijd een probleem is om de diagnose gebroken vliezen te stellen: een à terme zwangere patiënte die onwillekeurig vocht verliest en als bij onderzoek veel aflopend vocht uit de cervix wordt gezien zal ongetwijfeld gebroken vliezen hebben. Er zijn echter patiënten, en ons onderzoek richt zich hierop, die maar weinig vocht verliezen; het bevestigen van het staan of het gebroken zijn van de vliezen is dan veel moeilijker. Zeker als vochtverlies optreedt in de immature of vroeg premature fase van de zwangerschap is het stellen van de juiste diagnose van groot belang. Invasief onderzoek, zoals een onderzoek in speculo, is dan niet gewenst. Hoe vaak het moeilijk is om de diagnose gebroken vliezen te stellen was niet bekend. Het blijkt een frequent voorkomend probleem te zijn: bij ongeveer $5 \%$ van de zwangere patiënten wordt gedurende de zwangerschap getwijfeld aan het staan van de vliezen. Dit twijfelen bleek nadelig te zijn voor zowel moeder als kind: de moeder bleek significant vaker een gecompliceerd kraambed te hebben en verbleef langer in het ziekenhuis gedurende het kraambed, het kind werd vaker opgenomen op de couveuzeafdeling en werd daardoor vaker van de moeder gescheiden. Merkwaardigerwijs werd wetenschappelijk onderzoek van testmethoden om het verlies van vruchtwater aan te tonen vooral vóór 1980 verricht. Na 1980 werd wel onderzoek verricht naar de gevolgen van het langdurig gebroken zijn van de vliezen, maar werd nauwelijks gepubliceerd over de betrouwbaarheid van testmethoden, alsof dit probleem zou zijn opgelost. De mogelijkheden om betrouwbare bepalingen in kleine hoeveelheden vocht uit te voeren zijn daarentegen in de tachtiger jaren juist toegenomen. Het is daarbij opvallend dat in publikaties melding wordt gemaakt van de beperkte betrouwbaarheid van de tests om gebroken vliezen aan te tonen en dat tezelfder tijd groepen patiënten worden vergeleken die op basis van deze tests zijn onderscheiden. Dat het verwaarlozen van onderzoek naar betrouwbare testmethoden ten onrechte is wordt verder ondersteund doordat velen ervan zijn overtuigd dat langdurig gebroken vliezen (langer dan 24 uur) een ernstige obstetrische complicatie is. De noodzaak voor het hier beschreven onderzoek moge dan ook duidelijk zijn.

Het leek derhalve van belang een methode te zoeken waarmee het mogelijk is met zekerheid vruchtwater aan te tonen in kleine hoeveelheden vaginaal afgelopen vocht zonder dat het onderzoek op zich schadelijk is. In totaal werden 11 parameters om gebroken vliezen aan te tonen in het onderzoek betrokken. Daar vocht verkregen bij patiënten met dubieus gebroken vliezen vaak viskeus is werd een extractiemethode toegepast en werden de concentraties berekend per gram eiwit. Dit bleek een groot voordeel daar bloedbijmenging de betrouwbaarheid van de meeste bepalingen negatief beïnvloedt. Bloed bevat veel eiwit; door de concentratie per gram eiwit te berekenen neemt de betrouwbaarheid van de meeste bepalingen als diagnosticum bị gebroken 
hoofdstuk 8

vliezen toe. De bepaling van prolactine per gram eiwit bleek een adequaat diagnosticum bij dubieus gebroken vliezen te zijn. De betrouwbaarheid van alle andere methoden kan op zijn best "matig" genoemd worden.

Alle "klassieke" bepalingen, zoals varentest, pH en Nile-blue-sulfaat-test zijn verre inferieur aan de prolactine-bepaling. Combinaties van verschillende bepalingen gaven geen verbetering ten opzichte van de prolactine-bepaling alleen.

De prolactine/eiwit-ratio is echter een bepaling die veel tijd in beslag neemt, ongeveer 2 uur, en kan bovendien alleen in een goed uitgerust ziekenhuislaboratorium worden uitgevoerd. Dit is voor de praktijk met name in de eerste lijns-geneeskunde een groot nadeel. Een snellere bepaling van de prolactine/eiwit-ratio kan de oplossing van het twijfelen aan het gebroken zijn van de vliezen betekenen; de mogelijkheden daartoe zijn aanwezig (monoclonale antilichamen) maar zullen eerst op hun betrouwbaarheid moeten worden beoordeeld. 


\section{Samenvatting}

Vraagstelling en opzet van het onderzoek wordt in hoofdstuk 1 uiteengezet: hoe vaak wordt aan de diagnose gebroken vliezen getwijfeld; zijn aan die twijfel nadelen verbonden en kan de twijfel worden voorkómen.

In het eerste gedeelte van hoofdstuk 2 worden de oorzaken van voortijdig gebroken vliezen besproken. Het breken van de vliezen is een complex geheel en multifactorieel bepaald.

Hoofdstuk 2 beschrijft ook de incidentie en complicaties van voortijdig gebroken vliezen. De incidentie van voortijdig gebroken vliezen wordt in literatuur opgegeven als $10 \%$.

De complicaties die op kunnen treden worden met name bepaald door het moment waarop de vliezen tijdens de zwangerschap breken: van 16 tot 28 weken wordt de foetus vooral bedreigd door onrijpheid, van 28 tot 37 weken zijn de belangrijkste complicaties infecties, R.D.S. en longhypoplasie en vanaf 37 weken is het ontstaan van een infectie de belangrijkste complicatie.

Het laatste gedeelte van hoofdstuk 2 geeft een overzicht van de diagnostische mogelijkheden die in de literatuur worden genoemd.

Er kunnen 4 soorten diagnostiek worden onderscheiden om gebroken vliezen aan te tonen: subjectieve, objectieve, invasieve en overige diagnostische mogelijkheden. Met behulp van literatuurgegevens wordt geconstateerd dat de beste methode objectief, redelijk betrouwbaar en niet-invasief moet zijn.

Hoofdstuk 3 vermeldt de resultaten van een enquête in drie Zuidlimburgse klinieken. De bedoeling was inzicht te krijgen in de omvang van het probleem "twijfel aan het staan van de vliezen". In 1 jaar tijd werd in de drie klinieken bij 166 patiënten getwijfeld aan het staan van de vliezen, dit bij een totaal van 2903 bevallingen.

In hoofdstuk 4 worden de Nederlandse gegevens van patiënten met kortdurend $(\leq 24$ uur) en langdurig ( $>24$ uur) gebroken vliezen vergeleken. Met behulp van gegevens verkregen van de Stichting Informatie-centrum Gezondheidszorg (S.I.G.) is het mogelijk om de complicaties van langdurig gebroken vliezen te inventariseren. De groep met langdurig gebroken vliezen bestond uit 3870 patiënten; de groep met kortdurend gebroken vliezen uit 3799 patiënten. Het voortijdig breken van de vliezen, gedefinieerd als het breken van de vliezen voordat weeënactiviteit optreedt, komt frequent voor. In deze groep is het zeer gewenst om het gebroken zijn van de vliezen met zekerheid te kunnen aantonen. Tevens is de conclusie dat de conditie van het kind wordt beïnvloed door het langdurig gebroken zijn van de vliezen. 
samenvatting

In de groep met langdurig gebroken vliezen worden moeder en kind vaker van elkaar gescheiden na de geboorte van het kind. Ook verblijft de moeder langer in het ziekenhuis in vergelijking met moeders uit de groep met kortdurend gebroken vliezen.

Uiteraard is er een essentieel verschil tussen langdurig en dubieus gebroken vliezen. Daarom wordt in hoofdstuk 5 de morbiditeit en mortaliteit bij dubieus gebroken vliezen vergeleken met groepen zwangeren met kortdurend respectievelijk langdurig gebroken vliezen. Hiervoor werd de enquêtegroep en de groep met dubieus gebroken vliezen samengevoegd $(n=273)$. Geconcludeerd wordt dat de groep patiënten waarbij aan het staan van de vliezen wordt getwijfeld eerder vergelijkbaar is met de groep met langdurig gebroken vliezen dan met de groep met kortdurend gebroken vliezen. Met name komen complicaties vaker voor bij moeders waarbij werd getwijfeld aan het gebroken zijn van de vliezen tijdens de zwangerschap dan bij moeders met langdurig respectievelijk kortdurend gebroken vliezen.

Hoofdstuk 6 is gewijd aan een betrouwbaarheidsonderzoek van diagnostische methoden om gebroken vliezen aan te tonen. Allereerst werd bij een groep van 203 patiënten, waarbij de diagnose staande dan wel gebroken vliezen zeker was, vruchtwater, serum, urine, fluor vaginalis en cervixslijm verzameld. In deze vloeistoffen werden 11 parameters bepaald. In het semen van 5 fertiele mannen werden dezelfde bepalingen uitgevoerd. Met behulp van de verkregen resultaten, de "normaalwaarden" van deze diagnostische mogelijkheden bij gebroken en bij niet gebroken vliezen, werd onderzocht of ze bruikbaar zouden kunnen zijn als diagnosticum bij dubieus gebroken vliezen. Reeds tijdens de voorbereidingen van het onderzoek was het duidelijk dat bepalingen in fluor vaginalis, cervixslijm en vocht, verkregen bij patiënten met dubieus gebroken vliezen, niet rechtstreeks mogelijk zijn. De consistentie is zodanig dat eerst extractie nodig is. Het protocol dat hiervoor werd gevolgd wordt beschreven in hoofdstuk 6.

Extractie had verder als voordeel dat maar weinig vocht $(0,1 \mathrm{cc})$ nodig was om betrouwbare bepalingen te kunnen uitvoeren. $\mathrm{Bij}$ extracties is het gebruikelijk om niet alleen de oorspronkelijke concentratie te bepalen, maar de concentratie te berekenen per gram eiwit in de vloeistof.

Bloedbijmenging bleek negatief te interfereren met de betrouwbaarheid van de meeste bepalingen zónder extractie. Daar bloed een hoge concentratie eiwit bevat wordt de concentratie van een aantal stoffen in het bloed "geëliminineerd" door de berekening van de concentratie per gram eiwit. Geconcludeerd wordt dat de prolactine-concentratie per gram eiwit het beste en een goed diagnosticum is om gebroken vliezen aan te tonen.

In hoofdstuk 7 wordt de combinatie van diagnostica bij dubieus gebroken vliezen beschreven. Combinatie van parameters ten opzichte van de prolactinebepaling alleen om gebroken vliezen aan te tonen, verhoogt de betrouwbaarheid niet. 
Hoofdstuk 8 geeft een overzicht van de mogelijkheden die nu beschikbaar zijn om de met de grootst mogelijke zekerheid de diagnose gebroken vliezen te stellen.

Er wordt ook ingegaan op de ontwikkelingen die zich in de toekomst mogelijk zullen voordoen om de diagnostiek een eenvoudige en bereikbare techniek te laten worden. 


\section{Summary}

The objectives of the present study are described in chapter 1 and can be summarized as follows:

1 How often in a population of pregnant women with suspect vaginal fluid loss, is the outcome of the routine diagnostic procedures inconclusive with respect to the state of the membranes?

2 Has this lack of support in these cases a negative impact on subsequent management and prognosis of mother and/or infant?

3 If so, is it possible to improve the efficacy in diagnosing "ruptured membranes"?

Prevalence, etiology and complications of Premature Rupture of the Membranes (PROM) are discussed in the first part of chapter 2. PROM occurs in approximately $10 \%$ of all pregnancies. PROM appears to complicate pregnancy, when a number of phenomena coincide. However, inasmuch the independent role of each of these phenomena is not clear, the understanding of the pathophysiologic mechanisms of PROM is still incomplete. Complications are in the first place determined by the gestational age. They include neonatal prematurity (before week 28), infection and lung hypoplasia (between weeks 28 and 37), and infection (after week 37).

In the last part of chapter 2 the clinical and laboratory options to diagnose ruptured membranes are reviewed. These options include subjective, objective, invasive and other diagnostic methods. It goes without saying that an optimal diagnostic technique should be noninvasive, objective and reproducible.

In Chapter 3 the results are discussed of an inquiry performed among all subjects that delivered in 3 medium-size hospitals in the southern part of the dutch province of Limbourg over a period of one year $(1985, \mathrm{n}=2903)$. The inquiry was aimed to evaluate the incidence of inconclusive outcome of the routine diagnostic procedure in nonlabouring patients suspected of having ruptured membranes. In 166 subjects (5.7\%) complying with these criteria, routine diagnostic work-up failed to confirm or reject the clinical diagnosis of ruptured membranes.

Clinical data of a representative sample of the population in the Netherlands that gave birth in a hospital in 1985, and in whom labor was preceded by a brief $(\leq 24$ h) period of ruptured membranes were compared with their counterparts in which the membranes had been ruptured for a period over $24 \mathrm{~h}$ prior to labor. The results of this comparison are discussed in chapter 4 . The data needed for this comparison were provided by the "S.I.G." (Stichting Informatie-centrum Gezondheidszorg), a dutch foundation which collects in a data base, clinically relevant data from $70 \%$ of the hospital deliveries in the Netherlands. This analysis served the purpose to determine whether the length of ruptured membranes influenced the incidence of various complications of PROM. The records were retrieved from 3799 and 3870 
subjects with membranes ruptured for less than and over $24 \mathrm{~h}$ prior to labor, respectively. PROM defined as rupture of the membranes before the onset of labor irrespective of gestational age, occurred in $19.1 \%$ of all hospital deliveries. If the membranes had been ruptured for more than $24 \mathrm{~h}$ prior to labor, the incidence of neonatal and postpartum maternal morbidity (infections) and with it, the length of hospital stay is significantly increased relative to the group of patients in which the membranes had been ruptured for a period of less than $24 \mathrm{~h}$ prior to labor.

The observation that morbidity increases as a function of the duration of ruptured membranes prior to labor raises the question whether this phenomenon has consequences for patients with suspect vaginal fluid loss in which uncertainty about the state of the membranes persists during subsequent clinical management. This led to the following study. Maternal/neonatal morbidity and neonatal mortality in subjects in which the origin of suspect vaginal fluid loss had remained unsolved according to the inquiry in 1985 (chapter 3) were supplemented with similar subjects evaluated in these 3 clinics in the subsequent 6 months $(n=273$ ). These subjects, classified as patients with failure to diagnose unequivocally either intact or ruptured membranes, were compared with the subjects retrieved in chapter 4 with certain diagnosis of less than $24 \mathrm{~h}$ ruptured membranes before labor $(n=3799)$ as well as with those in which the membranes were ruptured for over $24 \mathrm{~h}$ prior to labor $(n=3870)$. The results of this comparison are discussed in chapter 5 . It was found that the "failure-to-diagnose" group resembled the one with prolonged rupture of the membranes. Particularly maternal infection (endometritis) occurred more frequently.

It was noted in the analysis of the inquiry described in chapter 3 and in the preceding study that the clinical course in patients with persisting uncertainty about the state of the membranes, even at term, seemed to be more complicated than in patients matched for gestational age with confirmed ruptured or intact membranes. In order to evaluate whether the incidence of inconclusive diagnosis $(5.7 \%)$ can be reduced, the following study was performed. The diagnostic strength of the available methods to confirm rupture of the membranes are discussed in chapter 6 . In 203 patients with certainty about the state of the membranes and with a gestational age varying between 16 and 42 weeks, samples were obtained of amniotic fluid, serum, urine, vaginal discharge and cervical mucus. In these aliquots as well as in semen samples of 5 fertile men, 11 potentially relevant biochemical and/or physical indices were quantified resulting in 11 mean concentrations for each body fluid tested. Thus, a "biochemical profile" was obtained for each of these 6 reference fluids. The high viscosity of vaginal discharge, cervical mucus and fluid recovered from patients with minimal suspect vaginal fluid loss, made it necessary to interpolate an extraction procedure between sampling and biochemical analysis. Extraction reduced the minimum volume required for biochemical analysis to 0.1 $\mathrm{ml}$. As a direct consequence of the extraction, biochemical concentrations had to be expressed per gram of protein rather than per unit volume. Particularly blood 
contamination was found to interfere with the measurement when the prolactin concentration was not expressed per unit protein. The sensitivity and specificity of 10 of 11 indices were low in identifying amniotic fluid among the 6 reference fluids. Only the sensitivity and specificity of prolactin was high enough to differentiate between amniotic fluid and the other potential vaginal fluids.

In subjects $(n=100)$ with uncertainty about the ruptured or intact state of the membranes (also included in the analysis described in chapter 5), a sample of suspect vaginal fluid was analysed as delineated in the preceding paragraph. Sensitivity and specificity of the prolactin measurement to identify subjects with amniotic fluid leakage from those with fluid loss of nonamniotic origin amounted to $90 \%$. It was concluded that the prolactin-to-protein ratio has potential to be used as a diagnostic test to identify subjects with "silent" ruptured membranes among pregnant patients with suspect vaginal fluid loss.

By using a logistic regression technique the diagnostic strength of various combinations of the 11 indices was determined and compared with the diagnostic efficacy of the prolactin/protein ratio. The results are described in chapter 7. All combinations tested had a lower sensitivity at a given specificity, as compared to the prolactin/protein ratio alone with respect to identifying amniotic fluid among the 5 other fluids.

In chapter 8, the options nowadays available to diagnose rupture of the membranes are reviewed. Finally, possible future developments are discussed with pursued endpoint, a simple and reliable diagnostic test to detect amniotic fluid, available to each clinician dealing with pregnant patients complaining of increased vaginal fluid loss of unknown origin. 


\section{Literatuur}

T. Abe: The detection of the rupture of fetal membranes with the nitrazine indicator. Am J Obstet Gynecol 39:400,1940

L. Alger, J.Lovchik, J. Hebel, L. Blackmon, C. Crenshaw: The association of clamydia trachomatis, Neisseria gonorroeae, and group B streptococci with preterm rupture of the membranes and pregnancy outcome.

Am J Obstet Gynecol 159:397,1988

L. Allan, M. Ferguson, I. Donald, E. Sweet, A. Gibson: Amniotic fluid alpha-fetoprotein in the antenatal diagnosis of spina bifida.

Lancet ii:522,1973

N. Al-Zaid, M. Bou-Resli, G. Goldspink: Bursting pressure and collagen content of fetal membranes and their relation to premature rupture of the membranes.

Br J Obstet Gynaecol 87:227,1980

J. Amy, S. Karim: Prostaglandins and other oxytocic substances in amniotic fluid.

In: D. Fairweather, T. Eskes: Amniotic fluid. Research and clinical application. Excerpta Medica, Amsterdam, Oxford, New York, tweede druk, 1978, pagina 321.

J. Andersen: Prolactin in amniotic fluid and maternal serum during uncomplicated human pregnancy. Dan Med Bull 29:266,1982

R. Artal, R. Sokol, M. Neuman, A. Burnstein, J. Stojkov: The mechanical properties of prematurely and non-prematurely ruptured membranes. Methods and preliminary results.

Am J Obstet Gynecol 125:655,1976

R. Artal, R. Burgeson, F. Fernandez, C. Hobel: Fetal and maternal copper levels in patients at term with and without premature rupture of membranes.

Obstet Gynecol 53:608,1979

R. Artal, R. Burgeson, C. Hobel, D. Hollister: An in vitro model for the study of enzymatically mediated biomechanical changes in the chorioamniotic membranes.

Am J Obstet Gynecol 133:656,1979

N. Arts en G. Kloosterman: Groei en ontwikkeling van embryo, foetus en secundinae.

In: G. Kloosterman: De voortplanting van de mens. Leerboek voor obstetrie en gynaecologie. Uitgeversmaatschappij Centen Weesp, zevende druk, 1985, pagina 130.

S. Aschheim, B. Zondek: Hypophysen vorderlappenhormon und ovarialhormon im Harn von Schwangeren.

Link Wschr 6:1322,1927

R. Atlay, J. Sutherst: Premature rupture of the fetal membranes confirmed by intra-amniotic injection of dye (Evans blue T-1824).

Am J Obstet Gynecol 108:993,1970

H. Avarette, B. Hopman, J. Ferguson: Cytodiagnosis of ruptured fetal membranes. Fur:her experiences.

Am J Obstet Gynecol 87:226,1963. 
gebruikte literatuur

H. Bada, L. Alojipan, B. Andrews: Premature rupture of membranes and its effect on the newborn. Pediatr Clin North Am 24:491,1977

O. de Bakker-Teunissen: Human amniotic fluid prolactin and the feral membranes.

Dissertatie Vrije Universiteit Amsterdam 1986 "All in" B.V. Karwijk.

C. Bank, J. Offermans, A. Gijzen, M. v. Dieyen, P. Brombacher, F. Smits: Diamine Oxydase in amniotic fluid for diagnosis of ruptured membranes.

Aangeboden en geaccepteerd ter publicatie 1990

A. Baptisti: Chemical test for the determination of ruptured membranes.

Am J Obstet Gynecol 35:688,1938

D. Barford, L. Dickerman, W. Johnson: Alpha-fetoprotein: relationship between maternal serum and amniotic fluid levels.

Am J Obstet Gynecol 151:1038,1985

C. Bauer, L. Stern, E. Colle: Prolonged rupture of the membranes associated with a decreased incidence of respiratory distress syndrome.

Pediatrics, 53:7,1974

K. Beck, U. Budde, A. Neuhaus, K. Seifert: Die kristallografischen Grundlagen des Arborationsphaenomenes des Cervixschleimes.

Arch Gynaek 210:76,1971

R. Bejar, V. Curbelo, C. Davis, L. Gluck: Premature Labor. 2. Bacterial sources of phospholipase. Obstet Gynecol 57:479,1981

M. Bender Braverman, A. Bagni, D. Ziegler, T. Den, E. Gurpide: Isolation of prolactinproducing cells from first and second trimester decidua.

$J$ Clin Endocrinol Metab 58:521,1984

B. ten Berge: De hygiëne in de zwangerschap.

In: A. Holmer: Leerboek der verloskunde. Van Dishoeck, Van Holkema en Warendorf N.V., Bussum, derde druk, 1967, pagina 150.

C. Bergstrand, B. Czar: Demonstration of a new protein fraction in serum from the human fetus. Scand J Clin Lab Invest 8:174,1956

P. Berle: Der Gehalt an Chorialem Gonadotropin im Fruchiwasser während normaler und pathologischer Schwangerschaft.

Acta Endocrinol 61:369,1969

R. Berkowitz, R. Kantor, G. Beck, J. Warshaw: The relationship between premature rupture of the membranes and the respiratory distress syndrome. An update and plan of management.

Am J Obstet Gynecol 131:503,1978 
R. Berkowitz, E. Hoder, R. Freedman, D. Scott, M. Maltzer: Results of a management protocol for premature rupture of the fetal membranes.

Obstet Gynecol 60:271.1982

C. Best: The disappearance of histamine from autolysing lung tissue.

$J$ Physiol (Lond) 67:126,1929

M. Bigazzi, R. Ronga, I. Lancranjan, S. Ferraro, F. Branconi, P. Buzzoni, C. Martorana, C. Scarselli, E. del Pozzo: A pregnancy in an acromegalic woman during bromocriptine treatment: effects on Growth Hormone and prolactin in the maternal, fetal, and amniotic compartments.

J Clin Endocrinol Metab 48:9,1979

L. Blackmon, C. Crenshaw: Streptococci with preterm rupture of the membranes and pregnancy outcome.

Clin Obstet Gynecol 29:779,1986

S. Biswas: Prolactin in amniotic fluid: its correlation with maternal plasma prolactin.

Clin Chem Acta 73:363,1976

W. Blom: Het syndroom van Ehlers-Danlos.

Ned Tijdschr Geneeskd 127:1054,1983

R. Botta, M. Donatelli, A. Zampardi, T. Incandela, P. Valenza, V. Albano, G. Bompiani: Study on maternal, fetal and amniotic prolactin in gestational diabetic women, at term.

Acta Diabetol Lat 19:275,1982

A. Bourgeois: The identification of fetal squamas and the diagnosis of ruptured membranes by vaginal smear.

Am J Obstet Gynecol 44:80,1942

D. Brock, R. Sutcliffe: Alpha-fetoprotein in the antenatal diagnosis of anencephaly and spina bifida. Lancet ii:197,1972

I. Brosens, H. Gordon: The cytological diagnosis of ruptured membranes using Nile blue sulphate staining.

J Obstet Gynaec Brit Cmwth 72:342,1965

J. Bruner: Distribution of chorionic gonadotrophin in mother and fetus at various stages of pregnancy.

$J$ Clin Endocrinol 11:360,195I

R. Burchell: Premature spontaneous rupture of the membranes.

Am J Obstet Gynecol 88:251,1964

L. Calkins: Premature spontaneous rupture of the membranes.

Am J Obstet Gynecol 64:871,1952

D. Casal: Detection of amniotic fluid in the vagina using the ROMcheck immunoassay.

Technical Bulletin tb-17,1,1990 
gebruikte literatuur

L. Cederqvist, I. Zervoudakis, L. Ewool, S. Litwin: The relationship between prematurely ruptured membranes and fetal immunoglobulin production.

Am J Obstet Gynecol 134:784,1979

T. Chard, A. Klopper: Placental function tests.

Springer Verlag Berlin, Heidelberg, New York, tweede druk, 1982.

K. Christensen, P. Christensen, I. Ingemarsson, P. Mardh, E. Nordenfelt, T. Ripa, T. Solum, N. Svenningson: A study of complications in preterm deliveries after prolonged premature rupture of the membranes.

Obstet Gynecol 48:670,1976

D. Clark, G. Anderson: Perinatal mortality and amnionitis in a general hospital population. Obstet Gynecol 88:251,1964

Collaborative group on antenatal steroid therapy: Effect of antenatal dexamethasone administration on the prevention of respiratory distress syndrome.

Am J Obstet Gynecol 141:276,1981

F. Conell, T. Koepsell: Measures of gain in certainty from a diagnostic test.

Am J Epid 121:744,1985

D. Cotton, L. Hill, T. Strassner, L. Platt, W. Ledger: Use of amniocentesis in preterm gestation with ruptured membranes.

Obstet Gynecol 63:38,1984

R. Cowett, D. Hakanson, R. Kocon, W. Oh: Untoward neonatal effect of intraamniotic administration of methylene blue.

Obstet Gynecol 48:74S,1976

C. Creatsas, M. Pavlatos, D. Lolis, D. Aravantinos, D. Kaskarelis: Bacterial contamination of the cervix and premature rupture of membranes.

Am J Obstet Gynecol 139:522,1981

N. Daikoku, F. Kaltreider, V. Khouzami, M. Spence, J. Johnson: Premature rupture of membranes and spontaneous preterm labor: maternal endometritis risks.

Obstet Gynecol 59:13,1982

B. Dattatreyamurty, A. Sheth, T. Purandare, R. Companiwalla, U. Krishna: Gonadotrophins during second trimester of pregnancy: I. LH and hCG levels in maternal serum and amniotic fluid and their relationship to the sex of the foetus.

Acta Endocrinol 91:692,1979

M. Dawood: Hormones in amniotic fluid.

Am J Obstet Gynecol 128:576,1977

M. Dijxhoorn: Asphyxia at birth and neonatal neurological morbidity.

Dissertatie Rijksuniversiteit Groningen, Drukkerij van Denderen b.v. Groningen, 1986. 
gebruikte literaruur

P. Dufr: Management of premature rupture of membranes and unfavorable cervix in term pregnancy. Obstet Gynecol 63:697,1984

T. Eggers, L. Doyle, R. Pepperell: Premature rupture of the membranes. Med J Aust 1:209,1979

L. Ekvall, W. Wixted, I. Dyer: Spontaneous premature rupture of the fetal membranes. A review of 363 cases.

Am J Obstet Gynecol 81:848,1961

B. Elmfors, N. Tryding, G. Tufvesson: The diagnosis of ruptured fetal membranes by measurement of the diamine oxidase (DAO) activity in vaginal fluid.

J Obstet Gynaecol Brit Cwlth 81:361,1974

G. Evaldson, A. Lagrelius, J. Winiarski: Premature rupture of the membranes.

Acta Obstet Gynecol Scand 59:385,1980

G. Evaldson, B. Larsson, H. Jiborn: Is collagen content reduced when the fetal membranes rupture? A clinical study of term and prematurely ruptured membranes.

Gynecol Obstet Invest 24:92,1987

J. Evers: Voortijdig gebroken vliezen.

Ned Tijdschr Geneeskd 126:1682,1982

D. Fairweather: Techniques and safery of amniocentesis.

In: D. Fairweather, T. Eskes: Amniotic fluid. Research and clinical application. Excerpta Medica, Amsterdam, Oxford, New York, tweede druk, 1978, pagina 19.

V. Fang, M. Kim: Study on maternal, fetal, and amniotic human prolactin at term.

$J$ Clin Endocrinol Metab 41:1030,1975

J. Fayez, A. Hasan, H. Jonas, L. Miller: Management of premature rupture of the membranes. Obstet Gynecol $52,17,1978$

S. Feinstein, A. Vintzileos, J. Lodeiro, W. Campbell, P. Weinbaum, D. Nochimson: Amniocentesis with premature rupture of membranes.

Obstet Gynecol 68:147,1986

M. Ferron, R. Bilodeau: Amniotic fluid crystallization test for ruptured membranes.

Can Med Assoc J 89:1064,1963

J. Fleiss: Statistic methods for rates and proportions.

John Wiley and Sons, New York, Chichester, Brisbane, Toronto, tweede druk, 1981, pagina 218.

L. Frame, L. Wiley, A. Rogol: Indirect immunofluorescent localization of prolactin to the cytoplasm of decidua and trophoblastic cells in human placental membranes at term.

J Clin Endocrinol Metab 49:435,1979 
gebruikte literatuur

R. Freeman, M. Lev-Gur, R. Boyar, H. Schulman: Studies of maternal plasma prolactin and amniotic fluid prolactin. Effects of chlorpromazine and prostaglandin $F 2$ alpha.

Obstet Gynecol 47:282,1976

H. Friesen, P. Hwang, H. Guyda, G. Tolis, J. Tyson, R. Myers: A radioimmunoassay for human prolactin. Physiological, pathological and pharmacological factors which affect the secretion of prolactin. In: A. Boynes, K. Grifnths: Prolactin and carcinogenesis. Alpha Omega Alpha Publishing, College Buidings, University Palace Cardiff. Wales, U.K. 1972 pagina 64.

Y. Fukamatsu, K. Tomita, T. Fukuta: Further evidence of prolactin production from human decidua and its transport across fetal membranes.

Gynecol Obstet Invest 17:309,1984

W. Gahl, T. Kozina, D. Fuhrmann, A. Vale: Diamine oxidase in the diagnosis of ruptured fetal membranes.

Obstet Gynecol 60:297,1982

S. Gall, W. Spellacy: Cytologic diagnosis of ruptured membranes.

Obstet Gynecol 24:732,1964

T. Garite, R. Freeman, E. Linzey, P. Braly, W. Dorchester: Prospective randomized study of corticosteroids in the management of premature rupture of the membranes and the premature gestation.

Am J Obstet Gynecol 141:508,1981

H. v. Geuns, H. v. Kessel: Creatinine in amniotic fluid and fetal renal function.

In: D. Fairweather, T. Eskes: Amniotic fluid. Research and clinical application. Excerpta Medica, Amsterdam, Oxford, New York, tweede druk, 1978, bladzijde 81.

C. Gibbs, W. Locke: Maternal deaths in Texas, 1969 to 1973. A report of 501 consecutive maternal deaths from the Texas Medical Association's Commintee on Maternal Health.

Am J Obstet Gynecol 126:687,1976

R. Gibbs, J. Blanco: Premature rupture of the membranes.

Obstet Gynecol 60:671,1982

L. Gluck, M. Kulovich: Lecithin/sfingomyelin ratios in amniotic fluid in normal and abnormal pregnancy.

Am J Obstet Gynecol 115:539,1973

A. Golander, T. Hurley, J. Barrett, A. Hizi, S. Handwerger: Prolactin synthesis by human chorion-decidual tissue: a possible source of prolactin in the amniotic fluid.

Science 202:311,1978

V. Gold: Zur Diagnose des Blasensprunges.

Zentralbl Gynäkol 24:1491,1927

R. Goodlin, W. Clewell: Sudden fetal death following diagnostic amniocentesis.

Am J Obstet Gynecol 118:285,1974 
gebruikte literatuur

G. Gorodeski, M. Paz, V. Insler, J. Fishel: Diagnosis of rupture of the fetal membranes by glucose and fructose measurements.

Obstet Gynecol 53:611,1979

J. Gottdiener, C. Ellison, R. Lorenzo: Arteriovenous fistula after penetration at amniocentesis.

$N$ Engl J Med 293:1302,1975

G.Gunn, D.Mishell, D. Morton: Premature rupture of the fetal membranes. A review.

Am J Obstet Gynecol 106:469,1970

N. Hahnemann, A. Soerensen: Studies on alkaline phosphatase in amniotic fluid.

Acta Obstet Gynecol Scand 53:15,1974

S. Handweger, S. Wilson, M. Conn: Different subcellular storage sites for decidual- and pituitary-derived prolactin: possible explanation for differences in regulation.

Mol Cell Endocrinol 37:83,1984

R. Harrison: Amniotic fluid creatinine levels in the normotensive and pre-eclamptic patient.

J Obstet Gynaecol Br Cmwth 80:338,1973

T. Hasaart, G. Essed: Amniotic fluid embolism after transabdominal amniocentesis.

Eur J Obstet Gynecol Reprod Biol 16:25,1983

D. Healy, H. Muller, H. Burger: Immunofluorescence shows localisation of prolactin to human amnion.

Nature 265:642,1977

D. Healy, W. Kimpton, H. Muller, H. Burger: The synthesis of immunoreactive prolactin by decidua-chorion.

Br J Obstet Gynaecol 86:307,1979

M. Higginbottom, K. Jones, B. Hall, D. Smith: The amniotic band disruption complex: Timing of amniotic ruprure and variable spectra of consequent defects.

J Pediatr 95:544,1979

R. Hjertberg, P. Belfrage, P. Eneroth: Latex agglutination test for alpha-fetoprotein in the diagnosis of premature rupture of the amniotic membranes (PROM).

Acta Obstet Gynecol Scand 66:437,1987

P. van der Hoeven: De hygiëne in de zwangerschap.

In: P. van der Hoeven: Physiologie van de zwangerschap baring en kraambed. Willem Vorselmans, Zundert, tweede druk, 1924, pagina 130.

C. Hopman, J. Wargo, S. Werch: Cytology of vernix caseosa cells.

Obstet Gynecol 10:656,1957 
gebruikte literatuur

J. Huber, P. Bischof, P. Extermann, F. Beguin, W. Herrmann: Are vaginal fluid concentrations of prolactin, alpha-feto-protein and human placental lactogen useful for diagnosing ruptured membranes?

Br J Obstet Gynaecol 90:1183,1983

H. Huisjes: Amniotic fluid cytology.

Dissertatie Rijksuniversiteit Groningen, Van Gorkum \& Comp. N.V. Assen 1968.

P. Hwang, H. Guyda, H. Friesen: A radioimmunoassay for human prolactin.

Proc Natl Acad Sci U S A 68:1902,1971

S. Iacobelli, N. Garcea, C. Angeloni: Biochemistry of cervical mucus: a comparative analysis of the secretion from pre-ovulatory, postovulatory, and pregnancy periods.

Fertil Steril 22:727,1971

O. Iannetta: A new simple test for detection rupture of the fetal membranes.

Obstet Gynecol 63:575,1984

Y. Ito, K. Higashi: Studies on the prolactin-like substances in human placenta.

Endocrinol Jpn 8:279,1961

J. Johnson, N. Daikoku, J. Niebyl, T. Johnson, V. Khouzami, F. Witter: Premature rupture of the membranes and prolonged latency.

Obstet Gynecol 57:547,1981

M. Jones, L. Burd, W. Bowes, F. Battaglia, L. Lubchenco: Failure of association of premature rupture of membranes with respiratory distress syndrome.

$N$ Engl J Med 292:1253,1975

J. Josimovich, J. MacLaren: Presence in the human placenta and term serum of a highly lactogenic substance immunologically related to pituitary Growth Hormone.

Endocrinology 71:209,1962

J. Josimovich, G. Weiss, D. Hutchinson: Sources and deposition of pituitary prolactin in maternal circulation, amniotic fluid, fetus and placenta in the pregnant rhesus monkey.

Endocrinology 94:1364,1974

J. Josimovich: Hormones in amniotic fluid.

In: D. Fairweather, T. Eskes: Amniotic fluid. Research and clinical application. Excerpta Medica, Amsterdam, Oxford, New York, tweede druk, 1978, pagina 209.

K. Kappy, C. Cetrulo, R. Knuppel, C. Ingardia, A. Sbarra, J. Scerbo, G. Mitchell: Premature rupture of the membranes: a conservative approach.

Am J Obstet Gynecol 134:655,1979

F. Kardos, J. Tamasi: A new method to determine rupture of the membranes.

Magy Noorv Lap 18:286,1955 
K. Kasai, S. Shik, Y. Yoshida: Production and localization of human prolactin in placenta and decidua in early and at term normal pregnancy.

Biol Res Pregnancy 3:25,1982

M. Keirse, M. Mitchell, A. Turnbull: Changes in prostaglandin $F$ and 13,14-dihydro-15-ketoprostaglandin F concentrations in amniotic fluid at the onset of and during labour.

Br J Obstet Gynaecol 84:743,1977

J. Kellen, D. Kaspar, K. Leung: Alkaline Phosphatases from amniotic fluid.

Enzym Biol Clin 11:429,1970

E. Kesserue: A simple method for measuring crystallization of the cervical mucus and its application in human sperm migration.

Int J Fertil 17:201,1972

I. Kirsch, H. Cohen: Heinz body hemolitic anemia from the use of methylene blue in neonates.

$J$ Pediatr 96:276,1980

M. Kittrich: Zytodiagnostik des fruchtwasserabflusses mit Hilfe von Nilblau.

Geburtshilfe Frauenheilkd 23:156,1963

M. Kittrich, Z. Stembera, J. Hodr: Ein Vergleich der Milchsaure-konzentration im Fruchtwasser sowie im mütterlichen und im kindlichen Blut waehrend der Geburt.

Zentralbl Gyndkol. 17:566,1965

A. Kjessler: The time factor in rupture of the membranes and its influence on perinatal foetal mortality.

Acta Obstet Gynecol Scand 35:495,1956

K. Koh, F. Chan, A. Monfared, W. Ledger, R. Paul: The changing perinatal and maternal outcome in chorioamnionitis.

Obstet Gynecol 53:730,1979

P. Koninckx, H. Trappeniers, F. v. Assche: Prolactin concentration in vaginal fluid: a new method for diagnosing ruptured membranes.

Br J Obstet Gynaecol 88:607,1981

D. Kovacs: Crystallization test for the diagnosis of ruptured membranes. Am J Obstet Gynecol 83:1257,1962

M. Kroeks: Cervixslijm.

Dissertatie Rijksuniversiteit Utrecht 1976 De Boer-Cuperus B.V. Utrecht.

T. Kubota, T. Kumasaka, Y. Yaio, A. Suzuki, M. Saito: Study on immunoreactive prolactin of decidua in early pregnancy.

Acta Endocrinol 96:258,1981 
gebruikte literatuur

T. Kubota, M. Nagae, Y. Yaoi, T. Kumasaka, M. Saito: Prolactin-releasing system in maternal, fetal, and amniotic compartments during labor.

Obstet Gynecol 68:80,1986

J. Kusche, W. Lorenz: Diamine Oxidase.

In: H. Bergmeyer: Methods of enzymatic analysis. V.C.H. Verlag und gesellschaft GmbH. Weinheim 1986, 3e druk 1986, deel 5, pagina 237.

D. Kushner, I. Wang Chang, J. Vercruysse: Fluorescence microscopy for determination of ruptured fetal membranes by vaginal smear.

Obstet Gynecol 23:196,1964

R. Lamont, M. Rose, M. Elder: Effect of bacterial products on prostaglandin E production by amnion cells.

The Lancet ii:1331,1985

M. Lange Friedman, T. McElin: Diagnosis of ruptured fetal membranes. Clinical study and review of the literature.

Am J Obstet Gynecol 104:544,1969

W. Langreder: Der Blasensprungnachweis und seine Probleme.

Gynaecologia 145:257,1958

L. Lanier, R. Scarbrough, D. Fillingim, R. Baker: Incidence of maternal and fetal complications associated with rupture of the membranes before onset of labor.

Am J Obstet Gynecol 93:398,1965

J. Larsen: Premature amniorrhexis.

Obstet Gynecol Ann 8:203,1979

J. Lavory, C. Miller: Effect of prostaglandin and seminal fluid on human chorioamniotic membranes. JAMA 245:2425,1981

T. Lebherz, C. Boyce, J. Huston: Premature rupture of the membranes. A statistical study from 7 U.S. Navy hospitals.

Am J Obstet Gynecol 81:658,1961

W. Ledger: Premature rupture of membranes and maternal-fesal infection.

Clin Obstet Gynecol 22:329.1979

J. Lenihan: Relationship of antepartum pelvic examinations to premature rupture of the membranes. Obstet Gynecol 63:33,1984

K. Levick: Pregnancy loss and fathers with Ehlers-Danlos syndrome.

The Lancet ii:1151,1989

A. Lopez Bernal, D. Hansell, S. Alexander, A. Turnbull: Steroid conversion and prostaglandin production by chorionic and decidual cells in relation to term and preterm labour.

Br J Obstet Gynaecol 94:1052,1987a 
gebruikte literatuur

A. Lopez Bernal, D. Hansell, R. Soler, J. Keeling, A. Turnbull: Prostaglandines, chorioamnionitis, and preterm labour.

Br J Obstet Gynaecol 94:1156,1987b

A. Luciano, M. Varner: Decidual, amniotic fluid, maternal and fetal prolactin in normal and abnormal pregnancies.

Obstet Gynecol 63:384,1984

E. Markoff, S. Howell, S. Handwerger: Inhibition of decidual prolactin release by a decidual peptide.

$J$ Clin Endocrinol Metab 57:1282.1983

J. Marks, C. Church, G. Benrubi: Effects of barometric pressure and lunar phases on premature rupture of the membranes.

J Reprod Med 28:335,1983

R. Maudsley, G. Brix, N. Hinton, E. Robertson, A. Bryans, M. Haust: Placental inflammation and infection. A prospective bacteriologic and histologic studty.

Am J Obstet Gynecol 95:648,1966

J. McCoshen, O. Tagger, A. Wodzicki, J. Tyson: Choriodecidual adhesion promotes decidual prolactin transport by human fetal membrane.

Am J Physiol 243:R552,1982a

J. McCoshen, K. Tomita, C. Fernandez, J. Tyson: Specific cells of human amnion selectively localize prolactin.

$J$ Clin Endocrinol Metab 55:166,1982b

J. McCoshen, J. Barc: Prolactin bioactivity following decidual synthesis and transport by amniochorion.

Am J Obstet Gynecol 217:153,1985

P. Mead: Management of the patient with premature rupture of the membranes.

Clin Perinatol 7:2,1980

J. Merkus: Lecithine, vruchtwater en RDS.

Dissertatie Vrije Universiteit Amsterdam, Schriks drukkerij b.v. Asten N.-Br 1974.

R. Meudt, E Meudt: Rupture of the fetal membranes. An experimental, clinical, and histologic study. Am J Obstet Gynecol 99:562,1967

M. Meyer, J. Tonascia: Maternal smoking, pregnancy complication and perinatal mortality. Am J Obstet Gynecol 128:494,1977

J. Miller, M. Pupkin, C. Crenshaw: Premature labor and premature rupture of the membranes. Am J Obstet Gynecol 132:1,1978 
gebruikte literatuur

M. Miller, J. Graham, M. Higginbottom, D. Smith: Compression-related defects from early amnion rupture: Evidence for mechanical teratogenesis.

J Pediatr 98:292,1981

S. Millingos, I. Messinis, D. Diakomanolis, D. Aravantinos, D. Kaskarelis: Influence of meteorological factors on premature rupture of fetal membranes.

Lancet ii:435,1978

A. Mills, D. Garrioch: Use of the nitrazine yellow swab test in the diagnosis of ruptured membranes. Br J Obstet Gynaecol 84:138,1977

J. Mills, S. Harlap: Should coitus late in pregnancy be discouraged?

Lancet $i: 136.1981$

M. Mitchell, A. Flint, J. Bibby, J. Brunt, J. Arnold, A. Anderson, A. Turnbull: Rapid increases in plasma prostaglandin concentrations after vaginal examination and amniotomy.

Br Med J 2:1183,1977

K. Moghissi, F. Syner, T. Evans: A composite picture of the menstrual cycle.

Am J Obstet Gynecol 114:405,1972

R. Naeye: Causus of perinatal mortality in the US collaborative perinatal project.

JAMA 238:228,1977

R. Naeye: Coitus and associated amniotic fluid infections.

N Eng J Med 301:1198,1979

R. Naeye, E. Peters: Causus and consequences of premature ruprure of fetal membranes.

The Lancet $i: 192,1980$

R. Naeye: Safety of coitus in pregnancy.

The Lancet $i: 686,1981$

R. Naeye: Factors that predispose to premature rupture of the fetal membranes.

Obstet Gynecol 60:93,1982

R. Naeye, S. Ross: Coitus and chorioamnionitis: a prospective study.

Early Hum Dev 6:91,1982

L. Neuhaus: Einfaches und schnelles Verfahren zum Fruchtwassernachweis nach Blasensprung.

Geburtshilfe Frauenheilkd 9:856,1956

D. Nochimson, R. Petrie, B. Shah, N. Pampati, D. Brunelle: Comparison of conservative and dynamic management of premature rupture of membranes/premature labor syndrome. New approaches to the delivery of infants which may minimize the need for intensive care.

Clin Perinatol 7:17,1980

C. von Numers: A new method of diagnosis of rupture of the membranes.

Acta Obstet Gynecol Scand 16:249,1936 
M. Obladen, T. Merritt, L. Gluck: Acceleration of pulmonary surfactant maturation in stressed pregnancies: A study of neonatal lung effluent.

Am J Obstet Gynecol 135:1079,1979

T. Okuyama, Y. Kobayashi: Determination of diamine oxidase activiny by liquid scintillation counting.

Arch Biochem Biophys 95:242,1961

A. Paavola: Methods based on the study of crystals and fat staining. Use in diagnosing rupture of the membranes.

Ann chir et gynaecol Fenniae 47:22,1958

A. Papageorgiou, E. Colle, E. Farri, M. Gelfand: Incidence of respiratory distress syndrome following antenatal betameshasone: Role of sex, type of delivery, and prolonged rupture of membranes. Pediatrics 67:614,1981

G. Papanicoulaou: A general survey of the vaginal smear and its use in research and diagnosis. Am J Obstet Gynecol 51:316,1946

E. Parry-Jones, S. Priya: A study of elasticity and tension of fetal membranes and of the relation of the area of the gestational sac to the area of the uterine cavity.

Br J Obstet Gynaecol 83:205,1976

R. Perkins: The neonatal significance of selected perinatal events among infants of low birth weight. II. The influence of ruptured membranes.

Am J Obstet Gynecol 142:7,1982

E. Philipp, J. Williams: Zur Diagnose des vorzeitigen Blasensprunges.

Zentralbl Gynäkol 53:1618,1929

I. Phocas, A. Sarandakou, A. Kontoravdis, A. Chryssicopoulos, P. Zourlas: Vaginal fluid prolactin: a reliable marker for the diagnosis of prematurely ruptured membranes. Comparison with vaginal fluid alpha-feto-protein and placental lactogen.

Eur J Obstet Gynecol Reprod Biol 31:133,1989

R. Pitkin, S. Zwirek: Amniotic fluid creatinine.

Am J Obstet Gynecol 98:1135,1967

G. Polansky, M. Varner, T. O'Gorman: Premature rupture of the membranes and barometric pressure changes.

J Reprod Med 30:189,1985

W. Polishuk, S. Kohane, A. Peranio: The physical properties of fetal membranes.

Obstet Gynecol 20:204,1962

W. Polishuk, S. Kohane, A. Hadar: Fetal weight and membrane tensile strength.

Am J Obstet Gynecol 88:247,1964 
gebruikte literatuur

J. Quirk, R. Raker, R. Petrie, A. Williams: The role of glucocorticoids, unstressful labor, and atraumatic delivery in the prevention of respiratory distress syndrome.

Am J Obstet Gynecol 134:768,1979

D. Rabe, W. Leucht, H. Hendrik, H.Boos, W. Schmidt: Sonographische Beurteilung der Fruchrwassermenge. Il. Oligohydramnion-Bedeutung für den Schwangerschafts- und Geburtsverlauf. Geburtshilfe Frauenheilkd 46:422,1986

E. Reece, F. Chervenak, F. Moya, J. Hobbins: Amniotic fluid arborization: effect of blood. meconium, and $p H$ alterations.

Obstet Gynecol 64:248,1984

C. Richardson, J. Pomerance, M. Cunningham, L. Gluck: Acceleration of fetal lung maturation following prolonged rupture of the membranes.

Am J Obstet Gynecol 118:1115,1974

D. Riddick, A. Luciano, W. Kusmik, I. Maslar: De novo synthesis of prolactin by human decidua. Life Sci 23:1913,1978

D. Riddick, A. Luciano, W. Kusmik, I. Maslar: Evidence for a nonpituitary source of amniotic fluid prolactin.

Fertil Steril 31:35,1979

D. Riddick, I. Maslar: The transport of prolactin by human fetal membranes.

$J$ Clin Endocrinol Metab 52:220,1981

D. Riddick, D. Daly: Decidual prolactin production in human gestation.

Semin Perinatol 6:229,1982

L. Rigg, S. Yen: Multiphasic prolactin secretion during parturation in human subjects. Am J Obstet Gynecol 128:215,1977

C. Roberts, B. Hibbard, D. Evans, K. Evans, K. Laurance, M. Hoole, E. Roberts, W.Ennis: Precision in estimating gestational age and its influence on sensitivity of AFP screening.

Br Med J 1:981,1979

B. Rochelson, D. Richardson, J. Macri: Rapid Assay-Possible application in the diagnosis of premature rupture of the membranes.

Obstet Gynecol 62:414,1983

B. Rochelson, G. Rodke, R. White, L. Bracero, D. Baker: A rapid colorimetric AFP monoclonal antibody test for the diagnosis of preterm rupture of the membranes.

Obstet Gynecol 69:163,1987

M. Roland: Can the ferntest be graded?

Obstet Gynecol 37:792,1971 
gebruikte literatuur

R. Romero, M. Emamian, R. Quintero, M. Wan, J. Hobbins, M. Mitchell: Amniotic fluid prostaglandin levels and intra-amniotic infections.

Lancet i:1380,1986

M. Ron, U. Beller, J. Ori, M. Ben-David, Z. Palti: Prolactin concentration in the fetal membranes in pregnancies with premature rupture of the membranes and control pregnancies.

Am J Obstet Gynecol 143:482,1982

S. Roopnarinesingh: Amniotic fluid creatinine in normal and abnormal pregnancies.

J Obstet Gynaecol Br Cmwth 77:785,1970

S. Roopnarinesingh: Amniotic fluid creatinine.

J Obstet Gynaecol Br Cmwth 80:611,1973

S. Rosenberg, I. Maslar, D. Riddick: Decidual production of prolactin in late gestation: further evidence for decidual source of amniotic fluid prolactin.

Am J Obstet Gynecol 138:681,1980

C. Ruck: Der Kristalltest in der Fruchtblasensprungdiagnostik.

Zentrbl Gynäkol 152:215,1959

N. Rudd, C. Nimrod, K. Holbrook, P. Byers: Pregnancy complications in type IV Ehlers-Danlos syndrome.

Lancet i:50.1983

E. Ruoslahti, M. Seppälä: Studies of carcino-fetal proteins. III Development of a radioimmunoassay for AFP. Demonstration of AFP in serum of healthy human adults.

Int J Cancer 8:374,1971

E. Rutanen: Diagnosis of premature rupture of fetal membranes by the measurement of insulin-like growth factor binding protein-l in cervical secretion.

Am J Obstet Gynecol Suppl 164:258,1991

M. Sacks, T. Baker: Spontaneous premature rupture of the membranes. A prospective srudy. Am J Obstet Gynecol 97:888,1967

A. Sbarra, G. Thomas, C. Cetrulo, C. Shakr, A. Chaudhury, P. Benoy: Effect of bacterial growth on the bursting pressure of fetal membranes in vitro.

Obstet Gynecol 70:107,1987

J. Schenker, M. Ben-David, W. Polishuk: Prolactin in normal pregnancy: relationship of maternal. fetal, and amniotic fluid levels.

Am J Obstet Gynecol 123:834,1975

J. Schenker, M. Ben-David, D. Albin: Evidence of lack of passage of prolactin through human placental membranes.

Gynecol Obstet Invest 10:311,1979 
gebruikte literatuur

A. Schindler: Hormones in human amniotic fluid.

Monographs on endocrinology.

Springer Verlag Berlin, Heidelberg, New York 1982.

H. Schouten: Nominal scale agreement among observers.

Psychometrika 51:453.1986

J. Schumacher, C. Koehl, J. Abecassis, G. Boog, R. Walch, R. Gandar: Valeur du test d la diamino-oxidase dans le diagnostic de la rupture prematuré des membranes.

Rev Fr Gynecol Obstet 71:235,1976

M. Schutte: Over de behandeling van dreigende vroeggeboorte.

Dissertatie Universiteit van Amsterdam 1981 Rodopi Amsterdam.

E. Sell, T. Harris: Association of premature rupture of membranes with idiopathic respiratory distress syndrome.

Obstet Gynecol 49:167,1977

K. Seki, K. Kato: Increased boy-to-girl ratio in women with preterm labor beginning with contractions.

Am J Obstet Gynecol 157:215,1987

M. Seppälä: Alpha-fetoprotein in the amniotic fluid in relation to neural tube defects and other congenital/genetic disorders of the fetus.

In: D. Fairweather, T. Eskes: Amniotic Fluid. Research and clinical application. Excerpta Medica, Amsterdam, Oxford, New York, tweede druk, 1978, pagina 297.

M. Seppälä, E. Ruoslahti: Alpha fetoprotein in amniotic fluid: An index of gestational age.

Am J Obstet Gynecol 114:595,1972

E. Sklovsky, A. MacLennan: Reliable detection of ruptured membranes.

Br Med J 2:1014,1976

R. Smith, D. Callagan: Amniotic fluid crystallization test for ruptured membranes. Obstet Gynecol 5:655,1962

R. Smith: A technic for the detection of rupture of the membranes. A review and preliminary report. Obstet Gynecol 48:172,1976

J. Soria, E. Canales, G. Forsbach, S. Karchmer, V. Guzman, A. Zarate: Relationship of maternal, fetal, and amniotic fluid prolactin levels.

Ann Endocrinol 38:55,1977

C. Stedman, S. Crawford, E. Staten, W. Cherny: Management of premature rupture of membranes: assessing amniotic fluid in the vagina for phosphatidylglycerol.

Am J Obstet Gynecol 140:34,1981 
gebruikte literatuur

H. Taguchi, K. Miyamoto, Y. Takahashi, Y. Ibuki, M. Igarashi: The ionic heterogeneity of human prolactin (PRL) from amniotic fluid.

Nippon Sanka Fujinka Gakkai Zasshi 37:973,1985

N. Temesvary: Zur Diagnose des Blasensprunges.

Zentralbl Gynäkol 20:1180,1933

J. Thomason, S. Gelbart, L. Monagle, J. James, F. Broekhuizen: Is $p H$ test paper as accurate as the electronic measurement of the pH of vaginal secretions?

Am J Obstet Gynecol 162:1213,1990

J. Thornton, J. Hill, H. Bird: Complications of pregnancy and benign familial joint hyperlaxity. Ann Rheum Dis 47:228,1988

V. Tricomi, E. Hall, A. Bittar, D. Chambers: Arborization test for the detection of ruptured fetal membranes. Clinical evaluation.

Obstet Gynecol 27:275,1966

J. Tyson, P. Hwang, H Guyda, H. Friesen: Studies of prolactin secretion in human pregnancy. Am J Obstet Gynecol 113:14,1972

M. Varner, R. Galask: Conservative management of premature rupture of the membranes. Am J Obstet Gynecol 140:39,1981

P. Vige, V. Margerie, S. Dendrinos, R. Henrion, L. Cedard, Y. Janssens: Interêt du test à la diamine-oxydase (DAO) dans le diagnostic de la rupture spontané des membranes ovulaires.

J Gynecol Obstet Biol Reprod (Paris) 13:797,1984

W. Voets: Studie over de herkomst van troebeling en vlokken en het alkalische fosfatase in het vruchtwater.

Dissertatie Rijksuniversiteit Utrecht 1975 Concentra-Grafic Hasselt.

B. Volet, J. Morier-Genoud: Le test de cristallisation dans le liquide amniotique.

Gynaecologia 149:151,1960

N. Wagner, J. Butler, J. Sanders: Prematurity and orgasmic coitus during pregnancy: data on a small sample.

Fertil Steril 27:911,1976

G. Webb: Maternal death associated with rupture of the membranes. An analysis of 54 cases. Am J Obstet Gynecol 98:594,1967

J. Weed, A. Carrera: Glucose content of cervical mucus.

Fertil Steril $21: 866,1970$.

R. Weiss, J. Macri, K. Elligers, G. Princler, R. McIntire, T. Waldman: Amniotic fluid AFP as a marker in prenatal diagnosis of neural tube defects.

Obstet Gynecol 47:148,1976a 
gebruikte literatuur

R. Weiss, J. Macri, K. Elligers: Origin of amniotic fluid AFP in normal and defective pregnancies. Obstet Gynecol 47:697,1976b

R. Weiss, A. Frantz, J. Macri, J. Robins, J. Merker: Prolactin and human placental lactogen in maternal serum and amniotic fluid in midtrimester induced abortion.

Am J Obstet Gynecol 129:9,1977

L. Wide, B. Hobson: Immunological and biological activity of human chorionic gonadotrophin in urine and serum of pregnant women with a hydatidiform mole.

Acta Endocrinol 54:105,1967

G. Wideman, G. Baird, D. Baldin: Ascorbic acid deficiency and premature rupture of fetal membranes.

Am J Obstet Gynecol 88:592,1964

A. Widjaja: Klinische aspecten van voortijdig gebroken vliezen in de verloskunde.

Tijdschr voor Geneesk 40:519,1984

J. Wilson, D. Levy, P. Wilds: Premature rupture of membranes prior to term: Consequences of nonintervention.

Obstet Gynecol 60:601,1982

M. Wishart, D. Jenkins, M. Knott: Measurement of diamine oxidase activity in vaginal fluid - An aid to diagnosis of ruprured fetal membranes.

Aust N Z J Obstet Gynaecol 19:23.1979

D. Worthington, A. Maloney, T. Smith: Fetal lung maturity. 1. Mode of onset of premature labor. Influence of premature rupture of the membranes.

Obstet Gynecol 49:275,1977

J. Yoon, R. Harper: Observations on the relationship between duration of rupture of the membranes and the development of idiopathic respiratory distress syndrome.

Pediatrics 52:161,1973

P. Young, M. Matson, O. Jones: Fetal exsanguination and other vascular injuries from midtrimester genetic amniocentesis.

Am J Obstet Gynecol 129:21,1977

B. Zondek, S. Rozin: Cervical mucus arborization. Its use in determination of corpus luteum function. Obstet Gynecol 3:463,1954

B. Zondek: Arborization of cervical and nasal mucus and saliva.

Obstet Gynecol 13:477,1959 


\section{Bijlage 1}

\section{Overzicht Groepen}

$\begin{array}{lll}\begin{array}{l}\text { Pilot study } \\ \text { Groep K }\end{array} & \begin{array}{l}\text { onderzoeksgroep met staande vliezen } \\ \mathrm{n}=3799\end{array} & \begin{array}{l}\text { patiënten met kortdurend gebroken vliezen } \\ \text { geselecteerd uit S.I.G.-bestand }\end{array} \\ \text { Groep L } & \mathrm{n}=3870 & \begin{array}{l}\text { patiënten met langdurig gebroken vliezen } \\ \text { geselecteerd uit S.I.G.-bestand }\end{array}\end{array}$

$\begin{array}{lll}\text { Enquête-groep } & n=166 & \begin{array}{l}\text { onderzoeksgroep waarbij werd getwijfeld aan het } \\ \text { gebroken zijn van de vliezen }\end{array} \\ \begin{array}{l}\text { Groep met dubieus } \\ \text { gebroken vliezen }\end{array} & n=116 & \begin{array}{l}\text { onderzoeksgroep waarbij werd getwijfeld aan het } \\ \text { gebroken zijn van de vliezen en waarbij afgelo- } \\ \text { pen vocht werd onderzocht }\end{array}\end{array}$

Groep D $\quad \mathrm{n}=282$ combinatie van de enquêtegroep en de groep met dubieus gebroken vliezen

Groep met zekere

$n=203$

onderzoeksgroep waarbij met zekerheid bekend was of de vliezen stonden of waren gebroken 


\section{Bijlage 2}

Enquêteformulier betreffende het onderzoek

De diagnostiek van gebroken vliezen.

Ponsplaatje van patiënte

S.v.p. de volgende gegevens invullen:

- G .. P .. A ..

- Amenorroeduur:

...... weken..... dagen

- Termijn zeker: Ja / Nee

- Klachten patiënte:

- Klachten sinds: $\quad$ Datum: ...-.-19..

Tijd: .. uur .. minuten

- Onderzoek:

In speculo:

Vocht verkregen: Ja / Nee

Echoscopie: $\quad \mathrm{Ja} / \mathrm{Nee}$

- Vocht onderzocht: Varentest: Ja / Nee

$\mathrm{pH}: \quad$ Ja / Nee

Overige:

- Opname: Ja / Nee

- Onderzoeker: 


\section{Bijlage 3}

Ontwerp van het computervel dat werd gebruikt ter verwerking van de enquête van het onderzoeksproject: de diagnostiek van gebroken vliezen.

- Identificatie: Onderzoeksnummer

Ziekenhuis

Gynaecoloog/assistent

Herkomst

Verzekeringsvorm

- Bijzonderheden: Algemeen

Obstetrisch

Oorspronkelijk bedoelde plaats van de bevalling

Datum vorige bevalling of partus immaturus

- Aantal graviditeiten, waarvan abortus

A terme datum

Zeker/niet zeker

Datum eerste onderzoek

Was er sprake van een intra-uteriene vruchtdood?

- Datum waarop klacht begon

Datum onderzoek

Klacht bestaat uit

Opname

Onderzoek dat werd uitgevoerd

Medicatie ten tijde van klacht

Hoogste diastolische druk

Vliezen gebroken

Datum waarop de vliezen braken

Daarna medicatie tot bevalling

Datum van de baring

Tijdstip

Kind aangepakt door

Onder supervisie van 
bijlage 3

- Ligging

Begin van de baring

Indicatie inleiding

Begin van het persen

Hulp bij de baring

Indicatie voor de hulp

Perineum

Nageboortetijdperk

- Geslacht van het kind

Geboortegewicht

Apgarscore na 1 minuut

Apgarscore na 5 minuten

Conditie van het kind

Congenitale afwijkingen

$\mathrm{pH}$ arterieel

pH veneus

Reanimatie

Beleid pediater

Poliklinische contrôle na 3 maanden

Afwijkingen

Verdere contrôle

- Kraambed

Temperatuurverloop

Medicatie

Lochia

Borstvoeding

Post partum contrôle na 4 tot 6 weken

- Datum ontslag van de moeder

- Eigen coderingen 


\section{Bijlage 4}

Uitleg betreffende computervel voor het uitwerken van de enquête

Onderzoeksnummer: Uitgedeeld naar volgorde van binnenkomst

De Wever-Ziekenhuis 1

academisch ziekenhuis Maastricht 2

Sint Elisabeth Kliniek 3

Gynaecologen: De Wever-Ziekenhuis 1 Dr Schellekens

2 Dr Ubachs

3 Dr Stoot

4 Drs Zandvoort

5 Drs Degen

Academisch Ziekenhuis

1 Prof. de Haan

Maastricht

2 Drs de Koning Gans

3 Dr Smits

4 Dr Hoogland

5 Dr Hamilton

6 Dr Evers

7 Dr Essed

8 Dr Hasaart

St Elisabeth Kliniek

1 Dr F Roumen

2 Dr P. Bouckaert

3 Drs Turkow

Assistenten

De Wever-Ziekenhuis

1 Drs Zweers

2 Drs Offermans

3 Drs Salemans

4 Drs Snijders

5 Drs ten Kate

6 Drs Dunselman

7 Drs v. Soest 
bijlage 4

academisch zh $\mathrm{M}$ 'tricht
1 Drs Vonsee
2 Drs de Leeuw
3 Dr Land
4 Drs Dunselman
5 Drs Kornelis
6 Drs Hamers
7 Drs Valkenburg
8 Drs v. Vught
9 Drs Creusen
10 Drs v. Zijl

St Elisabeth Kliniek

1 Drs Baggen

2 Drs Smets

3 Drs Konsten

4 Drs v.d. Linden

5 Drs v. Huisseling

6 verloskundige

7 leerling

Herkomst

$\begin{array}{ll}\text { met klacht ingestuurd } & 1 \\ \text { eigen bestand } & 2 \\ \text { geen eerdere contrôles } & 3 \\ & \\ \text { Verzekeringsvorm particulier } & 1 \\ \text { fonds } & 2 \\ \text { geen } & 3\end{array}$

Bijzonderheden

algemeen

geen

wel: codeer beneden

L.V.R. formulier 01-0252

waarbij

01 niet-Nederlandse herkomst

02 aandoening tractus respiratorius

03 vitium cordis, al dan niet geopereerd

04 varices, al dan niet geopereerd

05 trombo-embolische processen

06 pre-existent vaatlijden

07 overige aandoeningen tractus circulatorius

08 hepatische afwijkingen

09 overige afwijkingen tractus digestivus

10 recidiverende urineweginfecties

11 abortus provocatus 
12 afwijkingen tractus urinarius

13 orthopedische afwijkingen en/of operaties

14 neurologische of neurochirurgische afwijkingen of operaties

15 psychiatrische aandoeningen

16 diabetes mellitus

17 overige endocriene afwijkingen

18 dermatologische afwijkingen

19 systeemziekten

20 maligne niet gynaecologische afwijkingen

21 congenitale uterusanomalie al dan niet geopereerd

22 uterus myomatosus

23 adnex afwijking, behandeling en/of endometriose behandeling

24 exconisatie en/of portio-amputatie

25 ongewenste kinderloosheid meer dan een jaar bestaande

obstetrisch

algemeen geen

wel: codeer beneden

1

L.V.R. formulier $26-40$

2

waarbij

26 partus immaturus (16-28 weken) in anamnese

27 partus prematurus (28-37 weken) in anamnese

28 intra-uteriene vruchtdood in de anamnese

29 dysmaturiteit $(<2,3 \%)$ in anamnese

30 bekkenvernauwing in anamnese

31 mola en of choriocarcinoom in anamnese

32 toxicose met opname in de anamnese

33 solutio placentae in de anamnese

34 placenta praevia met consequenties in anamnese

35 vaginale kunstverlossing in de anamnese

36 sectio caesarea in anamnese

37 totaalruptuur in de anamnese

38 fluxus post partum met transfusie in de anamnese

39 manuele placenta verwijdering in de anamnese

40 diabetes gravidarum met insulinebehandeling in anamnese

Oorspronkelijk bedoelde plaats van de bevalling

$\begin{array}{ll}\text { thuis } & 1 \\ \text { kraaminrichting } & 2 \\ \text { ziekenhuis met kraambed } & 1 \\ \text { ziekenhuis zonder kraambed } & 4\end{array}$

Datum vorige bevalling dag/maand/jaar 
bijlage 4

Aantal:

graviditeiten

$1-9$

abortus

$0-9$

à terme datum zeker

à terme datum niet zeker

Datum eerste onderzoek: dag/maand/jaar

Intra-uteriene vruchtdood: neen

ja

Datum klacht begon: dag/maand/jaar

Datum onderzoek: $\quad \mathrm{dag} / \mathrm{maand} / \mathrm{jaar}$

Klacht bestaat:

vochtverlies onwillekeurig 1

bloedverlies

pijn

3

echo weinig vruchtwater

4

combinatie

5

6

7

8

Opname:

neen

1

ja

Onderzoek:

$\begin{array}{lr}\text { geen } & 1 \\ \text { speculumonderzoek } & 2 \\ \text { vaginaal toucher } & 3 \\ \text { varentest } & 4 \\ \text { echoscopie } & 5 \\ \text { pH } & 6 \\ \text { opname en observatie } & 7 \\ \text { Nile-blue-sulfaattest } & 8 \\ \text { Prolactine } & 9 \\ \text { Andere dan bovenstaande } & 10\end{array}$


Medicatie:

$\begin{array}{ll}\text { geen } & 1 \\ \text { antibiotica systemisch } & 2 \\ \text { vaginale antimycotica } & 3 \\ \text { beta-mimetica } & 4 \\ & 5 \\ & 6 \\ & 7 \\ & 8\end{array}$

Vliezen gebroken:

zeker

zeker niet

onduidelijke diagnose

Datum waarop de vliezen zeker braken: dag/maand/jaar

Daarna medicatie:

$\begin{array}{ll}\text { geen } & 1 \\ \text { antibiotica systemisch } & 2 \\ \text { antimycotica lokaal } & 3 \\ \text { beta-mimetica } & 4 \\ \text { Syntocinon } & 5 \\ \text { Prostaglandines oraal } & 6 \\ \text { Prostaglandines lokaal } & 7 \\ \text { Prostaglandines intraveneus } & 8 \\ & 9\end{array}$

Datum van de baring: dag/maand/jaar

Tijdstip van de baring: uren/minuten

Kind aangepakt door: verloskundige 1 huisarts 2

co-assistent 3

assistent 4

gynaecoloog 5

overige 6

Eventuele supervisie: verloskundige 1

huisarts 2

co-assistent 3

assistent 4

gynaecoloog 5

overige 6 
bijlage 4

Ligging: achterhoofd $\quad 1$

kruin 2

aangezicht 3

voorhoofd 4

dwars 5

volkomen stuit 6

onvolkomen stuit $\quad 7$

stuit anderszins $\quad 8$

anders 9

Begin van de baring: $\quad$ spontane weeën $\quad 1$

spontane vliesscheur 2

inleiding amniotomie 3

inleiding chemisch 4

primaire sectio 5

Indicatie inleiding: $\quad$ electief 1

conditie kind 2

conditie moeder 3

conditie moeder en kind 4

Begin van het persen: uren/minuten

Hulp: $\quad$ geen 1

fundusexpressie 2

vacuümextractie 3

forceps 4

versie en extractie 5

problemen schouders 6

problemen met nakomend hoofd 7

primaire stuitextractie $\quad 8$

secundaire sectio 9

Indicatie hulp:

foetale nood 1

niet vorderen van baring 2

conditie moeder 3

anders 4 


$\begin{array}{llr}\text { Perineum: } & \text { gaaf } & 1 \\ & \text { ruptuur } & 2 \\ & \text { totaalruptuur } & 3 \\ & \text { laterale episiotomie } & 4 \\ & \text { mediane episiotomie } & 5 \\ \text { nageboorte: } & \text { geen complicaties } & 1 \\ & \text { hpp } & 2 \\ & \text { manuele placenta verwijdering } & 3 \\ & \text { overige } & 4 \\ \text { Geslacht kind: } & \text { meisje } & 1 \\ & \text { jongen } & 2 \\ & \text { onbekend } & 3\end{array}$

Geboortegewicht in grammen

Apgarscore: van 0 tot 10

Conditie kind:

levend mee naar huis

met moeder in ziekenhuis

2

naar pediater

3

overleden voor 28 weken

in utero

4

overleden in utero

na 28 weken

5

durante partu overleden

6

binnen 24 uur overleden

7

$2^{\mathrm{e}} \mathrm{t} / \mathrm{m} 7^{\mathrm{e}}$ dag overleden

Congenitaal:

zie L.V.R. lijst 01 tot 89

waarbij:

01 anencephalie

02 microcephalie

03 spina bifida occulta

04 spina bifida aperta

05 hydrocephalie

06 meningomyelocèle

07 encephalocèle

08

09 andere congenitale afwijkingen centraal zenuwstelsel

10 micro-ophtalmie

11 andere congenitale afwijkingen ogen 
bijlage 4

12 congenitale afwijkingen van de oren

13

14

15

16

17

18

19

20 vitium cordis

21 ontbreken van een navelarterie

22

23

24

25

26

27

28

29 andere congenitale vaatafwijkingen

30 choanaal atresie

31

32

33

34

35

36

38

39 overige afwijkingen tractus respiratorius

40 gehemeltespleet

41 lipspleet

42 oesophago-tracheale fistel

43 oesophagusatresie

44 overige darmatresie inclusief van de anus

45 hernia diafragmatica

46

47

48

49 andere congenitale afwijkingen tractus digestivus

50 hypospadie en epispadie

51

52

53

54

55 
59 andere congenitale afwijkingen tractus urogenitalis

60 naevus pigmentosus

61 haemangioma cavernosus

62

63

64

65

66

67

68

69 andere congenitale huidafwijkingen

70 polydactylie

71 syndactylie

72 focomelie en amelie

73 congenitale heupluxatie

74 pes equinovarus

75 andere congenitale afwijkingen van de extremiteiten 76 congenitale afwijkingen van bot en skelet

77

78

79 andere congenitale afwijkingen van het bewegingsstelsel 80 struma congenita

81 Down syndroom

82 andere chromosoomafwijkingen

83 situs inversus

84 multipele congenitale afwijkingen

85

86

87

88

89 overige congenitale afwijkingen

90 hersenbloeding

91 cephaal haematoom

92 facialis parese

93 plexus brachialis lesie

94 claviculafractuur

95 humerus fractuur

96 femur fractuur

99 andere geboortetraumata 
bijlage 4

$\mathrm{pH}$ :

geen code maar het getal, zowel arterieel als veneus

reanimatie:

neen 1

ja

2

onbekend

3

Beleid pediater:

waarbij:

I.P.P.V.

01

C.P.A.P.

02

Gärtnerbox

03

$\mathrm{O}_{2}$ in de couveuse

04

infuustherapie

05

sondevoeding

06

antibiotica

07

sepsis waarbij gekweekt

08

streptococ

09

staphylococ

10

Specifieke afwijkingen:

te coderen als L.V.R. 01 tot 99 als er nieuwe gegevens zijn ten opzichte van reeds eerder gecodeerd.

Verdere controle:

geen

kinderarts

1

andere specialist

fysiotherapie

\section{2}

3

4

Kraambed:

geen bijzonderheden

moeder overleden

overigen

Temperatuurverloop: normaal 1

1 dag verhoging minder dan $39^{\circ} \mathrm{C} \quad 2$

1 tot 3 dagen minder dan $39^{\circ} \mathrm{C}$

Septische temperatuur

Medicatie:

Antibiotica

Uterotonica

Bloed

Ferrotherapie 
verder tot

99

Lochia:

Borstvoeding:

Post partum controle:

\author{
normaal \\ riekend \\ infect bewezen met kweek \\ subinvolutie \\ curettage
}

geen

afkolven gelukt

afkolven mislukt

spontaan gelukt

spontaan gestaakt binnen 1 week

geen afwijkingen moeder

psychische afwijkingen moeder

lichamelijke afwijkingen moeder
1

2

3

4

5

1

2

3

4

5

1

2

Datum ontslag moeder: dag/maand/jaar

Eigen coderingen volgens L.V.R. formulier.

waarbij:

41 echoscopie voor $20^{e}$ week

42 opname elders

43 opname in kliniek anders dan voor partus

44 graviditeit met I.U.C.D. in situ

45 druggebruik tijdens graviditeit

46 nicotinemisbruik in de graviditeit (>20 sig./dag)

47 röntgenstralen tijdens de graviditeit

48 lues problematiek

49 gonorroe, rubella, toxoplasmose, herpes, cytomegalie

50 pyelitis

51 PAP $111 \mathrm{a}$ of meer

52 epilepsie met behandeling

53 anticoagulantia

54 weeënremming met opname

55 weeënremming zonder opname

56 bloedverlies eerste helft

57 bloedverlies tweede helft

58 hydramnion ( $>2$ liter)

59 actief $\mathrm{Rh}$-antagonisme

60 ander actief bloedgroep antagonisme

61 placenta praevia ( $20^{\circ}$ week) 
bijlage 4

62 solutio placentae

63 groeiachterstand met opname

64 diabetes gravidarum met behandeling

65 cerclage

66 hyperemesis gravidarum (met opname)

67 GTT verricht

68 amnionpunctie voor de $20^{\circ}$ week

69 amnionpunctie na de $20^{\circ}$ week

70 cardiotocografie in de graviditeit

71 oestrogenen werden bepaald

72 cardiotocografie durante partu

73 geïnfecteerde uterusinhoud voor de geboorte van het kind

74 uterusruptuur

75 pre-eclampsie met opname

76 stollingsstoornissen

77 consult andere specialist (behoudens anesthesie)

78 bloedtransfusie tijdens bevalling of kraambed

79 wanverhouding caput-bekken

80 antibiotica in het kraambed

81 anticoagulantia in het kraambed

82 sterilisatie (ook tijdens S.C.)

83 puerperaalpsychose

84 actieve lactatieremming

85 consult ander specialisme in kraambed

86 endometritis

87 mastitis

88 urineweginfectie

89 sepsis

90 embolie en/of trombose 


\section{Bijlage 5}

\section{LVR-FORMULIER TWEEDE LIJNSVERLOSKUNDE}

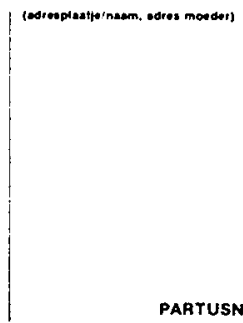

PARTUSNUMMER/MEERLING

01 zlekenhulecode 02 gyneecoloog 03 ectlecode 04 pertusnummer/meering

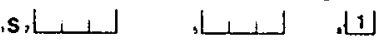

05 geboortedatum moeder tongrmangraal)

06 woonplasts (10 4 coltors posicoses)

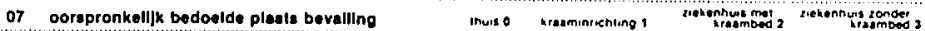

08 antal gravlditelten (Incl. dozo), wasrvan abortue (1 V/m 16 wk.) on/of EUG (1 Vm 16 wk.) en/of Mola-grav.

09 datum vorlge bevalling of partus Immaturus lang'meand/sart

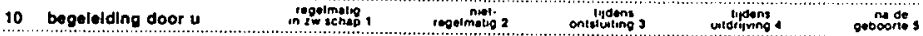

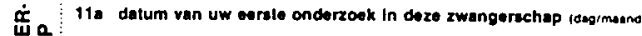

11b was bll dit onderzoek reeds sprake van intre-uterlene vruchtiood?

12 hoogste diastolleche tensle

13b zekerheld van deze datum

14. kind "aangepakt" door

14b evt. supervlste van

verloskundese 0

15. begin van de barln verlostundege 0

soonises

15b Indicalie Inleiding of prlmalre sectlo

16 wanneer braken de vilezen? idsomannd uur

D $\frac{\frac{U}{2}}{\frac{\pi}{\alpha}}$

17 medicatle voor geboorte geeno

18 begin cerale actief meeperzen (uur/munuut)

19 ligging

20a hulp bl] de baring roor orim rectio ene 151

schierhoold 0

dearss

indlcatle voor hulp of secundalre sectlo

$20 \mathrm{~b}$ indicalle voor

21

22

complications

23 geslach1

24

geboortedatum loogimannd//est

25 geboortetlydstlp furriminuul]

E $\frac{0}{\underline{z}}$

27 spgarscore inas minuten!

geboortegewicht in gramment

28 conditio

$$
\text { brend }
$$

onte peratum

29 congenitale atwl|klngen ima a sie acntectyde

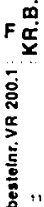

natmas o moder anerleoen :

3o verloop kraambed

32 ontslagdatum moeder loag masno h klnd mee nasr huts?

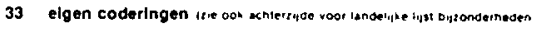

praktilknummer van vrijgevestigde verloskundige (voor de overname) sekee!

onceter 2

nemserst 1

numsent !

\section{noeno}

assutent ?

imniotoming

otocinet 1 conotito aina 2

sodshiva!

ytocine 2

......................

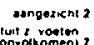

\section{.}

虫
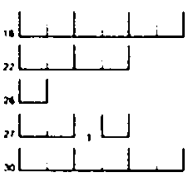
× ᄂ .L.L . ᄂ " "L , ᄂ

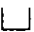
以 $\bowtie$

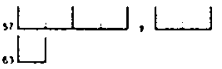
ab. I I J o.

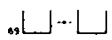
ㄴ $n \sqcup$ ,Lᄂ

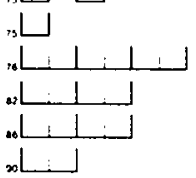
$\because$

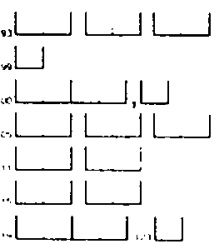




\section{Bijlage 6}

Registratieformulier voor het onderzoeksproject DUBIEUS GEBROKEN VLIEZEN.

Betreft onderzoeksproject: De diagnostiek van gebroken vliezen. Ponsplaatje van patiënte:

Afgenomen door:

- St Elisabeth Kliniek

- De Wever-Ziekenhuis

- academisch ziekenhuis Maastricht

G...P...A...

Amenorroe:........weken.......dagen

Termijn zeker: ja/nee

Klacht patiënte:

Klacht vanaf $\quad$... -.. -1986 Tijdstip: .. uren .. minuten

Vocht verkregen $\quad \ldots-. .-1986$ Tijdstip: .. uren .. minuten

Opname: Ja / Nee

s.v.p. niet invullen. code:

varentestcode:

diagnose:

klinisch: 


\section{Bijlage 7}

Onderzoeksproject: de diagnostiek van gebroken vliezen Registratievel bij vochtafname

Ponsplaatje van de patiënte

Afgenomen door

Op

Tijd

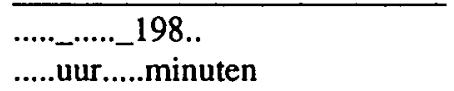

Afgenomen

vruchtwater uit cervix

$\mathrm{ja} / \mathrm{nee}$

vruchtwater uit fornix

$\mathrm{ja} / \mathrm{nee}$

vruchtwater per punctie

urine catheter

$\mathrm{ja} / \mathrm{nee}$

urine, gewassen plas

$\mathrm{ja} / \mathrm{nee}$

bloed

ja/nee

$\mathrm{ja} / \mathrm{nee}$

fluor vaginalis

$\mathrm{ja} / \mathrm{nee}$

cervixslijmprop

G....P....A....

Amenorroeduur.....weken.....dagen

s.v.p. niet invullen

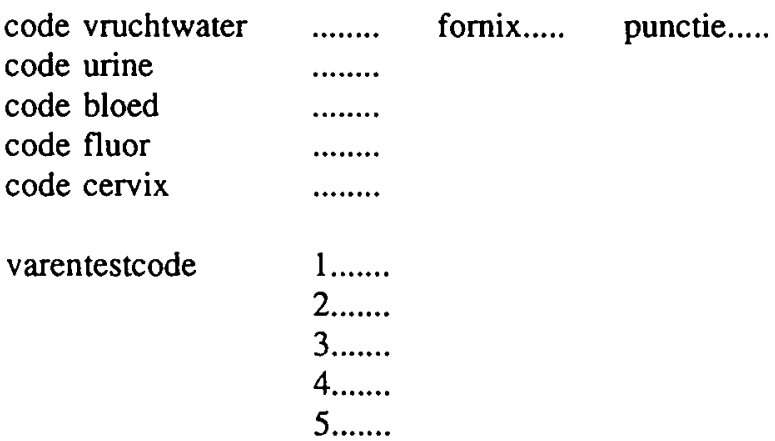




\section{Bijlage 8}

\begin{tabular}{rrrr}
$\begin{array}{r}\text { sensitivi- } \\
\text { teit }\end{array}$ & $\begin{array}{r}\text { specifici- } \\
\text { teit }\end{array}$ & $\begin{array}{r}\text { opname } \\
\text { terecht }\end{array}$ & $\begin{array}{r}\text { opname } \\
\text { ten } \\
\text { varentest }\end{array}$ \\
varentest & & onrechte \\
\hline
\end{tabular}

Gynaecologen

$\begin{array}{rrrrr}\text { 1. } & 41.0 & 86,9 & 17 & 8 \\ 2 . & 46,2 & 75,4 & 19 & 14 \\ 3 . & 59.0 & 65.6 & 28 & 21 \\ 4 . & 41.0 & 80.3 & 19 & 12 \\ 5 . & 28,2 & 77,1 & 17 & 14 \\ 6 . & 53.9 & 82.0 & 21 & 50 \\ 7 . & 53,9 & 70.5 & 20 & 48 \\ 8 . & 43,6 & 72.1 & 24 & 43 \\ 9 . & 48.7 & 72,1 & 20 & 45 \\ 10 . & 64,1 & 72,1 & 25 & 44\end{array}$

Assistenten

$\begin{array}{lllll}11 . & 38.5 & 85.3 & 15 & 52 \\ 12 . & 46.2 & 82,0 & 18 & 52 \\ 13 . & 46,2 & 70.5 & 23 & 46 \\ 14 . & 56.4 & 72,1 & 29 & 45 \\ 15 . & 53.9 & 73,8 & 26 & 45 \\ 16 . & 59.0 & 52.5 & 24 & 34 \\ 17 . & 18.0 & 88.5 & 13 & 57 \\ 18 . & 53.9 & 68.9 & 26 & 39 \\ 19 . & 51,3 & 49.2 & 28 & 38 \\ 20 . & 66.7 & 62.3 & 28 & 38\end{array}$

Co-assistenten

$\begin{array}{lllll}21 . & 64,1 & 75.4 & 27 & 46 \\ 22 . & 33,3 & 86.9 & 19 & 53 \\ 23 . & 48.7 & 67.2 & 23 & 45 \\ 24 . & 48.7 & 44.3 & 26 & 27 \\ 25 . & 53,9 & 63.9 & 28 & 40 \\ 26 . & 66.7 & 50.8 & 28 & 31 \\ 27 . & 64,1 & 62.3 & 26 & 41 \\ 28 . & 59.0 & 68,9 & 26 & 45 \\ 29 . & 64,1 & 70.5 & 27 & 43 \\ 30 . & 69.2 & 73.8 & 27 & 45\end{array}$




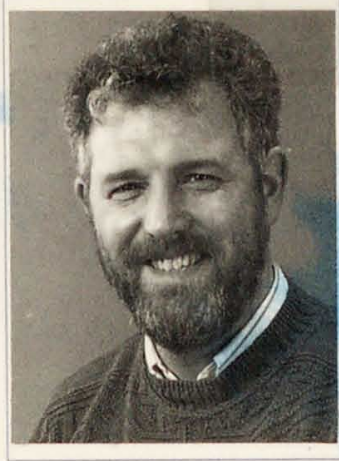

\section{Curriculum Vitae}

1 oktober 1951

Geboren te Amstenrade

\section{4-1970}

Middelbare schoolopleiding

Sint Janslyceum te

Hoensbroek, HBS-B

1970-1979

Studie Geneeskunde,

Katholieke Universiteit

Nijmegen

1980-1981

- Assistent geneeskundige niet in opleiding afdeling

Obstetrie en Gynaecologie

Ziekenhuis Sittard

- Keuringsarts Nationaal Lucht- en Ruimtevaartgeneeskundig Centrum te Soesterberg

\section{1-1988}

- Opleiding tot gynaecoloog in de Sint Elisabeth Kliniek te Heerlen

(opleider Dr. R. Omers) tot 1984, De Wever-Ziekenhuis (opleider Dr. L. Schellekens) tot 1987 en academisch ziekenhuis Maastricht (opleider Prof. Dr. J. de Haan) tot 1988

\section{8 -heden}

Lid van de staf binnen de afdeling Obstetrie en Gynaecologie van het academisch ziekenhuis Maastricht

\section{De vraagstelling van het in dit proefschrift beschreven onderzoek is drieledig:}

- Hoe vaak wordt aan de diagnose gebroken vliezen getwijfeld?

- Zijn aan die twijfel nadelen verbonden?

- Hoe die twijfel kan worden voorkomen?

\section{Kort samengevat komen de resultaten van het onderzoek er op neer dat:}

- In ongeveer 5\% van de zwangeren in Nederland aan het gebroken zijn van de vliezen wordt getwijfeld ;

- Aan het twijfelen zijn nadelen verbonden voor zowel moeder als kind;

- Het twijfelen aan de diagnose staande dan wel gebroken vliezen kan voorkomen worden met behulp van de prolactine / eiwit-ratio.

De sensitiviteit, specificiteit, positief en negatief voorspellende waarde van de test is ongeveer $90 \%$. 